\title{
APLICACIÓN DE ALTERNATIVAS TECNOLÓGICAS PARA MEJORAR EL PROCESO DE ELABORACIÓN Y LA PRESERVACIÓN DE QUESO FRESCO FUNCIONAL DE LECHE OVINA ADICIONADO CON FIBRA DIETARIA DE DISTINTOS ORÍGENES
}

Tesis de maestría presentada por:

\section{PERALTA REYES MARÍA EUGENIA}

ante la Facultad de Ingeniería de la Universidad

Nacional de La Plata para optar al grado académico de

\section{MAGÍSTER EN TECNOLOGÍA \\ E HIGIENE DE LOS ALIMENTOS}

Dirección de tesis: Dra. Marina Dello Staffolo

Octubre 2018 


\section{Agradecimientos}

Quiero agradecer a las personas e instituciones que han hecho posible el desarrollo de esta Tesis de Maestría:

- Al CIDCA por ofrecerme la oportunidad, el lugar y los medios para poder desarrollar el trabajo experimental

- A la Dra. Marina Dello Staffolo por su apoyo y dedicación

- A los docentes de la Maestría que me brindaron información de mucha utilidad, tanto para mi trabajo profesional como para el desarrollo de la tesis

- A los compañeros de la Maestría por los momentos compartidos

- Al personal del CIDCA por su colaboración en mi trabajo

- A mi familia y amigos, por el apoyo incondicional

Ma. Eugenia Peralta Reyes 


\section{Resumen}

Teniendo en cuenta la relación existente entre nutrición y salud, así como la demanda creciente de los consumidores a productos más saludables, en esta Tesis se trabajó en el desarrollo de queso fresco funcional con leche ovina adicionado con fibra dietaría de diferentes orígenes, en los cuales se aplicaron diferentes alternativas tecnológicas para lograr una mayor aceptabilidad por parte del consumidor, siempre contribuyendo a su salud y bienestar. En ese sentido, las estrategias utilizadas para la obtención de productos saludables pero sensorialmente más aceptados, fueron la homogeneización del queso fresco elaborado, la adición de diferentes tipos de fibras y la dosificación un bajo porcentaje de sal. En este trabajo se diseñaron quesos frescos con y sin homogeneizar, con y sin adición de sal y con el agregado de fibras de diferentes orígenes: fibra de bambú, fibra de trigo, inulina y psyllium. De este modo, se obtuvieron productos que además de aportar fibra a la dieta diaria y poseer valores de sodio bajo, presentan un mayor contenido de proteínas que los productos comerciales, que coincide con el hecho de que el contenido proteico en la leche de oveja es superior al de la leche de vaca. De todas las elaboraciones se determinó el rendimiento quesero, y los productos desarrollados fueron caracterizados a través de su composición centesimal y valor calórico. A su vez, se evaluó la microestructura y la reología de los diferentes quesos desarrollados, completando el estudio de los mismos con un análisis sensorial de aceptabilidad general, para determinar si las alternativas tecnológicas aplicadas influenciaron positivamente en la percepción del consumidor. Además, se realizó el seguimiento durante su almacenamiento congelado, en envases de polietileno y película semipermeable al oxígeno, evaluando $\mathrm{pH}$, suero liberado, microestructura, textura y oxidación de lípidos. Se pudo concluir que es posible elaborar quesos frescos untables de leche ovina funcionales con inulina, fibra de trigo o fibra de bambú con características muy saludables desde el punto de vista nutricional. De igual modo, la adición de $0.3 \%$ de sal, el proceso de homogeneizado y el almacenamiento congelado fueron alternativas tecnológicas adecuadas para elevar y preservar la calidad de los quesos frescos untables desarrollados. 


\section{INDICE GENERAL}

Capítulo 1. Introducción 1

1.1. Alimentos funcionales.................................................... $\quad 2$

1.2. Fibra dietaria........................................................... 4

1.3. Desarrollo de alimentos funcionales........................................... $\quad 9$

1.3.1. Elección del producto para desarrollar un alimento funcional...... 9

1.4. Evaluación de la calidad del producto desarrollado....................... 16

1.4.1. Evaluación de la microestructura del producto................... $\quad 16$

1.4.2. Evaluación de la textura............................................ 16

1.4.3. Evaluación sensorial............................................. 22

1.5. Métodos de conservación de los quesos frescos............................ 23

1.6. Objetivos del trabajo de tesis......................................... 25

1.6.1. Objetivo general.................................................. 25

1.6.2. Objetivos específicos............................................. $\quad 26$

Capítulo 2. Materiales y Métodos 27

2.1. Materias primas empleadas y sus características......................... 28

2.1.1. Leche ovina.................................................... $\quad 28$

2.1.2. Microorganismos empleados en la manufactura del queso............ 28

2.1.3 Fibra dietaria de distintos orígenes................................. 28

2.1.3.1 Determinación de la distribución del tamaño de partícula de

las fibras empleadas.............................................................. 30 
2.2. Proceso de elaboración de queso fresco untable de leche ovina funcional adicionado con fibra dietaria de distintos orígenes......................... 30

2.2.1. Determinación de la fuerza de cuajado de la leche.................. 30

2.2.2. Manufactura del queso............................................. 31

2.2.3. Rendimiento quesero..................................................... $\quad 33$

2.2.4. Desarrollo de las formulaciones de quesos fucionales................ 33

2.3. Ensayos efectuados en los quesos funcionales.......................... $\quad 35$

2.3.1. Evaluación del producto terminado................................... 35

2.3.1.1. Medición de pH............................................. 35

2.3.1.2. Composición centesimal...................................... 35

2.3.1.2.1. Determinación de humedad.............................. 35

2.3.1.2.2. Determinación de cenizas............................... 36

2.3.1.2.3. Determinación de materia grasa...................... 36

2.3.1.2.4. Determinación de proteínas............................... 37

2.3.1.2.5. Determinación de hidratos de carbono................. 40

2.3.1.3. Determinación del contenido de sodio........................ 41

2.3.1.4. Determinación del contenido de calcio......................... 42

2.3.1.5. Determinación de la composición de ácidos grasos.............. 43

2.3.1.6. Determinación del valor calórico.............................. 44

2.3.1.7. Evaluación de la microestructura............................. 44

2.3.1.8. Determinación de las propiedades mecánicas de los quesos 45 elaborados 
2.3.1.8.1. Ensayo a bajas deformaciones........................ 48

2.3.1.8.2. Ensayo a grandes deformaciones...................... 51

2.3.1.9. Evaluación sensorial de aceptabilidad general.................. 53

2.3.1.10. Análisis estadístico....................................... 55

2.3.2. Evaluación de la calidad de los quesos funcionales elaborados durante el 55

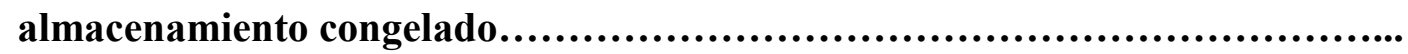

2.3.2.1. Medición de pH................................................. $\quad 56$

2.3.2.2. Cuantificación del suero liberado................................ $\quad 56$

2.3.2.3. Estudio de la microestructura..................................... $\quad 57$

2.3.2.4. Evaluación instrumental de la textura............................ 57

2.3.2.5. Determinación de la estabilidad de los lípidos durante el almacenamiento...................................................... 57

2.3.2.6. Evaluación sensorial de aceptabilidad general..................... $\quad 60$

2.3.2.7. Análisis estadístico............................................... $\quad 60$

Capítulo 3. Resultados y discusión

3.1. Evaluación del producto terminado.................................. $\quad 62$

3.1.1. Rendimiento quesero.............................................. $\quad 62$

3.1.2. Composición centesimal................................................. $\quad 64$

3.1.3. Determinación de sodio............................................ 67

3.1.4. Determinación de calcio.......................................... $\quad 68$

3.1.5. Determinación de la compasión de ácidos grasos....................... 68

3.1.6. Determinación del valor calórico..................................... 71 
3.1.7. Microestructura y $\mathrm{pH}$ de los quesos elaborados.....................

3.1.8. Determinación de las propiedades mecánicas de los quesos

elaborados.

3.1.8.1. Ensayos a bajas deformaciones............................. 82

3.1.8.2. Ensayos a grandes deformaciones............................ 88

3.1.9. Análisis sensorial de aceptabilidad general......................... $\quad 92$

3.2. Evaluación de la calidad de los quesos funcionales elaborados durante el $\quad 96$

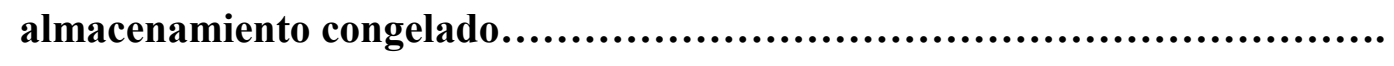

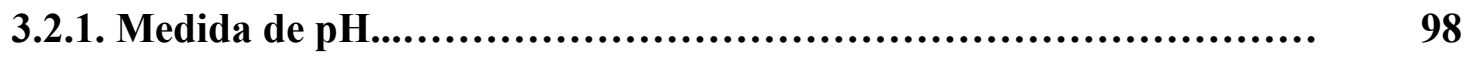

3.2.2. Cuantificación del suero liberado........................................ $\quad 99$

3.2.3. Estudio de la microestructura luego del almacenamiento congelado.. $\quad 102$

3.2.4. Evaluación instrumental de la textura.............................. 103

3.2.5. Determinación de la estabilidad de los lípidos durante el 105 almacenamiento.

3.2.6. Evaluación sensorial de aceptabilidad

109

Capítulo 4. Conclusiones....................................... 111

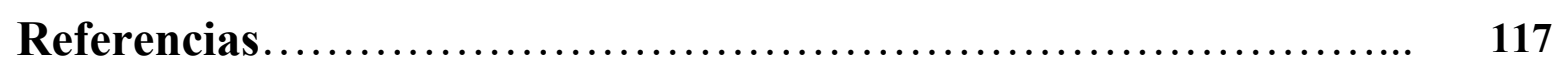


CAPÍTULO 1

\section{INTRODUCCIÓN}


En la actualidad, el concepto de nutrición ha evolucionado notablemente gracias a la investigación constante y al crecimiento de la información disponible. La prevención de enfermedades crónicas no transmisibles se ha convertido en el foco de interés tanto desde la Salud Pública como desde la investigación y la tecnología. En este marco nacen los alimentos funcionales, diseñados especialmente con componentes conocidos como bioactivos que pueden promover un efecto positivo en la salud más allá de su valor nutritivo tradicional (Korhonen, 2009; Park y Oh, 2010).

\subsection{Alimentos funcionales}

Los consumidores, conscientes de sus necesidades buscan en el mercado aquellos productos que contribuyan a su salud y bienestar. Siguiendo esta tendencia, reciben abundante información sobre las propiedades saludables de los alimentos, en especial de aquellos alimentos que ejercen una acción beneficiosa sobre algunos procesos físiológicos y/o reducen el riesgo de padecer una enfermedad. Estos alimentos que promueven la salud han sido denominados alimentos funcionales (AF) y las empresas que los producen presentan una rápida expansión mundial (Olagnero y col., 2007). En 2013, los ingresos globales fueron de \$ 175 mil millones, y para 2015 se proyectó un incremento de \$55 mil millones (Research \& Markets, 2013). El crecimiento se debió principalmente a la demanda de bebidas energéticas y productos lácteos fortificados. En los mercados actuales, la innovación tecnológica representa una estrategia competitiva fundamental para el liderazgo; y en la categoría de alimentos funcionales, la mayor innovación se produce en los productos lácteos. Los mismos constituyen una fuente natural valiosa de numerosos compuestos bioactivos y son además muy aceptados como vehículos de otros compuestos beneficiosos agregados, provenientes de distintas fuentes naturales (Augustin y Sanguansri, 2015).

Los alimentos funcionales son alimentos que contienen componentes bioactivos: compuestos químicos que pueden estar presentes naturalmente, o bien formarse o agregarse durante el procesamiento de los alimentos, y que ejercen funciones bioquímicas/fisiológicas específicas cuando son consumidos por los seres humanos. Dichas funciones pueden ser 
contribuir a la mantención de la salud y bienestar, a la disminución del riesgo de enfermar, o ambas cosas (Olagnero y col., 2007, Korhonen, 2009; Park y Oh, 2010). Deben ser alimentos manufacturados a partir de ingredientes naturales, se deben consumir como parte de la dieta diaria y deben cumplir un papel específico en la fisiología del ser humano (Day y col., 2009). El concepto de Alimentos Funcionales surge como un instrumento para mejorar la salud de la población y reducir el riesgo de ciertas enfermedades, a partir de la mayor esperanza de vida y del crecimiento de las enfermedades crónicas y sus consecuencias sobre la salud pública. Es importante resaltar que un alimento funcional debe seguir siendo un alimento y ejercer sus acciones benéficas en las cantidades habitualmente consumidas en la dieta (Olagnero y col., 2007).

Como los beneficios para la salud que ofrecen los alimentos funcionales se determinan por los ingredientes usados en su formulación, la legislación alimentaria japonesa, que fue la primera en el mundo en considerar este tipo de alimentos en la década de 1980, reconoció 10 tipos principales de ingredientes que favorecen la salud: 1) Fibra dietaria; 2) Polioles; 3) Péptidos y proteínas; 4) Glúcidos; 5) Alcoholes; 6) Isoprenoides y vitaminas; 7) Colinas; 8) Bacterias Lácticas; 9) Minerales; 10) Ácidos grasos poliinsaturados. El concepto, se ha esparcido desde entonces, a través de todo el mundo y se ha depurado su definición y legislación (Vasconcellos, 2001).

Es importante remarcar que los efectos de los alimentos funcionales pueden ser divididos en efectos funcionales y efectos sobre la salud del individuo. Los efectos funcionales, como la modulación metabólica, la atenuación del colesterol, el equilibrio de la flora intestinal, la modulación inmunológica, la acción antioxidante, la activación de la citocromo oxidasa, etc., son acciones metabólicas que pueden ponerse en evidencia, y hay diversos trabajos científicos que estudian este tema (Shahidi, 2004). Los efectos sobre la salud del individuo, relacionados con prevención, cura y reducción de enfermedades, requieren el estudio en el tiempo con pacientes que es más costoso y laborioso. Sin embargo, cada vez es más mayor el número de trabajos científicos que correlaciona las funciones de varios componentes alimenticios (nutrientes y no nutrientes) con la prevención y el tratamiento de enfermedades específicas (Rinaldi y Arechederra, 2001; Kruger y Mann, 2003). 


\subsubsection{Fibra dietaria}

La Comisión del Codex Alimentarius adoptó una nueva definición de la fibra en julio de 2009, destinada a armonizar el uso de la palabra en todo el mundo. Se describe a la fibra como elementos no hidrolizables por las enzimas endógenas en el intestino delgado (indigestibilidad), y que tienen efectos fisiológicos beneficiosos para la salud. Las fibras dietarias son polímeros de carbohidratos con diez o más unidades monoméricas y que pertenecen a una de las siguientes tres categorías: polímeros comestibles de hidratos de carbono de origen natural en los alimentos, polímeros de carbohidratos que han sido obtenidos de materia prima alimentaria por medios físicos, enzimáticos o químicos y carbohidratos poliméricos sintéticos (Cummings y col., 2009; Phillips y Cui, 2011).

El Código Alimentario Argentino modificó por resolución del 14 de marzo de 2007, el artículo 1339, incluyendo a los alimentos adicionados con fibra dentro del grupo de alimentos que satisfacen necesidades alimentarias específicas de determinados grupos de personas sanas. Además, en el artículo 1385 se define a la fibra de la siguiente manera: se entiende por Fibra Alimentaria a cualquier material comestible que no sea hidrolizado por las enzimas endógenas del tracto digestivo humano. Incluye polisacáridos no almidón, pectinas, almidón resistente, inulina, oligofructosa, polidextrosa, maltodextrinas resistentes, fructooligosacáridos (FOS), galactooligosacáridos (GOS), transgalactooligosacáridos (TOS), y todos los que en el futuro incorpore la Autoridad Sanitaria Nacional.

El consumo de fibra dietaria en los países occidentales se estima actualmente entre 16,3-43,4 g por persona por día (Green, 2000). De acuerdo con las recomendaciones actuales, el promedio diario requerido de fibra dietaria es de 25 g por día para las mujeres menores de 50 años, 21 g por día para las mujeres mayores de 50 años; 38 g por día para los hombres menores de 50 años, y 30 g por día para los hombres mayores de 50 años (Food and Nutrition Board, Institute of Medicine, 2001). Es por eso que el desarrollo de alimentos fortificados o adicionados con fibras ayudaría a los consumidores a satisfacer tales recomendaciones.

La fibra se agrega a los alimentos con el propósito de influir positivamente en funciones biológicas específicas, mejorar el estado general de salud y/o reducir el riesgo de padecer distintas enfermedades (Rodríguez y col., 2006). Debido a que la fibra no se 
hidroliza, ni se digiere ni se absorbe en el intestino delgado, contribuye a aumentar el volumen fecal, estimular la fermentación en el colon y reducir los niveles de glucosa y colesterol en sangre (Elleuch y col., 2011). Además, el consumo de fibra disminuye la concentración sérica de lípidos, disminuye la presión arterial, mejora el nivel de glucemia en la diabetes, ayuda en la pérdida de peso y mejora la función inmune (Anderson y col., 2009). Teniendo en cuenta lo anterior, el consumo de fibra proporciona varios beneficios para la salud como reducir el riesgo de enfermedades coronarias, accidentes cerebrovasculares, hipertensión, diabetes, obesidad, ciertos desórdenes gastrointestinales y ayuda a prevenir el cáncer (Barclay y col., 2008; Brownlee, 2011; Cho y col., 2007; Cummings y col., 2009; Dahm y col., 2010; Eshak y col., 2010; Code of Federal Regulations, 2010; Kaczmarczyka y col., 2012; Lairon y col., 2007; Lattimer y col., 2010; Molist y col., 2009; Phillips y Cui, 2011; Phillips, 2005; Sluijs y col., 2010; Wang y col., 2007).

La fibra dietaria fue inicialmente promovida por sus propiedades saludables para el cuerpo humano. Sin embargo, también tiene propiedades tecnológicas que pueden ser aprovechadas en la formulación de alimentos ya que tiene la capacidad de modificar textura, estabilizar los alimentos con altos contenidos de grasa y emulsiones, y aumentar la vida útil (Thebaudin y col., 1997; Elleuch y col., 2011). Además, las fibras modifican la viscosidad de soluciones acuosas. Generalmente, a mayor peso molecular o largo de las cadenas de las fibras, aumenta la viscosidad de la solución. La capacidad de formar geles también es un importante atributo de algunas fibras. El gel retiene agua y otros compuestos que estén en solución para constituir una estructura tridimensional firme (Gibson y Williams, 2000).

Existe varias clasificaciones para la fibra dietaria pero la más utilizada, es aquella que la divide en soluble e insoluble. La fibra soluble incluye sustancias pécticas, gomas, mucilagos y hemicelulosas (Beta-glucanos), mientras que la celulosa, y la lignina se incluyen en la fracción insoluble. La fibra soluble se caracteriza por su capacidad para aumentar la viscosidad, reducir la respuesta glicémica y el colesterol plasmático. Las fibras insolubles se caracterizan por su porosidad, su baja densidad, su capacidad de retener agua en su matriz estructural formando mezclas de baja viscosidad y por su capacidad de aumentar el volumen fecal y disminuir el tiempo total del tránsito intestinal. 
La fibra dietaria proveniente de los vegetales incluye oligosacáridos, inulina y polisacáridos. Dentro de éstos últimos se encuentran: celulosa, hemicelulosas, sustancias pécticas, gomas, almidón resistente, que pueden estar asociados con la lignina y otros componentes que no sean carbohidratos (por ejemplo, los polifenoles, ceras, saponinas, cutina, fitatos y proteínas). Los cereales son la principal fuente de celulosa, lignina y hemicelulosas, mientras que las frutas y verduras son las fuentes primarias de oligosacáridos, pectina, gomas y mucílagos (Elleuch y col., 2011). Cada polisacárido se caracteriza por sus residuos de azúcar y por la naturaleza de la unión entre ellos.

La estructura básica de la celulosa está constituida por dos moléculas de glucosa unidas con enlace $\beta$-1-4-glucopiranosil-glucopiranosa sin ramificaciones (Fig. 1.1a). La celulosa sólida forma una estructura tridimensional polimórfica. Posee áreas cristalinas que se alternan con áreas amorfas. La proporción en que éstas se encuentran depende de la materia prima (origen vegetal, procesamiento, etc.). Las áreas amorfas son más fácilmente hidrolizables, debido a que tienen más grupos hidroxilos disponibles que las áreas cristalinas. Las características funcionales de la celulosa dependen de la relación entre componentes amorfos y cristalinos.

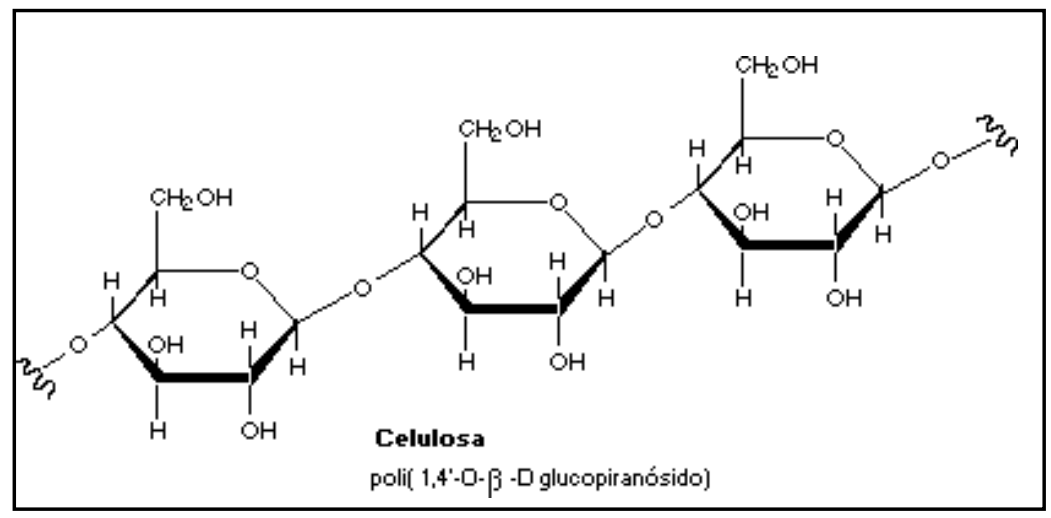

Figura 1.1 Estructura química de la celulosa

Las hemicelulosas, son un grupo heterogéneo de polisacáridos que contienen varios azúcares distintos en su cadena principal y otros en sus cadenas laterales (Figura 1.2 a). Exhiben una gran solubilidad, que está asociada, con un alto grado de ramificaciones (Olds Schneeman, 1986). La lignina purificada, es un polímero complejo el cual contiene unidades de fenilpropano derivadas de sinapil, coniferil, cinamil y cumaril alcoholes (Figura 1.2 b). 
Introducción

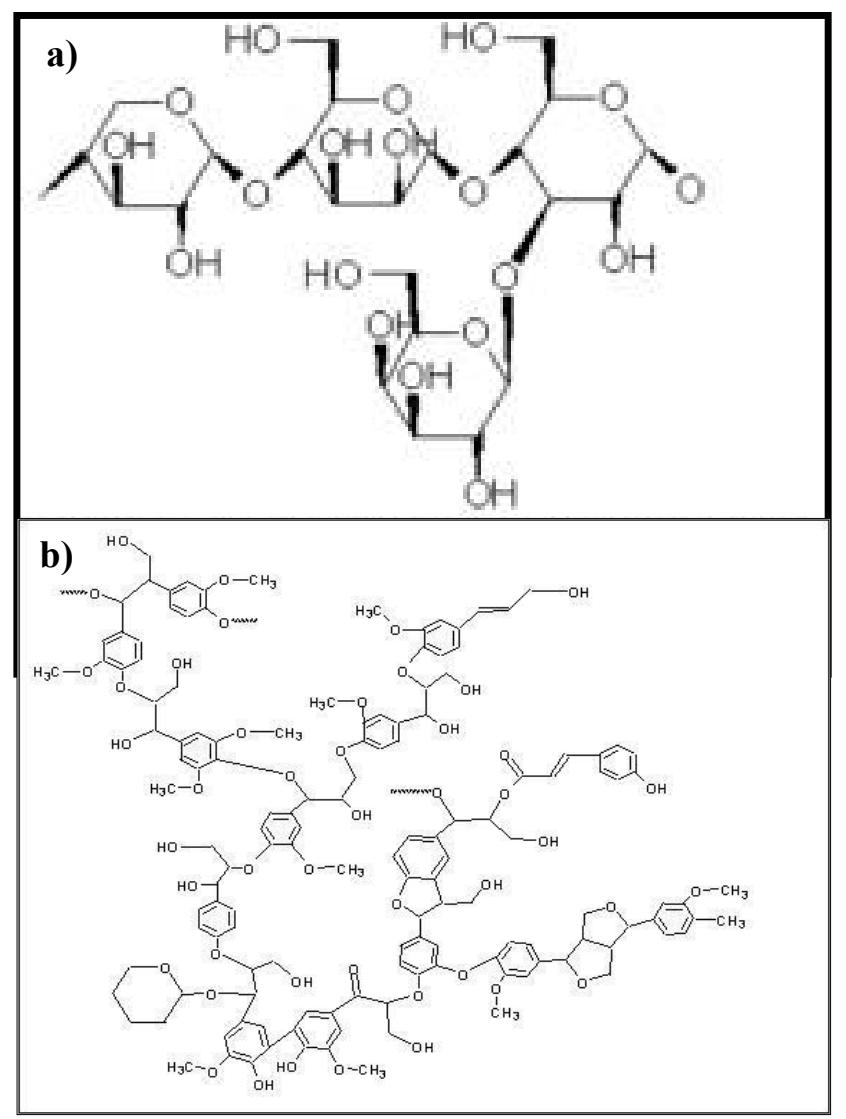

Figura 1.2 Estructura química de a) hemicelulosa típica y b) lignina.

Los oligosacáridos resistentes (OR) también llamados oligosacáridos no digeribles (OND), tales como los fructanos, se caracterizan por un grado de polimerización relativamente bajo. La definición estricta de un oligosacárido es una cadena de 3 a 10 monómeros (Englyst y col. 1995). También integran este grupo los galactooligosacáridos (GOS) y los transgalactooligosacáridos (TOS o TGOS). Los GOS son producidos a partir de la lactosa por la acción transglicosilativa de la $\beta$-galactosidasa. Ellos consisten en una cadena de residuos galactosilo con uniones $\beta-1,6$ con una glucosa terminal unida por enlace $\alpha-1,4$ (Southgate, 1976 y 1982).

La inulina es un carbohidrato de reserva de muchas plantas. Es un polímero lineal soluble. Está constituida por entre 2 y 60 unidades de fructosa unidas por enlaces $\beta-2-1$ con una molécula de glucosa en el extremo unida a la fructosa por enlaces $\alpha-1-2$ (Figura 1.3). La inulina está presente en una gran variedad de vegetales como: cebollas, espárrago, achicoria, alcaucil, ajo, trigo, cebada, centeno y banana entre otros. Muchas plantas que 
contienen inulina forman parte de la dieta básica occidental desde hace mucho tiempo, siendo la cebolla la más consumida entre ellas.

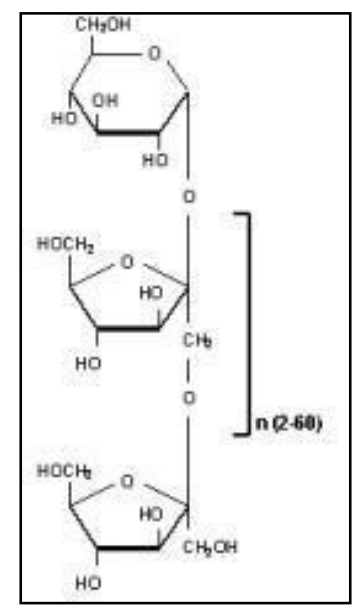

Figura 1.3 Molécula de inulina

Se obtiene a partir de la materia seca del vegetal y es extraída mediante un proceso químico. Se presenta como un polvo blanco, amorfo, higroscópico, con olor y sabor neutros (Silva, 1996). La inulina tiene la capacidad de aumentar la viscosidad de soluciones acuosas a medida que se aumenta su concentración. Para formar gel, la inulina tiene que estar en una concentración de 30\% en solución acuosa. El gel de inulina es muy cremoso y se asemeja a la textura de la materia grasa. La disponibilidad de agua es el factor que más afecta las características del gel. Debido a su grado de polimerización, la inulina tiene la habilidad de formar microcristales cuando se mezcla con agua o leche. Estos microcristales no son percibidos en la boca pero se integran para formar una textura finamente cremosa que promueven una sensación semejante a la materia grasa. Por lo tanto, es usada con éxito en varios productos como sustituto de la fase grasa (De Oliveira Hauly y Moscatto, 2002). Tiene una amplia aplicación en la industria alimenticia gracias a su gran versatilidad, no influye en el sabor o en la apariencia visual del producto. La inulina es muy resistente al calor, inodora e hipoalergénica. Reemplaza muy bien azúcares y materia grasa y además es un agente texturizante. Tiene propiedades prebióticas.

También existen fibras provenientes del reino animal como quitina y quitosano que se extraen de hongos, levaduras e invertebrados (Tungland y Meyer, 2002). La quitina está contenida en los exoesqueletos de los crustáceos y plumas de calamar. El quitosano se produce por desacetilación de la molécula de quitina. Su estructura molecular es similar a la 
de la celulosa de las plantas ya que posee enlaces $\beta-1,4$ entre sus monómeros. Difiere de ésta última en que es un heteropolisacárido formado por las unidades de D-glucosamina que se encuentra desacetilada y $\mathrm{N}$-acetilglucosamina que está acetilada (Elleuch, 2011).

\subsection{Desarrollo de alimentos funcionales}

El diseño y desarrollo de alimentos funcionales no solo debe hacerse teniendo en cuenta las propiedades nutricionales deseadas, sino también propiedades sensoriales como el color, textura y sabor. El aspecto y las propiedades sensoriales son los atributos más importantes para el consumidor, incluso por encima de los valores nutricionales, que deciden la adquisición del alimento (Day y col., 2009). A su vez, el aspecto y las propiedades sensoriales dependen de la formulación química del alimento y de las características fisicoquímicas que deriven de esta formulación. Por lo tanto, es muy importante la elección del tipo de producto para desarrollar un alimento funcional y la evaluación de su textura, sabor y color para satisfacer a los consumidores y lograr una buena inserción en el mercado.

\subsubsection{Elección del producto para desarrollar un alimento funcional}

De todos los tipos de alimentos disponibles, el queso es un excelente producto base para desarrollar un alimento funcional ya que es un producto que responde perfectamente a las modernas tendencias del consumo: es un alimento saludable y completo (proteínas, un nivel de grasas aceptable, calcio, fósforo, vitaminas A, B y D), conveniente (adecuado para múltiples usos) y atractivo (por su sabor).

El queso se define como un producto fresco o madurado, obtenido del drenaje del suero luego de la coagulación de las caseínas. Las caseínas se pueden coagular mediante la producción de ácidos por microorganismos seleccionados, mediante la utilización de enzimas o por la adición de acidulantes alimenticios (Walther y col., 2008).

Los quesos, están formados por una estructura primaria de proteínas que contiene atrapada en su interior la materia grasa. La grasa afecta indirectamente la relación aguaproteína y regula la firmeza y la elasticidad de los quesos mediante el aumento de retención 
de humedad de la cuajada (Küçüköner y Haque, 2003). La textura de los quesos con alto contenido de grasa generalmente es más aceptada que los quesos con bajo contenido de grasa (Gunasekaran y Ak, 2003).

Existen en el mercado mundial muchos tipos de quesos y se clasifican, en líneas generales, según el contenido de humedad en: duros (entre 27 y 35\% de agua), semiduros (entre 36 y 44\% de agua) y frescos (entre 45 y $80 \%$ de agua). Además pueden clasificarse según el origen de la materia prima (leche) empleada. El Código Alimentario Argentino los agrupa teniendo en cuenta las siguientes características:

A) El contenido de materia grasa del extracto seco en porcentaje:

- Extra graso o Doble crema: cuando contengan no menos del 60,0\%.

- Grasos: cuando contengan entre 45,0 y $59,9 \%$.

- Semigrasos: cuando contengan entre 25,0 y 44,9\%.

- Magros: cuando contengan entre 10,0 y $24,9 \%$.

- Descremados: cuando contengan menos de 10,0\%.

B) El contenido de humedad, en porcentaje:

- Quesos de baja humedad (generalmente conocidos como de pasta dura): humedad hasta $35,9 \%$.

- Quesos de mediana humedad (generalmente conocidos como de pasta semidura): humedad entre 36,0 y $45,9 \%$.

- Quesos de alta humedad (generalmente conocidos como de pasta blanda o macíos): humedad entre 46,0 y $54,9 \%$.

- Quesos de muy alta humedad (generalmente conocidos como de pasta muy blanda o mole): humedad no menor a 55,0\%.

Los quesos de muy alta humedad se clasifican a su vez, de acuerdo a si han recibido o no, tratamiento térmico luego de la fermentación, en:

- Quesos de muy alta humedad tratados térmicamente

-Quesos de muy alta humedad

Las variedades de queso en el mercado son enormes, lo que se refleja también en la variabilidad en la composición química de los diferentes tipos de queso (Tabla 1.1) y por lo tanto, en las propiedades fisicoquímicas que poseen. Los quesos de pasta muy blanda o frescos como se los denomina en la literatura inglesa, son los quesos más consumidos en 
América Latina (Gunasekaran y Ak, 2003) y en especial en Argentina (S.A.G.P. y A., 2009), por lo tanto, son una buena elección para introducir aditivos beneficiosos para la salud. Entre las causas de este último comportamiento se mencionan: su menor precio y su adaptabilidad a las mayores exigencias dietéticas y nutricionales. La inmensa gama de variedades y aplicaciones posibles, que van desde el consumo directo hasta la utilización como ingrediente de las comidas más sofisticadas, lo transforman en uno de los productos más versátiles y de mayor difusión a escala global.

Tabla 1.1 Composición química centesimal (en g\%) de quesos agrupados según su contenido de humedad. Fuente: Sieber R., 2001.

\begin{tabular}{ccccc}
\hline Humedad & Grasa & Proteínas & Minerales & Lactosa \\
\hline & g/100g de producto &
\end{tabular}

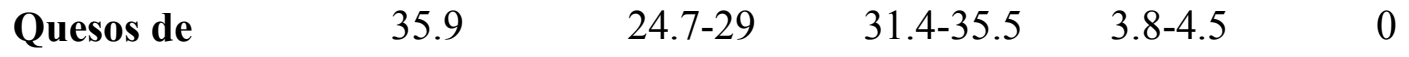

pasta dura

$\begin{array}{llllll}\text { Quesos de } & 36-45.9 & 24-26.4 & 27.9-31.7 & 1.9-4 & 0\end{array}$

pasta semidura

$\begin{array}{llllll}\text { Quesos de } & 46.0-54.9 & 20.3-33.8 & 11.4-25.2 & 1.8-5 & 0\end{array}$

pasta

blanda(macíos)

$\begin{array}{llllll}\text { Quesos de } & \geq 55 & 7-32.3 & 7.9-23.2 & 1.4-3.9 & 2.2-3.5\end{array}$

pasta muy

blanda(mole)

Entre los quesos de pasta muy blanda se encuentran aquellos producidos por la coagulación de la leche, crema o suero mediante acidificación lenta o combinación de acidificación y acción enzimática, con o sin tratamiento térmico, los cuales están listos para consumir, una vez que finalizan las operaciones de manufactura y no tienen una etapa de 
maduración. Los quesos frescos son aquellos en los que la elaboración consiste únicamente en cuajar y deshidratar la leche, a los cuales no se les aplican técnicas de conservación adicionales, por lo que su vida útil es relativamente corta en comparación con otros tipos de quesos. A su vez, el hecho de procesar la leche en menor medida hace que tengan sabores suaves y texturas poco consistentes (Gráfico 1.1).

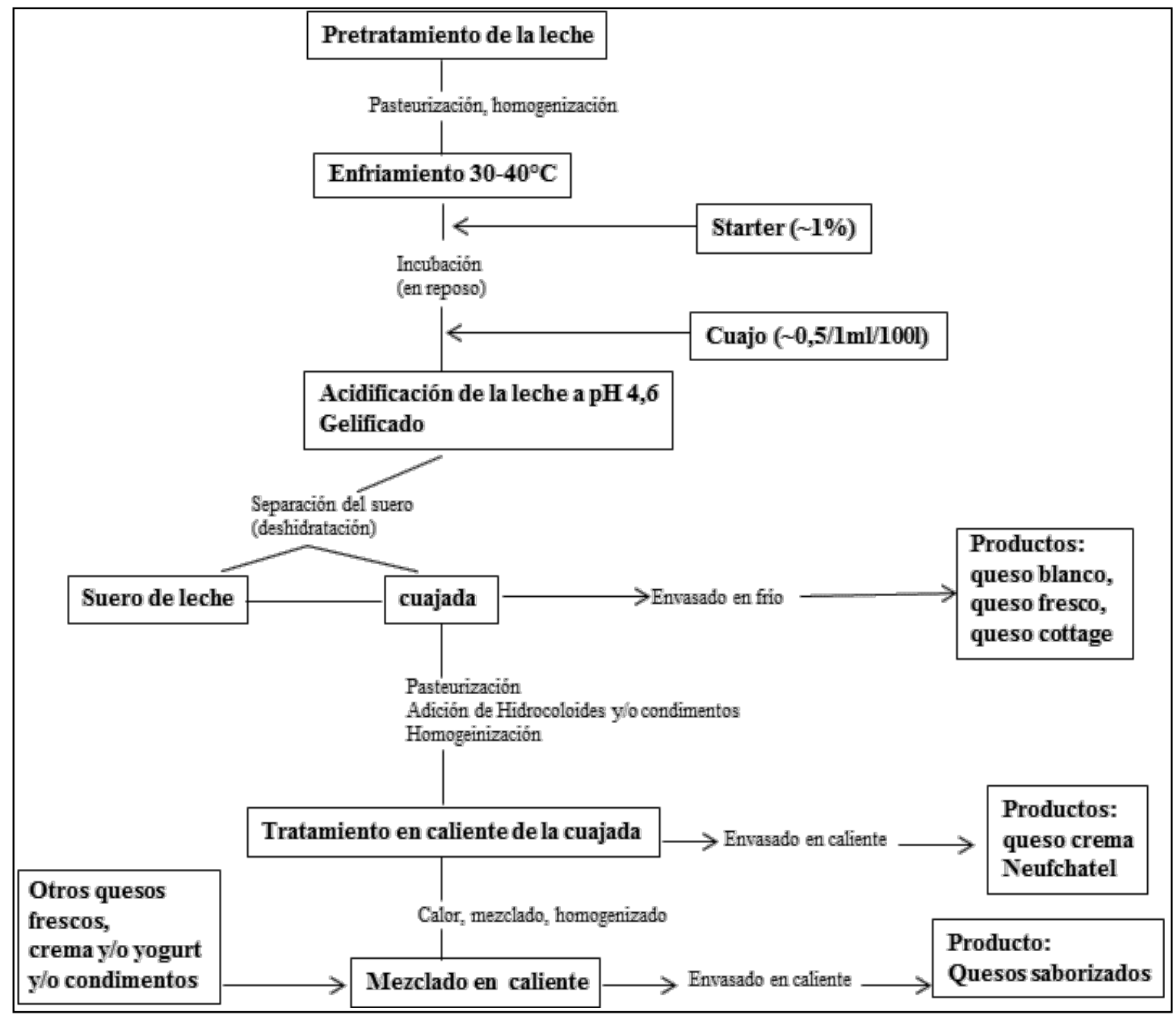

Gráfico 1.1 Esquema de producción de queso de pasta muy blanda

En este tipo de quesos la coagulación ocurre cerca del punto isoeléctrico de la caseína, es decir pH 4,6, produciéndose una coagulación más láctica y enzimática, que produce además de una textura suave, un sabor láctico con notas de acetilo y acetaldehído muy particular y apreciado. En este tipo de elaboraciones, también se utiliza una pequeña cantidad de cuajo como en el queso blanco argentino y el "cottage" para dar firmeza al 
coagulo y minimizar la pérdida de caseína en la etapa de separación del suero (Guinee y col., 1999). La elaboración de estos quesos generalmente involucra tratamientos previos a la leche, acidificación lenta mediante los cultivos utilizados, gelificación, separación del suero y en algunos tipos de quesos se realiza además, un tratamiento térmico a la cuajada y la adición de otros ingredientes (Gráfico 1.1).

Por lo tanto y dependiendo de las etapas de elaboración que tengan, pertenecen a este grupo los siguientes productos que se pueden encontrar en el mercado argentino: queso blanco argentino (entero, semimagro ó descremado), ricotta (entera, semimagra ó descremada), queso neufchatel, mascarpone argentino, queso de crema, petit suisse argentino.

En cuanto al tipo de leche empleado en la elaboración de quesos, las leches no tradicionales, como la leche de oveja y cabra, vienen despertando un creciente interés en Argentina ya que se las considera como productos gourmet. Sin embargo, como no existe la tradición de consumirlas fluidas, el $70 \%$ del volumen producido es destinado a la elaboración de queso. Estas leches presentan un denominador común: en general están asociadas a economías regionales, a pequeñas escalas de producción, y a la elaboración artesanal de productos de elevado valor agregado.

En particular, la leche de oveja constituye un excelente alimento, por su elevado contenido en proteína, materia grasa y minerales $(\mathrm{Ca}, \mathrm{Mg}, \mathrm{Mn}, \mathrm{Fe}, \mathrm{P}, \mathrm{y} \mathrm{Zn}$ ) ya que permite obtener, con iguales cantidades de leche, entre 1,5 y 2 veces más cantidad de queso que con la leche de vaca (Sosa y col., 2001; Balthazar, 2017). Es decir, que la leche de oveja muestra una superioridad en su composición química con respecto a la leche de vaca y cabra (Tabla 1.2).

Los contenidos de proteína, calcio, hierro, magnesio, zinc, tiamina, riboflavina, vitamina B6, vitamina B12, vitamina $\mathrm{D}$, ácidos grasos de cadena media, monoinsaturados, ácido linolénico y aminoácidos esenciales son más elevados (Haenlein, 2001; Balthazar, 2017). Estos contenidos pueden variar dependiendo de la temporada, la raza, la dieta y la condición del animal (Pandya y Ghodke, 2006). Si bien, la cantidad de materia grasa es superior en la leche de oveja con respecto a la de vaca, ésta tiene importantes beneficios para la salud. Los glóbulos de grasa en la leche de oveja son más pequeños que los de la leche de vaca contribuyendo a aumentar su digestibilidad, y su homogeneidad, además de 
prevenir el aumento del colesterol sanguíneo (Park y col., 2007; Balthazar, 2017).

Tabla 1.2 Composición media de nutrientes básicos en leche de cabra, oveja, vaca y humanos (Park y col., 2007).

\begin{tabular}{lcccc}
\hline \multicolumn{1}{c}{ Composición } & cabra & oveja & vaca & Humano \\
\hline Grasa (\%) & 3.8 & 7.9 & 3.6 & 4.0 \\
Solidos no grasos (\%) & 8.9 & 12.0 & 9.0 & 8.9 \\
Lactosa (\%) & 4.1 & 4.9 & 4.7 & 6.9 \\
Proteína (\%) & 3.4 & 6.2 & 3.2 & 1.2 \\
Caseína (\%) & 2.4 & 4.2 & 2.6 & 0.4 \\
Albumina, globulina (\%) & 0.6 & 1.0 & 0.6 & 0.7 \\
N no proteico (\%) & 0.4 & 0.8 & 0.2 & 0.5 \\
Ceniza (\%) & 0.8 & 0.9 & 0.7 & 0.3 \\
Calorías /100ml & 70 & 105 & 69 & 68 \\
\hline
\end{tabular}

El $45 \%$ de los ácidos grasos presentes en la leche de oveja son mono o poliinsaturados, encontrándose entre ellos dos isómeros del ácido linoleico conjugado (CLA): cis-9, trans-11 (ácido ruménico) y trans-10, cis-12, los cuales han demostrado tener efectos beneficiosos en modelos animales. El ácido ruménico tiene efecto anticarcinogénico, inmunomodulador y antiesteroesclerótico, mientras que el trans-10, cis12 mejora las propiedades de la masa corporal magra. El isómero cis-9, trans-11 es aproximadamente un 80-90\% del CLA en la fase grasa de la leche. Este isómero es producido como un intermediario durante la biohidrogenación de los ácidos grasos poliinsaturados, especialmente el ácido linoleico y el a linolénico (cis-9, cis-12, cis-15 C18:3) y del ácido vaccenico (trans-11 C18:1) en la glándula mamaria mediante la D9 desaturasa. El procesamiento de la leche para hacer queso parece no tener efectos en la concentración final de CLA, el contenido depende de los niveles de CLA en la leche sin procesar (Prandini y col., 2011).

La leche de oveja, contiene también una gran proporción de ácidos grasos de cadena corta y media que se sabe que aumentan la absorción de lactosa y disminuyen los niveles de colesterol plasmático (Skeaff y col., 2004). Entre los ácidos grasos de cadena corta y media, se encuentran el ácido caproico (C6:0), caprílico (C8:0), cáprico (C10:0) y láurico (C12:0) 
que son los que tienen mayor importancia metabólica (Man y col., 2009).

Las estructuras de las micelas de proteína de las leches de cabra y de oveja difieren de la leche de vaca en el diámetro medio de hidratación, y en la mineralización. Los niveles promedio de mineralización de las micelas en la leche de cabra y de oveja son mayores que en la leche de vaca. Además, contienen más calcio y fósforo inorgánico, están menos solvatadas y son menos estables al calor (Park y col., 2007; Balthazar, 2017).

En síntesis, debido a sus excelentes características tecnológicas citadas, la leche de oveja ha sido utilizada desde hace mucho tiempo principalmente en Europa y medio oriente, en la fabricación quesos típicos regionales hoy considerados como productos gourmet. Además, desde que comenzaron los estudios nutricionales y fisicoquímicos en los alimentos, también se considera que la leche de oveja tiene muchos aspectos positivos como los que se han mencionado.

Otro aspecto beneficioso para la salud a tener en cuenta en el desarrollo de un queso funcional es el contenido de sal que pueden poseer, como consecuencia del proceso de elaboración utilizado. Considerando el aumento del consumo de queso en el mundo, es importante reducir la presencia de sal en el mismo, sin afectar el crecimiento del mercado. Hay que tener en cuenta que, el consumo de una porción de $40 \mathrm{~g}$ de queso (en especial de quesos duros o semiduros) puede proporcionar el 10\% del total de la ingesta diaria recomendada de sal. Se conoce que los altos niveles de sal $(\mathrm{NaCl})$ en la dieta, causan efectos negativos en la salud como el aumento de la presión sanguínea y la disminución de la absorción de calcio (Cruz y col., 2011). La Organización Mundial de la Salud (OMS) señala que el aumento de la presión arterial en el mundo es el principal factor de riesgo de muerte y el segundo de discapacidad por enfermedad cardíaca, accidente cerebro vascular e insuficiencia renal. Especialistas en hipertensión arterial, consideran que toda medida que se adopte respecto a la reducción de sal en las comidas, ayudara a disminuir significativamente en las próximas dos décadas, la incidencia de episodios cardiovasculares como la muerte por infartos de miocardio o ataques cerebro-vasculares (Ley № 26.095 Consumo de Sodio, Senado y cámara de Diputados de la Nación, 2013). Es por esto que, reducir la cantidad de cloruro de sodio en el queso representa un gran desafío para la industria, ya que la sal ejerce funciones específicas, tales como dar sabor, textura y aumentar la vida útil (Floury y col., 2009; Cruz y col., 2011). 
La elección del tipo de producto para desarrollar un alimento funcional implica que debe tener también una buena aceptación por parte del consumidor, por lo que es aconsejable que posea propiedades fisicoquímicas y sensoriales similares a las de los productos del mismo tipo ya existentes en el mercado (Spence, 2006). Por lo tanto, una vez desarrollado el alimento, es necesario evaluar las características físicoquímicas como composición química, microestructura, textura, etc. y los atributos sensoriales como sabor, consistencia, color, apariencia, etc.

\subsection{Evaluación de la calidad del producto desarrollado}

\subsubsection{Evaluación de la microestructura del producto}

Muchas de las propiedades de los quesos, tales como la textura y el sabor, son determinados por la disposición espacial de los componentes presentes: las micelas de caseína que forman una matriz de proteína, los glóbulos de grasa, agua y minerales. La disposición de estos componentes en la escala de micras se conoce como la microestructura del queso. Las condiciones del proceso tecnológico aplicado durante la manufactura y la elección de los ingredientes para su elaboración pueden alterar la microestructura del queso considerablemente, y por lo tanto, las propiedades funcionales del producto final (Lopez, 2005). La posibilidad de visualizar y caracterizar estos cambios es una herramienta importante para el control de calidad de quesos y otros productos lácteos (Ong y col., 2011). Entre las operaciones de proceso que más pueden afectar la microestructura del queso están los tratamientos térmicos y la homogeneización. Esta última puede ser aplicada en la leche o en sus derivados y es de especial interés para la industria láctea porque se utiliza para para reducir el tamaño de los glóbulos de grasa en la leche y cremas y para prevenir la coalescencia y el cremado durante largos períodos de almacenamiento, mejorando por lo tanto su vida útil (Lopez, 2005).

\subsubsection{Evaluación de la textura}

La textura de los alimentos es una experiencia humana muy subjetiva que abarca las propiedades de los alimentos que excitan los sentidos de la vista, el tacto y el oído. La 
Organización Internacional de Normalización (ISO 1992) define la textura de un producto alimenticio como "todos los atributos reológicos y estructurales (geométricos y de superficie) del producto, perceptible por medio de los sentidos del tacto, de la visión y de la audición" (Gunasekaran y Ak, 2003).

La capacidad de medir la textura con precisión y rapidez permite a la industria de alimentos, establecer estándares de calidad y monitorear el deterioro que se puede producir durante el almacenamiento y la distribución de los productos. Para su evaluación, se han desarrollado métodos que cuantifican las propiedades mecánicas del producto alimenticio. El estudio del comportamiento mecánico, es decir, el estudio de la deformación y el flujo de los alimentos como consecuencia de fuerzas aplicadas sobre ellos, cae dentro del campo de la reología de alimentos, que abarca tanto a los alimentos sólidos, semisólidos y líquidos. Las variables básicas utilizadas en el estudio de las propiedades mecánicas de los alimentos son: fuerza, esfuerzo o tensión, deformación y tiempo (Fig. 1.3).

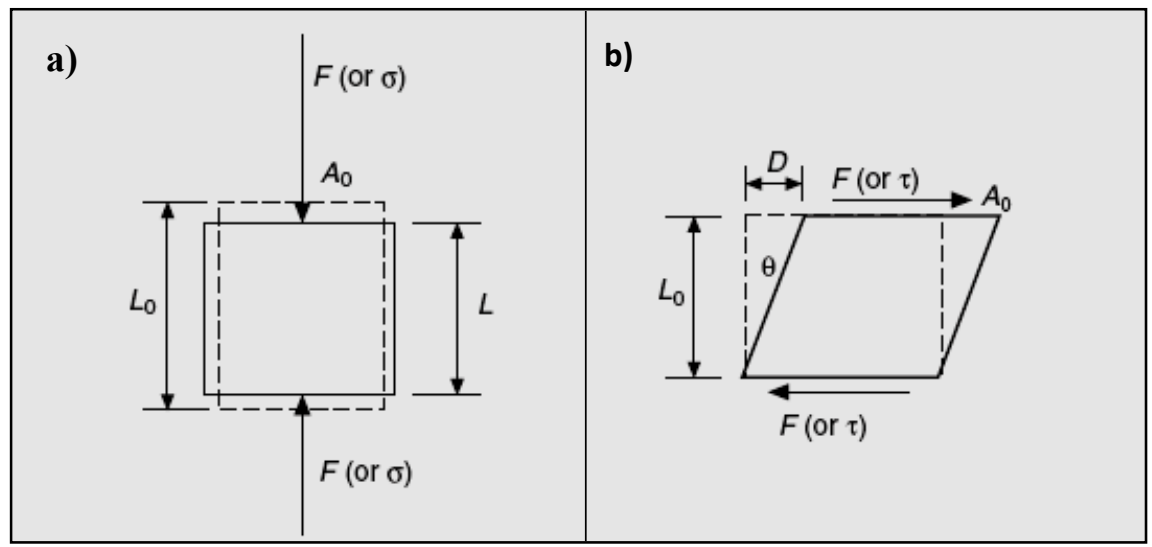

Figura 1.4 (a) Compresión uniaxial o normal de un alimento con una longitud original $\left(\mathrm{L}_{0}\right)$ y área $\left(\mathrm{A}_{0}\right)$ que causa una deformación normal $\varepsilon$ y (b) corte o cizalla de un alimento que actúa sobre planos opuestos que provocan la deformación de corte o cizallamiento $\gamma$.

La fuerza $(\mathrm{F})$ es considerada como una fuerza externa ya que actúa en la superficie (o en un punto de la superficie) del alimento y puede ser normal o tangencial al plano del alimento (Fig. 1.4). La tensión o esfuerzo (simbolizada por $\sigma$ si es normal al plano ó por $\tau$ si es tangencial al plano del objeto) es la reacción del alimento a la fuerza externa aplicada. En correspondencia con los dos tipos de esfuerzo están la deformación normal ( $\varepsilon$ ) y la deformación de cizallamiento $(\gamma)$. Ellas miden el cambio de tamaño o de la forma de un alimento con respecto a su tamaño o forma original y son cantidades adimensionales. Los 
esfuerzos normales son los principales responsables de la expansión o contracción (Fig. 1.4a), es decir, del cambio de tamaño del alimento y los esfuerzos de cizallamiento provocan distorsiones o cambio de ángulo entre dos planos del alimento (Fig. 1.4b).

La relación fuerza/deformación de respuesta a la fuerza externa aplicada, para la mayoría de los productos alimenticios es dependiente del tiempo y/o velocidad de carga por lo tanto, hay ensayos llamados de estado estacionario donde la respuesta medida es constante durante el tiempo del ensayo y hay ensayos en estado transiente en donde la respuesta medida, varía con el tiempo. Además, se han ideado ensayos estáticos y dinámicos (Fig. 1.5). En los primeros, la magnitud de la fuerza aplicada es constante durante el tiempo en el cual se realiza el análisis (Fig. 1.5a). En los segundos, la magnitud de la fuerza aplicada varía en el tiempo en el cual se realiza el análisis. Esta variación puede ser lineal en los llamados ensayos de rampa (Fig. 1.5b) o en ciclos sinusoidales periódicos llamados ensayos oscilatorios dinámicos (Fig. 1.5c). En los ensayos de rampa la magnitud de la fuerza va tomando diferentes valores a diferentes intervalos de tiempo (pasos). Este tipo de ensayo se encuentra entre las categorías de estáticos y dinámicos ya que, cuando hay largos períodos de tiempo entre un paso y el otro se considera como un número consecutivo de ensayos estáticos y cuando los tiempos de espera son cortos (aproximándose a cero) tenemos un ensayo dinámico (Figura y Teixeira, 2007).
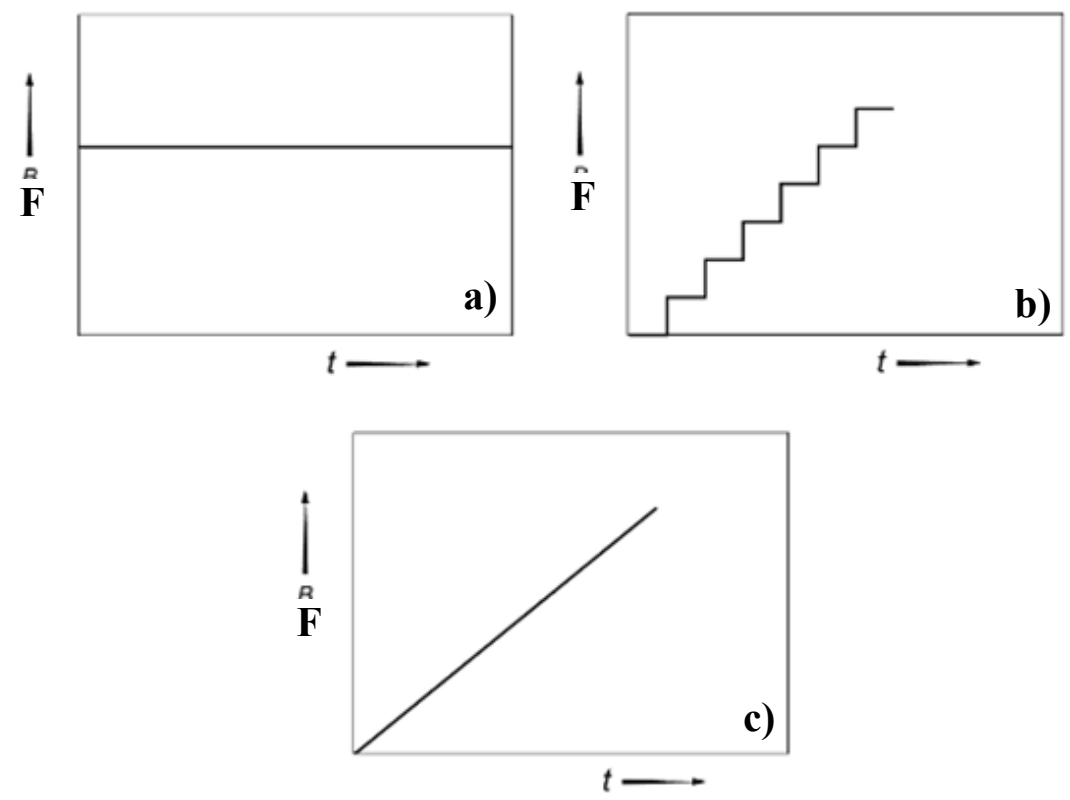

Figura 1.5 Tipos de ensayos y fuerzas aplicados a una muestra: a) estático, b) de rampa y c) dinámico 
Los alimentos son materiales biológicos, y ellos, ya sea en crudo o elaborados, cambian constantemente con el tiempo debido a reacciones químicas (como la oxidación), a la acción microbiana y a las interacciones físicas con el medio ambiente (como el calor y la humedad). En consecuencia, las propiedades mecánicas de los alimentos también cambian con el tiempo y además, pueden ser influenciadas por las condiciones ambientales tales como la temperatura, la humedad, la composición y la presión del aire, y el suministro y consumo de energía. Por consiguiente, una descripción precisa y completa del comportamiento mecánico de los productos alimenticios es una tarea extremadamente difícil y, afortunadamente, para muchas aplicaciones, no es necesaria (Lu y Abbott, 2004). En resumen, como consecuencia de la diversidad de los productos, la variedad de atributos necesarios para describir completamente la textura, y los cambios en éstos debido al deterioro de los mismos, la evaluación de la textura es compleja. Por lo tanto, existen diferentes técnicas que pueden ser subjetivas o instrumentales.

La evaluación subjetiva o sensorial permite una mejor detección y descripción de la textura porque implica la utilización de un grupo de personas para cuantificar los atributos de textura de un producto. Sin embargo, se prefieren las mediciones instrumentales sobre las evaluaciones sensoriales, tanto para aplicaciones comerciales y de investigación, porque los instrumentos son más fáciles de utilizar, están ampliamente disponibles, tienden a proporcionar valores consistentes cuando se usan por personas diferentes (a menudo sin entrenamiento), y son menos costosos que los paneles sensoriales (Lu y Abbott, 2004).

Los métodos instrumentales pueden agruparse en: fundamentales, empíricos y/o imitativos. Los métodos fundamentales evalúan propiedades mecánicas bien definidas de los alimentos que, si se miden correctamente, son independientes del método de medición. Para su interpretación se estudian las propiedades reológicas de los materiales desde el punto de vista de la ingeniería. Estas medidas requieren un cuidadoso diseño experimental, configuración del equipo y tener en cuenta el tipo de muestra a evaluar, sin embargo, son muy valiosas en la investigación de las propiedades físicas de los alimentos. Dentro de estos métodos se incluyen la compresión, los test dinámicos y los test transientes (Tunick, 2000). Se han obtenido algunas correlaciones útiles entre la textura sensorial y los datos de la reología dinámica. Wium y Qvist (1997) fueron capaces de distinguir texturas de 
diferentes quesos basados en el módulo complejo $\left(\mathrm{G}^{*}\right)$ y el ángulo de fase $(\delta)$ medidos en pruebas de barrido de frecuencia. Tunick et al. (1990) examinaron las diferencias de textura entre diferentes quesos basados en los parámetros reológicos dinámicos, módulos de almacenamiento $\left(G^{\prime}\right)$, módulo de pérdida $\left(G^{\prime \prime}\right)$ y viscosidad compleja $(\eta$ *); tal distinción no era posible con otros métodos analíticos. A su vez, Drake y col. (1999) observaron buenas correlaciones entre dureza y G' y entre elasticidad y G" (Gunasekaran y Ak, 2003).

Los métodos empíricos cuantifican propiedades mecánicas del alimento como esfuerzo y deformación pero dependen de las condiciones de ensayo. Típicamente consisten en aplicar una fuerza al producto y medir el esfuerzo y la deformación acompañante. Estos métodos tienen parámetros fijos de ensayo tales como: volumen y forma de la muestra, velocidad del ensayo, etc. Muchos de los diferentes dispositivos que existen para aplicar la fuerza sobre las muestras, se han desarrollado dentro de las distintas industrias elaboradoras y son apropiados para sus productos específicos. Incluso para el mismo tipo de producto, diferentes fabricantes de alimentos han desarrollado sus propias sondas de ensayo. Estos métodos empíricos tienen las siguientes ventajas: son simples de realizar, rápidos, se utilizan en la rutina del control de calidad de procesos de elaboración y se pueden medir grandes cantidades de muestras. Sin embargo, la precisión y la reproducibilidad son generalmente pobres, y solo algunos de los parámetros medidos en determinados ensayos pueden correlacionar bien con la textura percibida por los consumidores. De todos modos, se sigue haciendo un amplio uso de ellos en la industria, principalmente para fines de control de calidad.

Los métodos imitativos pretenden reproducir mecánicamente el acto fisiológico de la masticación, y por lo tanto miden varios atributos de la textura de los alimentos. El análisis de perfil de textura (TPA) pertenece a este grupo y se realiza con un texturómetro que comprime la muestra de alimento con una fuerza constante en dos ciclos sucesivos por medio de un embolo plano. Esto imita la acción de molienda de la mandíbula. Los texturómetros difieren en su construcción mecánica y en su capacidad de análisis y adquisición de datos, pero tienen una serie de características importantes en común. Todos tienen un cabezal transversal al cual va unido la sonda o celda de carga, que es impulsada verticalmente a una gama de velocidades constantes, y que puede completar uno o más ciclos con un rango de distancias y/o carga que se pueden fijar. Se pueden utilizar 
diferentes tipos de celdas para comprimir, penetrar, cortar o triturar los alimentos. La fuerza se registra en relación con el tiempo o la distancia de penetración/deformación. El control del equipo, el registro, el almacenamiento y el análisis de los datos se realiza por una computadora. Una ventaja importante de este tipo de instrumentos es que la flexibilidad de diseño permite que sean utilizados para una amplia gama de alimentos. Esto es particularmente útil para las empresas que manejan o fabrican de una gama de productos variados. Las sondas y los porta-muestras se pueden cambiar fácilmente para dar cabida a mediciones en diferentes tipos de productos, dando una precisión adecuada tanto para alimentos relativamente blandos como para alimentos muy duros. Una ventaja adicional es que tales instrumentos se pueden adaptar para llevar a cabo medidas fundamentales de textura (Kilcast, 2004).

Otra manera de clasificar los métodos utilizados en la evaluación de la textura es aquella que discrimina entre ensayos destructivos y no-destructivos. Los métodos de fuerza/deformación destructivos son considerados por muchos como el medio preferido para medir la textura de alimentos ya que suelen estar mejor relacionados con la evaluación sensorial que los métodos no destructivos (Bourne, 2002). Las técnicas destructivas son útiles para proporcionar información sobre la calidad media de un lote de alimentos. Sin embargo, tienen la desventaja que las muestras utilizadas se destruyen en el proceso de medición. Los métodos destructivos pueden ser empíricos o fundamentales. Los métodos destructivos empíricos también son a menudo algo imitativos ya que, semejan la masticación o la preparación del alimento, tales como el untado de la manteca en el pan, el corte de la carne, o el corte de espárragos. Utilizan una gran variedad de sondas que aplican al alimento una fuerza que va más allá del punto de fractura. Basado en el patrón de carga, los métodos destructivos incluyen punción, penetración, compresión, corte o cizalla, torsión, tensión, flexión, equipos para medir el flujo del alimento, etc. (Kilcast, 2004; Lu y Abbott, 2004). Los métodos destructivos fundamentales miden propiedades mecánicas básicas como el módulo de Young, el coeficiente de Poisson, y de módulo de cizallamiento y otros. Cuando el efecto del tiempo es importante, se realizan los ensayos de fluencia y de relajación (Lu y Abbott, 2004).

Los métodos no destructivos permiten que las muestras de alimentos no sean destruidas o degradadas durante el proceso de medición. Como resultado de este requisito 
básico, los niveles de fuerza y/o la deformación deben ser tales que no se rebase el límite que podría causar daños permanentes en el producto alimenticio. Por lo tanto, entran dentro de los métodos fundamentales donde las teorías de la elasticidad y viscoelasticidad de los materiales funcionan bien para describir la respuesta mecánica de los alimentos en condiciones de ensayo donde la fuerza aplicada sea no destructiva. Este tipo de técnicas es muy útil para los alimentos frescos, crudos o sin procesar, que tienen variaciones en la textura inherentes a la de los objetos individuales, como por ejemplo una cosecha frutihortícola. En ellos, las mediciones de textura "promedio" no son suficientes para garantizar la calidad y consistencia de los elementos individuales que componen la producción. Pertenecen a este grupo, por ejemplo, los ensayos oscilatorios dinámicos para alimentos viscoelásticos, en los cuales se aplica una fuerza sinusoidal al producto en un rango de frecuencias y se registra el desplazamiento correspondiente, la aceleración o la velocidad (Lu y Abbott, 2004).

\subsubsection{Evaluación sensorial}

La evaluación sensorial, es un paso lógico y necesario antes de lanzar un producto al mercado. La percepción oral del alimento es compleja e involucra propiedades gustativas, olfatorias, visuales, táctiles y quinestésicas (propiedades mecánicas: dureza, adhesividad), que son evaluadas en conjunto (Meilgaard y col., 1999). Esta percepción, asimismo, está dada por la composición y la estructura del producto.

Los ensayos sensoriales pueden ser divididos en dos categorías: afectivos y analíticos. Los primeros se llevan a cabo con consumidores, importan sus percepciones y preferencias y son muy utilizados para explorar la aceptabilidad que el producto puede tener en el mercado (Foegeding y col, 2003). Los ensayos analíticos se realizan con personas entrenadas y sus respuestas son tratadas como datos instrumentales.

Dentro de los ensayos afectivos o de aceptabilidad se encuentran entre otros, los siguientes métodos: comparación de a pares, ordenamiento de preferencia, escala hedónica. En el primero se busca comparar un producto con otro, ya sea para el mejoramiento de un producto o buscando paridad con la competencia. Este método fuerza una elección de un producto sobre el otro sin indicar si fueron aceptables o no. En el ordenamiento de 
preferencia el objetivo es comparar la preferencia de más de dos muestras. También se utiliza cuando se quiere ordenar una serie de muestras según un mismo atributo. El método de escala hedónica permite saber cuál es el grado de aceptabilidad sensorial de un producto. La persona le asigna un puntaje dentro de la escala que se le presenta a un atributo en especial del alimento o a la preferencia global del mismo (Cruz y col., 2010).

\subsection{Métodos de conservación de los quesos frescos}

Los quesos frescos de consistencia untable son producidos sin una etapa de maduración, se almacenan comúnmente refrigerados en sus envases y tienen una vida útil limitada (Heller y col., 2003). Algunas características fisicoquímicas como la textura y la liberación de suero de los quesos, pueden variar durante el almacenamiento refrigerado o congelado, disminuyendo su calidad (Lawrence y col., 1987). El agregado de fibra dietaria puede ayudar en la conservación del queso, ya que es un excelente agente texturizante y minimiza la sinéresis (Iop y col., 1999). Por lo tanto, sería interesante evaluar la técnica de congelación, ya que por ejemplo, se suele utilizar éste método para prolongar la vida útil de queso que luego va a ser utilizado como ingrediente en la preparación de otro producto por ejemplo en los quesos untables tratados térmicamente (Zehren y Nausbaun, 2000).

La congelación es un medio excelente para mantener casi inalteradas, durante un tiempo prolongado, las características originales de alimentos perecederos, es decir elevar su vida útil. Éste tipo de conservación radica en la disminución de la temperatura, generalmente entre $-18^{\circ} \mathrm{C}$ a $-30^{\circ} \mathrm{C}$, lo cual permite que las reacciones bioquímicas sean más lentas e inhibe la actividad microbiana, generando el estado de latencia en los microorganismos. Durante este proceso el agua contenida es transformada en hielo disminuyendo así la actividad acuosa del sustrato (Fennema y col., 1973).

El proceso de congelación incluye congelación, almacenamiento congelado y la descongelación. La etapa de congelación puede a su vez subdividirse en: subenfriamiento, nucleación y crecimiento de los cristales formados. Durante la congelación se puede producir daños mecánicos provocados por el incremento del volumen del agua al congelarse, daños por deshidratación celular debido al flujo osmótico del agua desde el interior hacia el espacio extracelular, y daños causados por la migración de solutos desde las zonas en las que primero se inicia la cristalización hacia las que se congelan en último 
lugar (Madrid y col., 1994; Barreiro Mendez y col., 2006). Todo esto puede provocar modificaciones indeseables de $\mathrm{pH}$, acidez, viscosidad, tensión superficial y potencial redox. La congelación también puede producir efectos variables sobre las enzimas presentes en el alimento y dependiendo de las características de cada enzima, se pueden inactivar o activar total o parcialmente, por las variaciones del medio en el que se encuentran. También pueden existir alteraciones debidas a fenómenos químicos, como cambios en el aroma y el color por reacciones químicas asociadas o no a procesos enzimáticos (Fennema y col., 1973).

La pérdida de calidad de los productos congelados se puede evitar realizando una congelación rápida para generar numerosos cristales intra y extracelulares de pequeño tamaño que no dañen los tejidos, manteniendo la cadena de frío durante el almacenamiento, y tratando de que la temperatura de congelación sea la menor posible para minimizar la velocidad de cambios químicos y biológicos indeseados. Además, hay que tener en cuenta que durante la descongelación se debe evitar el sobrecalentamiento y deshidratación para obtener un producto descongelado de igual calidad que el inicial (Gruda y Postolski, 1986). También hay que evitar congelaciones y descongelaciones sucesivas que alteran en gran medida las características fisicoquímicas del producto ya que exponer los productos lácteos que tienen una etapa de gelificación en su elaboración, a varios ciclos de congelado y descongelado puede romper el gel (Corley y Doan, 1940; Doan y Featherman, 1937).

Los alimentos fluidos como la leche y productos lácteos semisólidos como la crema, los quesos blandos con y sin maduración y la ricota, pueden retener su sabor y color original por extensos periodos de tiempo, almacenados a temperaturas cercanas a $-18^{\circ} \mathrm{C}$ (Herrmann, 1977). Sin embargo, también pueden producirse alteraciones físicoquímicas durante la congelación y el almacenamiento congelado. Por ejemplo, pueden aparecer cantidades apreciables de agregados de materia grasa en crema descongelada debido a que la emulsión puede desestabilizarse durante el proceso de congelación (Fennema y col., 1973). También puede aparecer un ligero sabor rancio debido al deterioro oxidativo en los quesos de alta humedad con gran contenido de materia grasa, pero su aparición puede depender de los materiales empleados para su almacenamiento congelado (Webb, 1977). Por otra parte, tiene escaso interés la congelación de quesos duros y de quesos en lonchas debido a que su textura se torna pajiza, migajosa y seca por la extracción de agua que 
sufren durante la congelación y almacenamiento congelado (Herrmann, 1977; Madrid y col., 1994).

\subsection{Objetivos del trabajo de tesis}

Teniendo en cuenta que los quesos de pasta blanda y muy blanda son los más consumidos en América Latina y en especial en Argentina como se ha mencionado, son una buena elección para introducir aditivos beneficiosos para la salud como la fibra dietaria con el objetivo de aumentar el consumo de ésta última y alcanzar los niveles recomendados para la salud. Sin embargo, se ha observado la modificación de algunas características como la textura y el sabor debido a la adición de fibra dietaria en productos lácteos (Dello Staffolo y col., 2004 y 2007; Montesinos-Herrero y col., 2005). Por consiguiente, es necesario el estudio de las propiedades fisicoquímicas y la aceptabilidad de los productos novedosos. Como materia prima principal, la leche de oveja es un excelente producto para elaborar quesos debido a sus características tecnológicas y saludables. Siguiendo la línea de los productos saludables sería interesante disminuir y/o eliminar el contenido de sal en los quesos sin disminuir su aceptabilidad por parte de los consumidores. Además, para conservar mejor y por más tiempo el producto, es de interés introducir una etapa de homogeneización en la elaboración de los quesos y abordar el estudio de la congelación como técnica de preservación y su influencia en los parámetros de calidad.

\subsubsection{Objetivo general}

El objetivo general del presente trabajo es desarrollar quesos frescos untables, con y sin sal agregada, de leche ovina con la adición de fibra dietaria de distintas fuentes, evaluando también, una etapa de homogeneización a fin de lograr productos que, además de ser aceptados por los consumidores, sean nutritivos, beneficiosos para la salud y tengan un tiempo de vida útil superior a los quesos del mismo tipo que se comercializan hoy en día. Para ello, se caracterizaron sus propiedades físicoquímicas y sensoriales y se estudió el efecto del almacenamiento congelado en los parámetros de calidad. 


\subsubsection{Objetivos específicos}

- Formulación de quesos frescos untables adicionados con diferentes fibras.

- Evaluación de la incorporación de etapas adicionales en el proceso de elaboración, como la homogeneización y el agregado de sal.

- Evaluación del rendimiento quesero

- Determinación de la composición centesimal y valor calórico de los productos desarrollados.

- Observación de la microestructura de los productos desarrollados mediante microscopía laser confocal.

- Estudio de la textura instrumental mediante métodos fundamentales y empíricos de los quesos con y sin homogeneizar, con y sin sal agregada y con y sin fibra.

- Análisis sensorial de los quesos con y sin homogeneizar, con y sin sal agregada y con y sin fibra.

- Efecto del almacenamiento congelado en las propiedades fisicoquímicas y sensoriales de los quesos formulados.

- Estudio del efecto del almacenamiento congelado en la oxidación lipídica de la materia grasa de los quesos envasados con películas de diferente permeabilidad al oxígeno. 


\section{CAPÍTULO 2}

\section{MATERIALES Y MÉTODOS}




\subsection{Materias primas empleadas y sus características}

\subsubsection{Leche ovina}

La leche empleada fue obtenida de ovejas de raza Pampinta del tambo de la Estación Experimental Anguil del Instituto Nacional de Tecnología Agropecuaria (INTA) ubicado a $5 \mathrm{Km}$ de la ciudad de Santa Rosa, La Pampa, según buenas prácticas ganaderas. La leche se envasó en bidones plásticos de 20 litros de capacidad, cerrados con tapa a rosca, se congeló y se envió al CIDCA en trasporte especializado que mantuvo la cadena de frío durante el viaje. En el instituto se almacenó en una cámara de refrigeración a una temperatura de $-20 \pm 1{ }^{\circ} \mathrm{C}$ hasta su uso en la elaboración de los quesos. Dos días antes de la preparación de los quesos se descongeló la leche contenida en un bidón, en forma lenta en una cámara de refrigeración a $4{ }^{\circ} \mathrm{C}$, para evitar la alteración de sus características fisicoquímicas.

\subsubsection{Microorganismos empleados en la manufactura del queso}

Los microorganismos utilizados son Lactococcus lactis subsp. lactis $\mathrm{y}$ Lactococcus lactis subsp. cremoris que forman parte de un fermento comercial llamado cultivo mesofílico homofermentativo tipo O, R-704. Este cultivo contiene cepas seleccionadas especialmente por su resistencia a los fagos y su capacidad para producir ácido láctico rápidamente. Además, este cultivo no produce dióxido de carbono. Según el proveedor (Christian Hansen, Inc.), este cultivo de bacterias ácido lácticas debe ser aplicado en la producción de quesos con textura cerrada, por ejemplo Cheddar, Feta y queso cottage (que corresponde con el tipo de queso preparado en este trabajo de tesis). Este cultivo puede aplicarse también, en otros productos lácteos fermentados, en combinación o no con otros cultivos lácticos.

\subsubsection{Fibra dietaria de distintos orígenes}

Se utilizaron fibras de bambú (Qualicel 40B, CFF, Alemania), de trigo (Vitacel WF 101, JRS, Alemania), de raíz de achicoria (inulina Frutafit, Sensus, Bélgica) y cáscara triturada de semillas de Plantago ovata (psyllium, Metamucil, Procter \& Gamble Co., USA) para adicionar a las diferentes formulaciones 
de queso fresco de leche ovina. Las características tecnológicas de las fibras utilizadas se muestran en la Tabla 2.1, proporcionada por los proveedores.

Tabla 2.1 Especificaciones y capacidad de retención de agua [ $\mathrm{g} \mathrm{H}_{2} \mathrm{O} / \mathrm{g}$ de materia seca] para las diferentes fibras, según los proveedores (Dello Staffolo y col., 2017)

\begin{tabular}{|c|c|c|c|c|}
\hline Tipo de Fibra & Bambú & Trigo & Inulina & Psyllium \\
\hline Apariencia & Polvo & Polvo & Polvo & Polvo \\
\hline Color & Blanco & Blanco & Blanco & Blanco \\
\hline Olor & Inodora & Inodora & Inodora & Inodora \\
\hline Sabor & Neutro & Neutro & Escas. dulce & Escas. Dulce \\
\hline $\begin{array}{c}\text { pH (en suspensión } \\
\text { acuosa } 10 \% \text { p/v) }\end{array}$ & $4.0-6.0$ & $4.0-6.0$ & Neutro & Neutro \\
\hline Retención de Agua & $3.19^{\mathrm{a}} \pm 0.09$ & $3.61^{\mathrm{b}} \pm 0.01$ & $\mathrm{NE}$ & $42.51^{\mathrm{c}} \pm 0.50$ \\
\hline Metales Pesados & $\mathrm{Pb}<10 \mathrm{ppm}$ & $\mathrm{Pb}<10 \mathrm{ppm}$ & No Contiene & - \\
\hline
\end{tabular}

${ }^{a}$ Diferentes letras indican diferencias significativas entre las muestras (Tukey: $\alpha=0,05$ ). NE: no evaluado

La inulina empleada contiene $\geq 85,5 \% \mathrm{p} / \mathrm{p}$ de inulina, $\leq 9,5 \% \mathrm{p} / \mathrm{p}$ de mono $\mathrm{y}$ disacáridos, $\leq 0,1 \% \mathrm{p} / \mathrm{p}$ de cenizas y tiene un grado de polimerización $\geq 9$. El psyllium usado es una fórmula farmacéutica llamada comercialmente Metamucil, que contiene cáscara triturada de semilla de Plantago ovata $(49,15 \% \mathrm{p} / \mathrm{p})$ y sacarosa $(50,85 \% \mathrm{p} / \mathrm{p})$. Se utilizó fibra de trigo libre de ácido fítico y de gluten. En la Tabla 2.2 se detalla la caracterización fisicoquímica de las distintas fibras.

Tabla 2.2 Contenido de fibra total, fibra soluble, fibra insoluble y los principales componentes de la pared celular (celulosa, hemicelulosa y lignina) de las fibras de bambú, trigo y psyllium

(Dello Staffolo y col., 2011).

\begin{tabular}{lccc}
\hline Fibra & Bambú & Trigo & Psyllium \\
\hline Fibra total & $95.3^{\mathbf{b}} \pm 0.9$ & $94.4^{\mathbf{b}} \pm 1.1$ & $45.2^{\mathbf{a}} \pm 0.8$ \\
Fibra insoluble & $91.4^{\mathbf{b}} \pm 0.5$ & $92.1^{\mathbf{b}} \pm 0.6$ & $37.5^{\mathbf{a}} \pm 0.6$ \\
Fibra soluble & $3.2^{\mathbf{a}} \pm 0.8$ & $2.3^{\mathbf{a}} \pm 0.6$ & $7.1^{\mathbf{b}} \pm 0.5$ \\
Celulosa & $48.7^{\mathbf{b}} \pm 1.0$ & $72.2^{\mathbf{c}} \pm 0.7$ & $6.5^{\mathbf{a}} \pm 0.4$ \\
Hemicelulosa & $40.2^{\mathbf{c}} \pm 1.7$ & $14.9^{\mathbf{a}} \pm 0.9$ & $29.5^{\mathbf{b}} \pm 1.3$ \\
Lignina & $2.0^{\mathbf{b}} \pm 0.1$ & $2.6^{\mathbf{b}} \pm 0.4$ & $0.8^{\mathbf{a}} \pm 0.1$ \\
\hline
\end{tabular}

${ }^{\mathrm{a}}$ Diferentes letras indican diferencias significativas entre las fibras

La inulina no se incluyó en esta Tabla 2.2 debido a que es una fibra soluble que se obtiene por extracción y purificación de la raíz de achicoria. Este proceso elimina la 
celulosa, la hemicelulosa y la lignina.

\subsubsection{Determinación de la distribución del tamaño de partícula de las fibras} empleadas

La distribución del tamaño de partículas de las fibras empleadas que se adquieren a los proveedores como polvos fue obtenida por difracción/dispersión laser con el equipo Horiba LA-950 (Kyoto, Kyoto Prefecture, Japón) formado por un sistema óptico doble (diodo de $650 \mathrm{~nm}$ y diodo emisor de luz de $405 \mathrm{~nm}$ ) y detectores de fotodiodos de silicio (Figura 2.1). Las medidas de los tamaños de partículas fueron realizadas por triplicado para cada fibra.

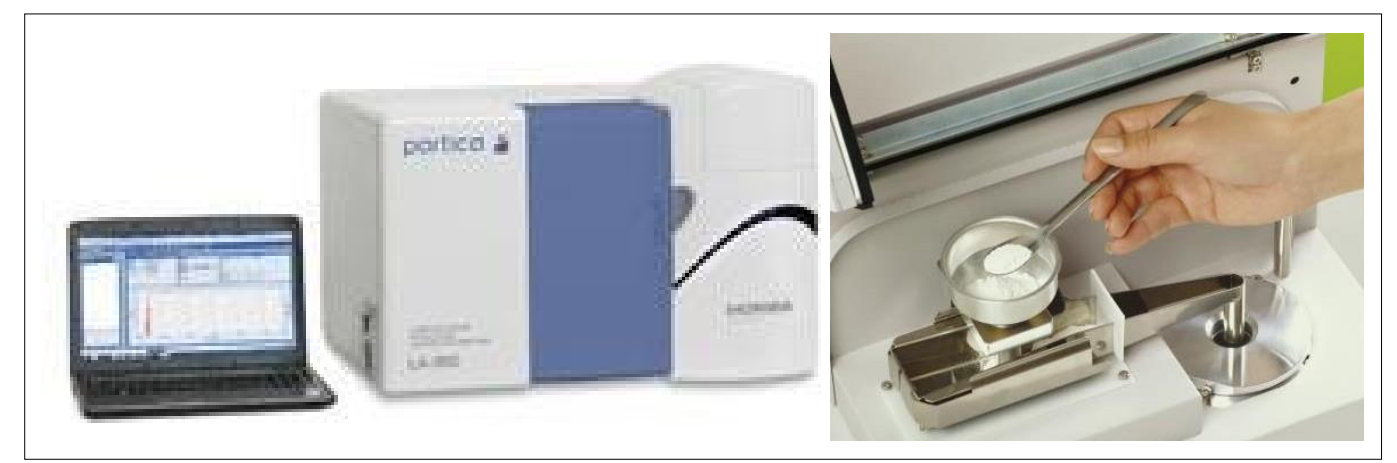

Figura 2.1 Analizador de tamaño de partículas Horiba LA-950. a) vista total del equipo y b) zona de carga de la muestra.

\subsection{Proceso de elaboración de queso fresco untable de leche ovina funcional adicionado con fibra dietaria de distintos orígenes}

\subsubsection{Determinación de la fuerza de cuajado de la leche}

Las sustancias coagulantes que se utilizan en la industria lechera son un punto muy importante a tener en cuenta ya que influyen en la calidad del producto final. Estas sustancias actúan sobre las micelas de caseína, que están en solución coloidal, desnaturalizándolas y generando la precipitación y formación del gel de caseína. Este gel se caracteriza por su consistencia semisólida y gelatinosa y posee cierta estabilidad y elasticidad. La naturaleza de este gel formado afecta las etapas posteriores de la elaboración del queso, como la separación del suero, humedad del producto final, etc. Estas sustancias coagulantes pueden tener tres orígenes: animal, vegetal y microbiano. En este trabajo de tesis se empleó cuajo de origen animal que es una mezcla de las 
enzimas quimosina (en mayor proporción), catepepsina y pepsina (en menores proporciones) proveniente de los folículos pilosos de la cuarta cavidad estomacal de los rumiantes en estado de lactación. Puede presentarse en forma de solución o liofilizada. En este trabajo de tesis se utilizó la presentación líquida de la enzima solubilizada.

Para determinar la fuerza de cuajado de la leche ovina utilizada, se tomó $100 \mathrm{~mL}$ de leche pasteurizada en un vaso de precipitado que se colocó en un baño termostatizado a $35 \pm 1^{\circ} \mathrm{C}$. Cuando la leche alcanzó la temperatura del baño, se colocó $1 \mathrm{~mL}$ de cuajo que se encontraba a temperatura ambiente, se homogeneizó y se registró el tiempo hasta que una varilla de plástico se sostuvo verticalmente debido a la coagulación o gelificación de la muestra. Para sacar la fuerza de cuajo se utilizó la siguiente ecuación:

$$
\mathrm{F}=\frac{2400 \times 100 \mathrm{~mL} \text { de leche }}{1 \mathrm{~mL} \text { de cuajo } \times \mathrm{t} \text { en seg que tardó en coagular }}
$$

Luego, con este parámetro se obtuvo la cantidad de cuajo a agregar a la leche pasteurizada para la elaboración del queso con la siguiente Ecuación 2.2:

$$
\mathrm{mL} \text { de cuajo }=\frac{40000 \times 35^{\circ} \mathrm{C} \times \text { volumen de leche a coagular }}{\text { t que se almacena } a 20^{\circ} \mathrm{C} \times 20^{\circ} \mathrm{C} \times F}
$$

\subsubsection{Manufactura del queso}

Para la realización de un lote de queso fresco untable, se calentó a baño maría un volumen determinado de leche de oveja hasta llegar a $65^{\circ} \mathrm{C}$ y se lo mantuvo durante 30 minutos con el objetivo de pasteurizar la leche. Luego de completado este proceso, se bajó la temperatura de la leche a $29 \pm 1{ }^{\circ} \mathrm{C}$ utilizando un baño de hielo. Se agregó cloruro de calcio $25 \% \mathrm{p} / \mathrm{v}$ a razón de $1 \mathrm{~mL}$ por litro de leche y fermento mesófilo homofermentativo R-704 (Christian Hansen, Inc.) como cultivo iniciador. La cantidad de este fermento se calculó exactamente para cada elaboración de queso según las especificaciones del proveedor. Se dejó $2 \mathrm{~h}$ a $29 \pm 1{ }^{\circ} \mathrm{C}$ para que los microorganismos pudieran comenzar a crecer según el diagrama de flujo que se muestra en el Gráfico 2.1. Luego se bajó la temperatura a $20 \pm 1^{\circ} \mathrm{C}$ y se agregó una cantidad de cuajo líquido de origen animal (Porteau Rural, Bavio, provincia de Buenos Aires, Argentina) calculada 
mediante la determinación de fuerza del cuajo detallada en el ítem anterior. Posteriormente se dejó durante $18 \mathrm{~h}$ en un cuarto a $20 \pm 1^{\circ} \mathrm{C}$, tiempo en el cual se produjo la coagulación la leche.

Luego de este tiempo, se retiró la cuajada del cuarto a $20 \pm 1{ }^{\circ} \mathrm{C}$. Se procedió al lirado en cruz de la cuajada y las porciones obtenidas se dispusieron en bolsas de tela de gasa de algodón. Este tipo de tejido tiene un entramado que permite el pasaje del suero del queso. Se dejaron las bolsas suspendidas reposando durante $4 \mathrm{~h}$ para que drene el suero. La cuajada desuerada contenida en las bolsas se depositó en un recipiente limpio y seco, según las buenas prácticas de manufactura y se pesó para poder obtener el rendimiento como se detalla en el siguiente ítem. Esta cuajada es el queso tipo fresco de consistencia untable utilizado como base para el desarrollo de los quesos funcionales.

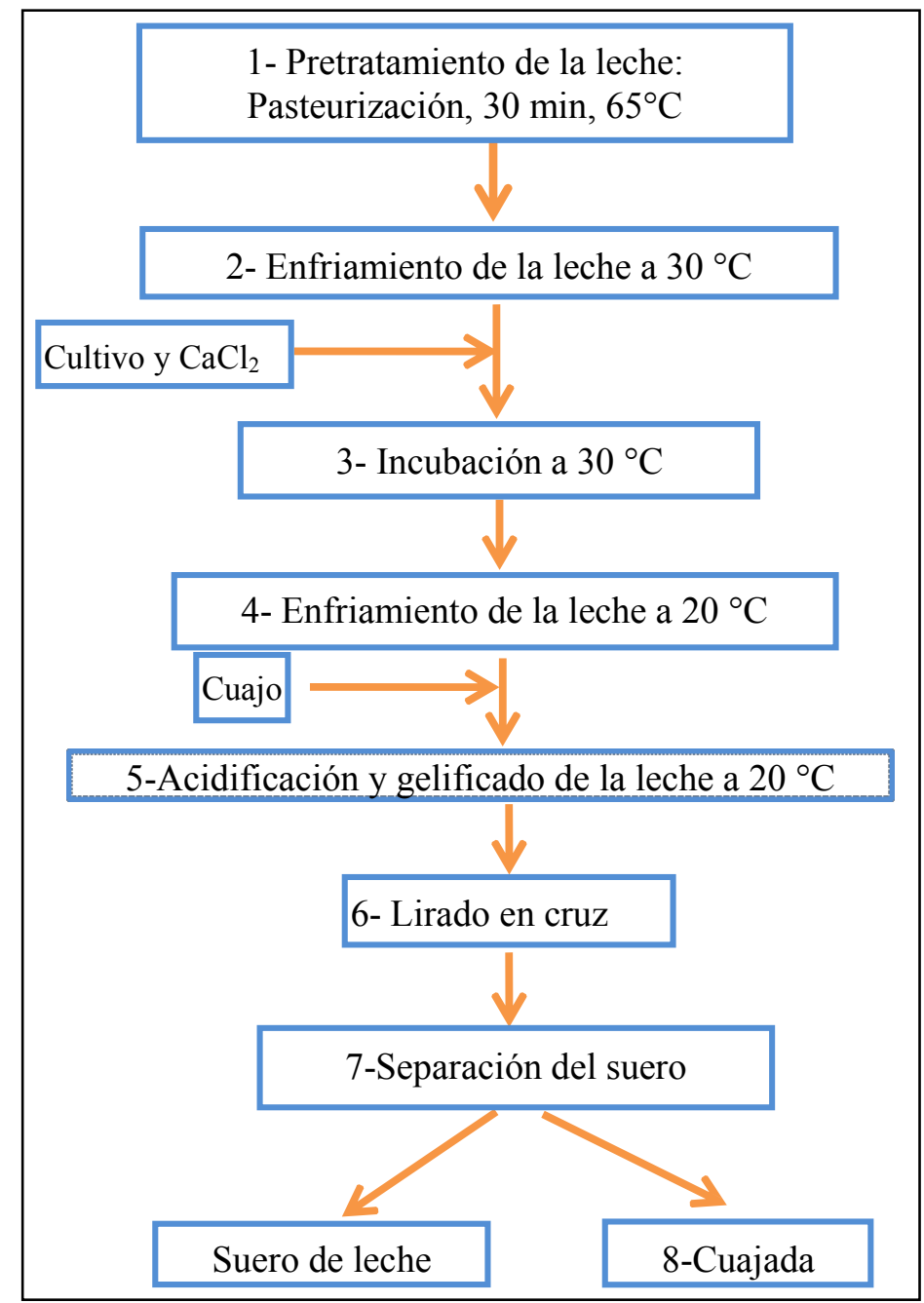

Gráfico 2.1. Esquema de la elaboración del queso fresco untable 


\subsubsection{Rendimiento quesero}

Se denomina rendimiento quesero a la cantidad de queso obtenido a partir de un determinado volumen de leche y se expresa como $\mathrm{kg}$ de queso/L de leche. Se determinaron los rendimientos queseros de todas las elaboraciones realizadas durante el trabajo de tesis, midiendo el volumen de leche utilizado y el peso del queso final producido, se calculó el rendimiento y se obtuvo el promedio de todas las elaboraciones.

\subsubsection{Desarrollo de las formulaciones de quesos funcionales}

Con el fin de obtener alimentos funcionales y de estudiar el efecto de la adición de sal y de fibras de distinto origen, así como también la incorporación de una etapa de homogeneización en la elaboración de queso untable de leche ovina, se ideó el proceso de elaboración que se presenta en el Gráfico 2.2. La cuajada obtenida se dividió en dos partes. A una de ellas se le adicionó $0,3 \% \mathrm{p} / \mathrm{p}$ de sal (cloruro de sodio, $\mathrm{NaCl}$ ), ya que los quesos del mismo tipo manufacturados a partir de leche de vaca, que hoy se venden en Argentina, llevan la incorporación de sal en su proceso industrial (entre 0,2 y 0,4 \% p/p según la marca).

Además, se utilizaron 4 tipos diferentes de fibra dietaria en polvo que se agregaron a los quesos con y sin sal en un $3 \pm 0,1 \% \mathrm{p} / \mathrm{p}$ según lo reglamentado por el Código Alimentario Argentino (C.A.A) en el artículo 1386. De esta manera, se obtuvieron los siguientes quesos untables funcionales: queso con fibra de bambú (QFB), queso con fibra de trigo (QFT), queso con inulina (QFI), queso con Psyllium (QFP) y queso sin fibra (QSF).

La mitad de los quesos con y sin sal, con y sin fibras fueron homogeneizados con procesador (Philips, Argentina) $10 \mathrm{~s}$ a velocidad máxima, 3 veces para lograr que toda la masa del queso quede bien homogeneizada.

Luego se realizó el envasado de los quesos según el ensayo a realizar y su posterior almacenamiento congelado. 
Materiales y Métodos

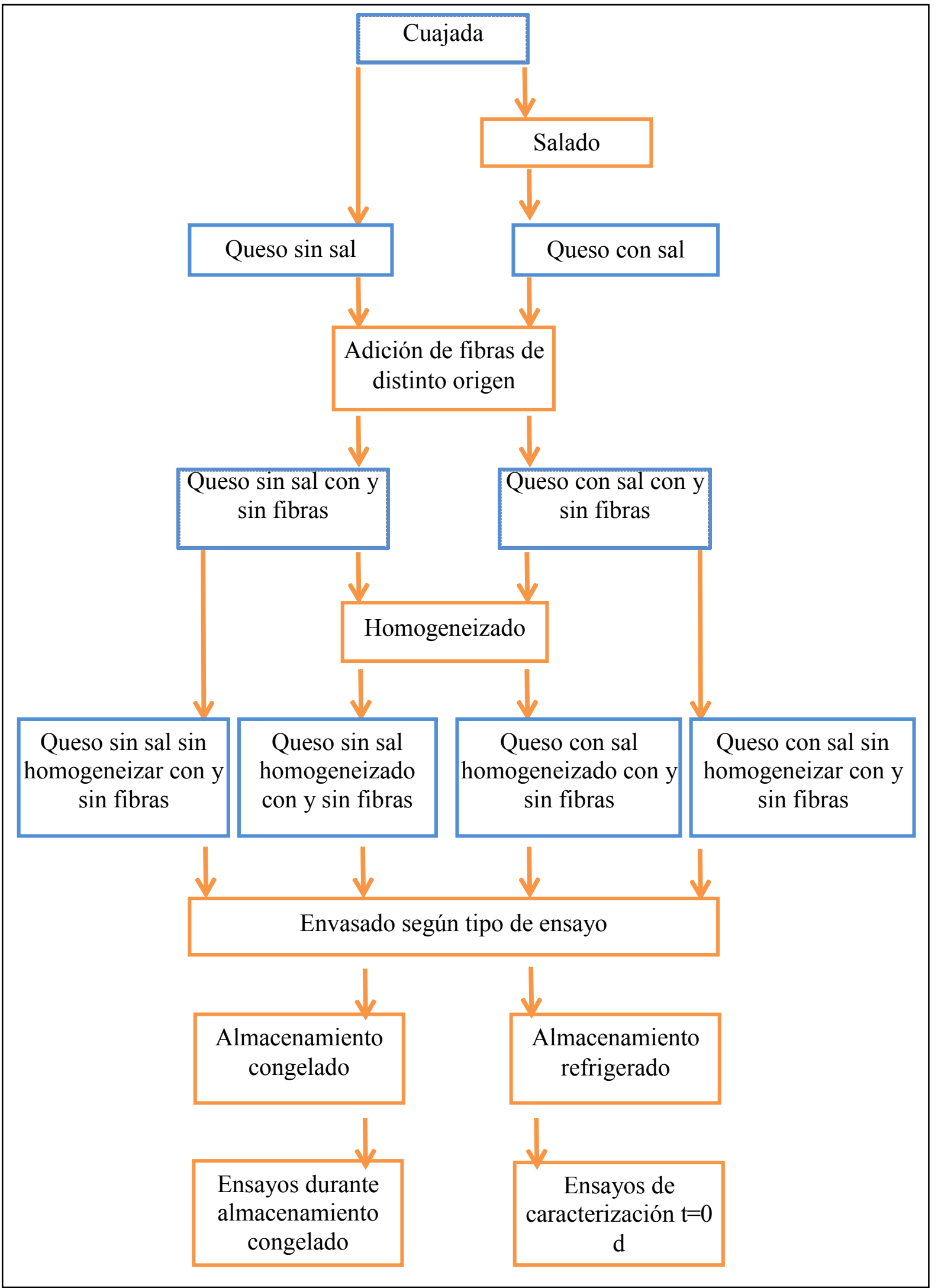

Gráfico 2.2 Elaboración de los quesos funcionales adicionados con fibra dietaria de distintos orígenes 


\subsection{Ensayos efectuados en los quesos funcionales}

En la Tabla 2.3 pueden observarse las pruebas llevadas a cabo con las formulaciones de quesos funcionales recién elaborados luego de $8 \mathrm{~h}$ de almacenamiento refrigerado $\left(8^{\circ} \mathrm{C} \pm 1^{\circ} \mathrm{C}\right)$ y durante el almacenamiento congelado $\left(-20 \pm 1^{\circ} \mathrm{C}\right)$ por tres meses.

Tabla 2.3 Diagrama de los experimentos realizados con los quesos funcionales elaborados

\begin{tabular}{ll}
\multicolumn{1}{c}{ Evaluación del producto } & \multicolumn{1}{c}{ Ensayos durante } \\
\multicolumn{1}{c}{ terminado } & \multicolumn{1}{c}{ almacenamiento congelado } \\
\hline - $\mathrm{pH}$ & - $\mathrm{pH}$ \\
- Composición proximal & - Liberación de suero \\
- Microscopía Laser Confocal & - Microscopía Laser Confocal \\
- Evaluación instrumental de & - Evaluación de textura: ensayo \\
textura: ensayo oscilatorio & de compresión-extrusión \\
dinámico y de compresión- & - Oxidación de lípidos \\
extrusión & - Evaluación sensorial \\
- Evaluación sensorial &
\end{tabular}

\subsubsection{Evaluación del producto terminado}

\subsubsection{Medición de pH}

Se realizaron las mediciones de $\mathrm{pH}$ de los quesos recién elaborados. Se utilizó un peachimetro Hach, modelo EC-30 (USA) con un electrodo de punta de vidrio, de Broadley James Corporation (USA). Las medidas se realizaron por duplicado.

\subsubsection{Composición centesimal}

\subsection{Determinación de humedad}

Se determinó por desecación usando el método oficial (AOAC 1984, 24.002). En cristalizadores tarados con varilla de vidrio y arena previamente lavada (con $\mathrm{HCl}$ diluido) y calcinada, se pesó 5,0 $\pm 0,5 \mathrm{~g}$ de cada tipo de queso elaborado. Se disgregaron 
las muestras con la arena para facilitar el secado. Se llevaron a estufa a $100-103{ }^{\circ} \mathrm{C}$ hasta peso constante, obteniéndose los residuos secos. Los resultados se expresaron como g de agua/100 g de queso utilizando la Ecuación 2.3. Todas las determinaciones se realizaron por duplicado de dos lotes de queso.

$$
\begin{aligned}
& \text { Humedad }[\%]=\frac{\left(\text { Peso }_{\mathrm{mH}}-\text { Peso }_{\mathrm{mS}}\right) \times 100}{\text { Peso }_{\mathrm{mH}}} \\
& \text { Peso }_{\mathrm{mH}}=\text { Peso de la muestra humedad } \\
& \text { Peso }_{\mathrm{mS}}=\text { Peso de la muestra seco }
\end{aligned}
$$

\subsection{Determinación de cenizas}

La determinación de cenizas se realizó por el método AOAC (1984, 24.009), en cápsulas de porcelana previamente calcinadas y taradas, se pesaron con exactitud 3,0 \pm 0,5 g de muestra de los quesos elaborados. Se carbonizaron sobre mechero y tela metálica hasta residuo carbonoso y posteriormente se calcinaron en mufla a $550^{\circ} \mathrm{C}$ hasta cenizas blancas $(3 \mathrm{~h})$. Las muestras se enfriaron en la mufla hasta $50{ }^{\circ} \mathrm{C}$ y luego en desecador hasta alcanzar la temperatura ambiente. Los resultados se expresaron como g de cenizas cada $100 \mathrm{~g}$ de queso y se calcularon mediante la Ecuación 2.4. Se determinó el porcentaje de cenizas utilizando la siguiente fórmula:

$$
\text { Ceniza }[\%]=\frac{\text { peso final muestra }}{\text { peso inicial muestra }} \times 100
$$

\subsection{Determinación de materia grasa}

Para la cuantificación de la materia grasa se utilizó el método de solubilización de Schmid-Bondzynski-Ratzlaff (IDF 5/ ISO 1735:2004). Se utilizaron dos muestras de cada formulación. Para ello, se pesó alrededor de $10 \mathrm{~g}$ de queso en balanza analítica (Sartorius, USA) de cada muestra, se agregó $10 \mathrm{~mL}$ de ácido clorhídrico concentrado y se mezcló para que se desintegre la estructura del queso. Se trasvasó a una probeta esmerilada y se agregó 50-60 mL de éter lavando el vaso donde estaba el queso para arrastrar toda la muestra con dos porciones de $10 \mathrm{~mL}$ de alcohol etílico. Se agitó 20 veces por inmersión la probeta tapada. Se dejó media hora en reposo y luego se extrajo 
$20 \mathrm{~mL}$ de éter y se colocó en vasos de precipitados previamente rotulados y pesados. Se evaporó el éter toda la noche en oscuridad y sin calor hasta el día siguiente. Se pesó nuevamente para obtener por diferencia la cantidad de lípidos extraídos. Este es un método elegido para determinar los lípidos en quesos, ya que estos pueden contener ácidos grasos libres y con el método de Röse-Gottlieb (específico para leche fresca) estos pueden forman sales de amonio que son insolubles en éter (Boekenoogen, 1964).

\subsection{Determinación de proteínas}

Las proteínas totales se cuantificaron mediante el método de Kjeldahl-ArnoldGunning que determina nitrógeno (AOAC 1984, 24.027) en un equipo digestor y destilador Büchi K-350 (Figura 2.2). Se utilizó el factor 6,38 para productos lácteos, para la conversión del contenido de nitrógeno en proteína. Los resultados se expresaron como $g$ de proteínas cada $100 \mathrm{~g}$ de quesountable.

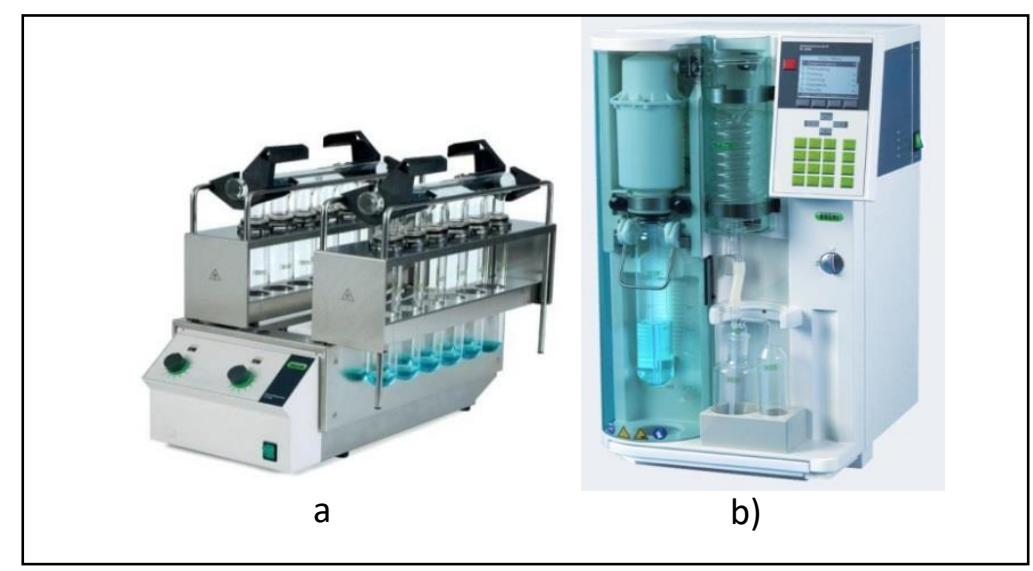

Figura 2.2 a) equipo digestor y b) equipo destilador Büchi para método Kjeldahl

El método consiste en la destrucción de la materia orgánica empleando ácido sulfúrico concentrado. El trióxido de azufre formado durante el tratamiento a altas temperaturas se adiciona al grupo $-\mathrm{NH}$ - de los enlaces peptídicos formando ácido amidosulfónico. Este ácido es resistente a una posterior oxidación y se transforma en sulfato amónico por degradación. El nitrógeno del sulfato de amonio se libera a continuación como amoníaco por alcalinización y destilación. Luego el amoníaco se cuantifica por medio de una valoración ácido-base. El procedimiento consta de cuatro 
etapas: a) digestión, b) neutralización, c) destilación y d) valoración, llevadas a cabo de la siguiente manera:

a) digestión: En esta etapa se produce la degradación oxidativa de los compuestos orgánicos de la muestra con ácido sulfúrico concentrado a temperaturas comprendidas entre 360 y $410^{\circ} \mathrm{C}$. El ácido sulfúrico concentrado actúa como hidrolizante, deshidratante, disociante, oxidante y proporciona el medio ácido para fijar el $\mathrm{NH}_{3}$ en forma de $\mathrm{NH}_{4} \mathrm{HSO}_{4}$. La reacción general puede indicarse como:

$$
\text { Materia Orgánica }+\mathrm{H}_{2} \mathrm{SO}_{4}+\text { Sales } \rightarrow \mathrm{CO}_{2}+\mathrm{H}_{2} \mathrm{O}+\mathrm{NH}_{4} \mathrm{HSO}_{4}
$$

Se realizaron cálculos previos para determinar la cantidad de muestra a pesar, para tener un consumo de $\mathrm{HCl}(0,1 \mathrm{M})$ aproximado de $15 \mathrm{~mL}$ en la valoración final. En dichos cálculos se utilizó un valor estimativo de proteínas en el queso de $12 \%$ observado en los rótulos de los quesos comerciales del mismo tipo.

Se pesaron muestras de los distintos quesos de 1,3 $\pm 0,1 \mathrm{~g}$ y se colocaron en el fondo de los tubos de digestión de vidrio Pyrex envueltas en film de plástico. Se adicionaron $2 \mathrm{~g}$ de mezcla catalizadora $\left(\mathrm{Na}_{2} \mathrm{SO}_{4}, \mathrm{y} \mathrm{K}_{2} \mathrm{SO}_{4}\right.$ anhidros con $\mathrm{CuSO}_{4} .5 \mathrm{H}_{2} \mathrm{O}$ en relación 10:1) y perlas de vidrio que facilitan la remoción y evitan el sobrecalentamiento. El catalizador eleva la temperatura (ascenso ebulloscópico) a más de $350{ }^{\circ} \mathrm{C}$, reduciendo el tiempo de digestión. Finalmente, se agregaron $15 \mathrm{~mL}$ de $\mathrm{H}_{2} \mathrm{SO}_{4}$ concentrado y se conectaron los tubos de digestión a una trampa que permite retirar los vapores de $\mathrm{SO}_{3}$.

La digestión comenzó calentando los tubos suavemente hasta desaparición de la materia carbonosa, incrementando la intensidad de calor a medida que la digestión progresaba. La digestión se dio por finalizada cuando cesó la liberación de humos blancos (vapores de $\mathrm{SO}_{3}$ ) y la solución quedó límpida de un color verde-azulado dado por la formación sulfato cúprico $\left(\mathrm{Cu} \mathrm{SO}_{4}\right)$ con el cobre presente en el catalizador. Se dejó enfriar dentro de la campana conectado a la trampa de vapores.

b) Neutralización: Se adicionó $25 \mathrm{~mL}$ de agua y luego se colocaron los tubos en la unidad de destilación Büchi en donde se realizó la neutralización y la posterior destilación. En este caso se utilizaron en promedio $17 \pm 1 \mathrm{~mL}$ de $\mathrm{NaOH} 32 \%$, para neutralizar $\mathrm{el}_{2} \mathrm{SO}_{4}$ utilizado en la digestión de las muestras (la solución pasa a color pardo por formación de $\mathrm{CuO})$. 
c) Destilación: Luego de la neutralización se puso en marcha el equipo para llevar a cabo la destilación. El destilado se recogió en Erlenmeyer conteniendo $25 \mathrm{~mL}$ de solución ácida $\left(\mathrm{H}_{3} \mathrm{BO}_{3}\right.$ al $4 \%$ p/v) con 3 gotas del indicador de Mortimer (rojo de metilo + verde de bromocresol). Durante esta etapa el indicador viró del naranja (medio ácido) al azul (medio alcalino), destilándose $200 \mathrm{~mL}$, que según la técnica aseguran la recolección del $95 \%$ del nitrógeno.

d) Valoración: Se realizó la valoración con ácido $\mathrm{HCl}$ de normalidad conocida hasta viraje del indicador al color naranja inicial. Previamente se preparó una solución de $\mathrm{HCl}$ de normalidad aproximada $0,1 \mathrm{~N}$. Se calculó la concentración exacta de $\mathrm{HCl}$ con un patrón primario (carbonato sódico anhidro). Se pesó $0,10 \pm 0,01 \mathrm{~g}$ de carbonato de sodio previamente secado en estufa, se disolvió en $25 \mathrm{~mL}$ de agua destilada y se añadieron 5 gotas de naranja de metilo $0,1 \%$ p/v. Se midió el volumen de $\mathrm{HCl} 0,1 \mathrm{~N}$ a valorar que se agregó desde la bureta a la solución de carbonato de sodio para lograr el viraje del indicador del amarillo al rojo-naranja. Esta operación se realizó por triplicado y se tomó como concentración de la solución para el cálculo, el promedio de tres determinaciones.

La cuantificación del contenido de proteínas de los quesos con y sin fibra se realizó por duplicado para cada lote, con un blanco de reactivos que permite considerar la posible presencia de compuestos nitrogenados en los reactivos y en el medio de reacción. El contenido de proteínas se calculó mediante la Ecuación 2.5 y se expresó como g de proteínas en $100 \mathrm{~g}$ de muestra:

$$
[\%]=\frac{\left(V_{m}-V_{b}\right) \times N_{\text {ácido }} \times 0.014 \times F \times 100}{g \text { de muestra }}
$$

$\begin{array}{ll}V_{m} & \text { mL de ácido gastados en la valoración de la muestra } \\ V_{b} & \mathrm{~mL} \text { de ácido gastados en la valoración delblanco } \\ N_{\text {ácido }} & \text { Normalidad del ácido clorhídrico } \\ 0.014 & \text { Peso del meq de nitrógeno, en } \mathrm{g} \\ F & \text { Factor de conversión de nitrógeno a proteína } \\ g_{\text {muestra }} & \text { Peso en g de la muestra }\end{array}$




\subsection{Determinación de hidratos de carbono}

Los hidratos de carbono se determinaron con el método Fehling-Causse-Bonnans modificado (AOAC 1965, p. 495). Este procedimiento se basa en una titulación de punto final, mediante la cual se evidencia el poder reductor de los azúcares, de pasar el $\mathrm{Cu}$ (II) a $\mathrm{Cu}$ (I), el cual se compleja con el ferrocianuro de potasio dando un color amarillo oro en presencia de un indicador. Esto se debe a que cuando un azúcar reductor se calienta en condiciones básicas se degrada y algunos de los productos de degradación reducen los iones cúpricos para formar oxido cuproso (Pomeranz y Meloan, 1984).

Los reactivos utilizados fueron: la solución Fehling-Causse-Bonnans (FCB), solución acuosa de azul de metileno al $1 \% \mathrm{p} / \mathrm{v}$, solución de lactosa $0,5 \% \mathrm{p} / \mathrm{v}$ y solución de glucosa $0,5 \%$. Primeramente, hay que valorar el reactivo FCB. Para ello, en un erlenmeyer de $250 \mathrm{~mL}$ de capacidad se colocan exactamente $10 \mathrm{~mL}$ de reactivo $\mathrm{FCB}, 30$ $\mathrm{mL}$ de agua destilada y 2 o 3 trozos de porcelana porosa y se calienta a ebullición. Una vez alcanzada ésta, se comienza a agregar desde la bureta la solución patrón de azúcar a una velocidad de goteo controlada (medirla) evitando interrumpir la ebullición. Cuando la coloración azul del reactivo disminuye de intensidad o alcanza un tono celeste verdoso, se agregan 3 gotas de la solución acuosa de azul de metileno y se continúa con el agregado de solución patrón, gota a gota, hasta decoloración. La primera gota que torna a amarillo oro parte de la solución indica el punto final. Se debe realizar esta valoración por duplicado. Deben gastarse alrededor de 5-9 $\mathrm{mL}$ de la solución patrón para decolorar $10 \mathrm{ml}$ de reactivo de FCB. Si el volumen gastado cae fuera de estos valores hay que modificar la velocidad de adición hasta lograr el valor indicado. La velocidad de goteo encontrada como óptima será la empleada al valorar las soluciones que provienen de los quesos.

Como los quesos son muestras sólidas se pesó la cantidad de muestra necesaria para obtener aproximadamente una concentración final de $0.5 \%$ de azúcares solubles en la solución a titular. Esto lo podemos saber teniendo en cuenta que previamente determinamos materia grasa, proteínas, cenizas y humedad de las muestras de quesos, por lo tanto, podemos obtener por diferencia el contenido de hidratos de carbono presentes en las muestras. Además, como los quesos poseen más de $5 \%$ de materia grasa, la muestra debe desgrasarse antes de la titulación por el Método de Soxhlet. La muestra desgrasada se disolvió en agua destilada en matraz aforado de $100 \mathrm{~mL}$, se llevó 
a volumen con agua destilada y se filtró con papel de filtro Wathman $\mathrm{N}^{\circ} 1$ y se recogió el filtrado en un erlenmeyer de $250 \mathrm{~mL}$. Luego se tituló $10 \mathrm{ml}$ del reactivo FCB reemplazando la solución patrón de lactosa por el filtrado obtenido a partir de las muestras de las distintas formulaciones de quesos. Los resultados se expresan en \% de hidratos de carbono para los quesos sin fibra. Para los quesos adicionados con fibra dietaria se utilizó como patrón una solución de glucosa y se expresaron los resultados como \% de glúcidos reductores totales.

\subsubsection{Determinación del contenido de Sodio}

El contenido de sodio de los quesos se determinó mediante la metodología de Espectroscopía de Emisión Atómica, para ello se utilizó un fotómetro de llama donde la solución a analizar es atomizada en la llama del fotómetro. A la temperatura de la llama, las sales en solución se disocian y los iones llevados a su estado fundamental son excitados y emiten luz. Cada metal emite luz a longitudes de ondas específicas. La longitud de onda específica para un cierto metal es seleccionada por medio de un filtro. Esta luz es transformada en corriente eléctrica por una celda fotoeléctrica y la corriente es medida por un galvanómetro. Cuando en cada unidad de tiempo la misma cantidad de líquido es atomizada en la llama y cuando un porcentaje constante de átomos es excitado, existirá una relación entre la concentración de los átomos en la solución y la lectura del galvanómetro. Así, la concentración de los átomos del metal puede calcularse de las lecturas del galvanómetro, usando una curva estándar.

En este ensayo, a las muestras de las distintas formulaciones de quesos completamente mineralizadas (a cenizas blancas) se les adicionó $10 \mathrm{~mL}$ de ácido nítrico $\left(\mathrm{HNO}_{3}\right)$ 1:1, con el fin de diluir las cenizas. Luego se agitaron suavemente, cuidando de remover los restos de muestra adheridos a las paredes de los crisoles con varilla de vidrio y se esperó hasta que las muestras estuvieran disueltas. Las muestras disueltas fueron filtradas sobre matraces aforados de $50 \mathrm{~mL}$ utilizando papel Whatman $\mathrm{N}^{\circ} 1$, con el fin de traspasar la muestra en forma cuantitativa se adicionó repetidas veces $5 \mathrm{~mL}$ de $\mathrm{HNO}_{3}$ 1:1 al crisol, como lavado. El producto de este lavado fue adicionado al matraz hasta llegar al aforo. Finalmente, los $50 \mathrm{~mL}$ de disolución de muestra fueron almacenados en tubos plásticos falcon de $50 \mathrm{~mL}$, refrigerándolos hasta el momento de su lectura. El fotómetro de llama Arcano FP 640 (Hinotek Technology Co., China) se 
calibra solo con dos puntos mínimo y máximo, con agua bidestilada y solución patrón de sodio. Se inyecta agua bidestilada y se ajusta el cero de lectura con la perilla "low" 0 $\mathrm{K}$, luego se ajusta el máximo de lectura con solución patrón de $200 \mathrm{mg}$ de sodio (Na). Por último, se analizan las soluciones de las muestras de las diferentes formulaciones de quesos.

\subsubsection{Determinación del contenido de Calcio}

Para cuantificar el contenido de Calcio en los quesos se empleó en el método titulométrico con EDTA llamado 3500-Ca D. El EDTA (ácido etilendiaminotetraacetico) forma complejo con muchos metales tales como calcio y magnesio. Está reacción se emplea para determinar la cantidad de minerales en la muestra por titulación complejométrica. El calcio se determina directamente con EDTA cuando el $\mathrm{pH}$ es lo suficientemente alto para que precipite el magnesio como hidróxido. El final de la titulación se detecta usando indicadores que cambian de color cuando forman complejo con el calcio. En este trabajo de tesis, se utilizó como indicador el Azul Negro de Eriocromo R, cuyos colores de viraje son azul y rojo cuando forman complejo con el calcio. Se tiene el final de la titulación de la solución que contiene el calcio y el indicador, cuando ésta cambia de color rojo a azul (Nielsen, 2003) según la siguiente reacción general:

$$
\begin{array}{cc}
\text { Metal*Indicador }+ \text { EDTA } & \text { Metal*EDTA + Indicador } \\
(\text { rojo }) & (\text { azul })
\end{array}
$$

Para la determinación de calcio en quesos se prepara una solución acuosa de queso, pesando una cantidad necesaria para preparar una solución de concentración de 10-20 mg/100 mL. Para ello, se empleó como dato la concentración de calcio en leche de oveja que aparece en el trabajo de Balthazar y col. (2017). Para la titulación, a una porción de $50 \mathrm{~mL}$ de esta solución se adiciona con $2 \mathrm{ml}$ de $\mathrm{NaOH} 1 \mathrm{~N}$ o un volumen suficiente para producir un $\mathrm{pH}$ de 12 a 13. Se agitó y se añadieron 1 a 2 gotas del indicador. Desde la bureta graduada se va adicionando de a poco el EDTA 0,01M o 0,02 $\mathrm{N}(400,8 \mu \mathrm{g} \mathrm{Ca} / 1,00 \mathrm{~mL})$, agitando continuamente hasta el apropiado punto final, tomándose nota de los ml de EDTA gastados. Para obtener la concentración de Calcio 
en la solución que contiene la muestra de quesos, se realizan los cálculos según la siguiente ecuación.

$$
m g C a / L=\frac{A \times B \times 1000}{m L \text { de solución }}
$$

donde:

$\mathrm{A}=\mathrm{mL}$ de EDTA gastados en la titulación

$\mathrm{B}=\mathrm{mg}$ de $\mathrm{Ca}$ equivalentes a $1,00 \mathrm{~mL}$ de EDTA en el punto final del indicador para el Calcio $(400,8 \mu \mathrm{g})$

Los resultados fueron expresados como mg de Calcio/ $100 \mathrm{~g}$ de queso.

\subsubsection{Determinación de la composición de ácidos grasos}

Se trabajó con los lípidos extraídos por el método de solubilización de SchmidBondzynski-Ratzlaff (IDF 5/ ISO 1735:2004) indicado en el ítem 2.3.1.1.3. Los lípidos extraídos fueron saponificados con KOH 2M en metanol. Para ello, $200 \mathrm{mg}$ de muestra se pesaron dentro de un tubo de ensayo. Se agregó $4 \mathrm{~mL}$ de hexano para disolver la muestra agitando vigorosamente. Luego se agregó $200 \mu \mathrm{L}$ de solución metanólica de hidróxido de potasio y se agitó vigorosamente el tubo. Por último se agregó $1 \mathrm{~g}$ de sulfato de sodio anhidro a la solución y se agitó vigorosamente en vortex para neutralizar el hidróxido de potasio presente. La solución de hexano obtenida contiene los ésteres metílicos de los ácidos grasos (FAMEs).

El perfil de ácidos grasos se determinó por cromatografía gaseosa con columna capilar y fase estacionaria de alta polaridad (CGL). Se utilizó un cromatógrafo gaseoso Hewlett - Packard HP 6890 (USA) equipado con un detector de ionización de llama (FID), inyector Split y sistema integrador con adquisición de datos. Se inyectaron 0,5 $\mu \mathrm{L}$ de muestra. Los FAMEs se separaron usando una columna capilar Supelco 2560 (100 $\mathrm{m}$ de longitud, $0,25 \mathrm{~mm}$ de diámetro interno, 0,20 $\mu \mathrm{m}$ de espesor) con una rampa de temperatura de $100^{\circ} \mathrm{C}$ hasta $240^{\circ} \mathrm{C}$ a una velocidad de $3^{\circ} \mathrm{C} / \mathrm{min}$. La temperatura del detector de llama fue de $285^{\circ} \mathrm{C}$, utilizando helio como gas portador $(0.75 \mathrm{~mL} / \mathrm{min})$. La temperatura del inyector fue de $225^{\circ} \mathrm{C}$. La identificación de los picos se realizó por comparación con los tiempos de retención de ácidos grasos de referencia $(\mathrm{Nu}$ Check Prep, Inc., USA) preparados de igual forma que las muestras. La composición de ácidos 
grasos se expresó como porcentaje del total de ácidos grasos, realizando su análisis por duplicado con la colaboración de los profesionales del Instituto Biológico Dr. Tomas Perón (Ministerio de Salud de la Prov. de Bs. As.).

\subsubsection{Determinación del valor calórico}

Se determinó el valor calórico en kcal cada $100 \mathrm{~g}$ de producto, aplicando la convención internacional que establece que corresponden 4,02 kcal por g de proteínas, 3,87 kcal por g de hidratos de carbono y 9,00 kcal por g de lípidos (Coeficientes de Atwater).

\subsubsection{Evaluación de la microestructura}

Para examinar la microestructura de los quesos en el presente trabajo se utilizó microscopía láser confocal de barrido (CLSM). Esta técnica presenta la ventaja de que se puede visualizar y diferenciar los componentes del queso a través del uso de colorantes específicos para proteínas y lípidos. La capacidad de seccionamiento óptico de CLSM ha demostrado ser muy útil en el examen de muestras con alto contenido de grasa, que son difíciles de preparar usando la microscopía convencional sin la pérdida o la migración de los glóbulos de grasa (Ong y col., 2011).

La red proteica fue teñida usando el colorante fluorescente Fast Green (FG, Biopack, Argentina). Se preparó una solución de este fluorocromo en agua con una concentración de $0.01 \mathrm{~g}$ en $100 \mathrm{~mL}$. Se mezcló el queso con la solución a razón de 0,3 $\mathrm{mL}$ cada $0,8 \mathrm{~g}$ de proteína según Lutz y col. (2009). Los glóbulos de materia grasa fueron teñidos con el colorante fluorescente Nile Red (NR, Sigma-Aldrich, St Louis, USA). Para su uso se preparó una solución con etanol con una concentración de 0.02 mg de colorante / $\mathrm{mL}$ y se adicionó a la muestra, luego de agregar el Fast Green, en una proporción de $0,3 \mathrm{~mL}$ cada $1 \mathrm{~g}$ de materia grasa presente. Se mezcló la muestra para que los colorantes se difundan y se adhieran a las sustancias químicas que deseamos poner de manifiesto y luego se dejó reposar en oscuridad y a temperatura ambiente durante 30 min para que los solventes de los colorantes se evaporen antes de tomar las micrografías. Luego, pequeñas cantidades de las muestras fueron depositadas en 
portaobjetos, cubiertas con cubre objetos e invertidas en el equipo para la observación microscópica.

Las micrografías fueron obtenidas con el microscopio LEICA TCS SP5 Confocal Laser Scanning (Leica Microsystems, Baden- Württemberg, Germany). Los detectores de $\mathrm{He} / \mathrm{Ne}$ y de $\mathrm{Ar} / \mathrm{Kr}$ a una potencia de 30 y $20 \%$ fueron utilizados para los colorantes FG y NR, respectivamente. Las muestras de quesos fueron observadas con una lente de inmersión 63x (1.3 de apertura numérica) y con un zoom de 1.7. El colorante NR fue excitado a una longitud de onda de $488 \mathrm{~nm}$ y el colorante FG a $633 \mathrm{~nm}$. Los filtros de emisión fueron fijados a 555-585 nm para el colorante NR y a 660-710 nm para el colorante FG. Las imágenes digitales de los quesos con y sin homogeneizado, con y sin sal y con o sin fibras, se adquirieron con una resolución de 1.024 x 1.024 pixeles y se analizaron mediante el software LAS AF LITE (Leica Microsystems, BadenWürttemberg, Alemania).

Además, se llevó a cabo la observación microscópica de las fibras solas en forma de polvo, tal como se incorporaron a los quesos. Las fotomicrografías de todas las fibras se utilizaron para comparar con las fotomicrografías de los quesos con fibras. Se utilizó un Microscopio Electrónico de Barrido Ambiental (ESEM, Electroscan 2010, USA) utilizando un detector de electrones secundarios para trabajar en atmósfera gaseosa (GSED).

\subsubsection{Determinación de las propiedades mecánicas de los quesos elaborados}

La reología es el estudio del flujo y la deformación de la materia. En la ciencia de los alimentos este término puede ser intercambiable con el término textura, que se refiere a la deformación, al flujo y la desintegración de una muestra a la cual se le aplica una fuerza. Hablando estrictamente, la textura se utiliza para describir alimentos sólidos y la viscosidad (que es la tendencia a resistir el flujo) se utiliza para caracterizar alimentos líquidos. Sin embargo, muchos alimentos presentan ambas características sólidas y líquidas a la vez y la reología puede identificar adecuadamente ambas propiedades de estos alimentos (Tunick, 2000).

Para determinar que método reológico es apropiado para estudiar un alimento en particular se debe tener en cuenta ciertas características. En primer lugar el alimento debe ser en lo posible, homogéneo e isotrópico. Luego, teniendo en cuenta si el material 
es fluido (también llamado viscoso), sólido (elástico) o semisólido (viscoelástico) y utilizando la Figura 2.3 (Foegeding y col., 2003) que muestra el rango de consistencia del producto y sus correspondientes métodos de análisis más adecuados, se puede elegir la técnica a utilizar.

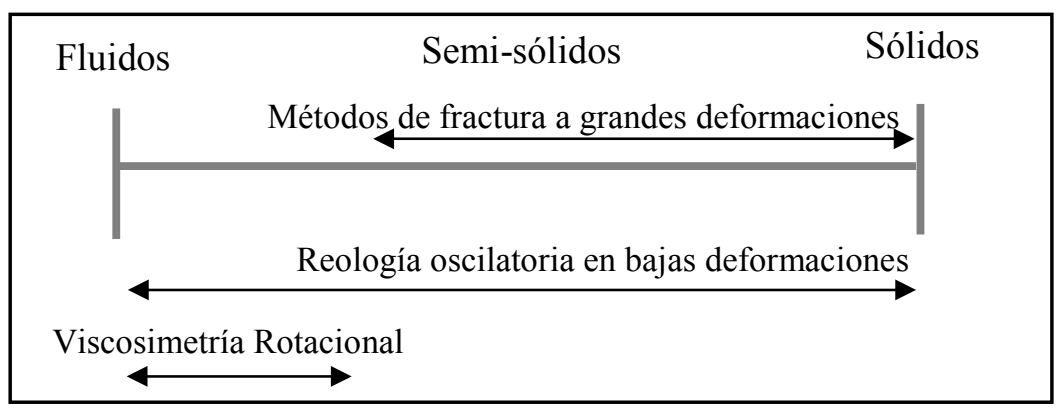

Figura 2.3 Métodos instrumentales para medir propiedades mecánicas según la consistencia del alimento.

Las propiedades reológicas de los quesos son tan importantes como las propiedades sensoriales. Los quesos no son enteramente isotrópicos u homogéneos y su comportamiento reológico depende del tiempo y de la velocidad de deformación usada, de la composición del queso, de la temperatura del ensayo y de la repetitividad de la geometría de la muestra utilizada. Por estas razones, todos los resultados reológicos deben ser interpretados con cautela (Tunick, 2000). Los quesos elaborados en este trabajo de tesis presentan consistencia semisólida, por lo tanto, se pueden emplear tanto los métodos oscilatorios a bajas deformaciones como los métodos en los cuales se aplican grandes deformaciones. Para comprender mejor el significado de estos métodos seleccionados, se puede considerar un perfil de esfuerzo vs deformación de un alimento semisólido o viscoelástico general (Figura 2.4).

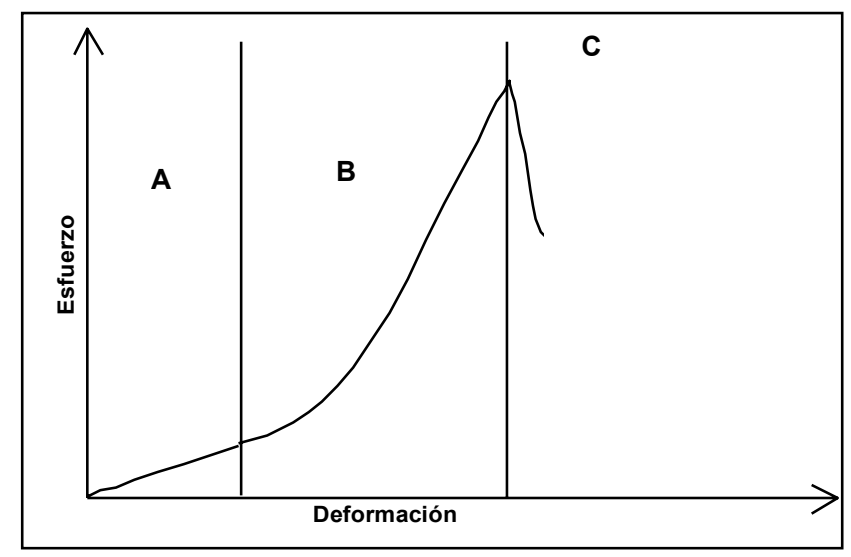

Figura 2.4 Regiones reológicas de los alimentos viscoelásticos 
La primera región es la lineal (A) donde la relación entre esfuerzo y deformación es directamente proporcional y se cumple la ley de Hooke. La siguiente región (B) es no lineal, donde la relación entre el esfuerzo y la deformación es más compleja. La última región (C) es aquella donde el alimento pierde irreversiblemente su estructura. Las regiones $\mathrm{A}$ y $\mathrm{C}$ han sido bien caracterizadas debido a la facilidad para recolectar e interpretar los datos en estas zonas. Sin embargo, para describir la respuesta sensorial durante la masticación de los alimentos, la región $\mathrm{B}$ no debe ser ignorada y puede contribuir significativamente al análisis de la textura (Foegeding y col., 2003).

Para determinar propiedades viscoelásticas en la región $\mathrm{A}$, se utilizan tanto ensayos oscilatorios dinámicos como estacionarios de compresión uniaxial. Los primeros consisten en la aplicación sobre el alimento de una deformación (en un reómetro de velocidad controlada) o de un esfuerzo (en un reómetro de esfuerzo controlado) que varía armónicamente con el tiempo midiéndose la respuesta del mismo (Steffe, 1996). En los ensayos de compresión uniaxial se aplica una fuerza normal a la muestra y se mide la deformación resultante (relación entre el cambio de altura con respecto a la altura original). Las regiones $\mathrm{B}$ y $\mathrm{C}$, son evaluadas usando metodologías con grandes deformaciones, midiendo compresión, tensión o torsión.

Los geles formados por las caseínas son responsables de las propiedades reológicas de casi todos los productos lácteos desde los quesos duros hasta en los quesos blandos y yogures (Tunick, 2000). Un gel es una red tridimensional continua de moléculas o partículas que engloba un gran volumen de una fase líquida continua, de forma muy similar a como lo hace una esponja. La red está constituida por moléculas de polímero unidas por enlaces covalentes y/o fuerzas débiles como: puentes de hidrógeno, asociaciones hidrofóbicas, fuerzas de Van der Waals, fuerzas iónicas, “entrecruzamientos al azar". La fase líquida es una solución acuosa de solutos de bajo peso molecular y porciones de las cadenas de polímero (Fennema, 2000).

Los geles poseen características tanto de los sólidos como de los líquidos. La estructura de la red tridimensional ofrece una resistencia significativa a las fuerzas aplicadas sobre ella, comportándose en ciertos aspectos como un sólido elástico. Sin embargo, la fase continua líquida, en la que las moléculas son completamente móviles, hace que el gel sea menos rígido que un sólido ordinario, lo que hace que se comporte en ciertos aspectos como un líquido viscoso. La consecuencia de todo ello es que un gel es un semisólido viscoelástico, lo que significa que la respuesta de un gel a las fuerzas 
que se aplican sobre él es en parte característica de un sólido elástico y en parte característica de un líquido viscoso (Fennema, 2000).

\subsection{Ensayo a bajas deformaciones}

En este trabajo de tesis se realizaron medidas oscilatorias dinámicas para evaluar las propiedades reológicas a bajas deformaciones y su relación con la microetructura de los quesos. Para realizar medidas oscilatorias dinámicas, en primer lugar, se debe establecer hasta donde llega el rango de viscoelasticidad lineal y trabajar dentro de él. Una respuesta viscoelástica lineal se obtiene cuando el esfuerzo o la deformación aplicada son lo suficientemente pequeños como para considerar que el material no ve afectado su estado de equilibrio (Kokini y col., 1995) y que las propiedades medidas son independientes de la deformación o esfuerzos aplicados. Para determinar éste rango, se realiza un barrido de deformación o esfuerzo a una frecuencia de oscilación $\omega$ (en $\mathrm{Hz}$ o rad/s) constante (Figura 2.5). Se considera como región de viscoelasticidad lineal hasta la deformación o esfuerzo correspondiente a la caída abrupta del módulo complejo G* (definido más adelante) que indica la pérdida total de la estructura del alimento.

Para estudiar las características estructurales del alimento, éste es sometido a una deformación o esfuerzo sinusoidal (dentro del rango lineal) a una determinada frecuencia de oscilación $\omega$ y se mide la respuesta del mismo (Figura 2.6). La muestra puede almacenar o disipar energía o ambas en forma de calor. Una sustancia puramente elástica almacenará toda la energía; mientras que un fluido viscoso ideal disipará y perderá la energía.

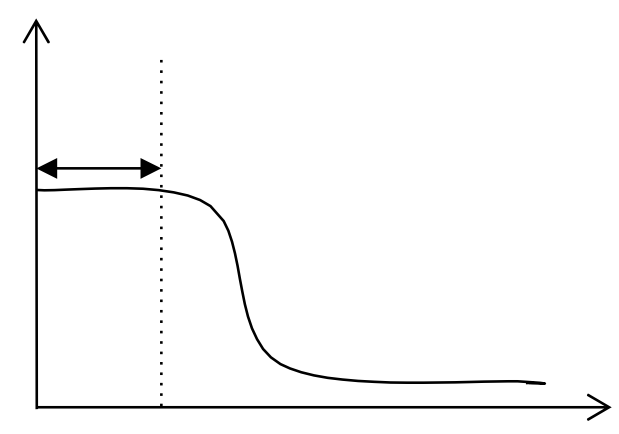

Figura 2.5 Barrido de deformación o esfuerzo a frecuencia $(\omega)$ constante. L: rango de viscoelasticidad lineal 


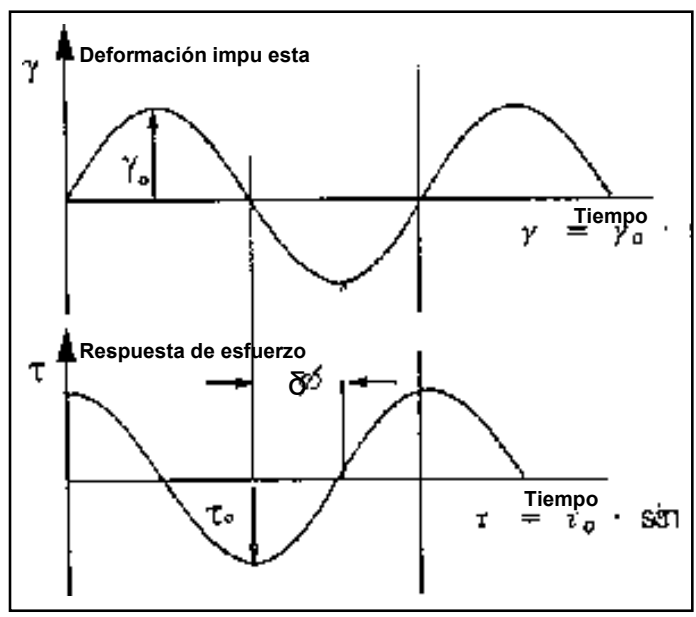

Figura. 2.6 Parámetros del ensayo dinámico a una determinada frecuencia de oscilación. A la deformación impuesta hay una respuesta de esfuerzo

El ángulo de desfasaje $(\delta)$, también llamado ángulo mecánico de pérdida es relativo a la deformación (Figura 2.6). Teniendo en cuenta que se cumple la ley de Hooke, la razón entre las amplitudes de esfuerzo y deformación implicados en el ensayo $\left(\sigma_{0} ; \gamma_{0}\right)$, es el módulo complejo, $\left(\mathrm{G}^{*}\right)$ :

$$
\mathrm{G}^{*}=\frac{\sigma_{0}}{\gamma_{0}}=\sqrt{\mathrm{G}^{\prime 2}+\mathrm{G}^{\prime 2}}
$$

Este módulo junto con el ángulo de fase, forman los dos términos viscoelásticos de interés: el módulo de almacenamiento $\left(G^{\prime}\right)$ y el módulo de pérdida $\left(G^{\prime \prime}\right)$ :

$$
\begin{aligned}
\mathrm{G}^{\prime} & =\mathrm{G}^{*} \cos (\delta) \\
\mathrm{G}^{\prime \prime} & =\mathrm{G}^{*} \operatorname{sen}(\delta)
\end{aligned}
$$

El módulo de almacenamiento refleja el grado en el cual un material almacena energía. Es el componente elástico. El módulo de perdida describe el grado de disipación de energía. Es el componente viscoso.

La relación entre la energía perdida y almacenada por ciclo es un importante parámetro conocido como tangente del ángulo de desfasaje $(\delta)$ o tangente de pérdida y describe el grado relativo de viscoelasticidad del alimento. Su relación con los módulos es:

$$
\tan \delta=\frac{\mathrm{G}^{\prime}}{\mathrm{G}^{\prime \prime}}
$$


En los ensayos dinámicos, típicamente se mide $G^{\prime}$ y $G^{\prime \prime}$ para un rango de frecuencia $\omega$ de interés y se obtiene el espectro mecánico de la muestra o la huella dactilar del comportamiento a bajas deformaciones del material, como también se lo 1lama. En la Figura 2.7 se pueden observar los tres comportamientos típicos de que se pueden encontrar cuando se estudian las propiedades dinámicas de un material viscoelástico. La Figura 2.7.a muestra la respuesta típica de una solución diluida de polímeros en donde G" es mayor que $G^{\prime}$ en todo el rango de frecuencias estudiadas y ambos módulos presentan una dependencia con la frecuencia, incrementándose cuando disminuye el tiempo de observación (mayor frecuencia).

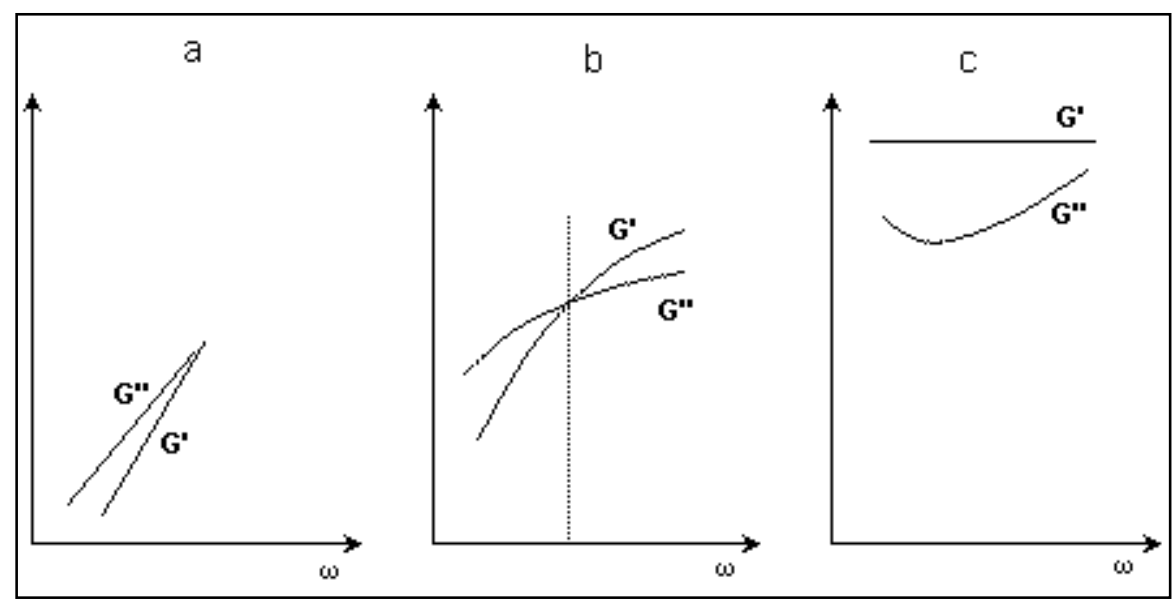

Figura 2.7 Respuestas oscilatorias típicas: a) solución diluida, b) solución concentrada, c) material con comportamiento tipo gel.

Esto significa que los movimientos moleculares ocurren dentro de la escala experimental de tiempo y que no existen interacciones con tiempos de vida más largos que el que dura la observación experimental. Si el material desarrolla una mayor característica elástica a medida que la frecuencia aumenta, se tiene el ejemplo típico de una solución concentrada de polímeros, donde G" y G' se cruzan para un determinado valor de frecuencia (Figura 2.7.b). Un gel presenta características elásticas dominantes ya que, G' es mayor que G" para todo el rango de frecuencias estudiadas. Además, G' no depende de la frecuencia y G" presenta un mínimo (Figura 2.7.c). Este tipo de comportamiento refleja la existencia de una red tridimensional con zonas de unión que poseen tiempos de vida más largos que el período de observación (Giboreau y col., 1994). 
En este trabajo de tesis se realizaron medidas oscilatorias dinámicas determinándose los valores de G', G" y tan $\delta$ con el reómetro Haake RS600 de esfuerzo controlado (Figura 2.8). En primer lugar se realizó un barrido de esfuerzo desde 1 a 50 $\mathrm{Pa}$ a una frecuencia constante de $1 \mathrm{~Hz}$ y a $25 \pm 1{ }^{\circ} \mathrm{C}$, para determinar el rango de viscoelasticidad lineal. Se empleó un sensor plato-plato de superficie rugosa PP35 que previene el deslizamiento de la muestra, que impide una buena medición. La separación entre los platos fue de $1 \mathrm{~mm}$. Luego, los quesos con y sin fibra dietaria se sometieron a un barrido de frecuencia desde $0.01592 \mathrm{~Hz}$ hasta $15.92 \mathrm{~Hz}$, con un esfuerzo constante de $10 \mathrm{~Pa}$ a una temperatura de $25 \pm 1^{\circ} \mathrm{C}$. Se compararon los valores de G', G" y $\tan \delta$ a $1 \mathrm{~Hz}$ expresados como los valores medios \pm error estándar de la media de dos repeticiones de la misma formulación.

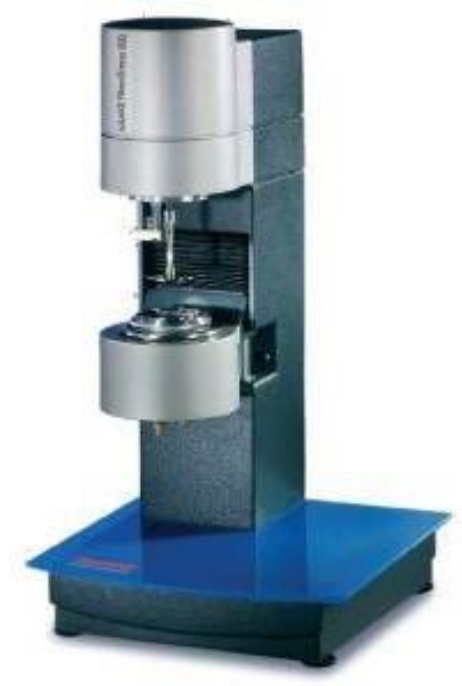

Figura 2.8 Reómetro Haake RS600 con la geometría plato-plato, utilizado para analizar los quesos.

\subsection{Ensayo a grandes deformaciones}

Las metodologías instrumentales con grandes deformaciones miden compresión, tensión o torsión. Entre los ensayos de compresión se encuentran los de penetración, compresión con una esfera, compresión-extrusión a través de uno o varios orificios y los de compresión-extrusión a través de un anillo (Tunick, 2000). Los quesos elaborados en este trabajo de tesis son del tipo de los que se consumen mayoritariamente siendo untados sobre otro alimento sólido como por ejemplo galletitas o panes. Por lo tanto, es necesario que fluyan cuando se les aplica una fuerza pequeña para ser extendidos sobre 
otra superficie; pero también es deseable que no sean completamente líquidos y tomen la forma del recipiente que los contiene (Tawongsa y col., 2014). Es decir que la untabilidad es una de sus características reológicas y sensoriales más específica (Mónaco y col., 2008). En particular, el ensayo de compresión-extrusión a través de un anillo es unos de los ensayos más adecuados para este producto porque es especialmente útil con materiales que tienen la consistencia de una pasta y/o con suspensiones de partículas. Un viscosímetro rotacional no puede usarse para estudiar estos fluidos grumosos porque se obtienen lecturas de torque pulsantes (Gurjal y Sodhi, 2002). Debido a la capacidad del ensayo de compresión-extrusión simple o por anillo de medir y caracterizar con precisión y rapidez la textura de los productos semisólidos, la industria alimentaria puede establecer estándares de calidad y monitorear el deterioro durante el almacenamiento y la distribución de sus productos. Además, su simplicidad, el tiempo relativamente corto y el bajo costo requerido para realizar esta prueba la convierten en una técnica adecuada para el control de calidad y el desarrollo de nuevos productos (Tawongsa y col., 2014; Ramaswamy y col., 2015). Este ensayo (Figura 2.9) consiste en dos movimientos físicos: (a) un émbolo cilíndrico comprime hacia abajo la muestra y (b) la muestra fluye hacia arriba a través del espacio anular concéntrico generado por la geometría de este dispositivo, ya que la muestra está contenida en una copa cilíndrica.

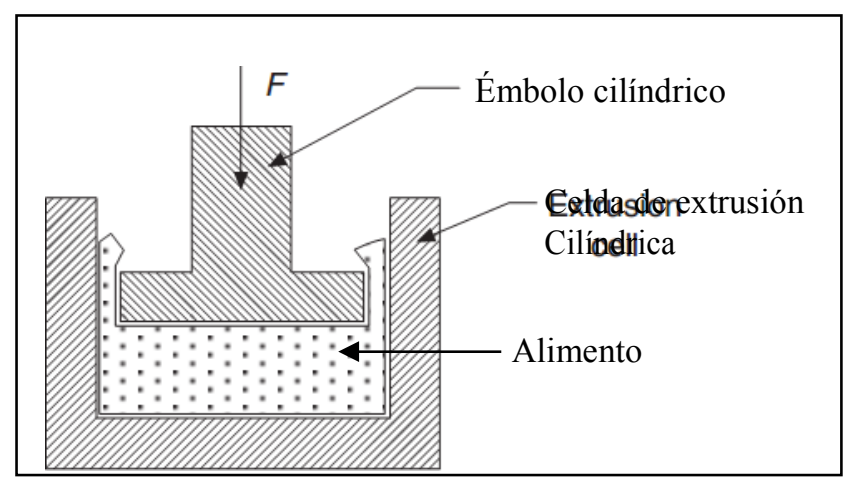

Figura 2.9 Vista lateral del dispositivo para compresión-extrusión por anillo o simple

El alimento es comprimido hasta que su estructura semisólida se pierde y comienza a fluir a través del anillo. Típicamente, en este ensayo se mide la fuerza requerida para extruir la muestra en la dirección opuesta a la del émbolo (Bourne 2002; Gurjal y Sodhi, 2002; Tawongsa y col., 2014; Ramaswamy y col., 2015).

Para esta prueba en este trabajo de tesis se utilizaron recipientes plásticos $(57 \mathrm{~mm}$ 
de diámetro x $48 \mathrm{~mm}$ de alto) en los cuales fueron envasados los quesos hasta $30 \mathrm{~mm}$ de altura. Se utilizó el equipo texturómetro (Figura 2.10) Texture Analyser TA-xT2i (Stable Micro Systems, Reino Unido) con un émbolo con disco en el extremo de $40 \mathrm{~mm}$ de diámetro que contactaba la muestra. Esta sonda comprimió los quesos por el centro del recipiente hasta $15 \mathrm{~mm}$ de espesor con fuerza y velocidad constante $(0,98 \mathrm{~N}$ y 1 $\mathrm{mm} / \mathrm{s}$ ), formándose un anillo de $17 \mathrm{~mm}$ de ancho. Se recolectaron por duplicado los datos de fuerza $[\mathrm{N}]$ vs tiempo [s] para los quesos con y sin homogeneizar, con y sin sal, con y sin fibras. Se graficaron los perfiles de fuerza de cada muestra de queso y de ellos se obtuvo el parámetro umbral de fluencia. El ensayo se realizó a temperatura ambiente $\left(25 \pm 1^{\circ} \mathrm{C}\right)$ que es la temperatura a la cual se consume este alimento.

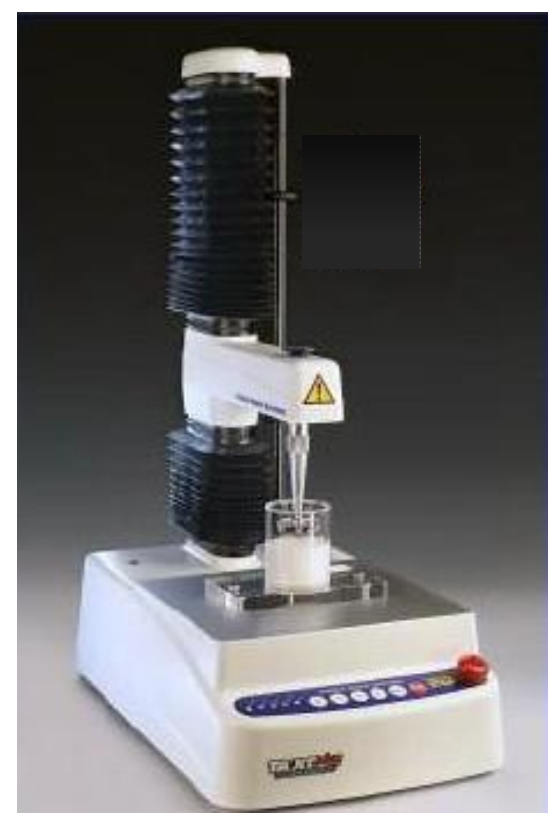

Figura 2.10 Texturómetro Stable Micro Systems con celda de compresión-extrusión simple

\subsubsection{Evaluación sensorial de aceptabilidad general}

Se realizó una prueba de aceptabilidad del producto con 30 evaluadores semientrenados (20 mujeres y 10 varones) elegidos entre el personal del Instituto (CIDCA) mediante la realización de una encuesta previa donde se seleccionaron aquellas personas consumidoras habituales de queso untable (Figura 2.11). 


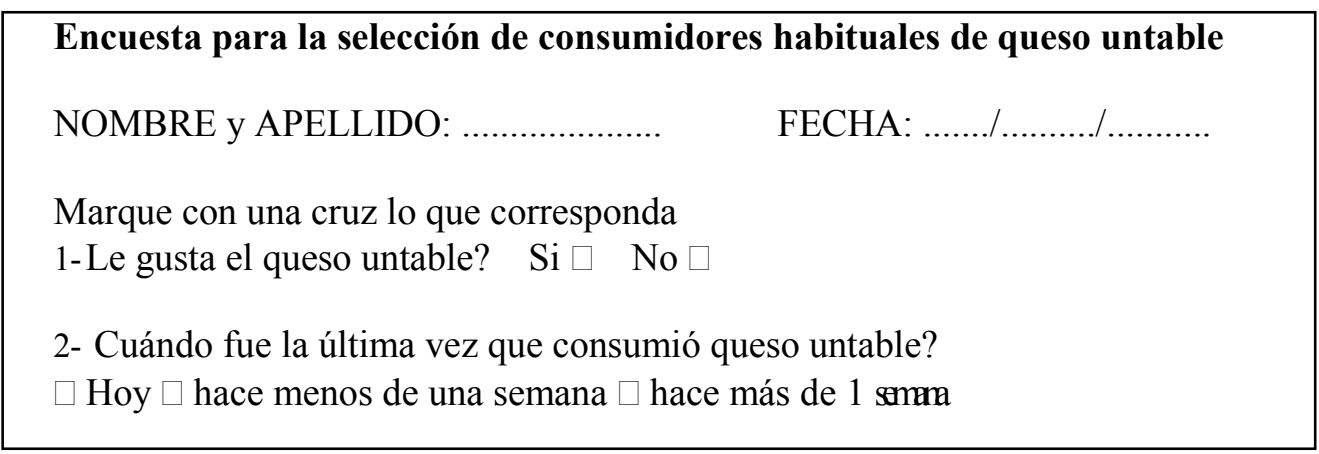

Figura 2.11 Planilla utilizada para la selección de consumidores habituales de queso untable

El ensayo hedónico consistió en evaluar aceptabilidad general, color, textura, untabilidad y sabor, en una escala no estructurada del 1 al 9. En la Figura 2.12 se muestra la planilla utilizada. Cada muestra se colocó en un recipiente de plástico rotulado con un número de 3 cifras elegidas al azar. Se presentó a cada evaluador una bandeja que contenía cinco muestras correspondientes a los quesos con y sin fibras dentro de sus recipientes codificados, ordenadas visualmente en forma aleatoria para cada evaluador. Se realizaron cuatro sesiones de cata separadas entre sí por 30 días, durante la mañana a partir de las $10 \mathrm{~h}$ que correspondieron a: quesos sin homogeneizar sin sal, quesos sin homogeneizar con sal, quesos homogeneizados sin sal, y quesos homogeneizados con sal. El horario del día se eligió teniendo en cuenta que este tipo de queso se consume en nuestra población como desayuno, colación o merienda.

\begin{tabular}{|c|c|c|c|c|c|c|c|c|c|}
\hline \multicolumn{10}{|c|}{ ACEPTABILIDAD SENSORIAL DE QUESOS UNTABLES } \\
\hline \multirow{2}{*}{\multicolumn{10}{|c|}{ 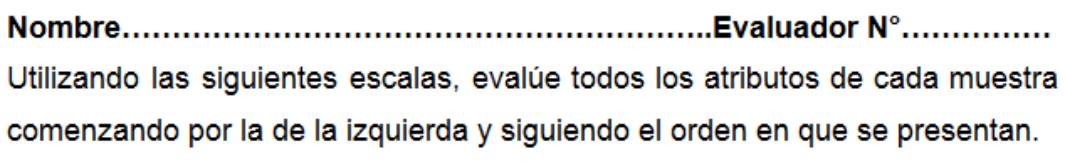 }} \\
\hline & & & & & & & & & \\
\hline \multicolumn{10}{|l|}{ Muestra $\mathrm{N}^{\circ} \ldots \ldots \ldots \ldots$} \\
\hline \multicolumn{6}{|c|}{ Me desagrada mucho } & \multicolumn{4}{|c|}{ Me agrada mucho } \\
\hline Aceptabilidad general & $\sqcup$ & $\sqcup$ & $\sqcup$ & $\sqcup$ & $\sqcup$ & $\sqcup$ & $\sqcup$ & $\sqcup$ & $\sqcup$ \\
\hline Color & $\sqcup$ & $\sqcup$ & $\sqcup$ & $\sqcup$ & $\sqcup$ & $\sqcup$ & $\sqcup$ & $\sqcup$ & $\sqcup$ \\
\hline Textura & $\sqcup$ & $\sqcup$ & $\sqcup$ & $\sqcup$ & $\sqcup$ & $\sqcup$ & $\sqcup$ & $\sqcup$ & $\sqcup$ \\
\hline Untabilidad & $\sqcup$ & $\sqcup$ & $\sqcup$ & $\sqcup$ & $\sqcup$ & $\sqcup$ & $\sqcup$ & $\sqcup$ & $\sqcup$ \\
\hline Sabor & $\sqcup$ & $\sqcup$ & $\sqcup$ & $\sqcup$ & $\sqcup$ & $\sqcup$ & $\sqcup$ & $\sqcup$ & $\sqcup$ \\
\hline
\end{tabular}

Figura 2.12 Planilla utilizada para el análisis de aceptabilidad sensorial para una sola muestra de queso, a modo de ejemplo. 


\subsubsection{Análisis estadístico}

Con el objetivo de estudiar el efecto de la adición de sal y de fibras de distinto origen, así como también la incorporación de una etapa de homogeneización en los quesos de leche ovina recién elaborados, se utilizó un diseño experimental factorial completamente aleatorizado. Este diseño es útil cuando diversos factores pueden afectar las características del producto final. En virtud de ello, en forma simultánea, puede estudiarse cuál es la influencia de cada uno de los factores, variando los niveles de los restantes (Wu y Hammada, 2000). Los factores estudiados y sus respectivos niveles fueron los siguientes:
a) Adición de sal: nivel 1: con sal y nivel 2: sin sal
b) Tipo de fibra: 1(QSF), 2(QFB), 3(QFT), 4(QFI) y 5(QFP)
c) Homogeneización: nivel 1: con y nivel 2: sin

\subsubsection{Evaluación de la calidad de los quesos funcionales elaborados durante el almacenamiento congelado}

Se utilizó la congelación como forma de preservación de los quesos elaborados y se estudió el efecto de ésta en la calidad de los quesos almacenados. Las muestras se mantuvieron en una cámara de congelación (Arce Refrigeración, Arg) a -20 $\pm 1{ }^{\circ} \mathrm{C}$ en oscuridad durante 90 días desde su manufactura. En la actualidad, los quesos untables se comercializan en nuestro país tanto en envases plásticos autosustentables de forma cónica truncada, como en envases plásticos flexibles con forma de bolsa (Figura 2.13). Por lo tanto, se emplearon estos distintos tipos de envase en los ensayos realizados. Para llevar a cabo las distintas determinaciones cada 15 días, se extrajeron los quesos de la cámara de frío la tarde anterior al día del ensayo y se descongelaron a $8 \pm 1{ }^{\circ} \mathrm{C}$ en heladera (Gafa, Argentina) hasta el momento del ensayo. La descongelación lenta y a temperatura de refrigeración evita alteraciones organolépticas del producto. 

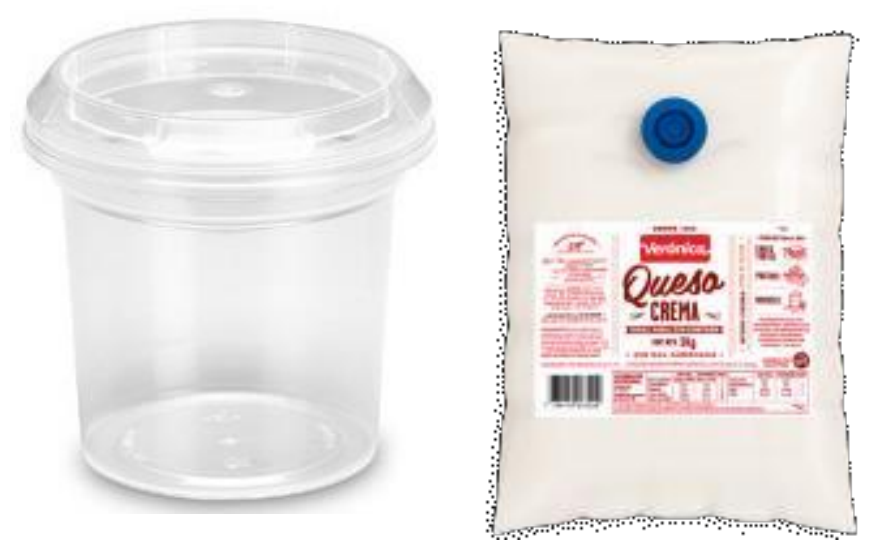

Figura 2.13 Tipos de envases plásticos de queso untables utilizados en nuestro país. a) autosustentable cilíndrico y b) flexible en forma de bolsa

\subsubsection{Medición de pH}

Se realizaron las mediciones de $\mathrm{pH}$ de los quesos elaborados y envasados en recipientes plásticos cilíndricos autosustentables. Se utilizó un peachimetro Hach, modelo EC-30 (USA) con un electrodo de punta de vidrio, de Broadley James Corporation (USA). Las medidas se realizaron por duplicado.

\subsubsection{Cuantificación del suero liberado}

Los geles formados por adición del cuajo a la leche en condiciones de reposo, pueden mostrar posteriormente sinéresis, es decir, expulsar líquido (suero), mientras que el gel (cuajada) se contrae. La sinéresis es acompañada por una reorganización de la red de proteínas. La velocidad y el grado de sinéresis o liberación de suero, tienen un importante rol en la determinación de algunos atributos finales del queso como su vida útil (Mateo y col., 2009). Es por eso que se determinó la liberación de suero en los distintos quesos con y sin fibra, para evaluar el efecto de la adición de las diferentes fibras a los quesos durante el almacenamiento.

Las distintas muestras se colocaron en tubos falcon de $50 \mathrm{~mL}$ con tapa a rosca para realizar la medida de exudado. Se pesaron $20 \pm 1 \mathrm{~g}$ en cada tubo. Se realizaron medidas por duplicado cada 15 días durante 3 meses de almacenamiento a $-20 \pm 1{ }^{\circ} \mathrm{C}$ en cámara. Para medir el exudado producido, las muestras previamente descongeladas se centrifugaron en el mismo tubo a $900 \mathrm{rpm}$ por 5 minutos en centrífuga Labour modelo 
800D, de bajas revoluciones (Schönfeld, China). Se midió el volumen de suero liberado y se expresó como $\mathrm{mL}$ de suero/g de queso.

\subsubsection{Estudio de la microestructura}

El estudio de la microestructura se llevó a cabo en las mismas condiciones que las empleadas en la sección de evaluación de los productos terminados en el punto 2.3.1.3 observando los preparados de los quesos durante el almacenamiento congelado. Para ello, las muestras envasadas en recipientes plásticos cilíndricos autosustentables se descongelaron en refrigeración $\left(8 \pm 1^{\circ} \mathrm{C}\right)$ antes de realizar la observación microscópica.

\subsubsection{Evaluación instrumental de la textura}

La evaluación instrumental de la textura durante el almacenamiento congelado se realizó mediante el ensayo de compresión-extrusión utilizado para estudiar la calidad de los quesos recién elaborados en las mismas condiciones que las descriptas en el ítem 2.3.1.4.2.

\subsubsection{Determinación de la estabilidad de los lípidos durante el almacenamiento}

Los lípidos son macromoléculas importantes de los alimentos desde el punto de vista nutricional y también porque contribuyen al sabor, a la textura y a la palatabilidad de los mismos (Pegg R. B., 2001). Los principales componentes lipídicos de los alimentos son los triacilgliceroles, los cuales se denominan comúnmente como grasas o aceites. Sin embargo, los lípidos pueden degradarse químicamente durante el almacenamiento, contribuyendo a determinar la vida útil de los alimentos que los contienen. Esta degradación puede ocurrir en primer lugar mediante la acción de las lipasas. En particular, la leche posee lipasas lipoproteicas que pueden atacar la superficie del glóbulo de grasa, pero se inactivan con la pasteurización (Badui Dergal, 2006). Sin embargo, también pueden actuar las lipasas microbianas termorresistentes, producidas por microorganismos capaces de crecer a temperaturas de refrigeración. Estas enzimas endógenas o exógenas al alimento liberan ácidos grasos libres que si son insaturados y se encuentran en presencia de oxígeno, pueden sufrir degradación 
oxidativa (Juárez Iglesias, 1999).

La oxidación de lípidos es un tipo de deterioro que puede afectar la calidad de los productos lácteos procesados, en especial aquellos que son almacenados durante largos periodos de tiempo y que contienen grandes proporciones de agua y materia grasa (Webb y Arbuckle, 1977; O'Connor y O’Brien, 2011). En el caso de los quesos desarrollados en este trabajo de tesis que se almacenan congelados en oscuridad, en envases plásticos que los contienen, el mecanismo de oxidación de lípidos más probable que ocurra involucra la autooxidación de los lípidos insaturados. Esta transformación química tiene diferentes etapas que se suceden una después de la otra, como la formación de radicales libres, hidroperóxidos (productos primarios de oxidación incoloros e inodoros) y finaliza con la aparición de los productos secundarios de oxidación que se forman mediante la escisión, el reordenamiento y la combinación de las sustancias de oxidación primarias (Frankel, 2005). Estas reacciones llevan a la formación de compuestos carbonílicos volátiles responsables de sabores no deseados, aún en almacenamiento congelado ya que las enzimas pueden seguir activas (Zhang y col., 2006). Sin embargo, se han registrado casos en los cuales se han almacenado en congelación quesos de alta humedad y materia grasa con mínimo deterioro (Webb y Arbuckle, 1977), por lo tanto, es importante el estudio de la estabilidad de los lípidos durante el almacenamiento congelado de los quesos desarrollados.

En este trabajo de tesis, la oxidación de lípidos durante el periodo de almacenamiento fue monitoreada mediante la determinación de los productos de oxidación secundarios. Para ello, se cuantificaron las sustancias reactivas al ácido 2tiobarbitúrico (TBARS). Teniendo en cuenta que en ensayos previos, se produjeron interferencias con los carbohidratos presentes en las muestras de quesos adicionadas con fibra dietaria de distintos orígenes, se procedió a realizar una extracción de los lípidos presentes en los quesos elaborados antes de realizar estos dos ensayos para cada tiempo de almacenamiento analizado. A su vez, se evaluó el seguimiento de la oxidación lipídica en dos envases diferentes, uno utilizando un envase de polietileno de baja densidad, cuya permeabilidad al oxígeno es $6.898 \mathrm{~cm}^{3} /\left[\mathrm{m}^{2}\right.$ - día $]$ y otro utilizando envase plástico BK1 cuya permeabilidad reducida al oxígeno es $152 \mathrm{~cm}^{3} /$ [ $\mathrm{m}^{2}$ - día].

La extracción de la materia grasa se realizó mediante la técnica de solubilización que es el método de Schmid-Bondzynski-Ratzlaff (IDF 5/ ISO 1735:2004). Se utilizaron dos muestras de cada formulación y tiempo de almacenamiento. Para ello, se pesó alrededor de $8 \mathrm{~g}$ de queso de cada muestra en balanza analítica, se agregó $10 \mathrm{~mL}$ 
de ácido clorhídrico concentrado y se mezcló para que se desintegre la estructura del queso. Se trasvasó a una probeta esmerilada y se agregó 50-60 mL de éter lavando el vaso donde estaba el queso para arrastrar toda la muestra con dos porciones de $10 \mathrm{~mL}$ de alcohol etílico. Se agitó 20 veces por inmersión la probeta tapada. Se dejó media hora en reposo y luego se extrajeron $20 \mathrm{~mL}$ de éter de cada muestra y se colocaron en vasos de precipitados previamente rotulados y pesados. Se evaporó el éter toda la noche en oscuridad y sin calor hasta el día siguiente. Se pesó nuevamente para obtener por diferencia la cantidad de lípidos extraídos.

La oxidación de lípidos durante el periodo de almacenamiento fue monitoreada mediante la determinación de sustancias reactivas al ácido 2-tiobarbitúrico (TBARS) utilizando el método directo (Pegg, 2001). La reacción se basa en la formación de un compuesto de color rosado entre el ácido 2-tiobarbitúrico y el malonaldehído, de acuerdo a la reacción que se muestra en la Figura 2.14. La determinación espectrofotométrica se realizó a $532 \mathrm{~nm}$ y los valores de absorbancia se utilizaron para calcular el $\mathrm{N}^{\mathrm{o}}$ de TBA expresado como mg equivalentes de malonaldehído (MDA) por $\mathrm{kg}$ de producto (mg MDA/kg queso).<smiles>CC=CC(=O)CC=O</smiles>

ácido 2-tiobarbitúrico

malonaldehído<smiles>O=c1[nH]c(=S)[nH]c(O)c1/C=C/C=C/c1c(O)[nH]c(=S)[nH]c1=O</smiles>

aducto

Figura 2.14 Reacción entre el ácido 2-tiobarbitúrico y el malonaldehído (Shahidi, 1997)

En el método directo se utiliza butanol como medio de reacción. Para ello, se agrega $10 \mathrm{~mL}$ de butanol (Sigma, Argentina) en el vaso de precipitados que contiene los lípidos extraídos de las muestras de quesos, se agita para resuspender y diluir la materia grasa depositada y se filtra para obtener una solución límpida.

Para preparar la solución de TBA que se utiliza en la reacción de color se pesó 0,1 g de TBA (Sigma Aldrich) en un vaso de precipitados de $100 \mathrm{~mL}$ y se agregó aproximadamente $40 \mathrm{~mL}$ de butanol, se agitó y se sonicó. Luego se filtró para obtener una solución límpida y se enrazó en un matraz de $50 \mathrm{~mL}$. Para la reacción de color se tomó $2 \mathrm{~mL}$ de las muestras en tubos de ensayo rotulados, luego se agregó $2 \mathrm{~mL}$ de solución de TBA. Se llevó a baño a $90^{\circ} \mathrm{C}$ por $2 \mathrm{~h}$. Para el blanco se colocó $2 \mathrm{~mL}$ de 
butanol y $2 \mathrm{~mL}$ de solución de TBA en un tubo de ensayo. Se midió la absorbancia a $532 \mathrm{~nm}$ y se calculó el contenido de MDA teniendo en cuenta la curva patrón realizada. Para la confección de esta curva se preparó una solución patrón de MDA en butanol y se realizaron varias diluciones, luego se llevó a cabo la reacción de color, del mismo modo que para las muestras a analizar y se midió la absorbancia también a $532 \mathrm{~nm}$ en espectrofotómetro Shimadzu UV-mini 1240 (Kyoto, Japón).

\subsubsection{Evaluación sensorial de aceptabilidad general}

La evaluación de la aceptabilidad sensorial se llevó a cabo de la misma manera que para el estudio de la calidad de los quesos recién elaborados detallado en el ítem 2.3.1.5 al final del almacenamiento congelado, es decir a los tres meses, para no fatigar a los jueces no entrenados que integraron el panel con pruebas a tiempos intermedios de almacenamiento congelado.

\subsubsection{Análisis estadístico}

Se utilizó el mismo diseño que en la caracterización de los quesos recién elaborados con un factor más que es el tiempo de almacenamiento congelado, cuyos niveles fueron: $1(\mathrm{t}=1 \mathrm{~d}), 2(\mathrm{t}=15 \mathrm{~d}), 3(\mathrm{t}=30 \mathrm{~d}), 4(\mathrm{t}=45 \mathrm{~d}), 5(\mathrm{t}=60 \mathrm{~d}), 6(\mathrm{t}=75 \mathrm{~d})$ y 7 $(\mathrm{t}=90 \mathrm{~d})$.

Se empleó el software Systat 12.0 (SYSTAT Inc., 1992, USA) para el análisis estadístico de los resultados obtenidos. Se realizaron los análisis de varianza (ANOVA) para determinar si hubo o no diferencias significativas entre los quesos con y sin fibra y los distintos tiempos en los ensayos de almacenamiento. Además, se utilizó el test de Fisher para la comparación de medias, con un nivel de significación de $\alpha=0.05$. 


\section{CAPÍTULO 3}

\section{RESULTADOS Y DISCUSIÓN}




\subsection{Evaluación del producto terminado}

\subsubsection{Rendimiento quesero}

En la Tabla 3.1 se pueden observar los rendimientos obtenidos para cada elaboración de queso que se llevó a cabo para realizar los ensayos de este trabajo de tesis. El rendimiento quesero promedio fue de 59,24 $\pm 3,39 \%$.

Tabla 3.1 Rendimiento quesero de cada producción y su promedio general

\begin{tabular}{|c|c|c|c|}
\hline $\mathrm{N}^{\text {ro }}$ de lote & $\begin{array}{c}\text { Peso del queso obtenido } \\
(\mathbf{k g})\end{array}$ & $\begin{array}{l}\text { Volumen de leche } \\
\text { (l) }\end{array}$ & Rendimiento (\%) \\
\hline 1 & 3.81 & 6.65 & 57.29 \\
\hline 2 & 3.85 & 7.12 & 54.07 \\
\hline 3 & 3.33 & 5.97 & 55.78 \\
\hline 4 & 3.22 & 5.90 & 54.58 \\
\hline 5 & 3.09 & 5.60 & 55.18 \\
\hline 6 & 3.12 & 5.50 & 56.73 \\
\hline 7 & 4.107 & 6.80 & 60.40 \\
\hline 8 & 3.666 & 6.30 & 58.19 \\
\hline 9 & 4.343 & 6.90 & 62.94 \\
\hline 10 & 3.793 & 6.28 & 60.40 \\
\hline 11 & 3.79 & 5.90 & 64.24 \\
\hline 12 & 3.57 & 5.60 & 63.75 \\
\hline 13 & 3.41 & 5.76 & 59.20 \\
\hline 14 & 3.99 & 6.30 & 63.33 \\
\hline 15 & 3.79 & 6.28 & 60.35 \\
\hline 16 & 3.11 & 5.07 & 61.34 \\
\hline Promedio & & & 59.24 \\
\hline Desvío estándar & & & 3.39 \\
\hline
\end{tabular}

El rendimiento quesero se ve directamente influenciado por la composición química de la leche, especialmente en sus constituyentes principales, lípidos y proteínas, que son los componentes que determinan su valor como materia prima para la 
fabricación de queso. Además, influyen la humedad final del queso y las pérdidas que pueden producirse durante el proceso de elaboración (Marti y col., 2000). La leche de oveja al presentar mayor cantidad de proteína y materia grasa que la leche de vaca, ofrece un rendimiento quesero mayor utilizando la misma cantidad de leche, por lo que es una opción muy rentable para la elaboración de queso. La composición media de la leche de oveja es de $19,18 \%$ de solidos totales, constituidos a su vez por proteínas $(6,73$ \%) y lípidos (7,44\%), entre otros componentes (Busetti, 2006a). Comparativamente la leche de vaca presenta valores menores, tanto de sólidos (12\%) como de proteínas $(3,2$ $\%)$ y materia grasa $(3,4 \%)$.

A su vez, el rendimiento puede variar según la temporada, la raza, la dieta y la condición del animal del cual se obtuvo la leche (Suarez, 1999). La grasa es la fracción láctea que más variación experimenta, desde 5,70\% en el mes de Octubre hasta 11,40\% en el mes de Mayo. En la Figura 3.1 se observa la variación porcentual de los distintos componentes de la leche de oveja durante los meses de septiembre y junio (Busetti, 2006b).

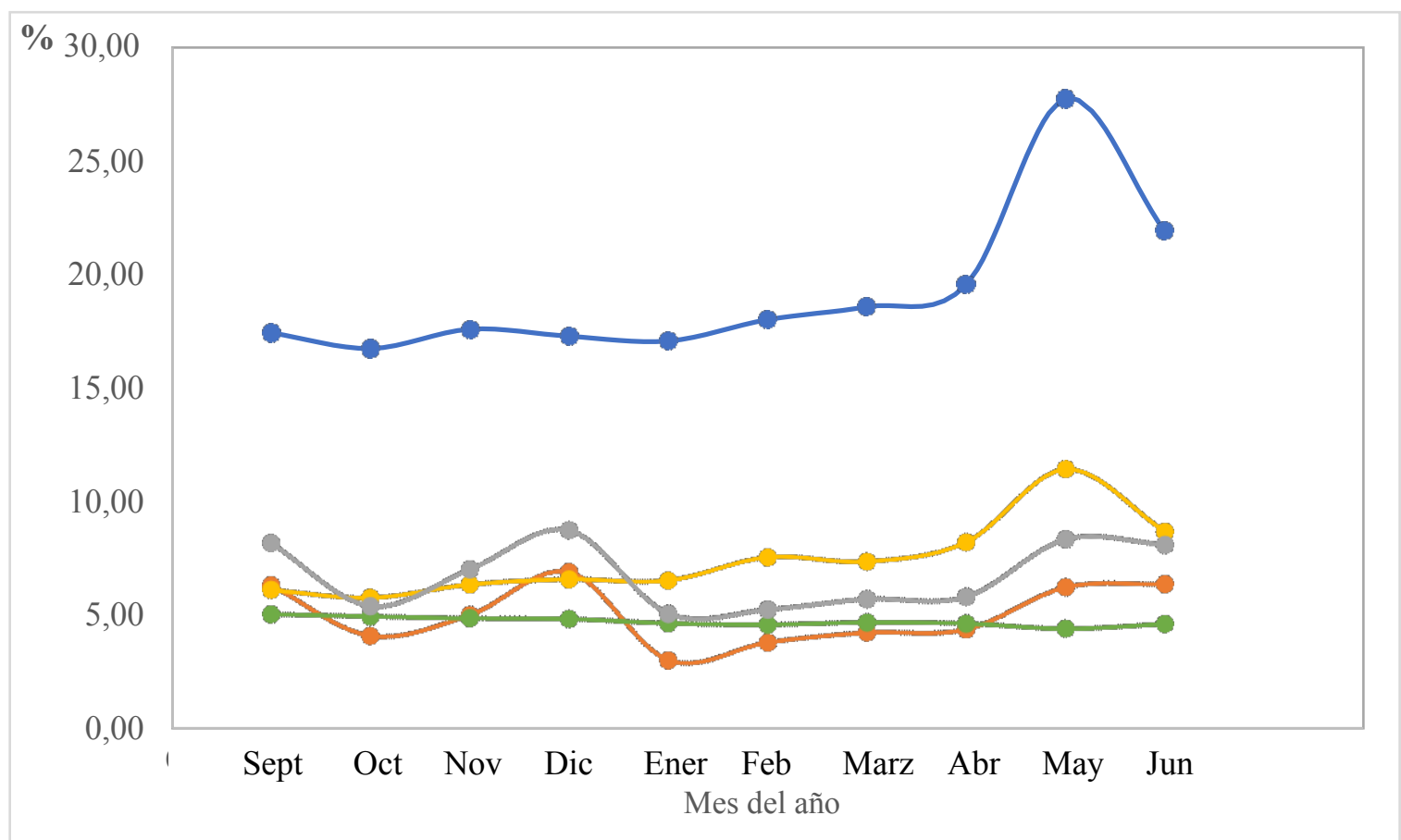

Figura 3.1 Variación porcentual anual en la composición de la leche de oveja. Extracto Seco $\square$ Caseína $\square$ Proteína $\square$ Materia Grasa $\square$ Cenizas

Algunas variaciones en el proceso, como la forma de realizar la coagulación y el desuerado, determinan el contenido de agua en el producto final, y por ende en el rendimiento final del queso. Si se aumenta el tiempo de coagulación, se obtiene una 
cuajada más firme, capaz de retener mayor cantidad de agua y se obtienen quesos de mayor humedad y rendimiento. El desuerado también influye en el porcentaje de humedad, ya que a mayor desuerado, menor humedad en el queso y menor el rendimiento final obtenido.

Debido a la variabilidad en la materia prima, que no solo se modifica estacionalmente, sino que también se ve afectada por otros factores como: climáticos, de transporte, tiempo de almacenamiento, etc., sumado a variaciones en el proceso que pueden ser controlados casi en todas las fábricas lácteas por el "maestro quesero", llevan a un valor de rendimiento variable, dentro de un rango de tolerancia. Es decir, en todas las fábricas elaboradoras de quesos, tanto el valor de humedad final como el rendimiento no son valores fijos, sino que tienen una variación relevante entre los distintos lotes de fabricación. Esta variación puede disminuirse trabajando sobre la estandarización de la leche y automatizando el proceso de elaboración, asegurando repetitividad en el trabajo del operador de tina. Si no se asegura una estandarización rigurosa de la materia prima, hay dos puntos en las elaboraciones queseras que dependen exclusivamente del operador, que son, la firmeza en la cuajada antes del corte y el momento de finalización de la elaboración (fin de secado o cocción). Por lo cual, la mayoría de la plantas elaboradoras de quesos que tienen sus procesos de tinas automatizados, igualmente, deben dejar estas dos etapas de la elaboración (fin coagulación y fin de elaboración) a criterio del "maestro quesero".

\subsubsection{Composición centesimal}

En la Tabla 3.2 se presentan los resultados obtenidos para la composición porcentual de los quesos manufacturados con variaciones en el proceso: homogeneizado y $\sin$ homogeneizar y con sal y sin sal. Asimismo, en la Tabla 3.3 se observa la composición porcentual de los quesos a los cuales se le adicionaron las diferentes fibras: fibra de bambú, fibra de trigo, inulina, psyllium.

El análisis estadístico de los datos obtenidos para la humedad, no mostró diferencias significativas $(\mathrm{p} \leq 0,05)$ entre los quesos con y sin homogeneizado, con y sin sal, y con y sin fibra. El contenido de humedad promedio de los quesos elaborados fue de $70,9 \pm 0,5 \%$. Por lo tanto se los puede clasificar dentro de la categoría de quesos de pasta muy blanda que presentan un alto contenido de humedad (mayor al 55\%) según el Código Alimentario Argentino (CAA) debido a que no tienen etapa de maduración o es 
muy corta (Guinee y col., 1999) y que la etapa de desuerado se realiza sin la aplicación de presión.

Tabla 3.2 Composición centesimal, contenidos de Sodio y Calcio $[\mathrm{mg} / 100 \mathrm{~g}]$ y valor calórico [kcal/100g] de los quesos sin fibra elaborados con leche de oveja. HCS: Homogeneizado con sal; HSS: Homogeneizado sin sal; SHCS: Sin Homogeneizar con sal; SHSS: Sin homogeneizar sin sal.

\begin{tabular}{lcccc}
\hline & HCS & HSS & SHCS & SHSS \\
\hline Humedad & $71.2 \pm 0.7$ & $70.5 \pm 0.9$ & $70.8 \pm 0.8$ & $71.3 \pm 0.5$ \\
Cenizas & $1.1 \pm 0.1$ & $1.0 \pm 0.2$ & $1.2 \pm 0.2$ & $1.1 \pm 0.1$ \\
Lípidos & $13.1 \pm 0.3$ & $13.0 \pm 0.2$ & $12.9 \pm 0.1$ & $13.0 \pm 0.1$ \\
Proteínas & $11.8 \pm 0.8$ & $12.6 \pm 0.7$ & $12.1 \pm 0.6$ & $12.4 \pm 0.6$ \\
Hidratos de carbono & $2.0 \pm 0.2$ & $2.3 \pm 0.3$ & $2.0 \pm 0.1$ & $2.1 \pm 0.4$ \\
Sodio & $364 \pm 10$ & $155 \pm 12$ & $351 \pm 15$ & $150 \pm 10$ \\
Calcio & & & & \\
Valor calórico & $172.7 \pm 10$ & $177.5 \pm 8$ & $173.2 \pm 6$ & $174.6 \pm 7$ \\
\hline
\end{tabular}

Los valores de cenizas obtenidos no mostraron diferencias significativas entre los quesos con y sin homogeneizado, con y sin sal, y con y sin fibra $(\mathrm{p}>0,05)$. Además, estos valores no mostraron diferencias significativas con respecto al contenido de minerales en la leche de oveja, que es la materia prima, a pesar de que la fabricación de los quesos conlleva una concentración de proteínas y materia grasa de la leche, sugiriendo que una gran proporción de los minerales no pasaron al suero que se separa luego de la coagulación de la leche ya que, pueden quedar retenidos en la red proteica.

En cuanto al contenido de lípidos, el análisis estadístico tampoco reveló diferencias significativas $(\mathrm{p}>0,05)$ entre los quesos con y sin homogeneizado, con y sin sal, y con y sin fibra. Los quesos formulados presentaron un valor promedio de 13,0 \pm $0,1 \%$ de lípidos en su composición ( $44.6 \%$ de materia grasa del extracto seco). Los quesos obtenidos pueden considerarse dentro de la categoría de quesos semimagros según el CAA vigente, lo que es un hecho positivo desde el punto de vista de la 
aceptación por parte de los consumidores ya queactualmente, éstos tienen muy en cuenta la relación entre la alimentación y la salud, eligiendo cada día más productos saludables, por ejemplo los que en su rótulo se lee la frase: bajo contenido graso alguna otra palabra que indique el mismo concepto.

Tabla 3.3 Composición centesimal y valor calórico $[\mathrm{kcal} / 100 \mathrm{~g}]$ de los quesos con los diferentes tipos de fibras. QFB: Queso con fibra de bambú; QFT: Queso con fibra de trigo; QFI: Queso con inulina; QFP: Queso con psyllium.

\begin{tabular}{|c|c|c|c|c|}
\hline & QFB & QFT & QFI & QFP \\
\hline Humedad & $69.6 \pm 0.9$ & $69.5 \pm 0.9$ & $69.9 \pm 0.6$ & $70.5 \pm 0.5$ \\
\hline Cenizas & $1.00 \pm 0.17$ & $1.01 \pm 0.12$ & $1.02 \pm 0.17$ & $1.02 \pm 0.11$ \\
\hline Lípidos & $12.5 \pm 0.5$ & $12.4 \pm 0.3$ & $12.3 \pm 0.4$ & $12.0 \pm 0.5$ \\
\hline Proteínas & $11.6 \pm 0.7$ & $11.5 \pm 0.6$ & $11.5 \pm 0.8$ & $11.4 \pm 0.5$ \\
\hline $\begin{array}{l}\text { Hidratos de carbono } \\
\text { totales por diferencia }\end{array}$ & $5.3 \pm 0.9^{*}$ & $5.6 \pm 0.8^{*}$ & $5.3 \pm 0.8^{*}$ & $5.1 \pm 0.7^{*}$ \\
\hline $\begin{array}{l}\text { Glúcidos totales } \\
\text { reductores }\end{array}$ & $2.2^{\mathrm{b}} \pm 0.1$ & $2.2^{\mathrm{b}} \pm 0.1$ & $2.3^{b} \pm 0.3$ & $3.6^{\mathrm{a}} \pm 0.5$ \\
\hline Valor calórico & $173.2 \pm 6.2$ & $172.5 \pm 6.5$ & $170.8 \pm 8.3$ & $173.5 \pm 5.9$ \\
\hline
\end{tabular}

(* Fibra agregada: $3 \%)$

La cantidad de proteína obtenida en los quesos no exhibió diferencias significativas entre los quesos con y sin homogeneizado, con y sin sal, y con y sin fibra, obteniéndose un valor medio de $12,2 \pm 0,7 \%$ de proteína en los quesos. Los quesos de pasta muy blanda elaborados con leche de vaca, de marcas reconocidas (Sancor y La Serenísima) existentes en el mercado nacional, poseen en promedio un contenido proteico de 5,75 \% para la presentación clásica y de 9,35\% para la presentación "light". Teniendo en cuenta estos valores, los quesos desarrollados en este trabajo, presentaron un mayor contenido de proteínas que los productos comerciales, lo cual es muy destacable y coincide con el hecho de que el contenido proteico en la leche de oveja es superior al de la leche de vaca. Además, las micelas de caseínas de la leche de oveja poseen una estructura diferente en cuanto al diámetro, hidratación y mineralización, tienen más cantidad de calcio y fosforo inorgánico, con respecto a las que provienen de la leche de vaca. Esto hace que el tiempo y la velocidad de coagulación sea diferente y se obtengan geles menos firmes pero más fácilmente digeribles, con un contenido 
mayor de proteínas (Park y col., 2007, Balthazar y col., 2017). Además, la leche de oveja no posee aglutinina, lo que mejora la digestibilidad de los nutrientes en comparación con la leche de vaca que si la contiene (Park y col., 2007).

Los valores obtenidos para los hidratos de carbono no tuvieron diferencias significativas $(\mathrm{p}>0,05)$ entre los quesos con y sin homogeneizado y con y sin sal (Tabla 3.2). Hay que tener en cuenta que la lactosa es el hidrato de carbono principal de la leche y que los microorganismos empleados para acidificar y precipitar las caseínas consumen esta lactosa y producen principalmente ácido láctico, disminuyendo su contenido con respecto a la leche utilizada como materia prima. Los quesos frescos tienen un contenido de lactosa remanente debido a que se elaboran sin una etapa de maduración y las bacterias lácticas que se agregan como cultivo iniciador no terminan de consumir toda la lactosa presente (ver Tabla 1.1 del Capítulo Introducción). La lactosa es un nutriente valioso porque favorece la absorción intestinal de calcio, magnesio y fósforo y también favorece la utilización de vitamina C (Ramos y Juarez, 2011).

La adición de fibras de distinto origen causó diferencias significativas $(\mathrm{p} \leq 0.05)$ en el contenido de hidratos de carbono calculados por diferencia, entre los quesos con y sin fibras, debido a la presencia de las fibras. En el caso de los quesos con fibra, también se realizó el ensayo de la determinación de glúcidos totales reductores con el reactivo de Fehling, para valorar el contenido de lactosa en los quesos adicionados con fibras. Como puede observarse en la Tabla 3.3, no hubo diferencias significativas $(p>0,05)$ en los hidratos de carbono reductores, entre los quesos sin fibra y los adicionados con inulina, fibra de trigo o bambú, ya que éstas, no reaccionan con el reactivo de Fehling. No obstante, si hubo diferencias significativas en los hidratos de carbono reductores entre los quesos con psyllium y los quesos con las demás fibras, ya que el psyllium tiene en su formulación un $50 \%$ de sacarosa como excipiente.

\subsubsection{Determinación de Sodio}

El contenido medio de sodio fue de $357,5 \pm 9,2 \mathrm{mg} / 100 \mathrm{~g}$ para los quesos a los cuales se le adicionó un $0,3 \mathrm{~g}$ de sal cada $100 \mathrm{~g}$ de queso, y de $152,5 \pm 3,5 \mathrm{mg} / 100 \mathrm{~g}$ para los quesos sin sal agregada (Tabla 3.2). Los quesos untables del mercado presentan entre 120 y $360 \mathrm{mg} / 100 \mathrm{~g}$ de producto, siendo estos valores similares a los valores hallados para los quesos con y sin sal elaborados en este trabajo de tesis. 
Nutricionalmente esto es positivo, ya que en este trabajo de tesis se elaboraron productos más ricos en nutrientes como proteínas y lípidos de alta calidad nutricional, que los quesos del mismo tipo existente en el mercado, pero sin aumentar significativamente el aporte de sodio.

\subsubsection{Determinación de Calcio}

En relación al calcio, se mostraron diferencias significativas entre los quesos con y sin sal agregada luego de la etapa de desuerado durante la elaboración de queso (Tabla 3.2). El valor medio de calcio en los quesos con sal agregada fue de $392 \mathrm{mg} / 100 \mathrm{gr}$ de queso $\pm 11,3 \%$, mientras que en los quesos sin sal agregada el promedio fue de 269,5 $\mathrm{mg} / 100$ gr de queso $\pm 30,4 \%$. Esta diferencia puede deberse a que la adición de cloruro de sodio favorece las interacciones proteína-proteína. Por lo tanto, si las caseínas se encuentran más unidas, también se retiene a su vez, más calcio (Badui Dergal, 2006).

\subsubsection{Determinación de la composición de ácidos grasos}

El perfil de los ácidos grasos que contienen los quesos homogeneizados con sal y sin homogeneizar sin sal, se puede observar en la Tabla 3.4. En ambas formulaciones se pudo notar que el ácido graso más abundante es el ácido palmítico, el cual, representa entre el 23 y $26 \%$ del total, seguido por los ácidos oleico, mirístico, esteárico, cáprico y láurico. Estos seis ácidos más importantes reúnen más del $80 \%$ del total de ácidos grasos presentes en los quesos elaborados. La leche de oveja contiene más capróico (C6:0), caprílico $(\mathrm{C} 8: 0)$ y cáprico $(\mathrm{C} 10: 0)$ que la leche de vaca. Estos ácidos grasos están asociados con el sabor característico de los quesos y el estudio de sus proporciones presentes en los productos lácteos puede ser usado para detectar mezclas de leches de diferentes especies (Ramos y Juarez, 2011) para evaluar posibles adulteraciones, considerando que en la actualidad los productos lácteos de leches de cabra y oveja se comercializan con un valor superior a los elaborados con leche de vaca. Se ha observado que los ácidos grasos de cadena corta no tienen un efecto perjudicial sobre la colesterolemia e incluso algunos han demostrado un efecto beneficioso sobre el metabolismo del colesterol (Huth y col., 2012; Visioli y Strata, 2014, Olmedilla-Alonso 2017). También se ha notado que bajas concentraciones de ácido butírico contribuyen a 
la inhibición in vitro de las líneas celulares de cáncer humano y que los ácidos capróico, caprílico y cáprico podrían reducir el peso corporal y la grasa corporal (Rasmussen y col., 2010; Foglietta y col., 2014). En los quesos elaborados en este trabajo se ha encontrado un alto contenido de ácido oleico así como en quesos y yogures elaborados por otros investigadores con leche de vaca y oveja (Albenzio y col., 2013 y Balthazar y col., 2016). Se ha observado que un alto consumo de ácido oléico disminuye los niveles de colesterol LDL en sangre, mientras que el colesterol HDL no se modifica (Balthazar y col., 2017). El ácido esteárico por su conversión en ácido oleico -una vez absorbidono eleva la colesterolemia (WHO, 2003).

Así como en la leche de oveja y en los quesos de este mismo origen, se ha hallado en los quesos elaborados en este trabajo de tesis un contenido importante de ácido linoléico conjugado (CLA). El complejo CLA exhibe una interesante actividad fisiológica ya que tiene efecto antiobesidad, anticarcinogénico, antidiabetes, antioxidante e inmunoregulatorios (Wang y Lee, 2015, Olmedilla-Alonso 2017). Asimismo, se han hallado ácidos grasos trans como el ácido trans-9-Elaídico (C18:1T), el ácido linoelaídico (C18:2T) y el ácido trans, trans 10-13 nonadecadienoico de mayor a menor proporción. En la leche el contenido de ácidos grasos monoinsaturados varía entre 2,5 a $5 \%$ del total de los ácidos grasos, dependiendo de la especie productora de leche y de la estación del año. En general la leche de oveja contiene las mayores cantidades, seguida por la leche de vaca y la leche de cabra (Ramos, 2011). Si bien, se ha documentado en décadas pasadas, un aumento en el riesgo de padecer enfermedades cardiovasculares debido al consumo de ácidos grasos trans industriales provenientes del proceso de hidrogenación parcial de aceites vegetales, en los últimos años se han llevado a cabo los mismos estudios con alimentos ricos en ácidos grasos trans naturales y se ha observado que no elevan el riesgo de desarrollar enfermedades cardiovasculares cuando el consumo de ácidos grasos trans naturales es moderado, dentro de una dieta equilibrada (Tardy y col., 2011).

Los perfiles de ácidos grasos obtenidos para las formulaciones de quesos concuerdan con los informados por Park y col. (2007), Albenzio y col. (2013 y 2016) y Balthazar y col. (2017) para la leche de oveja y quesos de leche de oveja. Además, se detectaron en pequeñas cantidades, otros ácidos grasos con estructura de mayor cantidad de carbonos como los ácidos paullínico, heneicosanóico, behénico, dihomo- $\gamma$-linolénico, araquidónico, tricosílico, tretracosanóico, eicosapentaenóico, docosahexanóico, estos dos últimos de gran importancia nutricional ya que son ácidos grasos omega-3. 
Tabla 3.4- Composición de ácidos grasos [\% del total de ácidos] para los quesos homogeneizados con sal y sin homogeneizar sin sal.

\begin{tabular}{|c|c|c|c|}
\hline Nomenclatura química & Nombre del ácido graso & HCS & SHSS \\
\hline C4:0 & Butírico & $2,1 \pm 0,1$ & $2,0 \pm 0,1$ \\
\hline C6:0 & Capróico & $1.1 \pm 0,01$ & $1,2 \pm 0,01$ \\
\hline C8:0 & Caprílico & $2,5 \pm 0,1$ & $2,5 \pm 0,1$ \\
\hline C10:0 & Cáprico & $8.3 \pm 0,2$ & $8.2 \pm 0,5$ \\
\hline C11:0 & Undecanóico & $0,2^{\mathrm{a}} \pm 0,02$ & $0,1^{\mathrm{b}} \pm 0,01$ \\
\hline C12:0 & Láurico & $6.6^{\mathrm{a}} \pm 0,3$ & $5,9^{\mathrm{b}} \pm 0,2$ \\
\hline C13:0 & Tridecanóico & $0,2 \pm 0,03$ & $0,2 \pm 0,02$ \\
\hline C14:0 & Mirístico & $11.7 \pm 0,2$ & $11,8 \pm 0,2$ \\
\hline C14:1 & Miristoléico & $0,2 \pm 0,02$ & $0,2 \pm 0,04$ \\
\hline C15:0 & Pentadecanóico & $1,3 \pm 0,1$ & $1,4 \pm 0,1$ \\
\hline C15:1 & cis-10-Pentadecanóico & $0,2 \pm 0,02$ & $0,3 \pm 0,03$ \\
\hline C16:0 & Palmítico & $23,5^{b} \pm 0,2$ & $24,7^{a} \pm 0,9$ \\
\hline C16:1 & Palmitoléico & $0,9 \pm 0,04$ & $1,1 \pm 0,08$ \\
\hline C17:0 & Margárico & $0,8^{\mathrm{b}} \pm 0,03$ & $1,0^{\mathrm{a}} \pm 0,04$ \\
\hline C17:1 & cis-10-Heptadecanóico & $0,2 \pm 0,04$ & $0,4 \pm 0,05$ \\
\hline C18:0 & Esteárico & $10,5^{b} \pm 0,1$ & $12,4^{\mathrm{a}} \pm 0,3$ \\
\hline C18:1T & trans-9-Elaídico & $1,8^{\mathrm{b}} \pm 0,01$ & $2,2^{\mathrm{a}} \pm 0,02$ \\
\hline C18:1 & Oleíco & $21.9^{b} \pm 0,1$ & $23,0^{\mathrm{a}} \pm 0,1$ \\
\hline C18:2 & Linoléico & nd & $1,7 \pm 0,08$ \\
\hline C18:2T & Linoelaídico & nd & $0,1 \pm 0,04$ \\
\hline CLA & Linoléico conjugado* & $1.1^{\mathrm{b}} \pm 0.08$ & $1.4^{\mathrm{a}} \pm 0.05$ \\
\hline C18:3 ALFA & $\alpha$-Linolénico & nd & $0,5 \pm 0,07$ \\
\hline C18:3 GAMA & $\gamma$-Linolénico & $0,8 \pm 0,04$ & $0,5 \pm 0,1$ \\
\hline C19:2T & $\begin{array}{l}\text { trans, trans, } 10-13 \\
\text { Nonadecadienoico }\end{array}$ & $0,3 \pm 0,08$ & nd \\
\hline C19:2 & 10-13 Nonadecadienoico & $2,0 \pm 0,03$ & nd \\
\hline C20:0 & Araquídico & $0,3 \pm 0,02$ & $0,4 \pm 0,04$ \\
\hline C20:1 & Paullínico & $0,05 \pm 0,003$ & $0,1 \pm 0,05$ \\
\hline C21:0 & Heneicosanóico & $0,8 \pm 0,05$ & $0,5 \pm 0,07$ \\
\hline C22:0 & Behénico & $0,1 \pm 0,02$ & $0,2 \pm 0,07$ \\
\hline C20:2 & 11-14 Eicosadienoico & $0,1 \pm 0,02$ & $0,1 \pm 0,03$ \\
\hline C20:3 & dihomo- $\gamma$-Linolénico & nd & $0,1 \pm 0,05$ \\
\hline C20:4 & Araquidónico & nd & $0,1 \pm 0,04$ \\
\hline C23:0 & Tricosílico & $0,1 \pm 0,04$ & $0,1 \pm 0,03$ \\
\hline C22:2 & 13-16 Docosadienoico & $0,1 \pm 0,03$ & $0,1 \pm 0,04$ \\
\hline C24:0 & Tretracosanóico & nd & $0,1 \pm 0,05$ \\
\hline C20:5 & Eicosapentaenóico & $0,1^{\mathrm{a}} \pm 0,02$ & $0,04^{b} \pm 0,002$ \\
\hline \multirow[t]{7}{*}{ C22:6 } & Docosahexanóico & $0,2 \pm 0,01$ & $0,1 \pm 0,02$ \\
\hline & Saturados & $70.1 \pm 1.1$ & $72.7 \pm 1.5$ \\
\hline & Monoinsaturados & $25.3 \pm 0.9$ & $27.3 \pm 1.1$ \\
\hline & Poliinsaturados & $4.7 \pm 0.1$ & $4.7 \pm 0.08$ \\
\hline & Total insaturados & $\mathbf{3 0 . 0} \pm \mathbf{0 . 8}$ & $32.0 \pm 1.0$ \\
\hline & Insaturados/Saturados & $0.4 \pm 0.04$ & $0.4 \pm 0.05$ \\
\hline & $n-6 / n-3$ & $2.7^{b} \pm 0.1$ & $3.78^{a} \pm 0.1$ \\
\hline
\end{tabular}

Letras diferentes en cada fila indican que los promedios difieren significativamente $(\mathrm{p}<0,05)$. nd: no detectado. *todos los isómeros. 
E1 Instituto Nacional de Salud de Estados Unidos recomienda el consumo del ácido eicosapentaenóico para elevar la calidad de vida y mejorar el tratamiento de enfermedades como dislipemias, obesidad, diabetes mellitus y enfermedades cardiovasculares (Bays y col., 2016). A su vez, el ácido docosahexanóico está recomendado para prevenir el deterioro de la capacidad cognitiva en adultos mayores (Cederholm y col. 2013).

Desde el punto de vista nutricional y de la salud es muy relevante analizar el perfil de los ácidos grasos de un alimento teniendo en cuenta diferentes relaciones como insaturados/saturados y n-6/n-3 que permite a los especialistas conectarlos con el riesgo de padecer enfermedades cardiovasculares y otras no transmisibles, como sobrepeso y diabetes. La relación insaturados/saturados debería hallarse entre 0,4 - 1 y la relación n6/n-3 no debería exceder de 4 para disminuir el riesgo de contraer enfermedades no transmisibles (Jiménez-Colmenero, 2007; Gómez Candela y col., 2011; Simat y col. 2015). Los quesos funcionales elaborados en este trabajo de tesis están dentro de estos parámetros saludables.

El análisis estadístico realizado puso en evidencia que hubo diferencias significativas $(p<0,05)$ en el porcentaje de algunos de los ácidos grasos que conforman el perfil de los quesos homogeneizados y adicionados con sal con respecto a los quesos sin homogeneizar y sin sal (Tabla 3.4). Teniendo en cuenta que el homogeneizado y la adición de sal se realizaron después del cuajado de la leche y desuerado, las diferencias en los perfiles, pueden haber surgido debido a la homogeneización, la adición de sal y los tiempos de espera entre la elaboración de los quesos y el análisis de las muestras. En estas etapas se puede haber producido algún tipo de degradación de los ácidos grasos, ya que la homogeneización disminuye el tamaño de los glóbulos de grasa por rotura y nueva formación de los mismos según López (2005), Lopez y col. (2007) y Ong y col. (2010) como se comentará más adelante, en la sección de la microestructura de los quesos elaborados.

\subsubsection{Determinación del valor calórico}

Se calcularon los valores calóricos de los quesos desarrollados que se presentan en las Tablas 3.2 y 3.3. De acuerdo al análisis estadístico realizado, no hubo diferencias significativas entre los quesos con y sin homogeneizado, y con y sin sal, y con y sin fibra. Según el CAA, en el artículo 1385, se le asigna a la fibra dietaria un valor calórico 
de $0 \mathrm{Kcal} / \mathrm{g}$, sin embargo, los valores calóricos aceptados legalmente, para el etiquetado nutricional de fibra dietética pueden ser diferentes según el país o región donde se haya registrado el producto. Según Tungland y Meyer (2002), los ácidos grasos de cadena corta que resultan del proceso de fermentación de la fibra en el intestino grueso proporcionan una cierta cantidad de energía debido a su metabolismo en el hígado. Por lo tanto, el valor energético de las fibras está condicionado al grado de fermentación en el colon y a su metabolismo en el hígado. Las fracciones de fibra que no se fermentan, tienen un contenido calórico cercano a $0 \mathrm{Kcal} / \mathrm{g}$, mientras que los datos de estudios calóricos indican que el rendimiento energético promedio de la fermentación de fibra en especies monogástricas está en el rango de 1.5 a $2.5 \mathrm{Kcal} / \mathrm{g}$. Un estudio reciente (Menezes y col., 2016) recomienda utilizar el valor de 1,9 Kcal / g de fibra dietética en el cálculo del valor total de energía de los alimentos. Teniendo en cuenta este trabajo, puede considerarse que los quesos con fibras de bambú y trigo tienen el valor calórico presentado en la Tabla 3.3. En cambio los quesos con inulina y con psyllium pueden generar $170,8 \pm 8,3$ y $173,5 \pm 5,9 \mathrm{Kcal} / 100$ gr de queso, respectivamente.

\subsubsection{Microestructura y pH de los quesos elaborados}

Teniendo en cuenta el proceso de elaboración utilizado, los quesos obtenidos tienen una consistencia semisólida. La etapa más importante que genera esta consistencia es la gelificación de la leche, debido a que la etapa de desuerado es corta y sin presión y no hay etapa de maduración, en comparación con otros tipos de quesos. La gelificación se produce tanto por la acidificación como por la utilización de cuajo. Por lo tanto, es un gel generado por la combinación de dos procesos: acidificación por fermentación y ruptura enzimática. Luego de la pasteurización de la leche, esta se enfría a $30{ }^{\circ} \mathrm{C}$, se adicionan los fermentos mesófilos y se espera $2 \mathrm{~h}$ para que los microorganismos superen la fase Lag de crecimiento. A las $2 \mathrm{~h}$ el $\mathrm{pH}$ de la leche promedio fue de $6,40 \pm 0,02$. Luego, se baja nuevamente la temperatura a $20{ }^{\circ} \mathrm{C}$ (temperatura preestablecida de almacenamiento para producir la gelificación) y se agrega una pequeña cantidad predeterminada de cuajo para que se produzca la coagulación enzimática en un lapso de tiempo largo (16-18 h).

En este tiempo los microorganismos crecen, consumen la lactosa de la leche, producen ácido láctico y van disminuyendo el $\mathrm{pH}$. Según la curva de acidificación para los microorganismos empleados a $22{ }^{\circ} \mathrm{C}$ (Figura 3.2), provista por Christian Hansen A/S 
(Holanda), el pH llega aproximadamente a 4,6 entre 14-15 h. Simultáneamente, por la acción enzimática del cuajo, una pequeña proporción de micelas de caseína se van escindiendo continuamente, en la posición de Phe105 y Met106 de la fracción $\kappa$ caseína. Según Dalgleish (1979), la coagulación enzimática no ocurre hasta que más del $85 \%$ de la caseína se hidroliza. En este trabajo de tesis se ha observado que alrededor de las 16-18 h la formación del gel se completó, obteniendo la cuajada. Luego, se liró el cuajo en cruz y se dejó desuerar durante $3 \mathrm{~h}$ a $20{ }^{\circ} \mathrm{C}$, logrando el producto final con un valor de $\mathrm{pH}$ de $4,58 \pm 0,05$ y humedad de $70 \pm 0,8 \%$.

Considerando el proceso de manufactura utilizado en la elaboración de los quesos, la cuajada o el gel obtenido se denomina mixto o combinado. Este gel producido es predominantemente ácido pero sin embargo, sus características son modificadas en cierto grado por el cuajo adicionado (Castillo y col., 2006a). Es decir, que en el proceso de elaboración predomina la acidificación por fermentación, frente a la acción de la hidrólisis enzimática por el cuajo, si bien ambos procesos ocurren simultáneamente, con diferentes mecanismos de desestabilización de las micelas de caseína (Schulz-Collins y Senge, 2004; Salvatore y col., 2011). Ambos procesos, reducen la estabilidad estérica y electrostática de la micela de caseína mediante la eliminación o neutralización de carga de la capa de polielectrolito de la $\kappa$-caseína que existe en la superficie de las micelas de caseína, aunque a través de diferentes mecanismos. En la acidificación por fermentación, se neutralizan las cargas negativas de la superficie de la micela, reduciendo la repulsión electrostática y provocando que la capa de polielectrolito colapse sobre la micela, eliminando posteriormente la repulsión estérica y produciendo la agregación de las micelas a pH 4.9. En la coagulación por el cuajo, la estabilidad de las micelas se reduce mediante la hidrólisis enzimática que libera la porción hidrófila glicosilada llamada caseinomacropéptido (CMP) en el suero, dejando una región hidrófoba en la superficie de la micela. La liberación del 85-90\% del CMP reduce significativamente la repulsión estérica y las micelas de caseína pierden su estabilidad quedando expuestas al medio ambiente las fracciones $\alpha_{\mathrm{s}} \mathrm{y} \beta$-caseínas. Los restos de fosfoserina presentes en estas fracciones se unen al calcio presente en la fase acuosa mediante enlaces cruzados, formando de este modo un complejo rígido, insoluble en agua, de fosfato-calcio-paracaseinato conocido como cuajada (Holt, 1992; Li y Dalgleish, 2006; Cooper y col., 2010). Es decir que una vez desestabilizadas las caseínas, comienzan a agregarse y finalmente forman una red tridimensional que atrapa el suero y los glóbulos de grasa (Mezzenga y col., 2005). El tratamiento térmico que se 
le efectúa a la leche antes de la formación del gel también afecta a los dos procesos de desestabilización de diferente manera. Se pueden formar complejos solubles de proteínas del suero de la leche inducidos por el calor, que se pueden asociar con las micelas tras la acidificación, y esta interacción puede resultar en la formación de un gel a un $\mathrm{pH}$ más alto, aumentando su rigidez y reduciendo la sinéresis. Además, los complejos solubles de proteínas del suero son capaces de ser hidrolizados por el cuajo y también se asocian con las micelas de caseína (Cooper y col., 2010). Por todo esto, los factores más importantes en la formación de la micro y macro estructura de la cuajada son el contenido de caseína y calcio de la leche y el pH final de la cuajada.

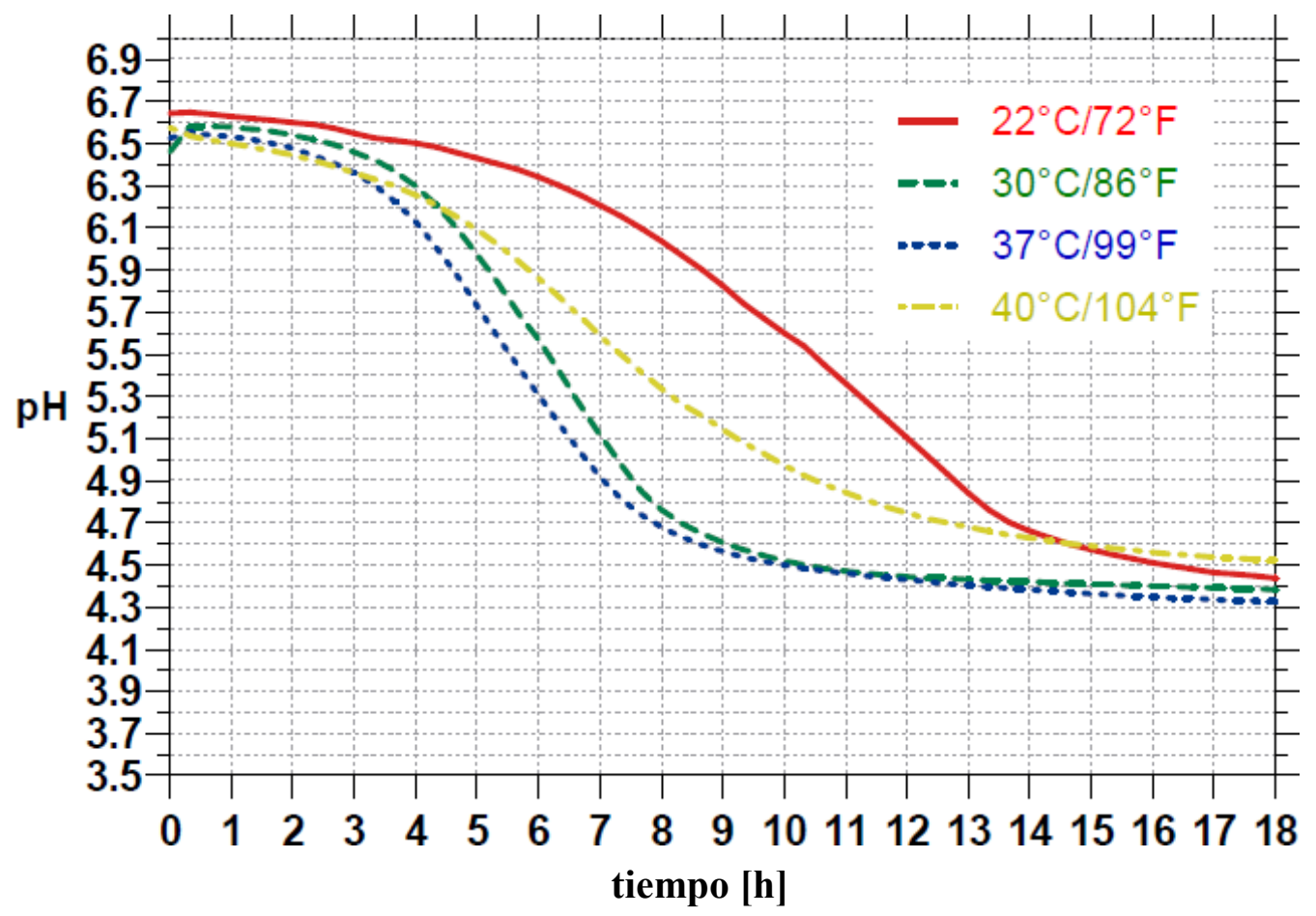

Figura 3.2 Curva de acidificación proporcionada por el proveedor (C. Hansen) en las especificaciones de los fermentos utilizados para elaborar los quesos en este trabajo de tesis.

Las imágenes obtenidas por microscopía láser confocal de las muestras de quesos con y sin homogeneizar, con y sin sal y con y sin fibra en este trabajo de tesis concuerdan, con el esquema de la Figura 3.3 y con las características de un gel ácido como lo describe Horne (1999) quien realizó una revisión sobre la formación y estructura de geles lácteos obtenidos por acidificación. En todas las micrografías obtenidas, se pudo observar la matriz proteica como una red de partículas gruesas unidas en grupos, cadenas y cordones, teñida de verde contra un fondo oscuro. También se visualizaron los glóbulos de grasa (teñidos de rojo) ubicados en los poros de la red de caseína. Estos son de menor tamaño de lo que aparecen en el esquema de la Figura 3.3, 
ya que el tamaño medio de los glóbulos de grasa de la leche de oveja es de 3,3 $\mu$ m (Park y col., 2007). Además, se puedieron ver en la red poros pequeños en negro, que estaban ocupados por la fase acuosa (suero). En los quesos a los cuales se ha añadido fibra dietaria, se observaron las partículas de fibra como estructuras no teñidas. Su visualización se favoreció comparando con las micrografías de las partículas de fibras del polvo comercial obtenidas por microscopía electrónica ambiental que acompañan a las imágenes de los quesos con fibras en todas las figuras presentadas. No se observaron diferencias microestructurales entre los quesos con y sin sal.

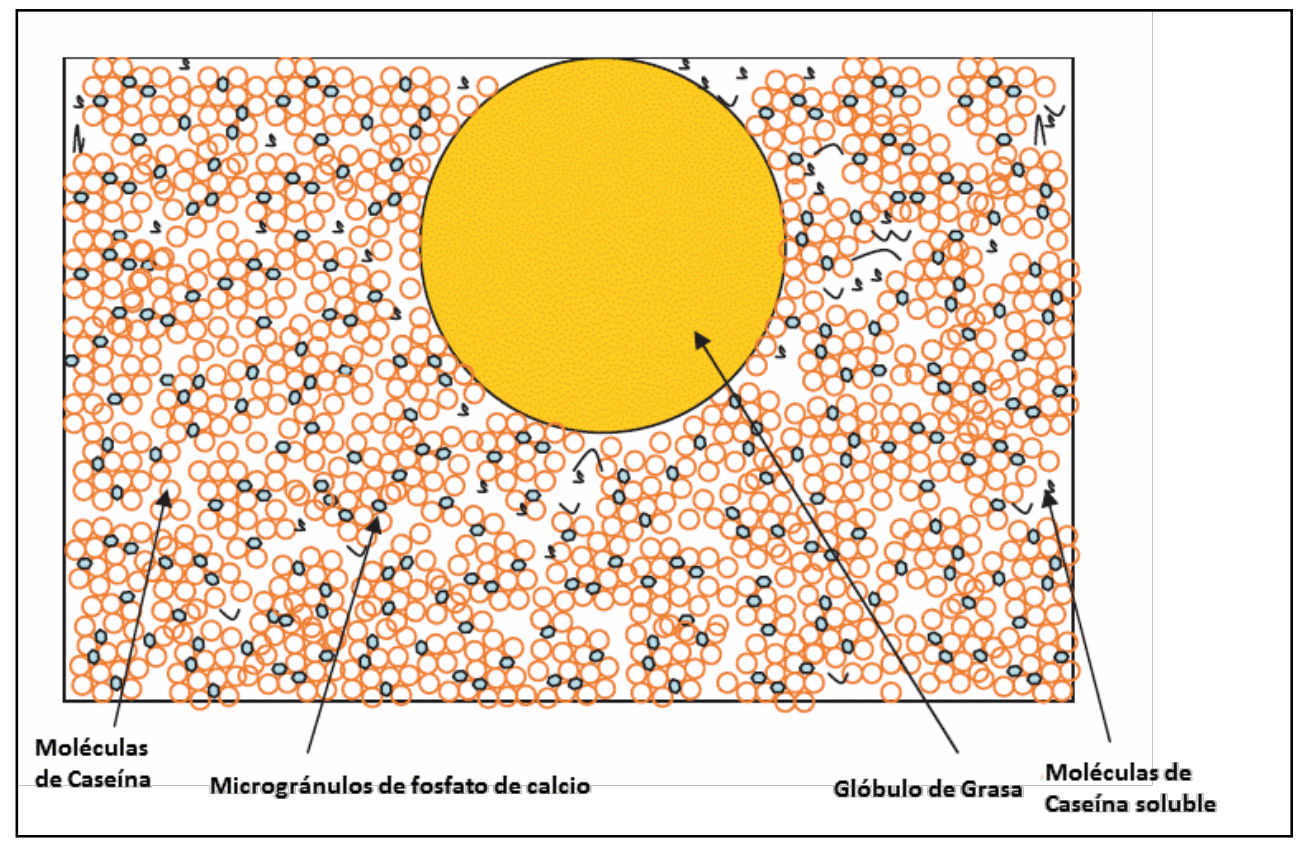

Figura 3.3 Microestructura esquemática de queso (Shimp, 1985)

Desde el punto de vista de las proteínas, las características de la red proteica observada en los quesos sin fibra de este trabajo de tesis (Figura 3.4) concordaron con el trabajo de Cooper y col. (2010) que estudiaron las características de los geles obtenidos por combinación de acidificación y cuajado a dos concentraciones con siete tratamientos térmicos de la leche previos a la gelificación. Ellos encontraron que la mejor red proteica (más interconectada y ramificada) se formaba con la menor concentración de cuajo y con el tratamiento térmico previo de la leche de mayor temperatura y tiempo. De igual manera, las propiedades de la red proteica de los quesos producidos en este trabajo de tesis, concordaron con la microestructura de quesos elaborados con una etapa de desuerado a $22^{\circ} \mathrm{C}$, presentados en el trabajo de Castillo y col. (2006b) quienes estudiaron el efecto de la temperatura y la concentración del inóculo en la microestructura, permeabilidad y sinéresis de los geles. 

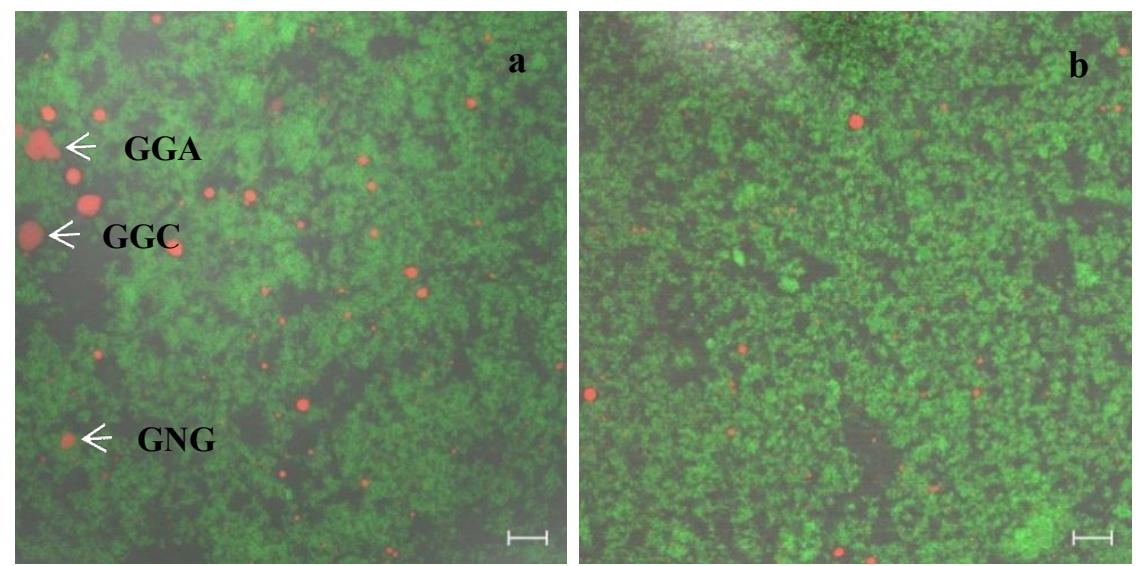

Figura 3.4 Fotomicrografías de queso sin fibra. a- Sin Homogeneizar y b- Homogeneizado. Las barras de escala corresponden a $10 \mu \mathrm{m}$. GGA: glóbulos de grasa agregados; GGC: glóbulo de grasa coalescido; GNG: grasa no globular

Además, se conoce que un aumento en la concentración de proteínas también mejora la red. La leche de oveja tiene un mayor contenido de proteínas que la leche de vaca, produciendo quesos con similar microestructura a los obtenidos por Salvatore y col. (2011), con leche de vaca ultrafiltrada que tiene mayor contenido de proteínas por este proceso. En las imágenes de los quesos homogeneizados (Figura 3.4b), pudo observarse que la red de proteínas se visualiza más particulada que en los quesos sin homogeneizar (Figura 3.4a) en los cuales pareciera estar más aglomerada en cúmulos.

Siguiendo con el análisis de los componentes de la leche, la fase grasa en la leche cruda de cualquier especie, se presentó en pequeñas gotas llamadas glóbulos de grasa nativos, cuyo tamaño varía desde 0.2 a $20 \mu \mathrm{m}$, con un diámetro volumétrico promedio de alrededor de $4 \mu \mathrm{m}$ (Mulder y Walstra, 1974) que depende del origen de la leche (Park y col., 2007, Balthazar, 2017). El corazón de estos glóbulos está compuesto principalmente de $98 \%$ de triacilgliceroles, de los cuales, al menos 200 han sido identificados (Gresti y col., 1993). Las moléculas de triacilgliceroles son altamente hidrofóbicas y están constituidas por una variedad de ácidos grasos (Jensen y Newburg, 1995). La diversidad de los triacilgliceroles y su polimorfismo es responsable de las complejas propiedades de cristalización y fusión, lo que provoca que la leche presente un amplio rango de temperatura de fusión entre - 40 a $40{ }^{\circ} \mathrm{C}$ (Lopez y col., 2007). Además, los glóbulos de grasa en la leche sin procesar, presentan una superficie cubierta por una membrana compuesta de fosfolípidos, colesterol, proteínas, glicoproteínas y otros componentes menores. Esta membrana está estructurada de la siguiente manera: una monocapa fosfolipídica interna contigua al corazón de materia 
grasa y una bicapa fosfolipídica más externa que tiene contacto con la fase acuosa de la leche (Lopez, 2005). Esta estructura que previene la coalescencia o fusión de los glóbulos a temperatura ambiente se puede alterar por fuerzas mecánicas, cambios de temperatura y $\mathrm{pH}$, empleados en el procesamiento de la leche cruda y en la fabricación de los quesos, pudiendo provocar la agregación y/o un aumento de tamaño de los mismos, así como también su ruptura y formación de cúmulos de lípidos no globulares (Bunner, 1965; Loewenstein y Gould, 1954; Lopez, 2005). Según Shimp (1985), una proporción de los glóbulos de grasa de la leche, dejan de formar parte de la emulsión, y ocupan en el queso los intersticios de la red del complejo de fosfato-calcioparacaseinato insoluble en agua y otra parte de los glóbulos se pierden en el desuerado. Esta disposición puede apreciarse en el esquema de la Figura 3.3. Además, estos huecos de la red de caseína también están ocupados por suero y como la mayoría de los glóbulos de grasa tienen un tamaño menor que los poros de la red, estos actúan como relleno interno de la red. A su vez, los glóbulos de grasa tienen una alta capacidad de retención de agua que favorecen la retención de suero en pequeños paquetes alrededor de los glóbulos de grasa, contribuyendo a la estructura del gel (Lopez y col., 2007; Ong y col., 2010).

En los quesos no homogeneizados elaborados, se han distinguido, además de los típicos glóbulos de grasa dentro de la red, agregados de los mismos, glóbulos de grasa coalescidos y grasa libre no globular (Figura 3.4a). Tanto la agregación y la coalescencia de los glóbulos pueden aparecer debido a la pasteurización y la coagulación de la leche durante el proceso de elaboración de los quesos (Lopez, 2005). Durante la etapa de desuerado, la cuajada del queso está sujeta a una presión ligera, ya que se suspende en el aire dentro de bolsas de tela permeable a $10{ }^{\circ} \mathrm{C}$ durante $4 \mathrm{~h}$ para separar la mayor parte del suero, pudiendo provocar además de la agregación y el aumento de tamaño de los glóbulos de grasa, la formación de grasa libre no globular. Esto puede explicarse teniendo en cuenta que la materia grasa de la leche está parcialmente solidificada a temperaturas entre 5 y $25^{\circ} \mathrm{C}$ y su consistencia está causada por la presencia una red de cristales de materia grasa en grasa líquida (Van Aken y Visser, 2000). Estos cristales de materia grasa sometidos a una cierta presión, pueden provocar un daño en la membrana de los glóbulos de grasa por sobresalir a través de ella destruyéndola y cambiando la disposición de la materia grasa a formas no esféricas (Lopez y col., 2007). El tamaño medio de los glóbulos de grasa en los quesos sin homogeneizar está dentro del rango de los hallados en la leche de oveja sin procesar. 
En todos los campos microscópicos observados de los quesos homogeneizados (Figura 3.4b), se puede observar que los glóbulos de grasa tienen un tamaño menor que los hallados en los quesos no homogeneizados. Este efecto también fue advertido por Ong y col. (2010) que estudiaron la microestructura de geles lácteos y cuajada de queso. Asimismo, un estudio de la microestructura de los glóbulos de grasa en productos lácteos llevado a cabo por Lopez (2005), reveló que el proceso de homogenización además de disminuir el tamaño, cambia la estructura de la membrana que rodea los glóbulos de grasa. Ésta, pasa a estar constituida por restos de la membrana nativa, seguida de secciones en las cuales se encuentran caseínas en forma de micelas o subunidades aisladas y secciones en las cuales se hallan proteínas del suero, principalmente $\beta$-lactoglobulinas. Esta adsorción de nuevos componentes en la membrana es la respuesta al aumento del área interfacial de la materia grasa en solución, como consecuencia del aumento del número de glóbulos que también provoca la homogeneización (Lopez y col., 2007). Según Ong y col. (2010), este cambio en la membrana de los glóbulos de grasa, favorece su interrelación con la red, apareciendo éstos como incrustados en la red del gel, lo que se puede observar en la Figura 3.4b.

Cuando se adiciona fibra dietaria a un alimento hay que tener en cuenta su distribución de tamaño de partículas y sus propiedades fisicoquímicas que son consecuencia de su composición química ya que, todas estas características, van a determinar cómo interactuen con el gel del queso ya formado. La Figura 3.5 muestra la distribución del tamaño de partículas de los polvos de las distintas fibras dietarias utilizados para adicionar a los quesos. En ella, se puede observar que todos los polvos de las fibras presentan una distribución monomodal. Para este tipo de distribución las medianas de los diámetros y el índice de dispersión son los parámetros más descriptivos que permiten analizar los resultados (ISO 13320:2009). Las medianas en orden ascendente son: $30,91 \mu \mathrm{m}$ para fibra de bambú, 55,64 $\mu \mathrm{m}$ para fibra de trigo, 64,33 $\mu \mathrm{m}$ para inulina y 391,79 $\mu \mathrm{m}$ para Psyllium. Los índices de dispersión de cada distribución, en orden ascendente son: 1,32 para el Psyllium, 1,65 para la fibra de bambú, 1,71 para la inulina, y 2,27 para la fibra de trigo. La fibra de bambú tiene el menor tamaño de partícula y una dispersión aceptable. El Psyllium tiene el mayor tamaño de partícula con una baja dispersión y la fibra de trigo tiene un tamaño medio de partícula con la mayor dispersión. 


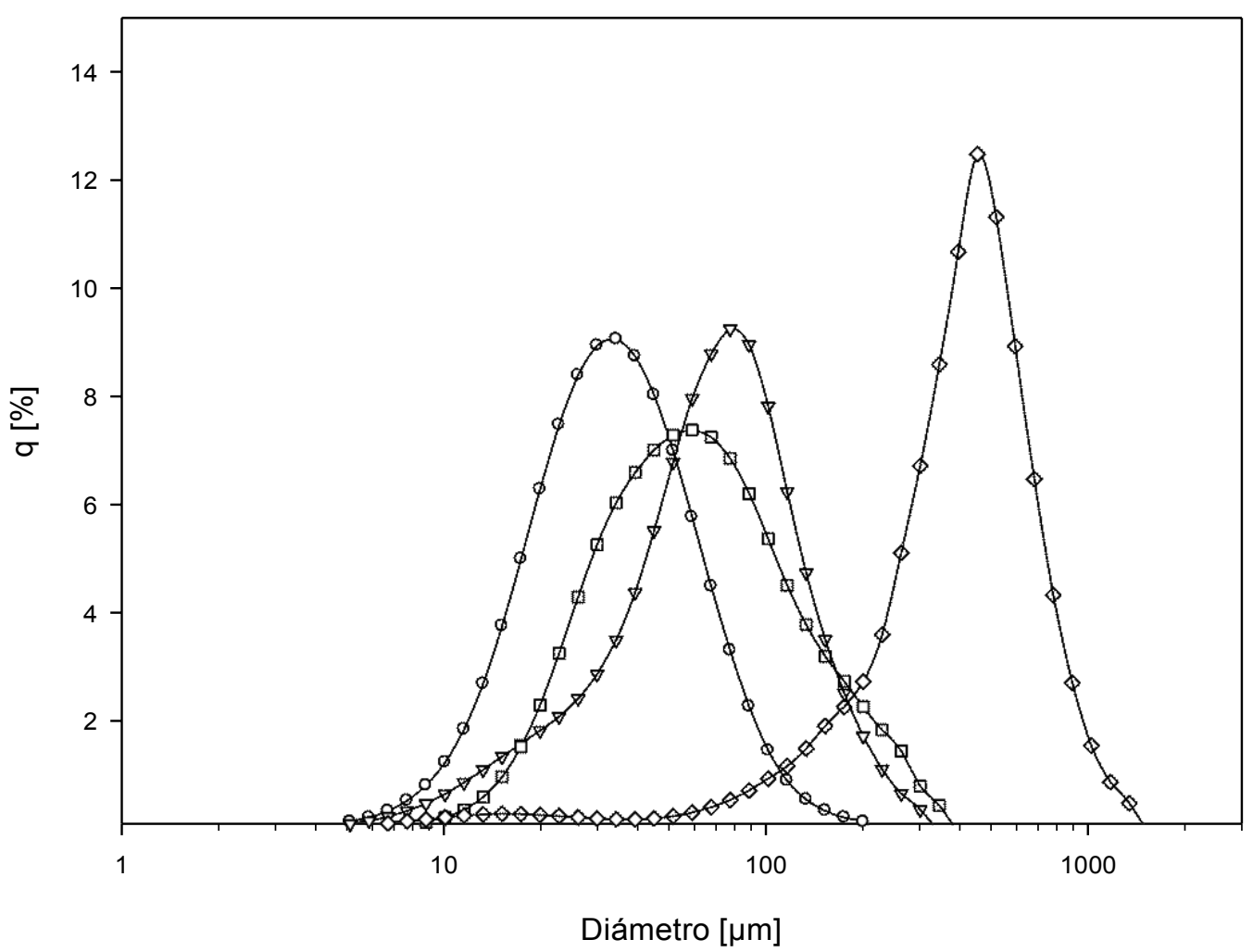

Figura 3.5 Distribución de tamaño de partículas para los polvos de fibras graficados como diámetro de una esfera $[\mu \mathrm{m}]$ con el mismo volumen que la partícula vs la fracción en volumen de cada diámetro. $-\bigcirc$ - fibra de bambú, $-\square$ - fibra de trigo, $\nabla$ - inulina, $-\nabla-P$ syllium

El tamaño de partícula influye en las propiedades de hidratación y en la capacidad de unión de lípidos de la fibra dietaria (Raghavendra et al. 2006) y por lo tanto, puede afectar la microestructura, la textura y el aspecto de los alimentos que las contengan (Aufret y col. 1994; Sendra y col., 2010). En la preparación de los quesos de este trabajo de tesis, las fibras se adicionan luego de la formación de la red proteica de caseína y del desuerado. En estas condiciones, las fibras en primer lugar van a hidratarse con el suero remanente del desuerado. Luego, dependiendo de sus características fisicoquímicas las fibras van a solubilizarse o no. Las fibras de trigo y bambú son insolubles, por lo tanto, es muy probable que puedan conservar sus tamaños de partículas en el producto final. Las Figuras 3.6 y 3.7 corresponden a quesos con fibra de bambú y de trigo, respectivamente. En ambas figuras, las partículas de las fibras aparecen contiguas a la red de proteína. En el caso de los quesos con fibra de trigo las partículas observadas son de tamaño muy diferente debido a la gran dispersión de tamaño que tiene este polvo. La microestructura de los quesos con inulina se puede visualizar en la Figura 3.8. 
Debido a su solubilidad (12\% p/v a $25{ }^{\circ} \mathrm{C}$, según Franck, 2002) que se puede observar en la Figura 3.8c, sus partículas no se visualizan en las fotomicrografías de los quesos. Las fotomicrografías de los quesos con psyllium se pueden ver en la Figura 3.9. La fibra presente en la semilla de Plantago ovata y en el preparado psyllium utilizado en este trabajo de tesis, contiene tanto fracciones solubles como insolubles. A concentraciones inferiores a $1 \% \mathrm{p} / \mathrm{v}$ esta fibra forma dispersiones viscosas mientras que a concentraciones de $2 \% \mathrm{p} / \mathrm{v}$, forma una masa gelatinosa (Chan y Wypyszyk, 1988). Por lo tanto, en el caso de estos quesos, el psyllium estaría formando una masa gelatinosa junto con la red proteica. Debido a que el tamaño de partículas de esta fibra es considerable pero parcialmente soluble en agua, posiblemente solo visualizamos la parte insoluble de la misma en las imágenes captadas por el equipo. De este modo, se puede observar la partícula de fibra en el fondo de la fotomicrografía, con la red de proteína por delante de la fibra (Figuras 3.8 a, b y d).

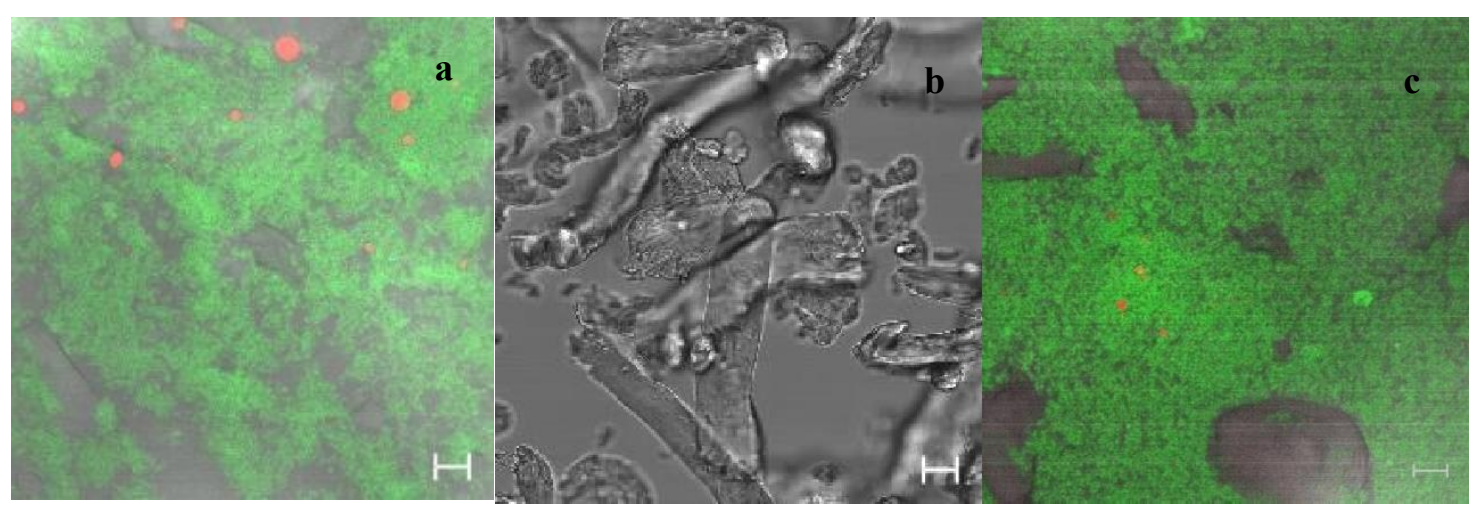

Figura 3.6 a- Fotomicrografía de queso con fibra de bambú sin homogeneizar, b- Fibra de bambú observada por microscopía óptica sin fluorescencia $65 \mathrm{x}$ c- Fotomicrografía de fibra de bambú homogeneizado. En todas las imágenes las barras de escala corresponden a $10 \mu \mathrm{m}$.

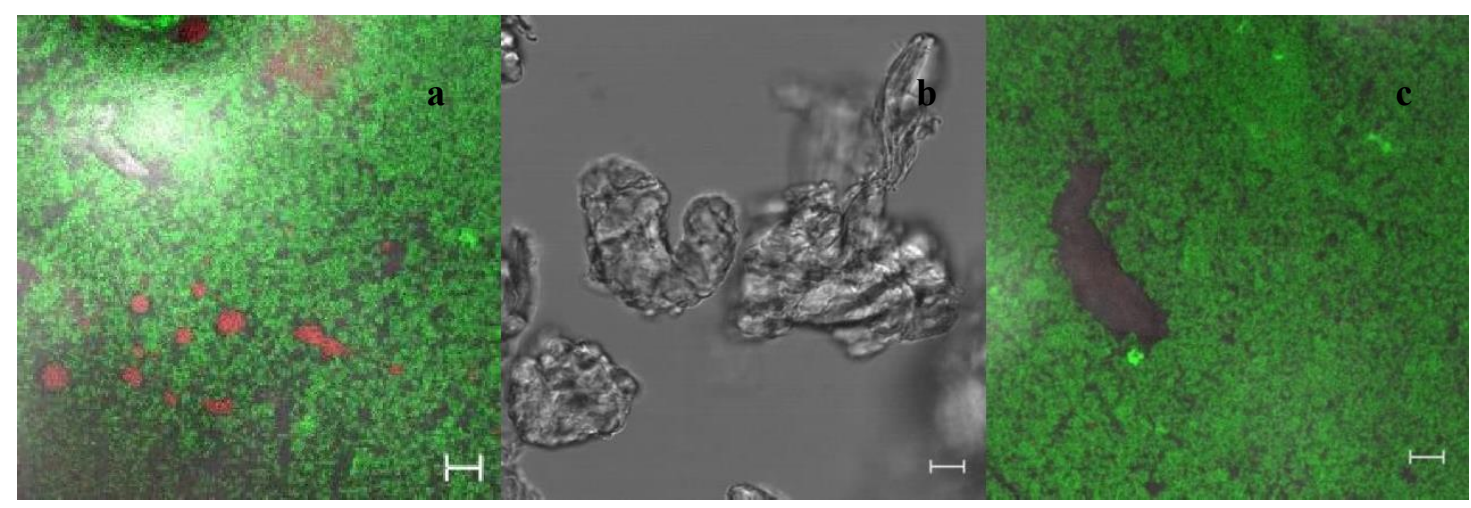

Figura 3.7 a- Fotomicrografía queso con fibra de trigo sin homogeneizar, b- Fibra de trigo observada por microscopía óptica sin fluorescencia $65 \mathrm{x}$ c- Queso con fibra de trigo homogeneizado. En todas las imágenes las barras de escala corresponden a $10 \mu \mathrm{m}$. 
Resultados y Discusión

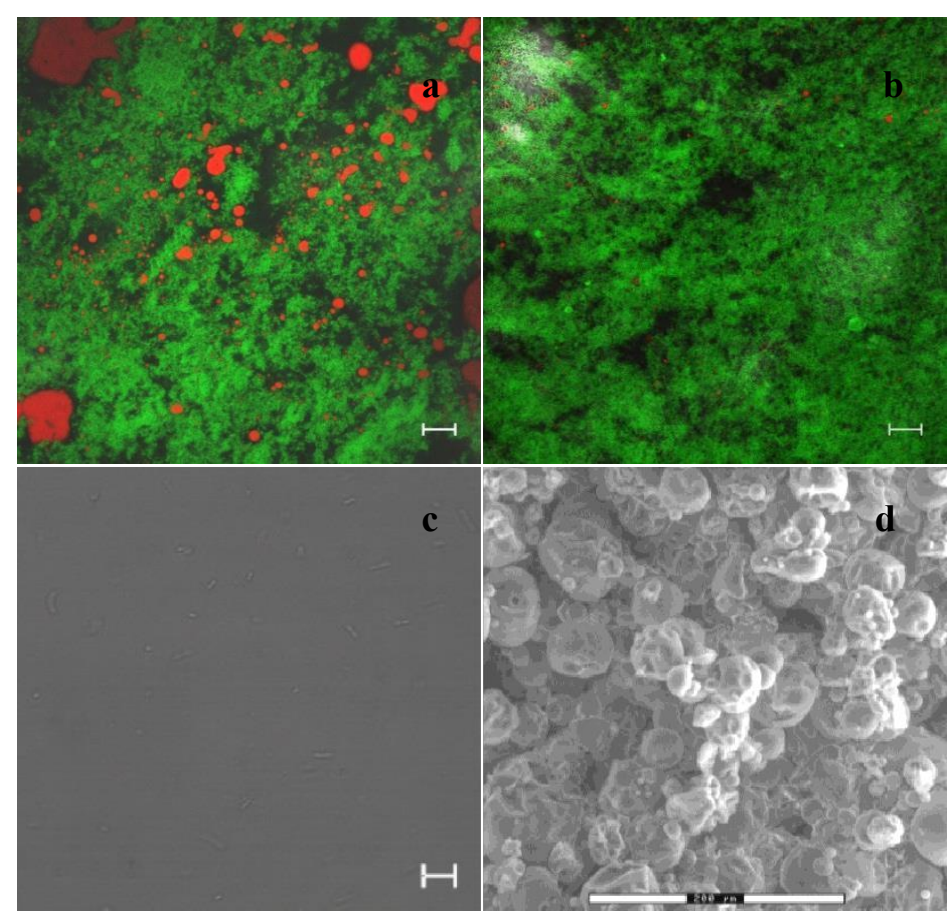

Figura 3.8 a- Fotomicrografía de queso con inulina sin homogeneizar, b- Fotomicrografía de queso con inulina homogeneizado, c- inulina en solución acuosa por microscopía óptica sin fluorescencia $65 \mathrm{x}$. Las barras de escala en las imágenes a, b y c corresponden a $10 \mu \mathrm{m}, \mathrm{d}-$ Inulina por microscopía electrónica ambiental (ESEM). La barra de escala corresponde a 200 $\mu \mathrm{m}$.

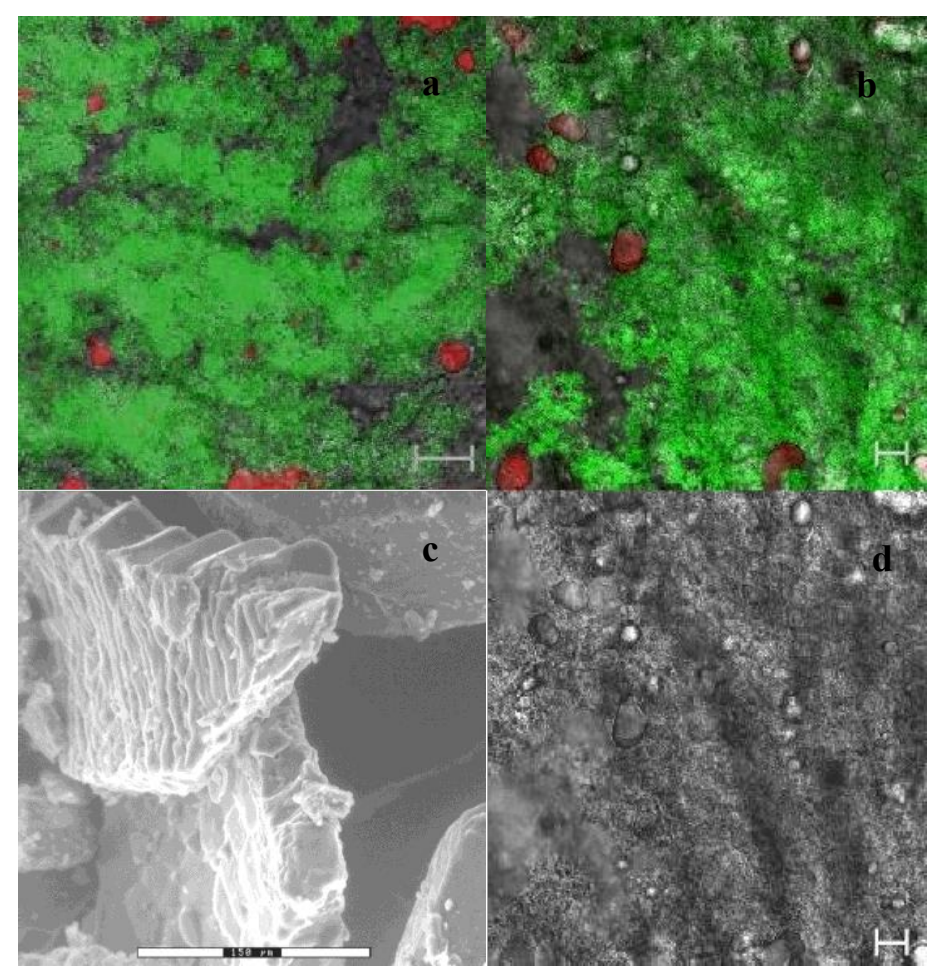

Figura 3.9 a- Fotomicrografía de queso con Psyllium sin homogeneizar, b- Fotomicrografía de queso con Psyllium homogeneizado, c- Psyllium por microscopía electrónica ambiental (ESEM). La barra de escala corresponde a $150 \mu \mathrm{m}$. y d- Fotomicrografía de queso con Psyllium homogeneizado por microscopía óptica $65 \mathrm{x}$ sin fluorescencia. En a, b y d las barras de escala corresponden a $10 \mu \mathrm{m}$. 


\subsubsection{Determinación de las propiedades mecánicas de los quesos elaborados}

\subsubsection{Ensayo a bajas deformaciones}

Durante la elaboración de los quesos, la formación del gel se completó alrededor de las 16-18h, obteniendo la cuajada con un valor de $\mathrm{pH}$ de 4,58 $\pm 0,05$. Algunos investigadores (Roefs y col., 1990; Lucey y col., 2000) observaron que los geles combinados con $\mathrm{pH}>5.15$, presentaban propiedades reológicas esencialmente similares a la de los geles obtenidos solo por cuajado. Mientras que, los geles combinados con $\mathrm{pH}$ final $<5.15$ presentaron propiedades reológicas similares a los geles de caseína obtenidos solo por acidificación. Estudios posteriores (Castillo y col., 2006a, Cooper y col., 2010), revelaron que si bien, el gel producido tiene predominantemente las características reológicas de un gel ácido, las mismas son modificadas en cierto grado por el cuajo adicionado. La formación del cuajo para el queso elaborado en este trabajo se puede estudiar según Sandra y col. (2012), teniendo en cuenta tres estadios. La primera fase involucra la desestabilización ácida y enzimática de la $\kappa$-caseína. El segundo estadio, se refiere a la agregación y a la transición sol-gel de las micelas y el tercer estadio comprende el reordenamiento estructural del gel formado, la sinéresis y maduración del gel (Tranchant y col., 2001). Se han llevado a cabo estudios para intentar explicar el proceso de coagulación en el primer y segundo estadio en geles mixtos desde el punto de vista químico, reológico y microestructural (Lucey y col., 2000 y 2001; Tranchant y col., 2001; Li y Dalgleish, 2006; Castillo y col., 2006a y b; Cooper y col., 2010; Salvatore y col., 2011; Liu y col., 2014). Sin embargo, hay pocos estudios reológicos en geles mixtos una vez que ya ha sido establecida su estructura, es decir luego del tercer estadio. En este trabajo, los ensayos reológicos se han realizado luego del tercer estadio con y sin el proceso de homogeneización, con y sin la adición de sal y fibras de distinto origen.

La reometría oscilatoria dinámica ofrece un método para investigar indirectamente la estructura del queso en un rango escalas de tiempo, de grado de deformación y de temperaturas experimentales. Así, se imponen pequeñas oscilaciones de amplitud sobre la muestra de queso, de tal manera que la deformación o esfuerzo aplicados estén dentro de la región viscoelástica lineal donde cualquier ruptura estructural es en gran parte reversible dentro de la escala de tiempo del experimento. Exceder este límite hace que la estructura del queso cambie y se vuelva a formar en una 
conformación diferente a la inicial al cesar la deformación o el esfuerzo aplicado (Everett y Auty, 2008). En la Figura 3.10 se muestra un barrido de esfuerzo, de todos los efectuados para obtener el rango de viscoelasticidad lineal en los quesos desarrollados. Se observa que la linealidad se mantiene hasta $25 \mathrm{~Pa}$. Por lo tanto, los barridos de frecuencia para los quesos desarrollados, fueron realizados a $10 \mathrm{~Pa}$.
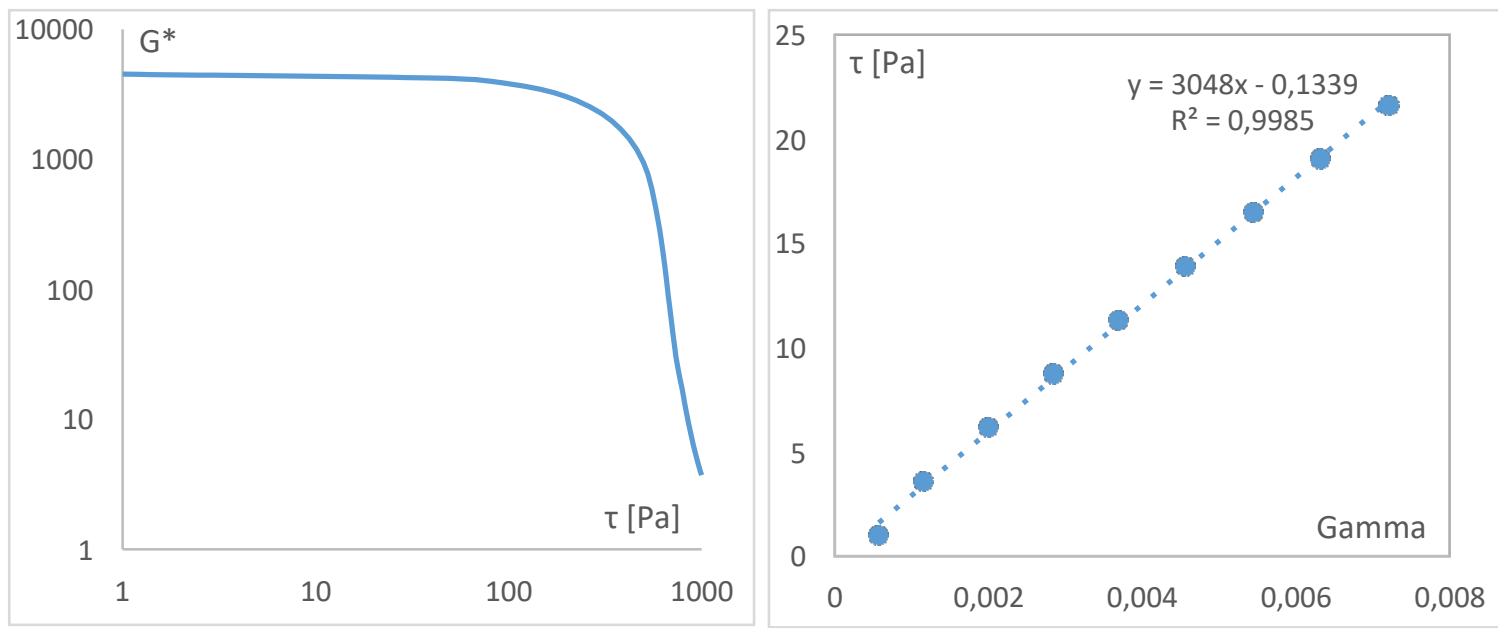

Figura 3.10 Rango de viscoelasticidad lineal a) Módulo complejo $\left(\mathrm{G}^{*}\right)$ vs esfuerzo [Pa] y b) Esfuerzo [Pa] vs deformación del queso homogeneizado con sal sin fibra.

En los perfiles reológicos obtenidos (Figura 3.11), se observa que tanto G' como G' aumentan con el incremento de la frecuencia aplicada, mientras que la viscosidad compleja presenta la tendencia contraria. La relación entre G', $\mathrm{G}^{\prime}(\tan \delta)$, que cuantifica el grado de fluidez de una sustancia, no superó el valor de 0,4 durante todo el barrido de frecuencia para las diferentes formulaciones de quesos. Según Steffe (1996), estos valores obtenidos para tan $\delta$ son intermedios entre una solución concentrada $(1,19)$ y un gel verdadero (0.069). Teniendo en cuenta todas estas características se puede considerar que los quesos elaborados tienen un comportamiento viscoelástico de tipo gel débil ya que coincide con el descripto por Lopes da Silva y Rao (2007) para geles débiles, quienes estudiaron el comportamiento reológico de alimentos fluidos y semisólidos. Además, los valores de G' fueron siempre superiores a los de G” indicando un predominio del comportamiento elástico sobre el viscoso. 


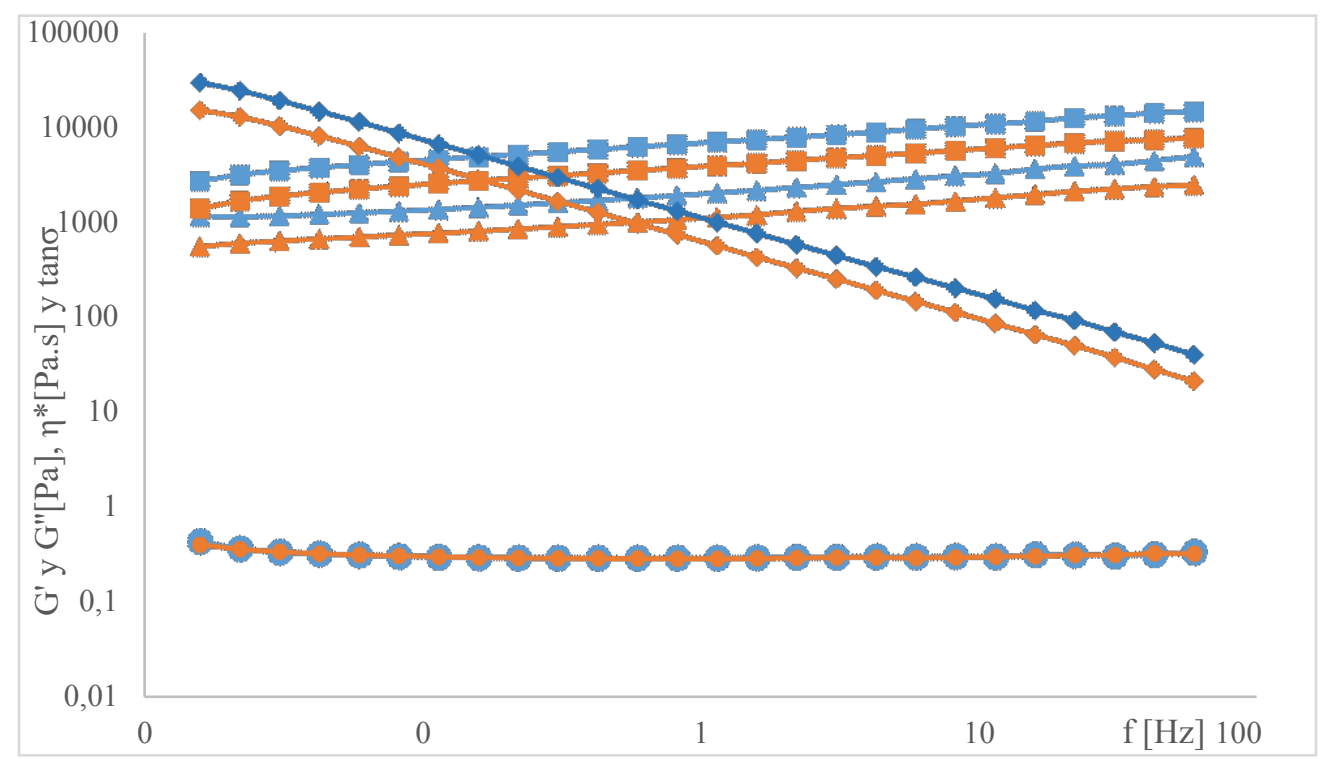

Figura 3.11 Curvas típicas de barridos de frecuencia para los quesos sin sal y sin fibra homogeneizados $(\mathrm{QH})$ y sin homogeneizar $(\mathrm{QSH})$. $\square \mathrm{G}^{\prime}(\mathrm{QSH}), \triangle \mathrm{G}{ }^{\prime}(\mathrm{QSH}),>\eta^{*}(\mathrm{QSH})$ y $\bigcirc \tan \sigma(\mathrm{QSH}) . \quad \mathrm{G}^{\prime}(\mathrm{QH}), \triangle \mathrm{G}^{\prime}(\mathrm{QH}), \eta^{*} \mathrm{y} \bigcirc \tan \sigma(\mathrm{QH})$

Los rangos de valores de G' y G', son similares a los obtenidos por Macku y col. (2008) quienes estudiaron las propiedades reológicas de quesos procesados y a los presentados por Laguna y col., (2017) quienes analizaron la reología de queso untable Philadelphia comercial. Según Li y Dalgleish (2006), el valor del módulo elástico de los geles lácteos depende predominantemente de la concentración de las proteínas, el número y fuerza de las uniones entre ellas y de las fuerzas internas de las mismas. En este sentido cabe destacar que al utilizar leche de oveja que posee un mayor contenido de proteínas que la leche de vaca, se obtienen valores del módulo elástico semejantes a los quesos procesados comerciales elaborados con leche de vaca y que poseen en sus formulaciones aditivos para mejorar e incrementar la fuerza del gel. Por lo tanto, los quesos elaborados en este trabajo de tesis son menos procesados que los encontrados en el mercado del mismo tipo ya que, poseen las mismas características texturales sin la necesidad de incorporar aditivos. Asimismo, se pudieron observar diferencias significativas $(p \leq 0.05)$ en los valores de $G^{\prime}$ y $G^{\prime}$ ' entre los quesos homogenizados y sin homogeneizar, ya que los valores de G' a $1 \mathrm{~Hz}$ de frecuencia, fueron de $7595 \pm 582$ $\mathrm{Pa}$ y $3.241 \pm 593 \mathrm{~Pa}$ para los quesos $\sin$ y con proceso de homogenizado, respectivamente. Con esta misma tendencia, los valores de G' fueron de $2.220 \pm 191$ Pa y $943 \pm 187$ Pa para los quesos sin y con proceso de homogenizado, respectivamente (Figura 3.11). Esto puede atribuirse a que la homogeneización se realiza luego de las etapas de cuajado y desuerado, pudiendo ocasionar la reducción de los 
entrecruzamientos de las caseínas, cuantificándose como un menor valor de G' (Liu y col., 2014) y visualizándose como una red más particulada en la Figura 3.4b. Sin embargo, no hubo diferencias significativas $(\mathrm{p}>0.05)$ en el valor de la $\tan \delta$ entre los quesos con y sin homogeneizado sugiriendo que el proceso aplicado no modifica el grado fluidez de los quesos.

Teniendo en cuenta que estos quesos presentan un comportamiento viscoelástico, es posible modelar los módulos de almacenamiento y de pérdida con la Ley de la Potencia (Ecuaciones 3.1 y 3.2) habitualmente utilizada para describir el comportamiento viscoelástico de alimentos y dispersiones (Augusto y col., 2012).

$$
\begin{aligned}
& \mathrm{G}^{\prime}=a \mathrm{f}^{b} \\
& \mathrm{G}^{\prime}=c \mathrm{f}^{d}
\end{aligned}
$$

En estas ecuaciones $\boldsymbol{a}, \boldsymbol{b}, \boldsymbol{c}$ y $\boldsymbol{d}$ son los parámetros que caracterizan el comportamiento reológico y f [Hz] la frecuencia oscilatoria. $\boldsymbol{a}$ y $\boldsymbol{c}$ también se los conoce como coeficientes de consistencia y $\boldsymbol{b}$ y $\boldsymbol{d}$ son los índices de comportamiento viscoelástico (Augusto y col., 2012). Para cada tipo de queso se determinaron estos parámetros en este trabajo de tesis. Las curvas obtenidas experimentalmente se ajustaron satisfactoriamente al modelo escogido con coeficientes de correlación $r \geq$ 0.958 en cada replicado. En la Tabla 3.5, se presenta la variación de $\boldsymbol{a}, \boldsymbol{b}, \boldsymbol{c}$ y $\boldsymbol{d}$ con respecto a los factores homogeneización, adición de sal y tipo de fibras. Los valores de

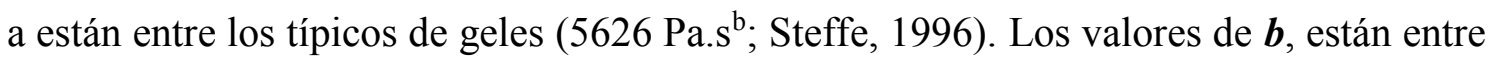
los de una solución concentrada (0.840) y los de los geles verdaderos (0.037). Las soluciones concentradas se caracterizan por presentar entrecruzamientos intermoleculares formados por uniones débiles y al azar mientras que, los geles verdaderos presentan redes ordenadas formadas por uniones de tipo covalente. Los valores del parámetro $c$ obtenidos de las curvas reológicas de los quesos elaborados fueron superiores en un orden de magnitud, a los valores de este parámetro para los geles (344.7 Pa.s ${ }^{d}$ ) informados por Steffe (1996). Los valores de $\boldsymbol{d}$ están entre los de una solución concentrada (0.520) y los de los geles verdaderos (0.0145). Además, se pudo advertir que los valores de los coeficientes de consistencia ( $\boldsymbol{a}$ y $\boldsymbol{c}$ ) obtenidos en este modelado fueron semejantes a los hallados por Nolan y col. (1989) quienes analizaron el comportamiento viscoelástico de quesos mozzarella naturales y de imitación mientras que, los valores de los índices de comportamiento $\left(\begin{array}{lll}b & \text { y } & d\end{array}\right)$ fueron semejantes a los encontrados por Rao y Cooley (1992) quienes evaluaron estos parámetros oscilatorios dinámicos en pastas de tomate. Estas semejanzas permiten reforzar la idea que los 
quesos elaborados en este trabajo de tesis se comportan como geles débiles o fluidos estructurados como también se los denomina.

Tabla 3.5 Variación de $\boldsymbol{a}, \boldsymbol{b}, \boldsymbol{c}$ y $\boldsymbol{d}$ del modelo de la Ley de la Potencia con respecto a los factores homogeneización, adición de sal y tipo de fibras de los quesos con un día de elaboración. SHSS: Sin homogeneizar sin sal; SHCS: Sin homogeneizar con sal; HSS: Homogeneizado sin sal; HCS: Homogeneizado con sal.

\begin{tabular}{lcccc}
\hline & $\boldsymbol{a}\left[\mathrm{Pa} \mathrm{s}^{b}\right]$ & $\boldsymbol{b}$ & $\boldsymbol{c}\left[\mathrm{Pa} \mathrm{s}^{d}\right]$ & $\boldsymbol{d}$ \\
\hline SHSS & & & \\
\hline SF & $7410 \pm 621$ & $0.192 \pm 0.002$ & $2248 \pm 188$ & $0.194 \pm 0.007$ \\
$\mathrm{~B}$ & $9427 \pm 222$ & $0.186 \pm 0.001$ & $2787 \pm 66$ & $0.191 \pm 0.004$ \\
$\mathrm{~T}$ & $6866 \pm 465$ & $0.182 \pm 0.001$ & $2043 \pm 140$ & $0.202 \pm 0.002$ \\
$\mathrm{I}$ & $4590 \pm 118$ & $0.195 \pm 0.001$ & $1444 \pm 40$ & $0.219 \pm 0.002$ \\
$\mathrm{P}$ & $4826 \pm 257$ & $0.186 \pm 0.001$ & $1480 \pm 85$ & $0.173 \pm 0.003$ \\
\hline SHCS & & & \\
\hline SF & $4619.5 \pm 358$ & $0.196 \pm 0.001$ & $1451 \pm 107$ & $0.211 \pm 0.001$ \\
$\mathrm{~B}$ & $8586.5 \pm 274$ & $0.188 \pm 0.001$ & $2573 \pm 47$ & $0.184 \pm 0.018$ \\
$\mathrm{~T}$ & $8462.5 \pm 132$ & $0.186 \pm 0.003$ & $2544 \pm 101$ & $0.197 \pm 0.005$ \\
$\mathrm{I}$ & $4270.0 \pm 495$ & $0.201 \pm 0.002$ & $1380 \pm 151$ & $0.215 \pm 0.001$ \\
$\mathrm{P}$ & $5846.5 \pm 131$ & $0.186 \pm 0.001$ & $1817 \pm 34$ & $0.174 \pm 0.002$ \\
\hline HSS & & & \\
\hline SF & $3122 \pm 672$ & $0.188 \pm 0.006$ & $953 \pm 187$ & $0.198 \pm 0.006$ \\
$\mathrm{~B}$ & $6220 \pm 187$ & $0.193 \pm 0.002$ & $1907 \pm 127$ & $0.194 \pm 0.003$ \\
$\mathrm{~T}$ & $6357 \pm 465$ & $0.185 \pm 0.000$ & $1899 \pm 44$ & $0.185 \pm 0.004$ \\
$\mathrm{I}$ & $4790 \pm 162$ & $0.192 \pm 0.001$ & $1476 \pm 51$ & $0.198 \pm 0.001$ \\
$\mathrm{P}$ & $5122 \pm 178$ & $0.185 \pm 0.002$ & $1520 \pm 92$ & $0.160 \pm 0.003$ \\
\hline HCS & & & & \\
\hline SF & $5572 \pm 689$ & $0.189 \pm 0.001$ & $1694 \pm 206$ & $0.207 \pm 0.000$ \\
$\mathrm{~B}$ & $7360 \pm 437$ & $0.183 \pm 0.002$ & $2159 \pm 704$ & $0.190 \pm 0.014$ \\
$\mathrm{~T}$ & $5330 \pm 548$ & $0.191 \pm 0.002$ & $1639 \pm 123$ & $0.199 \pm 0.000$ \\
& $2574 \pm 91$ & $0.201 \pm 0.000$ & $847 \pm 25$ & $0.212 \pm 0.00$ \\
& $4629 \pm 161$ & $0.187 \pm 0.001$ & $1410 \pm 53$ & $0.166 \pm 0.00$ \\
\hline
\end{tabular}

El análisis estadístico, indicó que el factor homogeneización influye significativamente $(\mathrm{p} \leq 0.05)$ en los valores de los coeficientes de consistencia, al igual que la adición de las distintas fibras. En la Tabla 3.5, se puede observar que $a$ y $c$ son mayores para los quesos sin homogeneizar. También en la Figura 3.11 se puede notar que las curvas de G' y G', presentan valores más elevados en los quesos sin homogeneizar que en los quesos sometidos a un proceso de homogeneizado. Esto puede deberse a que en los quesos homogenizados la estructura de gel se vuelve más débil, como consecuencia del tratamiento mecánico. En relación a las fibras, las mismas 
influyen significativamente $(\mathrm{p} \leq 0.05)$ en los valores de $\boldsymbol{a}$ y $\boldsymbol{c}$. Los quesos con fibra de trigo presentaron los mayores valores de $\boldsymbol{a}$ y $\boldsymbol{c}$, seguidos por los quesos con fibra de bambú. No hubo diferencias significativas entre los quesos sin fibra y los quesos con psyllium. Los quesos con inulina presentaron los menores valores de los coeficientes $\boldsymbol{a}$ y c de consistencia. En la Figura 3.12, en la cual se muestran las curvas de G' y G', de los quesos con sal, sin homogeneizar con las distintas fibras. Se puede observar que las curvas de los quesos con fibras de trigo y bambú poseen los valores más elevados de G' y G', en todo el barrido de frecuencia. Las curvas de los quesos sin fibra y con inulina mostraron los valores más bajos. En cambio, la curva del queso con psyllium presenta valores intermedios. Estas diferencias pueden explicarse teniendo en cuenta la composición química y la solubilidad de las distintas fibras. Las fibras de trigo y bambú poseen un alto contenido de celulosa y son insolubles. La inulina es totalmente soluble y el psyllium tiene componentes químicos tanto solubles como insolubles. Además, cabe mencionar que en las curvas de los quesos con las fibras de trigo y bambú, G' aumenta ligeramente con la frecuencia, mientras que G', permanece constante o disminuye ligeramente a bajas frecuencias ( $f<0,1 \mathrm{~Hz}$ ) para luego aumentar hasta el final del barrido. Este comportamiento a bajas frecuencias es típico de materiales altamente estructurados Bayod y col. (2008).

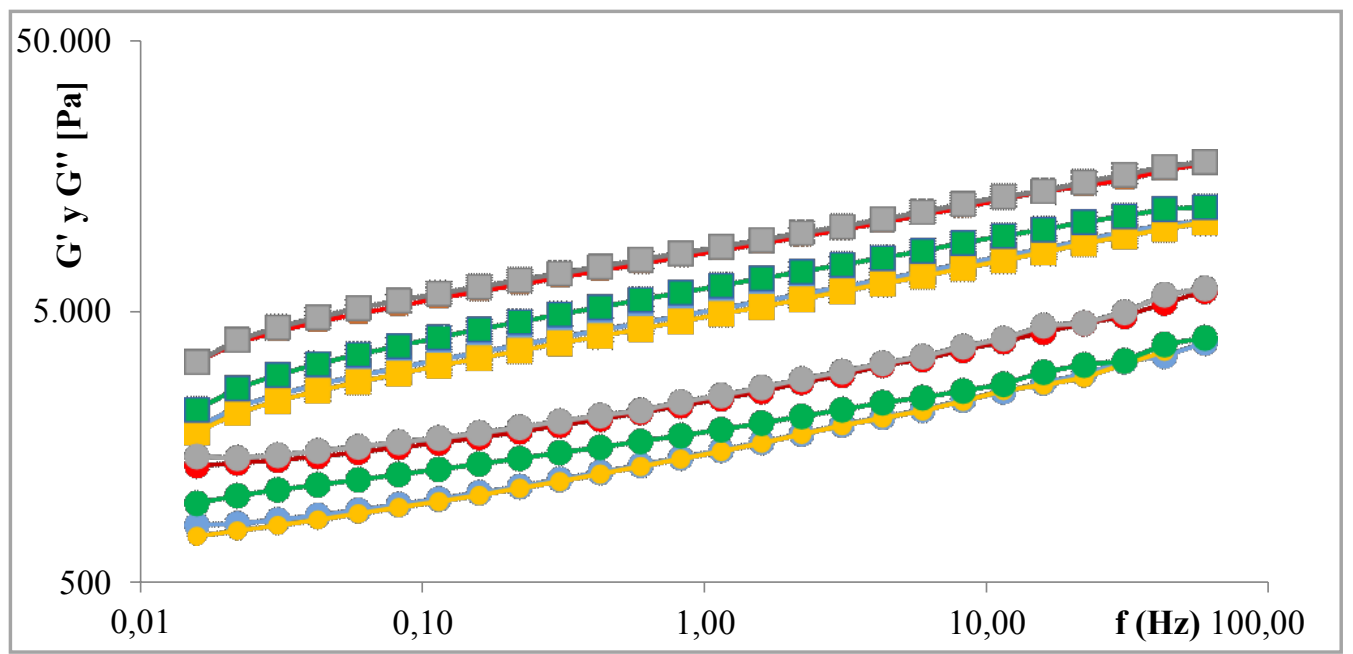

Figura 3.12 Gráficos típicos de G’ ( $\square$ ) y G” ( $($ ) en función de la frecuencia, para los quesos sin homogeneizar con sal con los diferentes tipos de fibras adicionadas.

Queso sin fibra $\square$ Queso con fibra de bambú $\square$ Queso con fibra de trigo Queso con inulina $\square$ Queso con psyllium

Los valores del índice de comportamiento elástico $(\boldsymbol{b})$ presentan un rango entre 0,18 - 0,20 que corresponde según Bayod y col. (2008) a geles conformados por partículas agregadas, que es el caso de los quesos elaborados en este trabajo de tesis, 
como se pudo observar en las imágenes obtenidas con el microscopio confocal. Asimismo, se encontró que este índice variaba con la adición de sal y las distintas fibras. Con respecto al factor sal, los valores de $\boldsymbol{b}$ fueron superiores para los quesos con sal. En la Figura 3.13, puede observarse que para los quesos homogeneizados con sal las curvas presentan valores superiores que las de los quesos homogeneizados sin sal. Esto puede explicarse teniendo en cuenta que la aplicación de sal hasta al menos 1,6\% induce el incremento de tamaño de las caseínas provocando la adsorción y absorción de humedad por la matriz de proteica, aumentando la consistencia de los quesos con sal según Rowney y col. (2004). Con respeto a la utilización de las distintas fibras, el índice de comportamiento elástico (b) fue superior para los quesos con inulina y sin fibra, sin diferencias significativas entre ellos. No hubo diferencias significativas para este índice entre los quesos con fibras de bambú, trigo y psyllium, siendo menores que los obtenidos para los quesos sin fibra y con inulina.

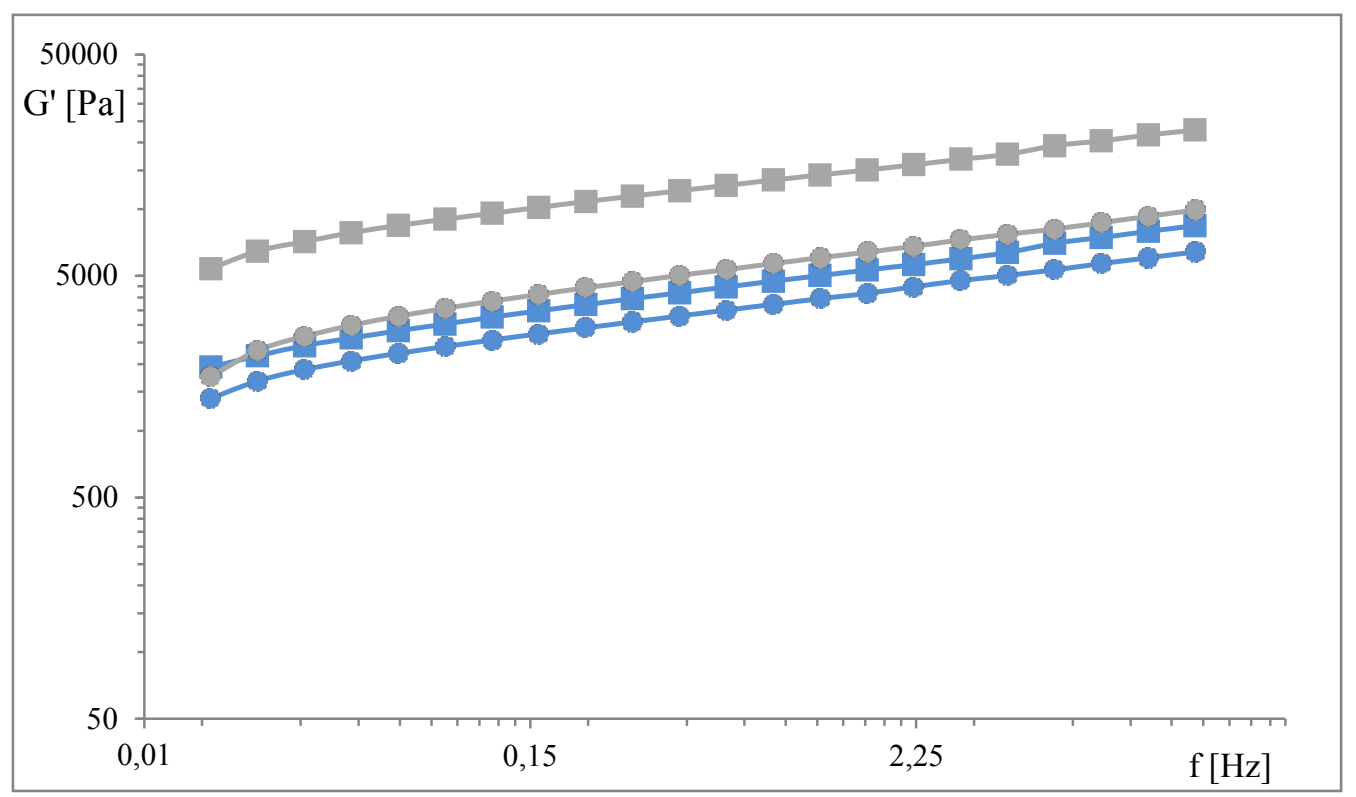

Figura 3.13 Curvas típicas de G' para los quesos homogeneizados sin fibra con $(\square)$ y $\sin (0)$ sal y con fibra de trigo con $(\square)$ y $\sin (-$ sal

Los valores del índice $\boldsymbol{d}$ (Ecuación 3.2), variaron únicamente con la adición de las distintas fibras con el mismo patrón según el tipo de fibra que para el índice b, con la excepción de que los quesos con psyllium presentaron los menores valores diferenciándose significativamente del resto de los quesos con fibras $(\mathrm{p} \leq 0.05)$.

\subsubsection{Ensayo a grandes deformaciones}


Considerando que para los consumidores la textura de los quesos es tan importante como el sabor, el objetivo de utilizar el ensayo de extrusión-compresión en este trabajo de tesis fue evaluar el umbral de fluencia de los quesos que está asociado en muchos trabajos científicos (Van Vliet,1991; Gunesakaran y Ak, 2003), con la capacidad de untar el queso sobre una superficie sólida como pan o galletitas, tanto a temperatura ambiente como a temperatura de refrigeración que es la forma en que se consume habitualmente este tipo de queso. Ésta es la característica reológica más distintiva de este producto y es consecuencia de la consistencia semisólida que posee, que a su vez está dada por su estructura que como se ha descripto en las secciones anteriores, está relacionada principalmente con el contenido de proteínas y de calcio de la leche utilizada, así como también, con el proceso de elaboración (Park 2007; Tawongsa y col., 2014; Ramaswamy y col., 2015).

Los perfiles típicos obtenidos del ensayo de compresión-extrusión para los quesos sin homogeneizar sin sal con las diferentes fibras pueden observarse en la Figura 3.14. Se muestra solo una curva para cada queso con fibra elaborado para no dificultar la visualización de los perfiles con los replicados, ya que son muy similares y es de interés comentar la forma de las curvas adquiridas para conectarla con sus propiedades mecánicas. Típicamente, la forma y la magnitud de la curva de compresión-extrusión está influenciada por la viscoelasticidad de la muestra, el comportamiento de ruptura de la misma, la velocidad de deformación, la temperatura de la muestra al momento del ensayo, el tamaño de la celda de prueba, la cantidad y homogeneidad de la muestra (Voisey y col., 1972; Bourne, 2002). En este ensayo, la velocidad de deformación, la temperatura de la muestra, el tamaño de la celda y la cantidad de muestra, se mantuvieron constantes, por lo tanto, las diferencias que puedan observarse van a ser debidas a la viscoelasticidad y al comportamiento de ruptura de los quesos analizados. La homogeneidad de la muestra es la propia del queso analizado y también se mantuvo constante mediante la repetición del proceso de obtención del queso en cada elaboración. Todas las curvas obtenidas en este ensayo, muestran las siguientes zonas que concuerdan con las descriptas por Bourne (2002) y están ejemplificadas en la curva del queso con psyllium. De A a B, el queso se deforma y se comprime cada vez más para empacarse en el espacio decreciente disponible debajo del émbolo descendente; casi no hay ruptura ni fractura de la estructura del queso. Aproximadamente en el punto $\mathrm{B}$, el queso se empaqueta en forma sólida y el líquido comienza a escaparse desde los 
intersticios de la red de proteínas y solo quedan muy pequeñas cantidades de aire atrapado en la red.

Asimismo, la fuerza aumenta de forma abrupta de $\mathrm{B}$ a $\mathrm{C}$ y expulsa más suero en el proceso. La zona B-C representa la fuerza creciente que se aplica a una mezcla casi incompresible de sólido y líquido que produce una deformación elástica e instantánea, es decir que la muestra tiene la posibilidad de recuperar su estructura y forma, si la fuerza que se está aplicando se retira. En el punto C, la estructura del queso comienza a romperse y fluye a través del espacio anular, y este proceso continúa hasta el punto $\mathrm{E}$ cuando la placa de compresión invierte la dirección y la fuerza cae a cero. El punto C proporciona la fuerza necesaria para comenzar el proceso de extrusión. Es el umbral de fluencia y se describe como la fuerza necesaria que hay que superar para que la muestra comience a fluir. A partir de C comienza la deformación permanente del queso, es decir que el queso no recupera su estructura si se retira la fuerza aplicada. En el punto D, se alcanza la fuerza máxima de extrusión y comienza la deformación viscosa del queso en la zona D-E. Esta zona de meseta, muestra la fuerza necesaria para continuar la extrusión y el flujo de la muestra. Como en la mayoría de los alimentos, la zona D-E es horizontal o casi. La irregularidad de la zona D-E es causada por variaciones en la firmeza o dureza de las partículas que están pasando a través de la zona del anillo en cualquier momento particular. De acuerdo con Voisey y col. (1972), estos dos comportamientos diferentes pueden indicar dos estructuras diferentes. Una zona D-E aproximadamente horizontal o con descenso muy lento, indica una combinación de cizallamiento, extrusión y adhesión a las paredes del recipiente, que ocurren simultáneamente durante la extrusión de los quesos analizados. Por el contrario, si la fuerza aumenta constantemente a medida que avanza la extrusión, indica una compresión adicional de la muestra debido posiblemente a la expulsión de más suero por parte de la red proteica, además de la combinación de adhesión, extrusión y cizallamiento. Se pudo observar que todos los perfiles de las curvas obtenidos presentaron las mismas zonas ya descriptas, sin embargo hubo diferencias significativas en los valores del umbral de fluencia con respecto a la adición de las fibras, la adición de sal y a la utilización del proceso de homogeneizado. Cabe mencionar, no obstante, que si bien para la gran mayoría de las curvas obtenidas la pendiente de la zona D-E fue aproximadamente horizontal, los quesos $\sin$ homogeneizar, sin sal y $\sin$ fibra presentaron una pendiente de aumento compatible con la expulsión de más suero por parte de su red proteica. 


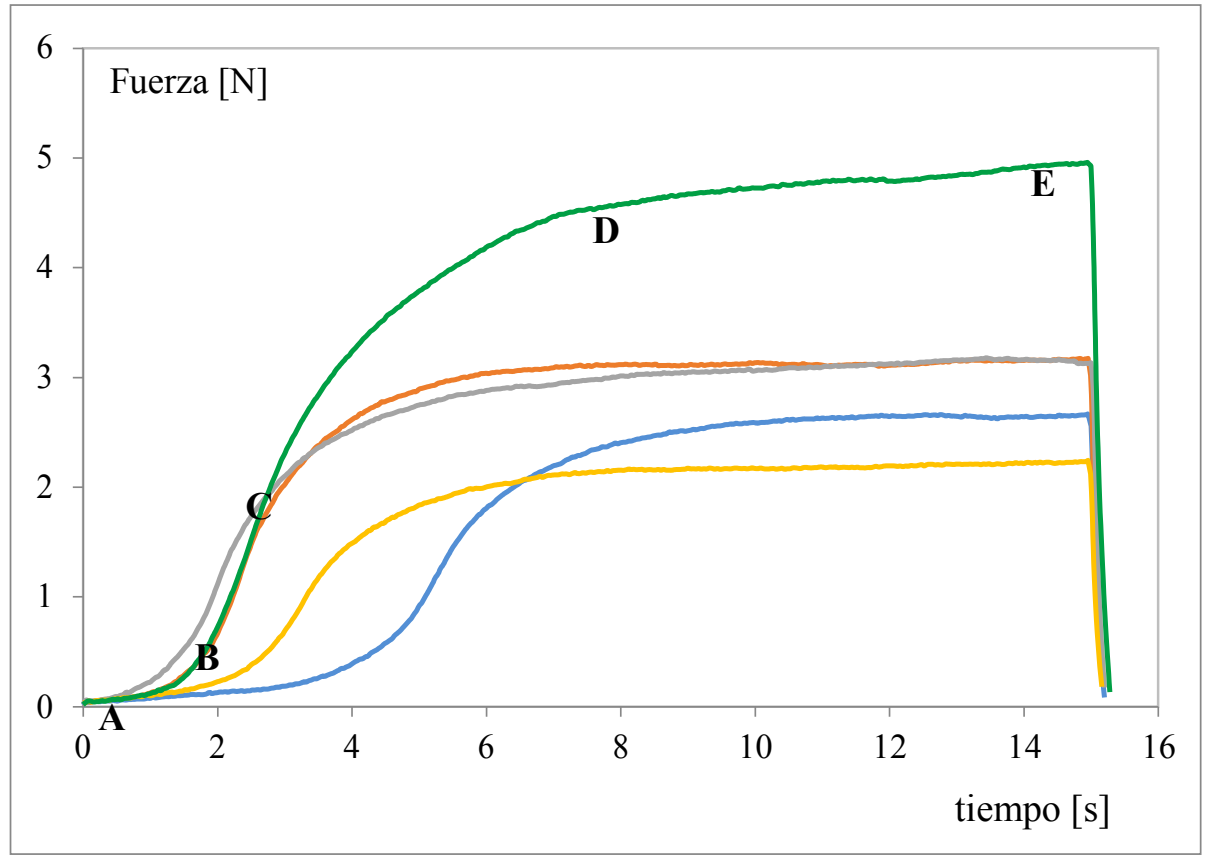

Figura 3.14 Gráficos de fuerza vs tiempo del ensayo de compresión-extrusión para los quesos sin homogeneizar sin sal, con y sin fibra, recién elaborados.

Queso sin fibra $\square$ Queso con fibra de bambú $\square$ Queso con fibra de trigo Queso con inulina $\square$ Queso con fibra de Psyllium

Considerando la presencia de las diferentes fibras, se pudo observar que los quesos sin fibra y con fibras de trigo y bambú no tuvieron diferencias significativas en el valor del umbral de fluencia. Los quesos con inulina presentaron los valores más bajos y los quesos con psyllium los valores más altos para el umbral de fluencia. Estas diferencias pueden ser explicadas teniendo en cuenta, las propiedades fisicoquímicas de las distintas fibras. La inulina es totalmente soluble y además muy higroscópica lo que puede contribuir a tomar la humedad ambiente y disminuir la consistencia del queso. En cambio el psyllium al tener la habilidad de formar un gel mucilaginoso muy fuerte con gran capacidad de retención de agua eleva mucho el umbral de fluencia de los quesos que lo contienen. La fracción bioactiva del psyllium son los polisacáridos denominados hemicelulosas, responsables de sus características funcionales. Éstas se clasifican como arabinoxilanos, cuyo esqueleto consiste en unidades de xilosa con cadenas laterales compuestas por unidades de arabinosa y xilosa (Chan y Wypyszyk, 1988; Theuwissen y Mensink, 2008).

Con respecto a la adición de sal, el análisis estadístico dio como resultado que los quesos con la adición de $0.3 \%$ de sal presentaron un mayor umbral de fluencia que los quesos sin el agregado de la misma (Figura 3.15). Esto puede deberse, como se mencionó para el ensayo a bajas deformaciones, a que la sal induce el incremento de tamaño de las caseínas provocando la adsorción y absorción de humedad por la matriz 
de proteica, aumentando la consistencia de los quesos con sal Rowney y col. (2004). Con respecto a la homogeneización, se observó que este proceso disminuyo el umbral de fluencia de los quesos (Figura 3.16). Esto puede explicarse teniendo en cuenta que la homogeneización hace que las proteínas estén más particuladas, es decir, altera la red proteica y la hace más débil, lo que se observó en las fotomicrografías y en los parámetros obtenidos en el ensayo a bajas deformaciones.

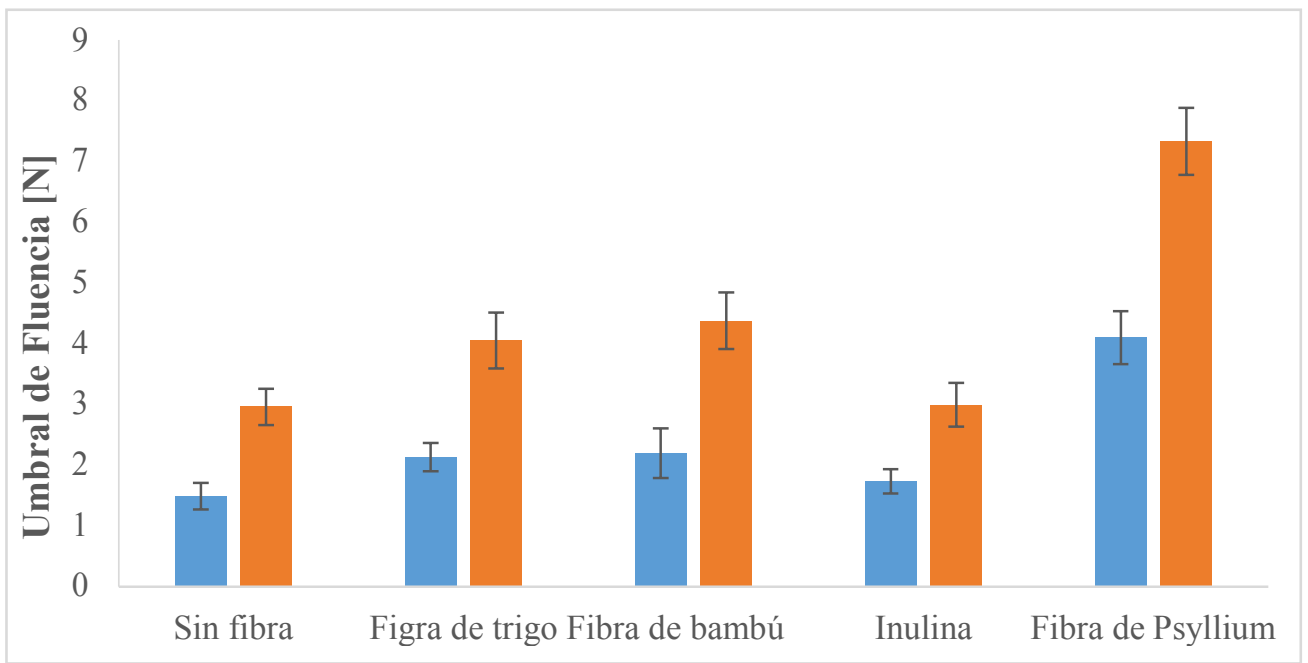

Figura 3.15 Umbral de fluencia para los quesos homogeneizados con y sin fibra, con y sin sal. Quesos sin sal $\square$ Quesos con sal

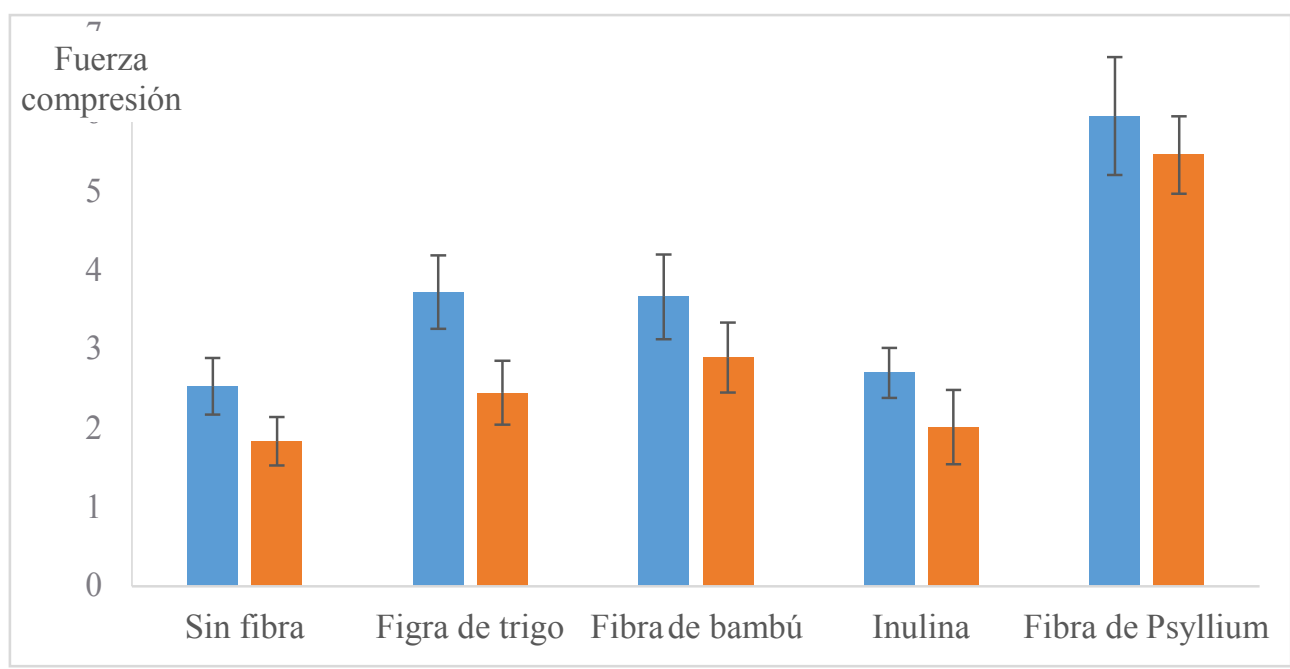

Figura 3.16 Umbral de fluencia para los quesos sin sal con las distintas fibras utilizadas, con respecto a la realización o no del proceso de homogeneización Queso sin homogeneizar $\square$ Queso homogeneizado

\subsubsection{Análisis sensorial de aceptabilidad general}

El análisis sensorial es una herramienta muy importante y cada vez más utilizada en el desarrollo de nuevos productos alimenticios y dentro de este, el análisis hedónico 
en particular brinda a los desarrolladores de nuevos productos una idea sobre la posibilidad de éxito en la comercialización de un nuevo producto o un producto con algún tipo de variación en su elaboración y presentación (Cruz y col., 2011). Los resultados de los puntajes obtenidos para cada atributo y del análisis estadístico de los mismos se detallan a continuación.

Los puntajes promedio de aceptabilidad general (Figura 3.17), variaron desde 5,13 en los quesos con fibra de psyllium (menor puntaje) hasta 6,13 en los quesos con inulina. Si bien el valor más alto en la escala del ensayo es 9, estos valores promedio obtenidos, pueden considerarse como buenos puntajes, ya que los consumidores otorgan un puntaje diferente a cada tipo de alimento. Aquellos alimentos que tienen mayor aceptabilidad entre la población como por ejemplo, el chocolate y el dulce de leche, van a tener puntajes más altos en el ensayo de aceptabilidad, independientemente del proceso o ingrediente que se quiera estudiar. En el caso del dulce de leche, se encuentra en un rango de 6,50-7,50 en aceptabilidad general (Dello Staffolo y Pinotti, 2017). Además, hace aproximadamente 3-4 décadas, los productos rotulados como saludables (que por lo general eran bajas calorías), tenían una menor aceptabilidad que los productos regulares, sin embargo, este comportamiento está cambiando (Bølling Johansen, 2010; Bølling Johansen y col., 2010; McCrickerd y Forde, 2016). En los últimos años, la tendencia mundial es un aumento de la aceptabilidad y del consumo de productos saludables (Nielsen, 2015).

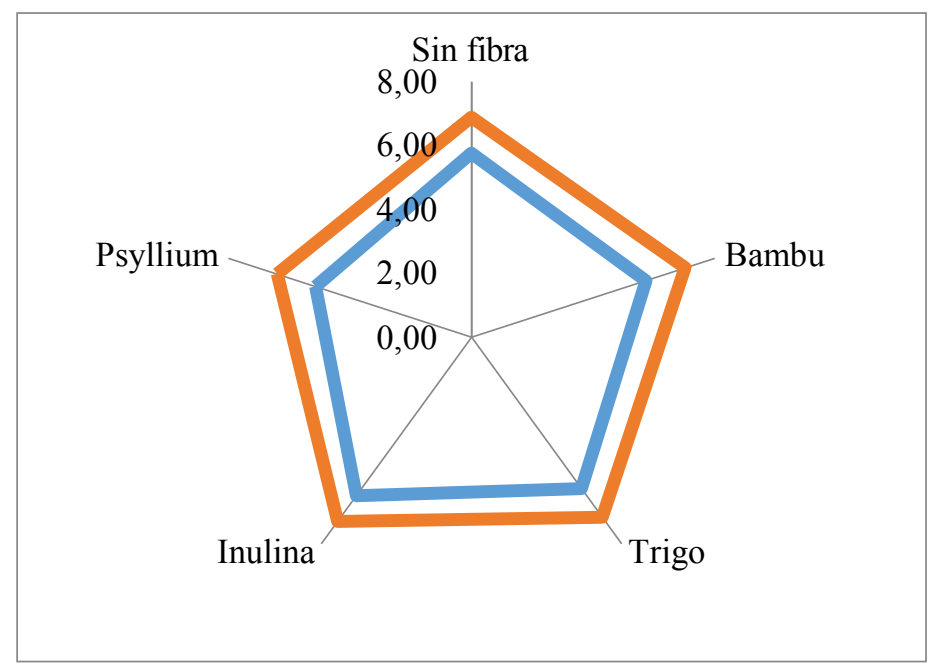

Figura 3.17 Variación de los atributos de color $\square$ y aceptabilidad general $\square$ con los distintos tipos de fibras adicionadas.

Desde el punto de vista del análisis estadístico, el proceso de homogeneización realizado y la adición de sal no causaron diferencias significativas $(p>0.05)$ en la 
aceptabilidad de los quesos elaborados. Solamente, el factor fibra presentó diferencias significativas $(\mathrm{p} \leq 0.05)$ en el atributo aceptabilidad. El queso sin fibra, y los quesos con fibras de trigo, inulina y bambú no manifestaron diferencias entre ellos, por lo cual estas fibras, pueden ser utilizadas para aportarle una característica más saludable al producto, sin afectar la aceptabilidad del consumidor. En contraste, la adición de psyllium mostró una diferencia significativa en relación a las otras fibras y al queso sin fibra, presentando una aceptabilidad menor. Este resultado puede ser explicado teniendo en cuenta que el psyllium es la fibra utilizada en este trabajo que presenta las partículas de mayor tamaño. Appleqvist y col. (2015) estudiaron dispersiones en agua de fibra de zanahoria preparadas con distintos tamaño de partícula y con diferentes procesos y observaron que las partículas de fibra de zanahoria con un rango de tamaño límite de 30-400 $\mu \mathrm{m}$ no fueron percibidas como granuladas y no fueron mecánicamente detectadas como partículas individuales durante su ingestión. Es probable entonces, que el psyllium que posee una proporción importante de partículas que superan este límite, estaría siendo detectado por los consumidores que participaron del ensayo sensorial y podría ser una causa de disminución en el puntaje del atributo aceptabilidad.

Para interpretar porque el proceso de homogeneizado utilizado en la elaboración de los quesos no causó diferencias significativas en la aceptabilidad general podría considerarse que en el existen en el mercado local quesos untables con tamaño de partículas que pueden ser percibidos por nuestro paladar y otros que no, elaborados por dos marcas comercialmente líderes en este rubro, que tienen entre los consumidores una buena aceptabilidad. En relación a la adición de sal, tampoco se han puesto de manifiesto diferencias significativas en la aceptabilidad general. Esto puede ser debido, por una parte, a que la adición de sal fue baja $(0,3 \%)$. Por otro lado, hay una tendencia mundial al consumo de alimentos con menor contenido de sal debido a las fuertes campañas de concientización (OMS/OPS, 2007) que hacen que los consumidores estén disminuyendo el uso de sal y aceptan cada vez más las versiones con menos sodio de los alimentos tradicionales debido posiblemente a una readaptación del paladar hacia la aceptación de alimentos con menor sabor salado.

Respecto al color de los quesos elaborados se obtuvieron los mismos resultados que para la aceptabilidad general: el queso con fibra de psyllium obtuvo el menor puntaje y no hubo diferencias significativas entre el queso sin fibra y los quesos con las demás fibras (Figura 3.17). Esto podría explicarse considerando a que los consumidores se encuentran habituados a consumir quesos untables blancos, cuando no son 
saborizados. El queso con psyllium presenta un color blanco hueso, que no es habitual en el mercado y podría haber provocado la merma del puntaje. Según el análisis realizado, el proceso de homogeneización y la adición de sal, no influyeron en los puntajes obtenidos para el atributo color.

En cuanto al atributo sabor no se observaron diferencias significativas con respecto a los tres factores estudiados: homogeneización, adición de sal y agregado de diferentes fibras. Este resultado es muy positivo ya que valida la incorporación de fibras de distinto origen en el mercado local. Es interesante mencionar que la interacción doble entre el homogeneizado y la sal fue significativa. En particular, mostraron mayor puntaje los quesos sin homogeneizar con sal, pudiendo esto deberse, a que es diferente la percepción por parte de los consumidores del sabor salado si la textura de los quesos es particulada como es el caso de los quesos sin homogeneizar, o la textura es más continua o suave como es el caso de los quesos homogeneizados.

En relación a los atributos textura y a la untabilidad, se observaron diferencias significativas con el agregado de las distintas fibras y con la homogeneización. El proceso de homogeneización aportó el mayor puntaje a la aceptabilidad de la textura y de la untabilidad de los quesos desarrollados, tal como puede observarse en las Figuras 3.18 y 3.19. Es decir que la introducción del proceso de homogeneización en la elaboración de los quesos, fue adecuado para lograr una mayor aceptabilidad de los atributos textura y untabilidad. En cuanto a la adición de las fibras se observó el mismo patrón que para los atributos anteriores: el queso con psyllium obtuvo el menor puntaje y no hubo diferencias significativas entre los quesos sin fibra y los quesos con fibras de bambú, trigo e inulina.

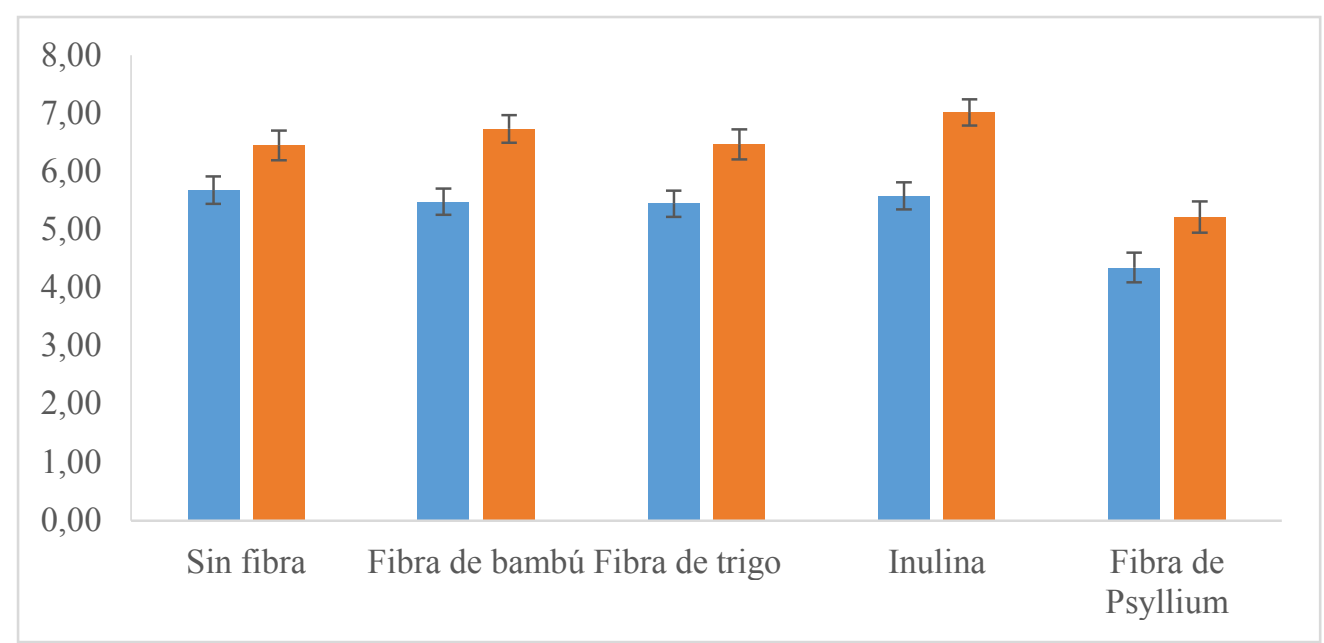

Figura 3.18 Variación del atributo textura con el homogeneizado para los quesos con los distintos tipos de fibras adicionados.

Queso sin homogeneizar $\square$ Queso homogeneizado 


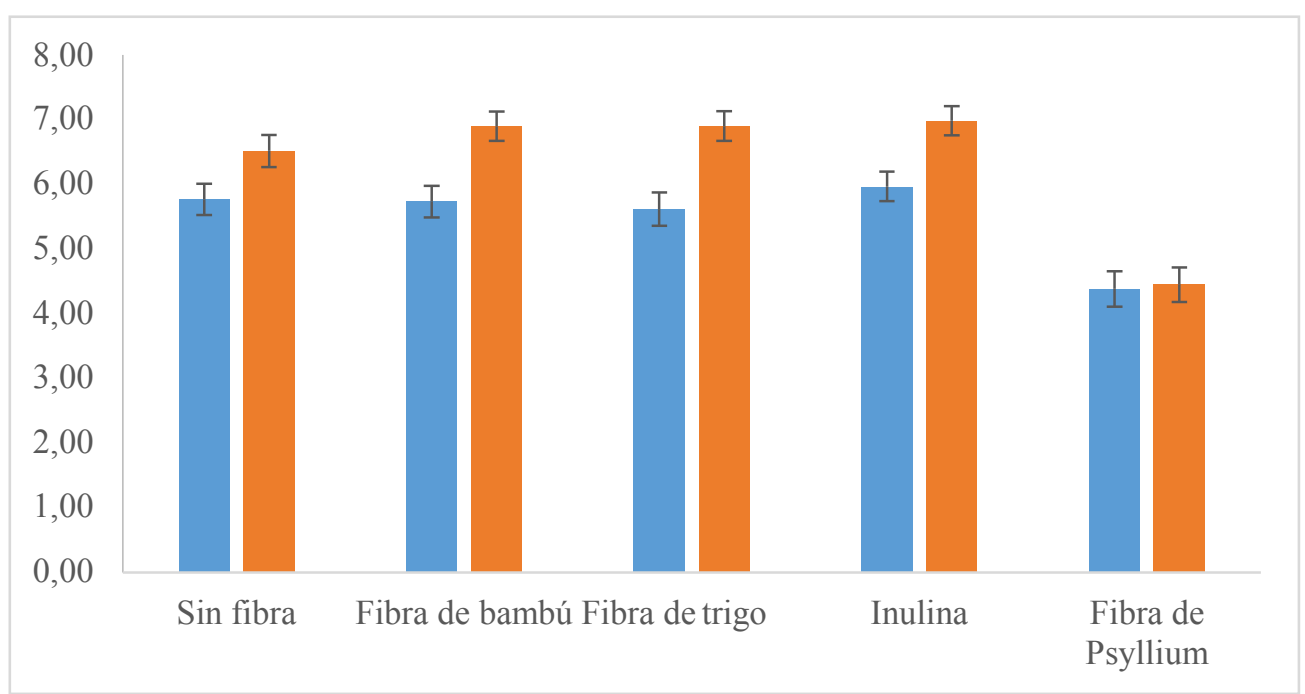

Figura 3.19 Variación del atributo untabilidad con el homogeneizado para los quesos con los distintos tipos de fibras adicionados (Sin fibra- Fibra de bambú- Fibra de trigo- InulinaPsyllium) $\square$ Queso sin homogeneizar $\square$ Queso homogeneizado

\subsection{Evaluación de la calidad de los quesos funcionales elaborados durante el almacenamiento congelado.}

Debido a la naturaleza estacional de la producción de leche de oveja, todos los años suele haber un excedente de leche de oveja en otoño y primavera, que se destina a la fabricación de queso, lo que provoca un descenso de los precios y afecta negativamente a la comercialización y venta de quesos de leche de oveja sobre todo en la zona del mediterráneo europeo, donde se consumen muchos quesos de leche de oveja. Para aliviar esta situación general y regular este mercado, se han realizado una serie de pruebas relacionadas con el almacenamiento, usando una gama de procedimientos tales como: la liofilización de la leche, que condujo a deficiencias en el sabor de los quesos evaluados (FIL, 1982; Alvarenga y col. 2013); o el uso de leche congelada, lo que ha provocado en algunos casos, la aparición de cristales de lactosa y agregados de caseína. También, se observó que la congelación de leche concentrada indujo la incorporación de fósforo y calcio en la caseína micelar, lo que provocó alteraciones drásticas en su estructura y dio lugar a la formación de precipitados de caseína y a la floculación de proteínas (Muir, 1984). Además, se ha informado (Voutsinas y col., 1995) que el queso Feta preparado a partir de leche de oveja congelada no filtrada, dio lugar a importantes deficiencias organolépticas.

En cambio, la congelación de la cuajada de queso se ha considerado tradicionalmente la alternativa más adecuada para regular el mercado del queso 
(Veisseyre, 1980); y se han llevado a cabo numerosos estudios sobre diferentes quesos madurados a partir de cuajada congelada (Alichanidis y col., 1981; Fontecha y col., 1994; Bertola y col., 1996). Sin embargo, algunos pocos investigadores han estudiado el efecto de la congelación en quesos completamente maduros y parcialmente maduros, a pesar de que este método de preservación se usa de forma rutinaria en muchas fábricas de quesos (Prados y col., 2006). Lo más notables de estos trabajos se han focalizado en aspectos específicos como las características sensoriales, funcionales y químicas de los quesos de tipo Gorgonzola y Provolone (Ottogalli y Rondinini, 1974), Mozzarella (Califano y Bevilacqua, 1999; Chaves Viotto y Grosso, 1999; Oberg y col., 1992) у Cheddar (Kasprzak y col., 1994; Sen y Gupta, 1987). Asimismo, Luck (1977) llegó a la conclusión de que el almacenamiento congelado era adecuado para el queso crema, el queso Camembert no madurado y el queso Brick, pero no para Gouda o queso Cheddar. Además, Cervantes y col. (1983) concluyeron que la congelación por una semana y la descongelación no afectaron la calidad del queso Mozzarella que fue evaluado en sus propiedades mecánicas y sensoriales. Igualmente, los estudios del efecto de la velocidad de congelación y la duración del almacenamiento congelado en las características sensoriales (Tejada y col., 2000), y en las características químicas y microbiológicas (Tejada y col., 2002) de los quesos maduros "Los Pedroches" (un queso casero semiduro hecho con leche cruda de oveja de España) concluyeron que este queso, podría almacenarse a $-20{ }^{\circ} \mathrm{C}$ durante aproximadamente 6 meses sin ninguna alteración significativa de las características estudiadas. En este mismo sentido, Park y col. (2004) mostraron que desde el punto de vista microbiológico es seguro consumir quesos de leche de cabra congelados durante seis meses y también observaron en otro trabajo, que no disminuye la calidad sensorial de quesos de leche de cabra congelados durante seis meses (Park y Lee, 2006). Además, un trabajo realizado con leche de oveja y queso tipo cheddar elaborado con leche de oveja por Zhang y col. (2006) también reveló que es posible el almacenamiento congelado desde el punto de vista de la composición química. Recientemente, un estudio de almacenamiento congelado durante 5 años en queso de leche de cabra (Park 2013) indicó que no se observaron grandes cambios en las características sensoriales en el periodo estudiado, sugiriendo la posibilidad de un almacenamiento congelado más prolongado. Por el contrario, hay estudios que muestran que el almacenamiento congelado no fue adecuado para queso de leche de cabra de formato pequeño (Pino, 2005), ya que produjo una textura desmenuzable al final del almacenamiento. A su vez, también se han observado pequeñas modificaciones durante 
el almacenamiento congelado de quesos, como por ejemplo el contenido de ácidos orgánicos y las propiedades sensoriales (Park y Drake, 2005), así como también en la proteolisis (Prados y col., 2006). Por consiguiente, en vista de todos estos resultados, el antiguo concepto de que el queso no debe congelarse podría reexaminarse útilmente para cada variedad de queso y condiciones de elaboración.

\subsubsection{Medición de pH}

La leche de oveja presentó un $\mathrm{pH}$ promedio de 6,60 \pm 0,03. Luego de la adición del fermento, inmediatamente antes de la incorporación del coagulante, el $\mathrm{pH}$ promedio se encontró en 6,40 $\pm 0,02$. Los resultados del análisis estadístico, indicaron que el pH solo varió significativamente $(\mathrm{p} \leq 0,05)$ con el tiempo de almacenamiento y con el proceso de homogeneizado.

El pH obtenido osciló, en promedio, entre 4,61 y 4,24 durante los 3 meses de almacenamiento. Pudo observarse una disminución en las medidas de $\mathrm{pH}$ hasta los 30 45 días, y a partir de los 45-60 días, el $\mathrm{pH}$ aumentó hasta el final del almacenamiento (Figura 3.20). La disminución del $\mathrm{pH}$ de los quesos durante el almacenamiento congelado puede estar relacionada con la liberación de ácidos grasos libres de los lípidos por la actividad enzimática que no se detiene durante la congelación. A su vez, se conoce que se produce criodesestabilización y dispersión de lípidos desde los glóbulos de grasa por la ruptura de la capa lipoproteica que los rodea durante el congelamiento, almacenamiento y descongelación (Cole y col., 1959, Doan y Keeney, 1965). Con el proceso de homogeneización del queso, se produjo la reducción del tamaño de los glóbulos de grasa, como pudo observarse en las micrografías obtenidas con el microscopio laser confocal (Figura 3.4). Este efecto también fue informado en leche fluida (Ong y col., 2010). Esta reducción en el tamaño de los glóbulos de grasa debida a la ruptura y reorganización en glóbulos más pequeños, puede producir la liberación de triacilgliceroles y ácidos grasos libres contenidos dentro del glóbulo de grasa y causar una disminución del $\mathrm{pH}$. Cabe mencionar, que no se observaron diferencias significativas entre los valores de $\mathrm{pH}$ de los quesos recién elaborados y los quesos con un día de almacenamiento congelado, por lo tanto el proceso de congelamiento utilizado no introdujo modificaciones en la calidad de los quesos y las variaciones detectadas se deben únicamente al tiempo de almacenamiento. 


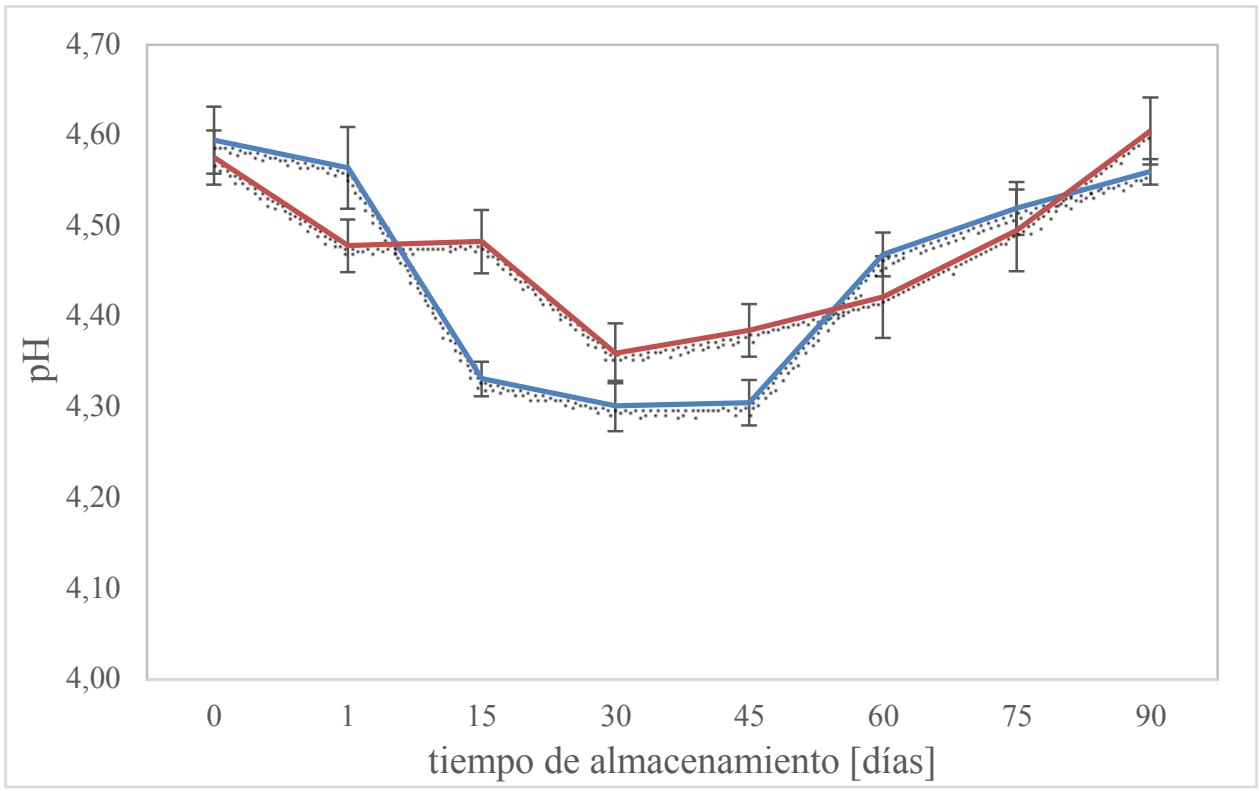

Figura 3.20 Gráficos de $\mathrm{pH}$ vs tiempo de almacenamiento para los quesos con y $\sin$ homogeneizado. $\square$ Queso sin homogeneizar $\square$ Queso homogeneizado

La adición de los distintos tipos de fibras y la sal, no mostraron diferencias significativas $(\mathrm{p}>0,05)$ con respecto a los valores de $\mathrm{pH}$. Esto podría interpretarse, en el caso de la adición de sal, considerando que el porcentaje de minerales propios del producto es de $1.00 \pm 0.17 \% \mathrm{p} / \mathrm{p}$ y solo se agregó un $0,3 \%$ de sal, lo cual parece no haber sido suficiente para detectar diferencias en los valores de $\mathrm{pH}$ como consecuencia de la adición de sal.

\subsubsection{Cuantificación del suero liberado}

La liberación de suero en los quesos depende de la composición de la leche, la firmeza del gel formado y las condiciones del proceso (Mateo y col., 2009). Después de que el gel se ha formado, las micelas de caseína todavía tienen muchos sitios reactivos en su superficie y, por tanto, se pueden formar más enlaces entre ellas. La formación de enlaces nuevos conduce a un ensamblaje más compacto de las micelas y a la expulsión de suero de leche a partir del gel (Lodaite y col., 2000). En general, el aumento del contenido de materia grasa y proteina, como es el caso de los quesos elaborados en este trabajo con leche de oveja, aumenta la firmeza de los geles y disminuye la liberación de exudado (Mateo y col., 2009).

En la Tabla 3.6 se presentan los resultados obtenidos para la liberación del suero durante el almacenamiento. El analisis estadístico de los datos recolectados reveló que la liberación de suero fue influenciada significativamente $(\mathrm{p} \leq 0,05)$ por el tiempo de almacenamiento, la adición de las fibras y la adición de sal. El proceso de 

homogeneización no afecto a la liberación de suero. Con respecto al tiempo, se puede observar en la Figura 3.21, que la liberación de suero aumentó significativamente ( $\mathrm{p} \leq$ 0,05). Al igual que en la evaluación del $\mathrm{pH}$, que no se hallaron diferencias significativas entre los porcentajes de sinéresis de los quesos recién elaborados y los quesos con un día de almacenamiento congelado, por lo tanto el proceso de congelamiento utilizado no introdujo modificaciones en la calidad de los quesos y las variaciones encontradas se deben únicamente al tiempo de almacenamiento.

En cuanto a la adición de las fibras, no hubo diferencias significativas entre los QSF, QFB y QFT pero exibieron mayor liberación de suero que los QFI y QFP, en orden descendente respectivamente. Por lo tanto, la adición de inulina y psyllium disminuyeron la liberación de suero en los quesos durante su almacenamiento. Este comportamiento concuerda con las características fisicoquímicas de las fibras que ya se mencionaron anteriormente.

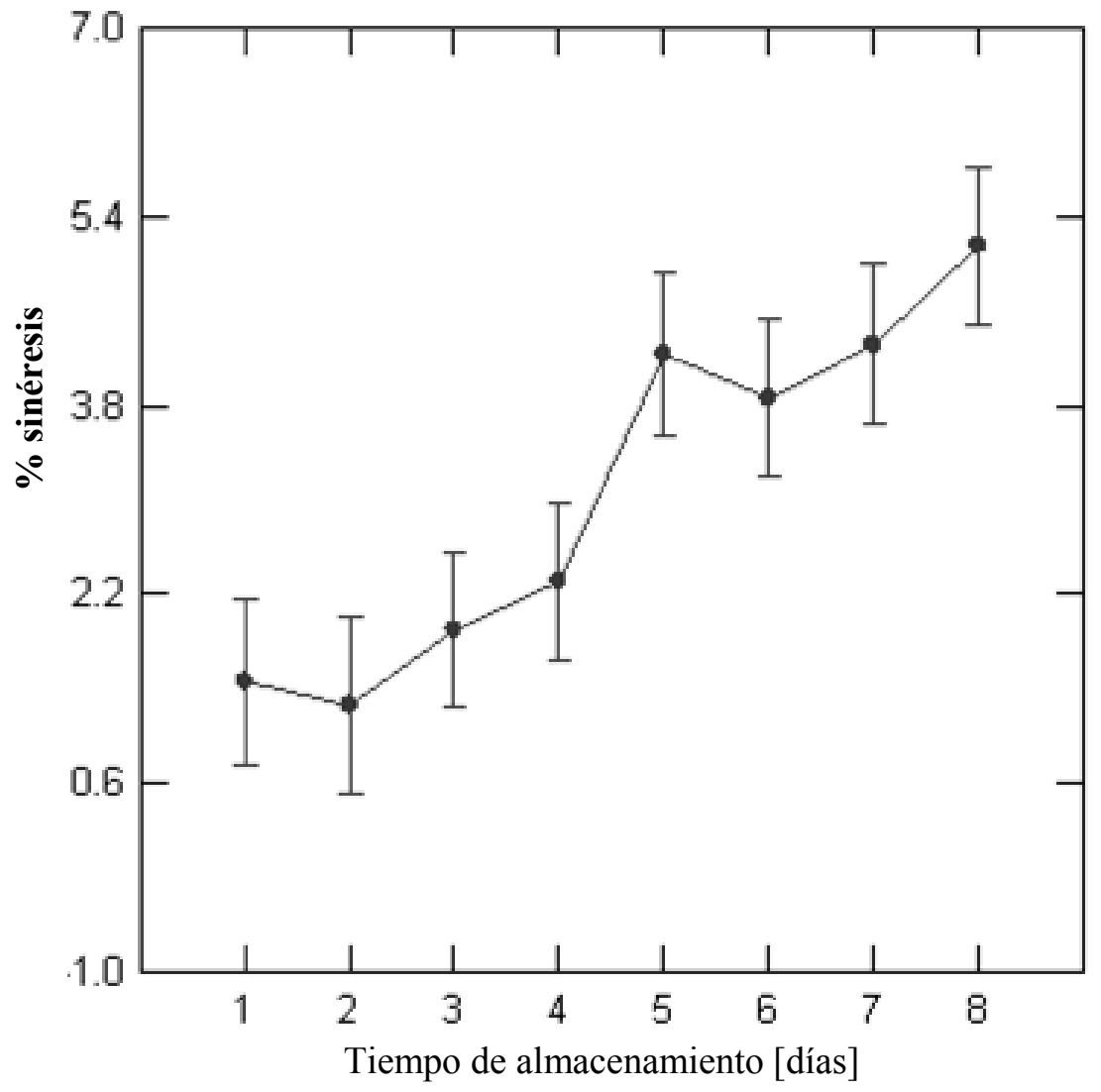

Figura 3.21 Efecto del tiempo de almacenamiento en la liberación de suero de los quesos elaborados.

Otro de los factores que influyó en la liberación de suero fue la incorporación de sal, porque afecta directamente el grado de hidratación o agregación de las caseínas, que en a su vez, afecta la capacidad de hidratación de la matriz del producto y su tendencia a 
la sinéresis. En este trabajo se observó que la adición de sal ocasionó la disminución significativa $(\mathrm{p} \leq 0,05)$ de la liberación de suero. Esto puede explicarse no solo teniendo en cuenta la interacción ión-dipolo, sino también, por la capacidad del cloruro de sodio de incrementar de tamaño de las caseínas provocando la adsorción y absorción de humedad por la matriz de proteica, disminuyendo la sinéresis (Rowney y col., 2004). De todas maneras, puede considerarse en líneas generales, que los niveles de liberación de suero durante el almacenamiento no superaron los valores aceptados para su comercialización.

Tabla 3.6 Liberación de suero [\% Sinéresis] promedio, para todos los quesos durante el almacenamiento. SHSS: Queso sin homogeneizar sin sal; SHCS: Queso sin homogeneizar con sal; HSS: Queso homogeneizado sin sal; HCS: Queso homogeneizado con sal. SF: quesos sin fibra; B: quesos con fibra de bambú; T: quesos con fibra de trigo; I: quesos con inulina; P: quesos con psyllium. Desvío estándar máximo: 1.3\%

\begin{tabular}{|c|c|c|c|c|c|c|c|c|}
\hline & & & & po de & acenan & ito [día & & \\
\hline & 0 & 1 & 15 & 30 & 45 & 60 & 75 & 90 \\
\hline SHSS & & & & & & & & \\
\hline $\mathrm{SF}$ & 0.34 & $*$ & $*$ & $*$ & * & 2.01 & 5.76 & 7.01 \\
\hline B & * & $*$ & 2.20 & $*$ & 12.71 & 11.05 & 13.19 & 14.93 \\
\hline $\mathrm{T}$ & * & * & 0.56 & * & 10.71 & 1.90 & 14.47 & 10.35 \\
\hline I & 0.35 & $*$ & $*$ & $*$ & $*$ & * & 10.48 & 3.33 \\
\hline $\mathrm{P}$ & $*$ & $*$ & $*$ & $*$ & $*$ & $*$ & $*$ & $*$ \\
\hline SHCs & & & & & & & & \\
\hline $\mathrm{SF}$ & 4.55 & 1.87 & 0.38 & 1.30 & 1.76 & 6.48 & 1.32 & 5.31 \\
\hline B & 0.26 & 0.26 & 0.08 & 2.25 & 1.29 & 4.54 & 1.54 & 6.89 \\
\hline $\mathrm{T}$ & 3.32 & 0.36 & 0.57 & 2.17 & 2.05 & 0.63 & 0.57 & 4.34 \\
\hline I & 1.14 & 2.08 & 0.26 & 1.28 & 0.69 & 6.56 & 0.66 & 3.71 \\
\hline $\mathrm{P}$ & $*$ & $*$ & $*$ & $*$ & $*$ & $*$ & $*$ & $*$ \\
\hline HSS & & & & & & & & \\
\hline $\mathrm{SF}$ & 1.03 & 1.74 & 4.41 & 3.11 & 4.98 & 9.25 & 7.17 & 6.90 \\
\hline B & $*$ & $*$ & 3.62 & 4.33 & 7.27 & 9.48 & 11.77 & 7.93 \\
\hline $\mathrm{T}$ & 1.00 & 4.66 & 9.02 & 10.38 & 3.78 & 9.30 & 11.77 & 11.73 \\
\hline I & 0.29 & 0.20 & 1.65 & 5.53 & 4.10 & * & 8.33 & 5.54 \\
\hline $\mathrm{P}$ & $*$ & $*$ & 2.57 & $*$ & $*$ & $*$ & 0.04 & $*$ \\
\hline HCS & & & & & & & & \\
\hline $\mathrm{SF}$ & $*$ & 0.58 & 0.28 & 0.49 & 1.53 & 0.43 & 1.24 & 1.71 \\
\hline B & 0.23 & 1.33 & 0.58 & 0.32 & 2.55 & 2.35 & 5.18 & 10.65 \\
\hline $\mathrm{T}$ & 0.25 & 0.31 & 0.45 & 0.68 & 2.09 & 1.37 & 3.71 & 1.33 \\
\hline I & 0.42 & $*$ & 0.17 & 0.11 & 1.46 & 1.86 & 0.01 & 2.10 \\
\hline $\mathrm{P}$ & $*$ & $*$ & 0.03 & 0.02 & 0.08 & 0.03 & 0.01 & 0.02 \\
\hline
\end{tabular}

*No presentó liberación de suero 


\subsubsection{Estudio de la microestructura luego del almacenamiento congelado}

La microestructura es una de las características más importante del queso que determina la textura de un tipo de queso (Joshi y col., 2004) y por consiguiente las propiedades funcionales están asociadas con las propiedades reológicas del queso obtenido (Gunasekaran y Ak, 2003; Montesinos-Herrero y col., 2006; Kuo y Gunasekaran, 2009). La microestructura de los quesos a 90 días de almacenamiento congelado (Figura 3.22) presentó una matriz proteica más laxa y abierta que la observada en los quesos recién elaborados (Figura 3.4) con mayores espacios ocupados por suero y/o aire entre los cúmulos de la red proteica. Esta configuración es debida a la formación de los cristales de hielo durante la congelación que interfiere con la red proteica en diferente medida dependiendo de si los cristales formados son pequeños como los generados en una congelación rápida (mínima interferencia con la red proteica) o si los cristales son grandes como los producidos en una congelación lenta (mayor modificación de la red proteica) como explicaron Graiver y col., (2004) en su trabajo realizado con queso mozzarella congelado. Sin embargo, no se observó una alteración estructural importante o muy extendida que pueda disminuir la calidad de los quesos luego del almacenamiento congelado. Estos resultados concuerdan con los descriptos por Graiver y col. (2004), Ribero y col., (2009) y Kuo y Gunasekaran, (2009) que estudiaron la microestructura de quesos Mozzarella con distintos procesos y condiciones de humedad y maduración luego del almacenamiento congelado.

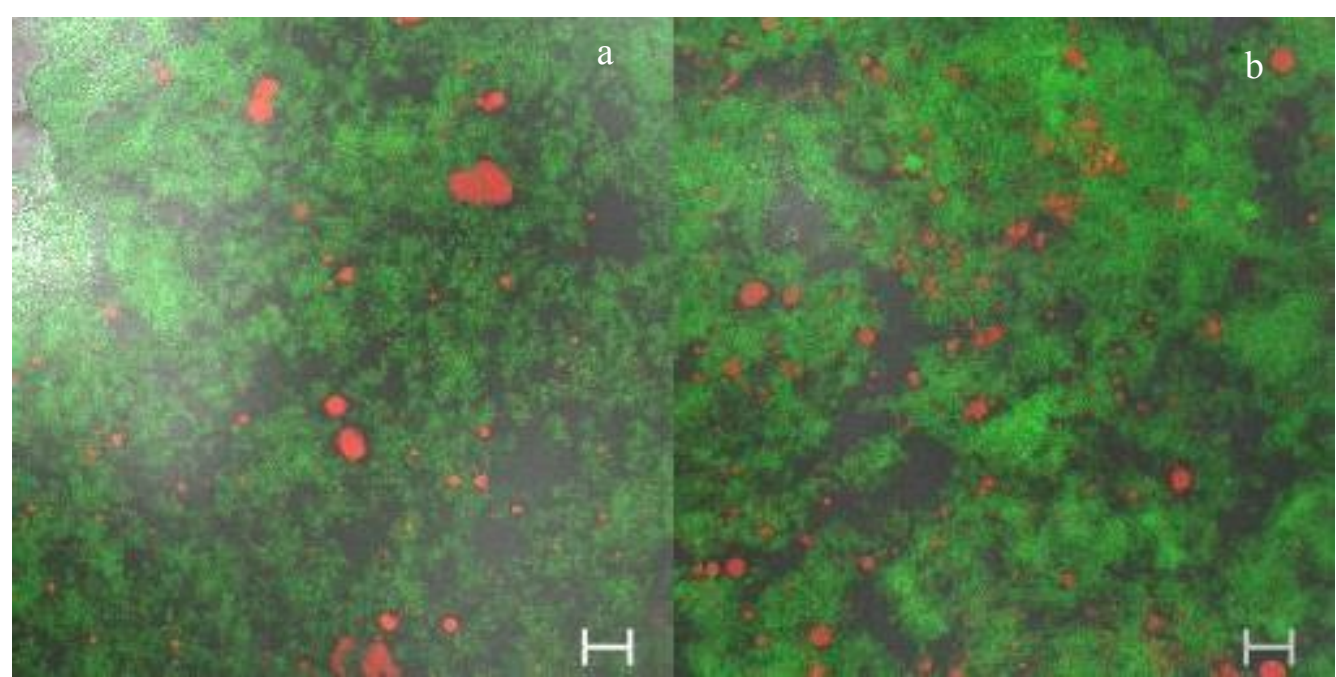

Figura 3.22 Queso sin fibra a- sin homogeneizar sin sal y b- homogeneizado sin sal a 90 días de almacenamiento congelado. Las barras de escala corresponden a $10 \mu \mathrm{m}$. 


\subsubsection{Evaluación instrumental de la textura}

En la Tabla 3.7 se pueden observar los valores obtenidos para el umbral de fluencia en función del tiempo de almacenamiento congelado para los distintos tipos de quesos analizados: con y sin homogeneizar, con y sin sal, con y sin fibras de diferente origen. Los resultados del análisis estadístico de los datos indican que la textura cambia significativamente con respecto a la adición de la sal y las distintas fibras, el proceso de homogeneizado y el tiempo. Con respecto a la adición de sal y al proceso de homogeneizado, el comportamiento durante el almacenamiento congelado, fue igual al observado para los quesos recién elaborados, expuesto en la sección 3.1.8.2. En cuanto a las diferentes fibras adicionadas, surgieron algunas diferencias en los resultados obtenidos con respecto a los quesos recién elaborados. Se observó que los quesos sin fibra y con inulina no mostraron diferencias significativas durante el almacenamiento congelado, a diferencia de los quesos recién elaborados. Sin embargo, al igual que para los quesos recién elaborados, tampoco presentaron diferencias entre sí, los quesos con fibra de trigo y los quesos con fibra de bambú. Asimismo, los quesos adicionados con psyllium exhibieron los valores más elevados del umbral de fluencia durante el almacenamiento congelado.

Con respecto al tiempo de almacenamiento, se percibieron fluctuaciones en el umbral de fluencia de los quesos durante el periodo estudiado. En particular, se observaron disminuciones significativas a los 15, 45 y 75 días de almacenamiento congelado. En contraste, no hubo diferencias significativas en el umbral de fluencia, entre los quesos recién elaborados y los quesos con 60 y 90 días de almacenamiento congelado (Figura 3.23). Estas fluctuaciones pueden explicarse teniendo en cuenta que la red proteica es una estructura que puede sufrir pérdida de humedad, escasa o limitada proteólisis durante el tiempo de almacenamiento congelado y reordenamiento luego de la descongelación antes de la medición de las propiedades mecánicas. La creación y remoción de los cristales de hielo en la estructura del queso sumada a una pequeña proteólisis de las caseínas puede tener un pequeño pero mesurable impacto en la textura del queso luego del almacenamiento congelado, como sugirieron Van Akken y col. (2005) quienes analizaron el efecto del almacenamiento congelado en las propiedades reológicas y la proteólisis de quesos blandos de leche de cabra observando también fluctuaciones en los parámetros de textura y concluyendo aun así, que se recomienda la 
aplicación del almacenamiento congelado como método de conservación para sus quesos de leche de cabra.

Tabla 3.7 Tabla de fuerza de compresión, en el tiempo de almacenamiento, para los quesos con y sin fibra en los diferentes procesos de elaboración. SHSS: Sin homogeneizar sin sal, SHCS: Sin homogeneizar con sal, HSS: Homogeneizado sin sal, HCS: Homogeneizado con sal. SF: quesos sin fibra; B: quesos con fibra de bambú; T: quesos con fibra de trigo; I: quesos con inulina; P: quesos con psyllium. Desvío estándar máximo: $1.1 \mathrm{~N}$

Tiempo de almacenamiento (días)

\begin{tabular}{|c|c|c|c|c|c|c|c|c|}
\hline & 0 & 1 & 15 & 30 & 45 & 60 & 75 & 90 \\
\hline \multicolumn{9}{|l|}{ SHSS } \\
\hline $\mathrm{SF}$ & 2.2 & 2.3 & 0.9 & 0.7 & 0.5 & 1.4 & 1.3 & 2.2 \\
\hline B & 2.4 & 3.8 & 1.6 & 1.3 & 1.3 & 3.4 & 2.2 & 2.8 \\
\hline $\mathrm{T}$ & 2.7 & 3.4 & 0.9 & 1.2 & 1.0 & 1.3 & 1.7 & 2.8 \\
\hline I & 1.8 & 3.8 & 1.1 & 0.9 & 0.9 & 2.1 & 2.3 & 2.2 \\
\hline $\mathrm{P}$ & 3.5 & 6.2 & 2.4 & 2.5 & 2.0 & 1.7 & 4.5 & 4.9 \\
\hline \multicolumn{9}{|l|}{ SHCS } \\
\hline SF & 3.3 & 4.8 & 3.3 & 2.2 & 3.9 & 5.5 & 2.5 & 3.5 \\
\hline B & 3.6 & 6.4 & 5.2 & 2.8 & 7.0 & 6.5 & 4.5 & 5 \\
\hline $\mathrm{T}$ & 4.3 & 6.4 & 4.9 & 2.6 & 6.1 & 7.9 & 5 & 6.5 \\
\hline I & 2.4 & 5.2 & 3.2 & 2.3 & 4.7 & 3.0 & 2.3 & 4.9 \\
\hline $\mathrm{P}$ & 6.8 & 10.7 & 8.7 & 7.3 & 11.3 & 8.0 & 7.0 & 7.9 \\
\hline \multicolumn{9}{|l|}{ HSS } \\
\hline $\mathrm{SF}$ & 3.8 & 2.2 & 1.4 & 1.4 & 0.7 & 0.7 & 0.6 & 1.3 \\
\hline B & 3.9 & 1.5 & 1.8 & 2.5 & 1.2 & 1.1 & 1.6 & 1.8 \\
\hline $\mathrm{T}$ & 7.3 & 4.0 & 2.1 & 1.6 & 1.0 & 0.9 & 1.5 & 1.7 \\
\hline I & 2.5 & 2.0 & 2.1 & 1.7 & 0.9 & 1.2 & 0.9 & 1.1 \\
\hline $\mathrm{P}$ & 8.0 & 4.1 & 4.3 & 5.9 & 3.0 & 4.1 & 3.4 & 5.1 \\
\hline \multicolumn{9}{|l|}{ HCS } \\
\hline $\mathrm{SF}$ & 2.9 & 2.1 & 1.8 & 1.8 & 3.6 & 1.8 & 1.3 & 2.4 \\
\hline B & 3.7 & 2.4 & 2.4 & 2.5 & 6.1 & 2.2 & 1.7 & 2.7 \\
\hline $\mathrm{T}$ & 5.2 & 3.1 & 2.6 & 2.5 & 4.9 & 3.2 & 2.7 & 2.1 \\
\hline I & 3.5 & 3.5 & 1.5 & 1.8 & 5.5 & 1.3 & 1.6 & 1.1 \\
\hline $\mathrm{P}$ & 9.5 & 4.8 & 5.7 & 4.6 & 8.7 & 5.3 & 4.8 & 6.2 \\
\hline
\end{tabular}




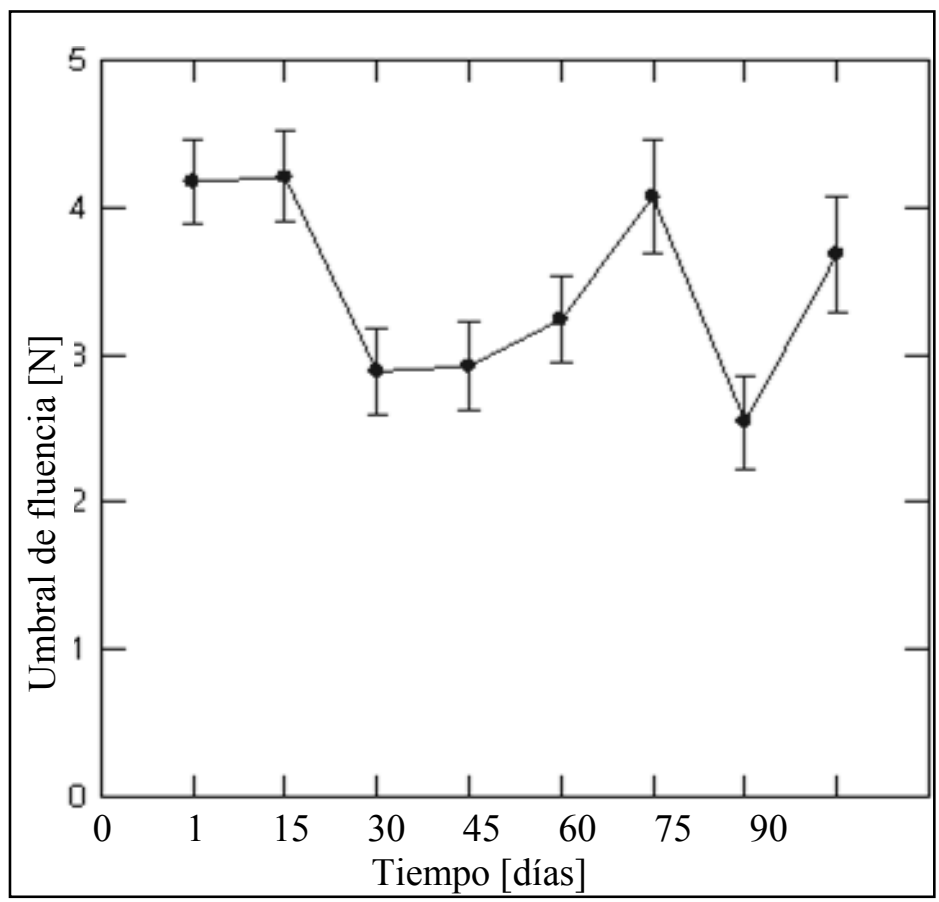

Figura 3.23 Variación del umbral de fluencia con el tiempo de almacenamiento congelado de acuerdo al análisis estadístico utilizado.

Por último, cabe mencionar que mediante el análisis estadístico de los resultados obtenidos, se observaron interacciones dobles significativas: sal x homogeneizado, tiempo x homogeneizado, tiempo x sal y fibra $\mathrm{x}$ sal, sin embargo la interacción cuádruple, no fue significativa.

\subsubsection{Determinación de la estabilidad de los lípidos durante el almacenamiento}

Como ya se mencionó en el capítulo 2 de este trabajo de tesis, la oxidación de lípidos es un tipo de deterioro que puede afectar la calidad y la aceptabilidad de los productos lácteos que son almacenados en condiciones de refrigeración o congelación durante largos periodos de tiempo y que contienen grandes proporciones de agua $\mathrm{y}$ materia grasa. Con el objetivo de valorar la posibilidad de la preservación por congelación tradicional de los quesos funcionales desarrollados en este trabajo de tesis, se estudió si se producía este tipo de alteración de la materia grasa en los quesos que se almacenaron congelados en oscuridad, en envases plásticos que los contienen para simular las condiciones de comercialización que se realizan hoy en día.

Los niveles de MDA obtenidos durante el tiempo de almacenamiento congelado variaron en promedio, entre 0.32 y $0.75 \mathrm{mg} \mathrm{MDA} / \mathrm{kg}$ queso (Figura 3.24). Estos valores fueron menores a los hallados por Okpala y col. (2010) que estudiaron queso fresco de 
leche de vaca en almacenamiento refrigerado. Sin embargo, estos valores son mayores a los encontrados en la literatura para otros tipos de quesos, por ejemplo para queso Cheddar (Seisa y col, 2004; De Wit y col, 2005) y quesos procesados (Vercelino Alves y col., 2007). Según Park (2001), que estudió dos tipos de quesos blandos, tres tipos de quesos duros de leche de cabra y queso Cheddar de leche de vaca, los quesos blandos presentan mayores niveles de MDA que los duros durante el almacenamiento. Este investigador también observó que el queso Chedar de leche de vaca presentaba mayores valores del número de TBA que los manufacturados con leche de cabra. Los quesos procesados si bien tienen alta humedad, presentan numerosos aditivos en sus formulaciones que pueden ejercer un efecto antioxidante y disminuir los niveles de MDA en el almacenamiento.

Mediante el análisis estadístico de los datos obtenidos, se observó una variación significativa $(\mathrm{p} \leq 0.05)$ en el número de TBA durante el tiempo de almacenamiento de todos los quesos de leche de oveja estudiados como se puede observar en la Figura 3.24. Se produjo un aumento de la oxidación lipídica hasta los 45 días de almacenamiento, disminuyendo a los 90 días. Esto puede atribuirse por un lado, a que la oxidación de lípidos genera mezclas complejas de productos primarios y secundarios, los cuales se van descomponiendo en una diversidad de compuestos de alto y bajo peso molecular que pueden no reaccionar con el TBA (Frankel, 2005) y por otro lado, a que los productos secundarios de oxidación pueden reaccionar con otros componentes de la matriz del alimento tales como las proteínas (Bozkurt, 2006) con su consecuente disminución.

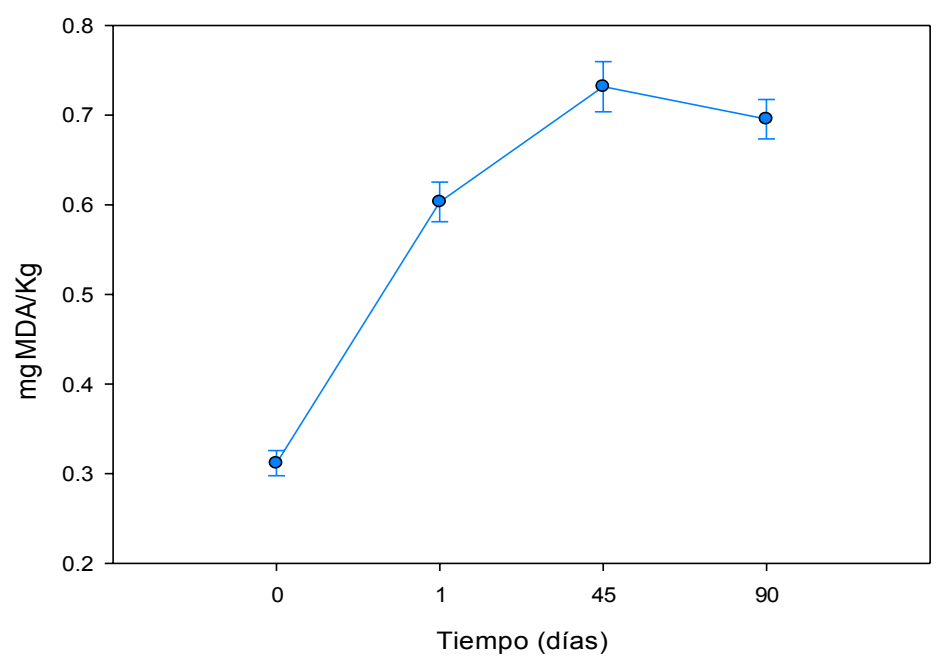

Figura 3.24 Evolución del $\mathrm{N}^{\circ} \mathrm{TBA}(\mathrm{mg} \mathrm{MDA} / \mathrm{Kg}$ ) durante el tiempo de almacenamiento para todos los quesos estudiados. 
Además, el análisis estadístico también reveló que la adición de sal no modifico significativamente los niveles hallados de MDA. Sin embargo, se produjo un aumento de la oxidación lipídica en los quesos homogeneizados, durante el almacenamiento (Figura 3.25). Este hallazgo puede explicarse, considerando que el proceso de homogeneización podría causar la elevación de los niveles de TBARS ya que favorece la lipolisis, liberando ácidos grasos libres susceptibles de ser oxidados en una reacción posterior, debido a que los ácidos grasos libres se oxidan más fácilmente que los esterificados (Park, 2001). La concentración de sal utilizada no afectó significativamente al $\mathrm{N}^{\circ}$ de TBA.

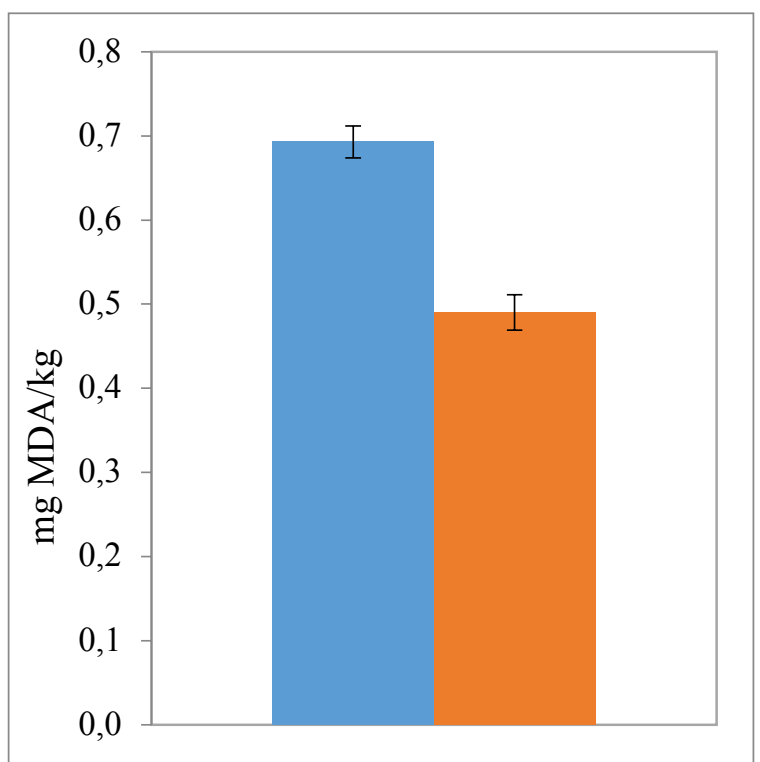

Figura 3.25 Variación del $\mathrm{N}^{\circ} \mathrm{TBA}(\mathrm{mg} \mathrm{MDA} / \mathrm{Kg}$ ) con respecto a la incorporación del proceso de homogeneización en la elaboración de los quesos.

Quesos homogeneizados $\square$ Quesos sin homogeneizar

Con respecto a la adición de fibras se observaron diferencias significativas en el número de TBA con respecto al tipo de fibra agregada. Los quesos con inulina presentaron los menores niveles de MDA y no se diferenciaron significativamente $(\mathrm{p}>0.05)$ con los quesos sin fibra (Figura 3.26). Esto puede atribuirse a la capacidad antioxidante de la inulina que ha sido comprobada recientemente (Petkova y col. 2015; Mudannayake y col. 2015). La adición de fibras de trigo, bambú y psyllium elevó moderadamente los niveles de MDA en los quesos que las contenían. Esto puede explicarse teniendo en cuenta la composición química de estas fibras. Estas tres fibras contienen diferentes proporciones de lignina, que es un polifenol. Es conocida la actividad antioxidante de estas sustancias y también ha sido asociada a la fibra dietaria 
(Saura-Calixto, 1998; Pérez-Jiménez y col., 2009; Martínez-Tome y col, 2004; Chongtham y col, 2011; Talukder y col., 2016). Sin embrago, también se sabe que bajo ciertas condiciones, los antioxidantes fenólicos son menos efectivos y tienen tendencia a actuar como "chain-carriers" (transportadores de electrones) generando nuevos radicales libres y transformándose en agentes prooxidantes (Frankel, 2005).

Por otra parte, en la literatura científica se encuentran diversos trabajos en los cuales se emplearon diferentes estrategias como el uso de atmosferas modificadas (Charles y col., 2006; Kirkin y col., 2013; Fletouris y col., 2015), películas de distintas composiciones químicas (Mortensen y col., 2002; Vercelino Alves y col., 2007; Ünalan y col., 2013) y otras (Pettersen y col., 2005), como para reducir la oxidación lipídica durante el almacenamiento de quesos. En este trabajo de tesis, la utilización de una película de menor permeabilidad al oxígeno sellada al vacío, fue un proceso adecuado para disminuir los niveles de MDA con respecto a los quesos envasados con plástico de alta permeabilidad al oxígeno, como se puede observar en la Figura 3.27.

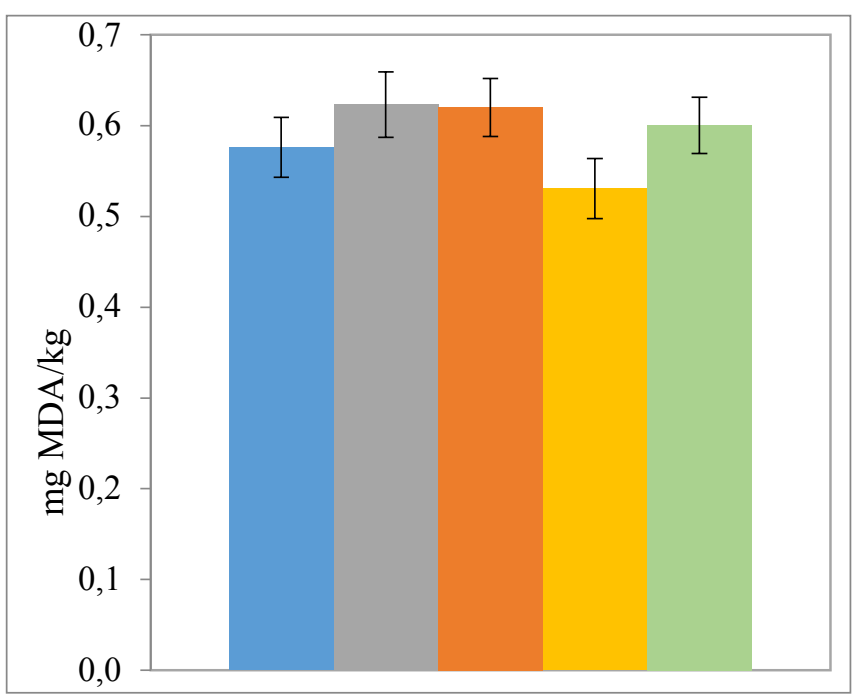

Figura 3.26 Variación del $\mathrm{N}^{\circ}$ de TBA (mg MDA/Kg) con la adición de fibra dietaria de distintos orígenes durante el almacenamiento congelado. Queso sin fibra

Queso con fibra de bambú Queso con fibra de trigo Queso con inulina

Queso con fibra de Psyllium. Las medias con las mismas letras no difieren significativamente entre ellas $(\mathrm{p}<0.05)$.

Estos resultados pueden comprenderse teniendo en cuenta que el oxígeno es uno de los factores que promueven la autooxidación de los ácidos grasos libres poliinsaturados que forman parte de la fracción lipídica de los productos lácteos (O’Connor y O’Brien, 2006). Con el empleo de una película de menor permeabilidad al oxígeno disminuyó su entrada al interior del envase reduciendo la posibilidad de la 
oxidación lipídica que es la causante de la aparición de sabores desagradables para el consumidor y la disminución de componentes nutritivos del alimento.

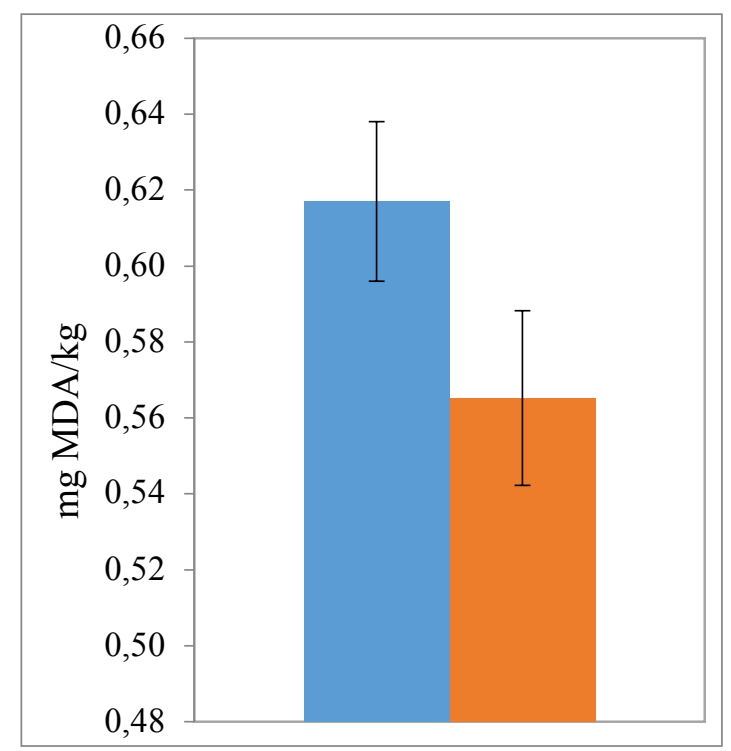

Figura 3.27 Variación del № de TBA (mg MDA/Kg) con respecto a la permeabilidad al oxígeno de las películas utilizadas para envasar los quesos durante el almacenamiento congelado. $\square$ Polietileno, $\square$ BK1.

\subsubsection{Evaluación sensorial de aceptabilidad}

En la Figura 3.28 se pueden observar los puntajes obtenidos para el ensayo aceptabilidad de los quesos elaborados luego de 90 días de almacenamiento congelado. El análisis estadístico de los datos reveló las mismas tendencias halladas en el análisis sensorial de los quesos recién preparados.

La aceptabilidad, el color, la textura y la untabilidad de los quesos almacenados solo se modificaron significativamente con la adición del psyllium. Los puntajes obtenidos para la untabilidad y la textura se elevaron significativamente con el proceso de homogeneizado y el sabor no fue modificado ni por la adición de las fibras, ni por el proceso de homogeneizado ni por la adición de sal.

Con respecto al tiempo de almacenamiento, no se observaron diferencias significativas $(\mathrm{p}>0.05)$ en los puntajes obtenidos entre los quesos recién elaborados y los quesos luego del almacenamiento congelado durante 90 días. Este resultado nos permite concluir que el almacenamiento congelado fue una alternativa válida para conservar este tipo de quesos. 


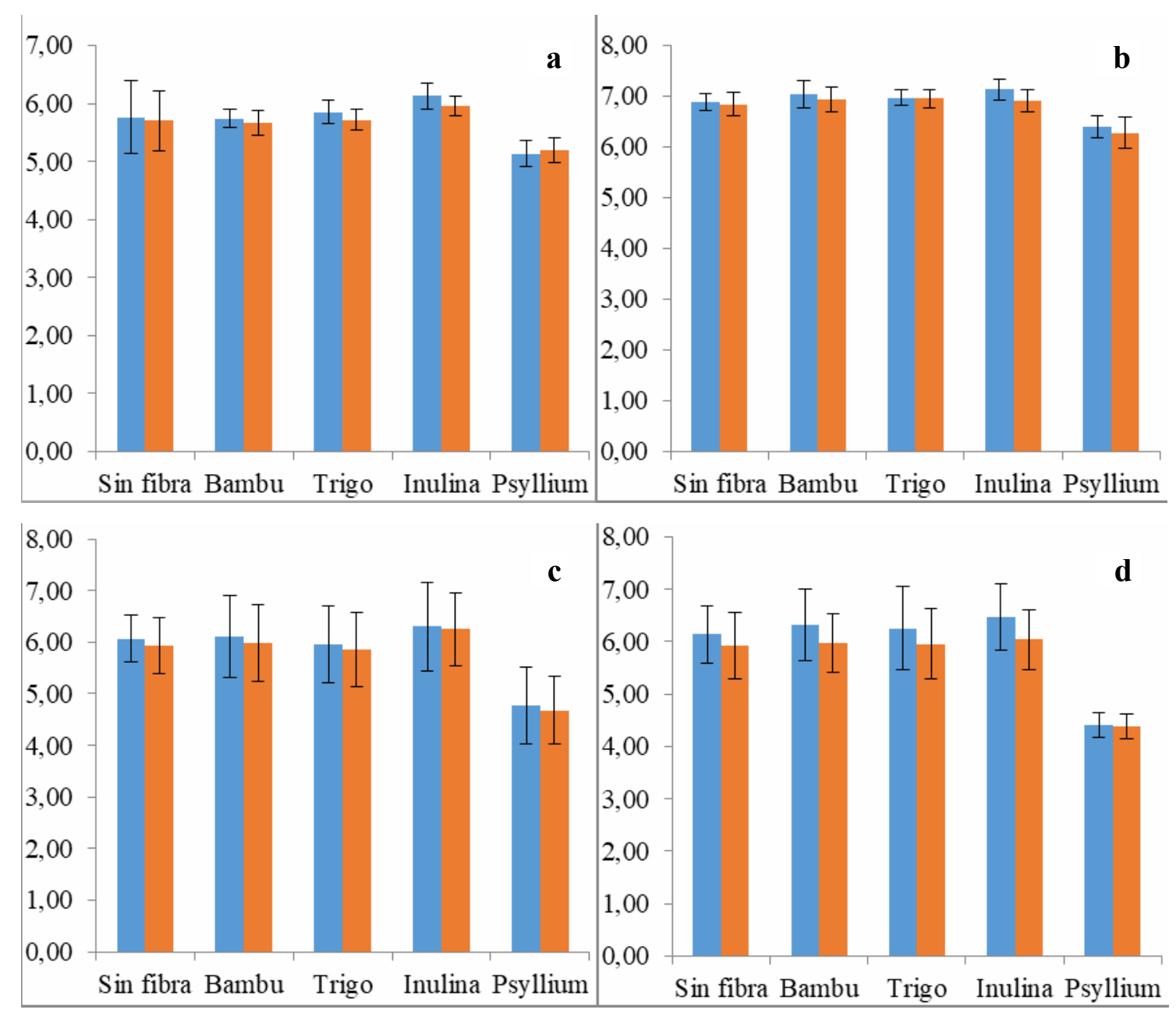

Figura 3.28 Puntajes obtenidos en el análisis sensorial durante el almacenamiento congelado ( 0 día y 90 días) de los quesos con y sin fibras, para los siguientes atributos: a- Aceptabilidad, b- Color, c- Textura, d-Untabilidad. 


\section{CAPÍTULO 4}

\section{CONCLUSIONES}




\section{CONCLUSIONES}

En este trabajo de tesis se estudió en primer lugar, las propiedades fisicoquímicas y sensoriales de los quesos funcionales recién elaborados y en segundo lugar, el comportamiento de los quesos funcionales durante su almacenamiento congelado.

De la evaluación de los quesos funcionales recién elaborados pueden destacarse los siguientes hechos:

El rendimiento quesero obtenido en el trabajo fue elevado, con lo cual, se confirma que la leche de oveja es más rentable para la elaboración de queso por presentar mayor cantidad de materia grasa y proteína en su composición.

Según la composición centesimal obtenida para los quesos desarrollados en este trabajo, podemos clasificarlos como quesos de pasta muy blanda semimagros, según lo establecido en el Código Alimentario Argentino. El agregado de fibra dietaria de distintos orígenes a los quesos, solo aumenta el contenido de hidratos de carbono, sin aportar calorías al producto. El contenido de sodio hallado está dentro los valores que presentan los quesos del mismo tipo que se comercializan en nuestro país. El contenido de calcio de los quesos con $0,3 \%$ de sal adicionada fue mayor que los quesos sin sal adicionada, lo que puede ser explicado considerando las propiedades funcionales de las caseínas. El perfil de ácidos grasos obtenido para los quesos elaborados en este trabajo de tesis es muy saludable ya que presenta varios ácidos grasos considerados como saludables, el complejo CLA y ácidos omega-3. Además, los valores de las relaciones insaturados/saturados y n-6/n-3 que utilizan los nutricionistas para evaluar el riesgo de padecer alguna de las enfermedades no transmisibles, están también, dentro del rango saludable.

Las imágenes obtenidas por microscopía láser confocal de los quesos elaborados concuerdan con las características de un gel ácido en donde la matriz proteica se observa como una red de partículas gruesas unidas en grupos, cadenas y cordones. También se visualizan los glóbulos de grasa ubicados en los poros de la red de caseína. Además, se pueden ver en la red poros pequeños en negro, que están ocupados por la fase acuosa. En los quesos a los cuales se ha añadido fibra dietaria, se observan las 
partículas de fibra como estructuras no teñidas, salvo en el caso de los quesos con inulina, que no se pueden ver porque la fibra es soluble. Se pudo precisar que no se observaron diferencias microestructurales entre los quesos con y sin sal. En contraste, en los quesos homogeneizados se pudo observar que los glóbulos de grasa tienen un tamaño menor que los hallados en los quesos no homogeneizados.

Para estudiar las propiedades mecánicas de los quesos elaborados se llevaron a cabo ensayos a pequeñas y grandes deformaciones. En el primer caso, a partir de los resultados obtenidos se pudo identificar que los quesos elaborados tienen un comportamiento viscoelástico de tipo gel débil. El proceso de homogeneizado introducido en la elaboración llevó a una disminución de los valores de G' y G', manteniéndose la fluidez de los quesos a través del valor de tan $\delta$. En cambio, la adición de sal elevó los valores de G' y G', Las curvas obtenidas experimentalmente se ajustaron satisfactoriamente al modelo escogido de la Ley de la Potencia y se obtuvieron los parámetros $\boldsymbol{a}, \boldsymbol{b}, \boldsymbol{c}$ y $\boldsymbol{d}$ que caracterizan el comportamiento reológico. Mediante análisis estadístico se evaluó la variación en los valores de estos coeficientes con respecto a la adición de sal, el proceso de homogeneización y la adición de fibras dietarias de distinto origen y se manifestaron las mismas tendencias que las observadas directamente de las curvas experimentales. En el caso de los ensayos a grandes deformaciones, el umbral de fluencia fue modificado por los tres factores estudiados. Se obtuvieron los mismos resultados con la adición de sal y con la incorporación del proceso de homogeneizado, que en el ensayo a bajas deformaciones. La adición de las distintas fibras también modificó el umbral de fluencia, pero de una forma diferente que en el ensayo a bajas deformaciones, respecto de sus propiedades fisicoquímicas.

En la evaluación sensorial, el proceso de homogeneización realizado y la adición de sal no causaron diferencias significativas ni en la aceptabilidad ni en el color de los quesos elaborados. Solamente, la adición de psyllium mostró una diferencia significativa en relación a las otras fibras y al queso sin fibra, presentando puntajes menores de estos atributos, muy posiblemente debido a su tamaño de partículas y a su color. En cuanto al atributo sabor no se observaron diferencias significativas con respecto a los tres factores estudiados: homogeneización, adición de sal y agregado de diferentes fibras. La adicion de sal, además de ser baja, no se detectó por los consumidores dado que puede ser enmascarada por el sabor característico de los 
productos elaborados con leche de oveja. En relación a los atributos de textura y untabilidad, se evidenció que el proceso de homogeneización ocasionó un aumento en el puntaje de estos atributos, avalando la introducción del proceso de homogeneización en la elaboración de los quesos. En cuanto a la adición de las fibras, no hubo diferencias significativas en los puntajes de estos atributos entre los quesos sin fibra y los quesos con fibras de bambú, trigo e inulina.

De la evaluación de la calidad de los quesos funcionales durante el almacenamiento congelado se desprenden los siguientes hallazgos:

Durante el almacenamiento, el pH obtenido osciló entre 4,61 y 4,24. Se detectaron diferencias significativas en los valores de $\mathrm{pH}$ solamente con respecto al tiempo de almacenamiento y al proceso de homogeneizado. Pudo observarse una disminución hasta los 30-45 días de almacenamiento, y a partir de los 45-60 días el pH aumentó hasta el final del almacenamiento. Además, se manifestó un descenso del pH con el proceso de homogeneización aplicado.

La liberación de suero en los quesos durante el almacenamiento congelado aumentó significativamente con el tiempo pero disminuyó por la incorporación de sal. El proceso de homogeneización no modificó los valores de este parámetro. La adición de inulina y psyllium a los quesos disminuyeron significativamente la sinéresis.

La microestructura de los quesos a 90 días de almacenamiento congelado presentó una matriz proteica más laxa y abierta que la observada en los quesos recién elaborados ya que se observaron mayor cantidad de espacios ocupados por suero y/o aire entre los cúmulos de la red proteica.

El umbral de fluencia, que fue el parámetro medido para evaluar el comportamiento de la textura durante el almacenamiento congelado, exhibió variaciones con respecto todos los factores estudiados. Es así que, con respecto al tiempo, se observó una disminución significativa a los 15, 45 y 75 días almacenamiento, retornando a valores iniciales, hacia el final del periodo de preservación. Con respecto a la adición de sal y al proceso de homogeneizado, se obtuvieron los mismos resultados que para los quesos recién elaborados. En contraste y analizando la adición de fibra, se advirtió que los quesos sin fibra y con inulina no mostraron diferencias significativas en el umbral de fluencia a 
diferencia de lo ocurrido en los quesos recién elaborados.

Los niveles de MDA obtenidos en la evaluación de la estabilidad lipídica de los quesos fueron menores a los hallados por otros investigadores en quesos del mismo tipo de leche de vaca. Aun así, se produjo un aumento de la oxidación lipídica hasta los 45 días, disminuyendo luego a los 90 días de almacenamiento. El análisis estadístico también reveló que hubo un aumento de la oxidación lipídica en los quesos homogeneizados. Sin embargo, la adición de sal no modificó significativamente los niveles hallados de MDA. Con respecto a la adición de fibras se observaron diferencias significativas con respecto al tipo de fibra agregada. Los quesos con inulina presentaron los menores niveles de MDA y no se diferenciaron significativamente con los quesos sin fibra. La adición de fibras de trigo, bambú y psyllium elevó moderadamente los niveles de MDA en los quesos que las contenían.

En el análisis sensorial de los quesos, luego de finalizado el periodo de preservación por congelación, no se observaron diferencias significativas en los puntajes obtenidos entre los quesos recién elaborados y los quesos de 90 días de almacenamiento.

Estos resultados nos permiten señalar que el almacenamiento congelado es una alternativa válida para conservar quesos frescos de leche de oveja y poder comercializarlos en los meses del año en los cuales no hay producción de leche de oveja con el objeto de evitar la caída de los precios en los meses del año en los cuales hay una gran producción, teniendo en cuenta que, la leche de este origen tiene muchas características beneficiosas para la salud y es un hecho un tanto negativo que disminuya su valor de mercado por la particularidad de que se elabora con una materia prima estacional.

En síntesis, puede decirse que la adición de sal no superó los niveles de sodio presentes en los quesos que hoy en día se comercializan en nuestro país. La adición de sal también ayuda a retener el calcio en la red proteica y no alteró la microestructura de los quesos. Asimismo, elevó los valores de las propiedades mecánicas estudiadas sin necesidad de utilizar otro tipo de aditivos comúnmente hallados en los quesos que consumimos actualmente.

Desde el punto de vista de las fibras utilizadas, puede destacarse que su presencia aportó a los quesos, hidratos de carbono funcionales y saludables sin 
aumentar excesivamente el valor calórico y sin alterar su microestructura. La inulina que es totalmente soluble, disminuyó la consistencia y el umbral de fluencia de los quesos, en cambio, las fibras totalmente insolubles de trigo y bambú, los aumentaron. Los quesos con psyllium presentaron una consistencia igual al queso sin fibra, pero elevaron notoriamente el umbral de fluencia. En el análisis sensorial la inulina y las fibras de trigo y bambú no causaron diferencias significativas en el sabor, la textura, la untabilidad, el color y la aceptabilidad general de los quesos que las contenían. El psyllium, si bien disminuyó significativamente la liberación de suero, lo cual es muy positivo, tuvo mucho impacto en el color y la textura del producto, disminuyendo, por su color y tamaño de partículas, la valoración de la aceptabilidad, del color, de la textura y de la untabilidad sin modificar, no obstante, la calificación del sabor percibida por los consumidores.

La incorporación del proceso de homogeneización a nivel de la microestructura, disminuyó el tamaño de los glóbulos de grasa e hizo que la red proteica quedara más particulada. A nivel del análisis sensorial el proceso de homogeneización aumentó la aceptabilidad sensorial de los atributos de textura y untabilidad de los quesos.

Las variaciones observadas en el pH, liberación de suero, estabilidad lipídica, microestructura y textura durante el periodo de preservación por congelación no modificaron la aceptabilidad sensorial de los quesos estudiados luego de finalizado el almacenamiento.

Por todo lo anteriormente expuesto, se puede concluir finalmente que es posible elaborar quesos frescos untables de leche ovina funcionales con inulina, fibra de trigo o fibra de bambú con características muy saludables desde el punto de vista nutricional. De igual modo, la adición de $0.3 \%$ de sal, el proceso de homogeneizado y el almacenamiento congelado fueron alternativas tecnológicas adecuadas para elevar y preservar la calidad de los quesos frescos untables desarrollados. 
REFERENCIAS 


\section{REFERENCIAS}

Albenzio M, Santillo A, Avondo M, Nudda A, Chessa S, Pirisi A, Banni S. (2016). Nutritional properties of small ruminant food products and their role on human health. Small Ruminant Res 135:3-12.

Albenzio, M.; Santillo, A.; Caroprese , M.; Ruggieri , D.; Napolitano, F. y Sevi, A. (2013). Physicochemical properties of Scamorza ewe milk cheese manufactured with different probiotic cultures. Journal of Dairy Science, 96, 5, 27812791.

Alichanidis, E.; Polichroniadou, N.; Tzanetakis, N. y Vafopoulou, A. (1981). Telemè Cheese from deep-frozen curd. Journal of Dairy Science, 64, 732-739.

Alvarenga, N.B.; Ferro, S.P.; Almodôvar, A.S.; Canada, J. y Sousa, I. (2013). Shelf-life extension of cheese: frozen storage. Capítulo 6 en Handbook of cheese in health: Production, nutrition and medical sciences. Editado por Preedy, V.R.; Watson, R.R. y Patel, V.B. WageningenAcademic.com: Wageningen, Países Bajos.

Anderson, J.W.; Baird, P.; Davis, Jr R.; Ferreri, S.; Knudtson, M.; Koraym, A.; Waters, V. y Williams, C. L. (2009). Health benefits of dietary fiber. Nutrition Reviews, 67(4), 188-205.

Anderson, E. y Fireman, M. (1953) The mucilage from psyllium seed, Plantago psyllium. L.J. Biological Chemistry, 109, pp. 437-445.

Auffret, A., Ralet, M. C., Guillon, F., Barry, J. L. y Thibault, J. F. (1994). Effect of grinding and experimental conditions on the measurement of hydration properties of dietary fibers. LebensmittelWissenschaft-und-Technologie, 27, 166-172.

Augustin, M. y Sanguansri L. (2015). Micro-and Nano-encapsulation ofFunctional Ingredients in Food Products. "World Congress on Oils \& Fats and 31st Lectureship Series", Córdoba, Argentina.

Augusto, P. E. D., Cristianini M., Ibarz, A. (2012). Effect of temperature on dynamic and steady-state shear rheological properties of siriguela (Spondias purpurea L.) pulp. Journal of Food Engineering, 108, 283-289.

Appleqvist, I. A. M., Cochet-Broch, M., Poelman, A. A. M. y Day, L. (2015). Morphologies, volume fraction and viscosity of cell wall particle dispersions particle related to sensory perception. Food Hydrocolloids, 44, 198-207.

Badui Dergal, S. (2006). Capítulo 5: Enzimas (pag. 301-362). En: Química de los Alimentos. Pearson Educación: México.

Balthazar C.F., Pimentel T.C., Ferrão L.L., Almada C.N., Santillo A., Albenzio M., Mollakhalili N., Mortazavian A.M., Nascimento J.S., Silva M.C., Freitas M.Q., Sant'Ana A.S., Granato D. y Cruz A.G. (2017). Sheep Milk: Physicochemical Characteristics and Relevance for Functional Food Development. Comprehensive Reviews in Food Science and Food Safety, Vol.16. 
Balthazar, C. F.; Conte Júnior, C.A.; Moraes, J.; Costa, M.P.; Raices, R.S.L.; Franco, R.M.; Cruz, A.G. y Silva, A.C.O. (2016). Physicochemical evaluation of sheep milk yogurtsn containing different levels of inulin. J. Dairy Sci. 99:1-9

Barclay, A.W.; Petocz, P.; McMillan-Price, J.; Flood, V.M.; Prvan, T. y Mitchell, P. (2008) Glycemic index, glycemic load, and chronic disease riskea metaanalysis of observational studies. American Journal of ClinicalNutrition 87,pp. 627-637.

Barreiro Mendez, J. y Sandoval, A. (2006) Operaciones de conservación de alimentos por bajas temperaturas. Capítulo 6, Editorial Equinoccio, Venezuela

Bayod, E., Willers, E. P. y Tornberg, E. (2008). Rheological and structural characterization of tomato paste and its influence on the quality of ketchup. $L W T, 41$, 1289-1300.

Bays, H.E.; Jones, P.H.; Orringer, C.E.; Brown, W.V.; Jacobson, T.A. (2016). National Lipid Association Annual Summary of Clinical Lipidology 2016. Journal of Clinical Lipidology, 10(1), Supplement January-February, S1-S43.

Bertola, N.C.; Califano, A.N.; Bevilacqua, A.E. y Zaritzky, N.E. (1996). Textural changes and proteolysis of low-moisture mozzarella cheese frozen under various conditions. Journal Science and Technology-Lebensmittel-Wissenschaft und Technologie, 29, 470-474.

Boekenoogen, H. A. Analysis and characterization of oils, fat, and fat products; Interscience Publishers: London 1964

Bølling Johansen, S. (2010). Consumer perception and acceptance of caloriereduced dairy products. Philosophiae Doctor (PhD) Thesis. Dept. of Chemistry, Biology and Food Science Norwegian University of Life Sciences. CopyCat avd. Ski, Noruega.

Bølling Johansen, S.; Naes, T.; Øyaas, J. y Hersleth, M. (2010). Acceptance of calorie-reduced yoghurt: Effects of sensory characteristics and product information. Food Quality and Preference, 21, 13-21.

Bourne, M.C. (2002) Food Texture and Viscosity, Concept and Measurement (Second Edition). New York, Academic Press.

Bozkurt H. (2006). Utilization of natural antioxidants: green tea extract and Thymbraspicata oil in Turkish dry-fermented sausage. Meat Science 73: 442-450

Busetti, M.R. (2006a). La Calidad en la Leche de Oveja. Boletín de divulgación Técnica INTA n ${ }^{\circ}$ 90, Octubre, 205 -215.

Busetti, M.R. (2006b). Composición de la leche de oveja Pampinta en condiciones pastoriles. Boletín de divulgación Técnica INTA nº 90, Octubre, 216-229.

Brownlee, I.A. (2011) The physiological roles of dietary fibre. Food Hydrocolloids 25, pp. 238-250.

Brunner, J.R. (1965) Fundamentals of dairy chemistry Editores Webb, B.H.yJohnson, A.H. Avi Publishing Co., Westport, Conn, pp. 403-505. 
Califano, A.N. y Bevilacqua, A.E. (1999). Freezing low-moisture mozzarella cheese - changes in organic-acid content. Food Chemistry, 64, 193-198.

Cassiani D.M.; Yamul D.K.; Conforti P.A.; Perez V.A. y Lupano C.E. (2011) Structure and Funcionality of Whey Protein Concentratre-Based Products with Different Water Contents. 2011. Food Bioprocess Technol, 6, issue, pp.217-227.

Castillo M., Lucey J.A. y Payne F.A. (2006a). The effect of temperature and inoculum concentration on rheological and light scatter properties of milk coagulated by a combination of bacterial fermentation and chymosin. Cottage cheese-type gels. International Dairy Journal, 16, 131-146.

Castillo M., Lucey J.A., Wang T. y Payne F.A. (2006b). Effect of temperature and inoculum concentration on gel microstructure, permeability and syneresis kinetics. Cottage cheese-type gels. International Dairy Journal, 16, 153-163.

Cederholm, T.; Salem Jr, N. y Palmblad, J. (2013). $\omega$-3 Fatty acids in the prevention of cognitive decline in humans. Advances in Nutrition, 4, 672-676.

Cervantes, M.A., Lund, D.B. y Olson, N.F. (1983). Effects of salt concentration and freezing on Mozzarella cheese texture. Journal of Dairy Science, 66, 204-209.

Chan, J.K.C. y Wypyszyk, V. (1988) A forgotten natural dietary fiber: Psyllium Mucilloid. Cereals foods world, 33 (11), pp. 919-922.

Charles, F., J. Sanchez y N. Gontard. (2006). Absorption kinetics of oxygen and carbon dioxide scavengers as part of active modified atmosphere packaging. J. Food Eng. 72:1-7.

Chaves Viotto, W.H. y Grosso, C.R.F. (1999). Proteolysis and functional properties of mozzarella cheese as affected by refrigerated storage. Journal of Food Science, 64, 202-205.

Cho, I.J.; Lee, C. y Ha, T.Y. (2007) Hypolipidemic effect of soluble fiber isolated from seeds of Cassiatora Linn in rats fed a high-cholesterol diet. Journal of Agriculture and Food Chemistry 55, pp.1592-1596.

Chongtham, N.; Singh Bisht, M. y Haorongbam, S. (2011). Nutritional Properties of Bamboo Shoots: Potential and Prospects for Utilization as a Health Food. Comprehensive Reviews in Food Science and Food Safety, Vol.10, 153-169.

Code of Federal Regulations. Health claims (2010): fruits, vegetables, and grain products that contain fiber, particularly soluble fiber, and risk of coronary heart disease. Secc.101, 77.

Cole, L.J.N; Kluepfel, D. \& Lusena, C. V.(1959) Freezing Damage to bovine cream indicated by release of enzymes. Canadian Journal of Biochemistry and Physiology,Vol. 37, No. 7, pp. 821-827.

Cooper, C., M. Corredig y M. Alexander(2010).Investigation of the colloidal interactions at play in combined acidification and rennet of different heat-treated milks. J. Agric. Food Chem. 58:4915-4922. 
Cooper, H.R. (1987) Texture in dairy products and its sensory evaluation, en Food Texture-Intrumental and Sensory Measurement, H.R. Moskowitz, New York: Marcell Dekker Inc. pp. 217-250.

Corley, R.T \& Doan, F.J. (1940). A Study of Concentration and Freezing as a Means of Preserving Fluid Whole Milk. Food Research, 5, 369-378.

Cruz, A.G.; Faria, J.A.F.; Pollonio M.A.R.; Bolina H.M.A.; Celeghini

R.M.S. Granato D. \& Shah N.P. (2011) Cheeses with reduced sodium content: effects on functionality, public health benefits and sensory properties. Trends in Food Science \& Technology, 22, pp. 276-291.

Cruz, G.A; Cadena, R.S; Walter, E.H.M; Mortazavian, A.M; Granato, D; Faria, J.A.F \&Bollini, H.M.A (2010) Sensory analysis: Relevance for prebiotic, probiotic y symbiotic product development. Comprehensive review in food science and food safety, Vol 9

Cummings, T.J.; Mann, J.; Nishida, C. \& Vorster, H. (2009) Dietary fiber: An agreed definition. Lancet 373, pp.365-366.

Dahm, C.C.; Keogh, R.H.; Spencer, E.A.; Greenwood, D.C.; Key, T.J.; Fentiman, I.S; Shipley, M.J.; Brunner, E.J.; Cade, J.E.; Burley, V.J.; Mishra, G.; Stephen, A.M.; Kuh ,D.; White, I.R.; Luben, R.; Lentjes, M.A.H.; Khaw, K.T. y Bingham, S.A. (2010) Dietary Fiber and colorectal cancer risk: A Nested case-control Study Using Food Diaries. Journal of the National Cancer Institute 102(9), pp. 614-626.

Dalgleish, D.G. (1979). Proteolysis and aggregation of casein micelles treated with immobilized or soluble chymosin. J. Dairy Res. 46:653-661.

Day, L.; Seymoura, R.B.; Pittsa, K.F.; Konczaka, I. \& Lundin, L. (2009)Incorporation of functional ingredients into foods.Trends in Food Science \& Technology 20, pp. 388-395.

De Oliveira Hauly, M. C. \&Moscatto, J. A. (2002) Inulin and oligofructosis: a review about functional properties, prebiotic effects and importance for food industry. Semina: Ciencias Exactas e Tecnológica, Londrina, 23 (1) 10, pp. 105-118.

Dello Staffolo, M.; Bértola, N. Martino, M. \&Bevilacqua, A. (2004) Influence of dietary fiber addition on sensory and rheological properties of yogurt. International Dairy Journal, Vol. 14, pp. 263-268.

Dello Staffolo, M.; Martino, M. \&Bevilacqua, A. (2007) Texture and sensory properties of dairy desserts with dietary fibres of different sources. ActaAlimentaria, 36(3), pp. 371-361.

Dello Staffolo, M.; Martino, M.; Bevilacqua, A.; Montero, M.; Rodríguez, M.S. \& Albertengo L. (2008). Chitosan Interaction with Iron from Yoghurt Using an In Vitro Digestive Model: Comparative Study with Plant Dietary Fibers. Int. J. Mol. Sci. 12, pp. 4647-4660

Dello Staffolo, M.; Martino, M.; Bevilacqua, A.E.; Montero, M.; Rodríguez, M.S. y Albertengo, L. (2011) "Chitosan interaction with iron from yoghurt using an in 
vitro digestive model: comparative study with plant dietary fibers. International Journal of Molecular Science, 12, 4647-4660.

Dello Staffolo, M. y Pinotti, A. (2017) "Evaluación de las propiedades fisicoquímicas y sensoriales de muestras comerciales de dulce de leche como trabajo de laboratorio para alumnos de grado". Actas de Trabajos Completos del IX Congreso Argentino de Ingeniería Química, CAIQ2017, (ISSN 1850-3519).

De Wit, M.; G. Osthoff, B.C. Viljoen; A. Hugo (2005). A comparative study of lipolysis and proteolysis in Cheddar cheese and yeast-inoculated Cheddar cheeses during ripening. Enzyme and Microbial Technology 37 (2005) 606-616

Di Monaco, R.; Giancone, T.; CAVELLA, S. y MASI, P. (2008). Predicting texture attributes from microstructural, rheological and thermal properties of hazelnut spreads. Journal of Texture Studies, 39, 460-479.

Doan, F. J. y Balwind, F. B. Jr (1936) Observations on the freezing of milk and cream II. The destruction of the fat emulsion in frozen cream en fundamentals in dairy chemistry Editores: Webb, B.H y Johnson, A.H.Avi Publishing Co., Westport, Conn., pp771-813.

Doan, F.J. y Featherman, C.E. (1937). Observations on concentrated frozen milk. The Milk Dealer 27, 33-34 and 62.

Doan, F.J. y Keeney, P.G. (1965). Frozen dairy products. In Fundamentals of dairy chemistry, eds B. H. Webb \& H. Johnson. Avi. Publ., Westport, p. 215.

Elleuch, M.; Bedigian, D.; Roiseux, O.; Besbes, S.; Blecker, C. \&Attia, H. (2011) Dietary fibre and fibre-rich by-products of food processing: Characterization, technological functionality and commercial applications: A review. Food Chemistry, 124, pp. 411-421.

Englyst, H.N.; Quigley, M. E. y Hudson, G. J. (1995). Definition and measurement of dietary fiber. European Journal of Clinical Nutrition, 49 (Supl. 3), pp. S48-S62.

Eshak, E.S.; Iso, H.; Date, C.; Kikuchi, S.; Watanabe, Y.; Wada, Y.; Tamakoshi, A. y el grupo de estudio JACC (2010). Dietary fiber intake is associated with reduced risk of mortality from cardiovascular disease among Japanese men and women. Journal of Nutrition 140, pp. 1445-1453.

Everett, D.W.; Auty M.A.E. (2008). Cheese structure and current methods of analysis. International Dairy Journal, 18, 759-773.

Fennelone, M.A. y Guinee, T.P. (1999). The effect of milk fat on cheddar cheese yield and its prediction using modifications of the Van Sluke cheese yield formula. Journal of Dairy Science 82, pp. 2287-2299.

Fennema, O.R.; Powrie, W.D. y Marth, E.H. (1973) Capítulo 5: Characteristic of fluid foods and their behavior during freeze preservation en Low temperature preservation of foods and living matter. Editor Fennema, O.R. Editorial Marcel Dekker, INC, New York. 
Figura, L. O.; Teixeira, A. A. (2007). Food Physics: Physical Properties. Measurement and Applications. Springer Verlag: Leipzig, Alemania.

FIL/IDF (1982). Recombination of milk and milk products. Bulletin of the International Diary Federation, document 142. Federation Internationale Laitiere, Bruselas, Bélgica, p. 204.

Fiszman, S.M. \& Salvador, A. (1998). Effect of gelatine on the texture of yoghurt and of acid-heat-induced milk gels. Z. Lebensm Untersforsch A 208; pp.100105.

Fletouris, D. J., Govari, M. A. and Botsoglou, E. N. (2015). The influence of retail display storage on the fatty acid composition of modified atmosphere packaged GravieraAgraphon cheese. International Journal of Dairy Technology, Vol. 68 (2), 218 226.

Floury, J., Rouaud, O., Le Poullennec, M., \& Famelart, M. H. (2009) Reducing salt level in food: Part 2: modelling salt diffusion in model cheese systems with regards to their composition. LWT - Food Science and Technology, 24(10), pp. $1621-1628$.

Foegeding, E.A.; Brown, J.; Drake, M.A. \& Daubert, C.R. (2003) Sensory and mechanical aspects of cheese texture. International Dairy Journal, 13, 585-591.

Foglietta, F.; Serpe, L.; Canaparo, R.; Vivenza, N.; Riccio, G.; Imbalzano, E.; Gasco, P.; Zara, G.P. (2014). Modulation of butyrate anticancer activity by solid lipid nanoparticle delivery: an in vitro investigation on human breast cancer and leukemia cell lines. Journal of Pharmacy \& Pharmaceutical Sciences, 17, 231-47.

Fontecha, J.; Peláez, C.; Juárez, M. y Martín-Hernández, M.C. (1994). Effect of freezing and frozen storage on the physicochemical, organoleptic and microbiological characteristics of a semihard ewes milk cheese. Journal of Dairy Research, 61, 133-142.

Food and Nutrition Board, Institute of Medicine (2001) Dietary reference intakes. Proposed definition of dietary fiber. A report of the panel on the definition of dietary fiber and the standing committee on the scientific evaluation of dietary reference intakes.Washington, DC: National Academy Press.

Fox, P.F; Guinee, T.P; Cogan, T.M \& McSweeney P.L.H. (2000) Processed cheese and substitute or imitation cheese products. In: Fundamentals of cheese science. Gaithersburg, Md.: Aspen Publishers Inc. p 429-41.

Franck, A. (2002). Technological functionality of inulin and oligofructose. British Journal of Nutrition, 87, Suppl. 2, S287-S291.

Frankel, E.N. (2005). Lipid Oxidation. Second Edition. The Oily Press. Bridgwater U.K.

Friedman, H.H.; Whitney, J.E. \& Szczesniak, A.S. (1963) Thetexturometer: a new instrument for objective texture measurement. Journal of Food Science, 28: 390396. 
Galvan Romo, L. (2007) Evaluación sensorial: queso de oveja y cabra. InstitutoNacional de Tecnología Industrial (INTI).

Gibson, G.R. y Williams, C.M. (2000) Functional Foods: Concept to Product. Cambridge: Wood head Publishing, pp. 374.

Gómez Candela, C.; Bermejo López, L.M. y Kohen, V.L. (2011). Importance of a balanced omega 6/omega 3 ratio for the maintenance of health. Nutritional recommendations. Nutrición Hospitalaria, 26(2), 323-329.

Green, C.J. (2000) Fiber in enteral nutrition. South African Journal of Clinical Nutrition 13(4), 150-160.

Gresti, J., Burgaut, M., Maniongui, C., y Bezard, J. (1993). Composition of molecular species of triacylglycerols in bovine milk fat. Journal of Dairy Science, 76, $1850-1869$.

Graiver, N.G., Zaritzky, N.E. y Califano, A.N. (2004). Viscoelastic behavior of refrigerated and frozen low-moisture mozzarella cheese. Journal of Food Science, 69, 123-128.

Gruda, Z. y Postolski, J. (1986). Tecnología de la congelación de los alimentos. Editorial Acribia S.A. Zaragoza, España.

Guinee, T. P., y Fox, P. F. (2004). Salt in cheese: physical, chemical and biological aspects. Cheese chemistry (3rd ed.). Physics and Microbiology, Vol. 1 Editores: Fox, P.F.; McSweeney, P.L.H; Cogan, T.M. \&Guinee, T.P. Amsterdan, Elsevier Academic Press, 207-259.

Guinee, T.P.; Pudja, P.D. y Farkye, N.Y (1999). Capítulo 13. Fresh acid-curd cheese varieties, en Cheese: Chemistry, physics and microbiology. Vol2 Major cheese group. Editor: Fox, P.F. Editorial: Aspen publishes, Aspen, USA, pp. 363.

Gujral, H. y Sodhi, N. (2002). Back extrusion properties of wheat porridge (Dalia). Journal of Food Engineering, 52, 53-56.

Gunasekaran, S. y Ak, M.M. (2003) Capítulo 7: Cheese Texture en Cheese Rheology and Texture, Editorial CRC Press, Boca Raton, Florida, USA.

Haenlein, G.F.W. (2001) The Nutritional Value of Sheep Milk. Department of Animal \& Food Sciences University of Delaware, Newark, Delaware, USA, pp. 197171303.

Heller, K.J.; Bockelmann, W.; Schrezenmeir, J. \&DeVrese, M. (2003) Cheese and its potential as a probiotic food En Handbook of fermented functional foods.Editor: Farnworth E. R., Editorial: Boca Raton, CRC Press, pp. 203-225.

Herrmann, K. (1977) Capítulo III: Alimentos de origen animal en Alimentos congelados: Tecnología y comercialización.Editorial Acribia, Zaragoza, España, pp. 77142

Holt, C. (1992). Structure and stability of bovine casein micelles en Advances in protein chemistry. Editores: Anfinsen CB, Edsall JT, Richards FM y Eisenberg DS. Vol. 43. London, U.K.: Academic Press Inc. p. 63-151. 
Horne, D.S. (1999).Formation and structure of acidified milk gels. International Dairy Journal, 9, 261-268.

Huth, P.J.; Park, K.M. (2012). Influence of dairy product and milk fat consumption on cardiovascular disease risk: a review of the evidence. Advances in Nutrition, 3, 266-285.

Iop, S.C.F.; Silva, R.S.F. y Beleia, A.P. (1999). Formulation and evaluation of dry dessert mix containing sweetener combinations using mixture response methodology. Food Chem., 66, pp.167-171.

ISO 13320:2009(E). International standard. Particle size analysis - Laser diffraction methods. Geneva: ISO Organization.

Jiménez Colmenero F. (2007). Healthier lipid formulation approaches in meatbased functional foods. Technological options for replacement of meat fats by non-meat fats. Trends in Food Science \& Technology 18:567-578

Jensen, R. G., \& Newburg, D. S. (1995).Bovine milk lipids. En R. G.Jensen (Ed.), Handbook of milk composition. New York, USA: Academic Press.

Joshi, N.S., Muthukumarappan, K. y Dave, R.I. (2004). Effect of calcium on microstructure and meltability of part skim Mozzarella cheese. Journal of Dairy Science 87 (7), 1975-1985.

Juárez Iglesias, M. (1999). Leche y derivados lácteos (pag. 377-387). En: Tratado de Nutrición. Editado por Hernández Rodríguez, M. y Sastre Gallego, A. Ediciones Díaz de Santos: Madrid.

Kaczmarczyka, M.M.; Michael, J.; Miller, M.J. \& Freunda, G.G. (2012). The health benefits of dietary fiber: Beyond the usual suspects of type 2 diabetes mellitus, cardiovascular disease and colon cancer. Metabolism. doi:10.1016/j.metabol.2012.01.017.

Kasprzak, K.; Wendorff, W.L. y Chen, C.M. (1994). Freezing qualities of Cheddar-type cheeses containing varied percentages of fat, moisture, and salt. Journal of Dairy Science, 77, 1771-1782.

Kapoor, R. y Metzger, L.E. (2008). Process cheese scientific and technological aspects-A review. Comprehensive reviews in food science and food safety, vol 7, issue 2, pp.194-214.

Kilcast, D. (2004) Capítulo 1: Measuring consumer perceptions of texture: an overview en Texture in food Volume 2: Solid foods. Editor, David Kilcast. Editorial Boca Raton, Boston, New York, Washington, DC.

Kirkin, C., Gunes, G. and Kilic-Akyilmaz, M. (2013). Preservation of precut white cheese by modified atmosphere packaging. International Journal of Dairy Technology, Vol. 66(4), 576-586.

Korhonen HJ (2009).Bioactive Components in Bovine Milk. En: Bioactive Components inMilk and Dairy Products, pág. 13-42 (Ed Y. W. Park), Wiley-Blackwell, Oxford, ReinoUnido. 
Kruger, C.L \& Mann, S.W. (2003) Safety evaluation of functional ingredients. Food and Chemical Toxicology 41, pp. 793-805.

Küçüköner, E. y Haque, Z.U. (2003). Physico-chemical and rheological properties of full fat and low fat Edam cheeses. Eur Food Res. Technol., pp.217:281286.

Kuo, M.-I. y Gunasekaran, S. (2009). Effect of freezing and frozen storage on microstructure of Mozzarella and pizza cheeses. LWT, Food Science and Technology, 42, 9-16.

Lairon, D.; Play, B. \& Jourdheuil-Rahmani, D. (2007) Digestible and indigestible carbohydrates: interactions with postprandial lipid metabolism. Journal of Nutrition Biochemistry 18, pp. 217-27

Laguna, L.; Farrell, G.; Bryant, M.; Morina, A. y Sarkar, A. (2017). Relating rheology and tribology of commercial dairy colloids to sensory perception. Food Funct., 8, 563-573.

LAS AF Lite (Leica Application Suite Advanced Fluorecence Lite), Version 2.2.0 builds 4758. Copyright (C) 2005-2009, Leica Microsystems CNS, GmbH, Alemania

Lattimer, J. \&Haub, M. (2010) Effects of dietary fiber and its components on metabolic health. Nutrients 2, pp. 1266-1289.

Lawrence, R.C.; Creamer, L.K. \& Gilles, J., (1987) Texture development during cheese ripening. Journal of Dairy Science, 70, pp. 1748-1760.

Li, J., y D. G. Dalgleish (2006). Controlled proteolysis and the properties of milk gels. J. Agric. Food Chem. 54:4687-4695.

Liu, X.T.; Zhang, H.; Wang, F.; Luo, J.; Guo, H.Y. y Ren, F.Z. (2014). Rheological and structural properties of differently acidified and renneted milk gels. Journal of Dairy Science, 97, 3292-3299.

Lodaite, K.; Stergren, K.O.G.; Paulsson, M. y Dejmek, P. (2000). Onedimensional syneresis of rennet-induced gels.International Dairy Journal 10,829-834.

Loewenstein, M. \& Gould, I.A. (1954) Journal Dairy Science 37, pp. 664.

Lopes da Silva, J. A. y Rao, M.A. (2007). Rheological Behavior of Food Gels. In: Rao, M.A. (Ed.), Rheology of Fluid and Semisolid Foods: Principles and Applications (2da ed.). Springer, Ney York, USA.

Lopez, C. (2005). Focus on the supramolecular structure of milk fatin dairy products.Reproduction Nutrition Development, 45, 497-511.

Lopez, C.; Camier, B.; Gassi J.-I. (2007). Development of the milk fat microstructure during the manufacture and ripening of Emmental cheese observed by confocal laser scanning microscopy. International Dairy Journal, 17, 235-247. 
Lu, R. \& Abbott, J.A. (2004) Capítulo 5: Force/deformation techniques for measuring texture en Texture in food Volume 2: Solid foods. Editor, David Kilcast. Editorial Boca Raton, Boston, New York, Washington, DC.

Lu, Y.; Shirashoji, N. \& Lucey, J.A. (2008) Effects of pH on the Textural Properties and Meltability of Pasteurized Process Cheese Made with Different Types of Emulsifying Salts. Journal of Food Science Vol. 73, Nr. 8, pp. 363-369.

Lück, H. (1977). Preservation of cheese and perishable dairy products by freezing. South African Journal of Dairy Technology, 9, 127-133.

Lucey, J.A.; Tamehana, M.; Singh, H.; Munro, P.A. (2000). Rheological properties of milk gels formed by a combination of rennet and glucono- $\delta$-lactone. Journal of Dairy Research, 67, 415-427.

Lucey, J.A.; Tamehana, M.; Singh, H.; Munro, P.A. (2001). Effect of heat treatment on the physical properties of milk gels made with both rennet and acid. International Dairy Journal, 11, 559-565.

Lutz, R.; Aserin A.; Portnoy Y.; Gotlieb, M. \&Garti, N. (2009) On the confocal images and the rheology of whey protein isolated and modified proteins associated complex. Coloids and Surfaces. B, Biointerfaces, 69, pp. 43-50.

Macku, I.; Bunka, F.; Pavlínek, V.; Leciánová, P. \& Hrabe, J. (2008) The effect of pectin concentration on viscoelastic and sensory properties of processed cheese. International Journal of Food Science and Technology, 43, 1663-1670.

Madrid, A.; Gómez Pastrana, J.; Santiago, F.J. \& Madrid, M. (1994) Refrigeración, congelación y envasado de los alimentos. Madrid Vicente A. ediciones.

Man, C.; Hicea, S. \&Ciupe, M. (2009) Data Regarding the Nutritional, Functional and Sensory Quality of Bio Milk. Bulletin UASVM Animal Science and Biotechnologies, pp.66 (1-2).

Marti, A.; Garcia, A.; Molina, P \&Diaz, J.R. (2000) Relación entre el rendimiento quesero y la composición de la leche de oveja de raza manchega a lo largo de la lactación. Producción Ovina XXV: Comunicación 6

Martínez-Tome, M., Murcia, M. A.; Frega, N.; Ruggieri, S.; J, A. M.; Roses, F.; y Parras, P. (2004). Evaluation of Antioxidant Capacity of Cereal Brans. J. Agric. Food Chem. 2004, 52, 4690-4699.

Mateo, M.J.; Everard, C.D.; Fagan, C.C.; O’Donnell, C.P.; Castillo, M.; Payne, F.A. \& O'Callaghan D.J. (2009) Effect of milk fat concentration and gel firmness on syneresis during curd stirring in cheese-making. International Dairy Journal 19, pp. 264-268.

McCrickerd, K. y Forde, C.G. (2016). Sensory influences on food intake control: moving beyond palatability. Obesity reviews, 17, 18-29.

Meilgaard, M. M., Civille, G. V. \& Carr, T. (1999) Descriptive analysis techniques en Sensory evaluation techniques, 3rd ed. Editorial: Boca Raton, Florida: CRC Press, pp. 173-183 
Menezes, E. W. d., Grande, F., Bistriche Giuntini, E., do Vale Cardoso Lopes, T., Tanasov Dan, M. C., Bernardino Ramos do Prado, S., y col. (2016). Impact of dietary fiber energy on the calculation of food total energy value in the Brazilian Food Composition Database. Food Chemistry, 193, 128-133.

Meullenet, J.F.C.; Carpenter, J.A.; Lyon B.G. \& Lyon, C.E. (1997) Bicyclical instrument for assessing texture profile parameters and its relationship to sensory evaluation of texture. Journal of Texture Studies, 28, pp. 101-118.

Mezzenga, R.; Schurtenberger, P.; Burbidge, A. \& Michel, M. (2005). Understanding foods as soft materials. Nature Materials, 4, 729-740.

Molist, F.; de Segura, A.G.; Gasa, J.; Hermes, R.G.; Manzanilla, E.G. \& Anguita, M. (2009) Effects of the insoluble and soluble dietary fibre on the physicochemical properties of digest and the microbial activity in early weaned piglets. Animal Feed Science and Technology 149(3-4), pp. 346-353.

Montesinos-Herrero, C.; Cottell, D. C.; O'Riordan, E. D. y O'Sullivan, M. (2006). Partial replacement of fat by functional fibre in imitation cheese: Effects on rheology and microstructure. International Dairy Journal, 16, pp. 910-919.

Mortensen, G.; Sørensen, J. y Stapelfeldt, H. (2002). Effect of light and oxygen transmission characteristics of packaging materials on photo-oxidative quality changes in semi-hard Havarti cheeses. Packaging Technology and Science, 15, 121-127.

Mudannayake D. C.; Wimalasiri,K. M.S.; Silva, K. F. S .T.; and Ajlouni, S. (2015). Comparison of Properties of New Sources of Partially Purified Inulin to Those of Commercially Pure Chicory Inulin. Journal of Food Science, Vol. 80 (5), C950C960.

Muir, D.D. (1984). Reviews of the progress of dairy science: frozen concentrated milk. Journal of Dairy Research, 51, 930-938.

Mulder, H., \& Walstra, P. (1974). In the milk fat globule.Wageningen, TheNetherlands: Center for Agricultural Publishing and Documentation.

Muzzarelli, R. A. A. (1996) Chitosan-based dietary foods. Carbohydrate Polymers, 29, pp.309-316.

Nielsen Company (2015). Global Health and Wellness Report. https://www.nielsen.com/content/dam/nielsenglobal/eu/nielseninsights/pdfs/Nielsen $\% 2$ 0Global\%20Health\%20and\%20Wellness\%20Report\%20-\%20January\%202015.pdf

Nielsen, S. Suzanne (Ed.); Food Analysis Laboratory Manual; Kluwer Academic/Plenum Publishers, New York, 2003

Nolan, E.J., Holsinger, V.H. y Shieh, J.J. (1989). Dynamic rheological properties of natural and imitation mozzarella cheese. Journal of Texture Studies, 20, 179-189.

Oberg, G.J.; Merrill, R.K.; Brown, R.J. y Richardson, G.H. (1992). Effects of freezing, thawing, and shredding on low-moisture, part-skim mozzarella cheese. Journal of Dairy Science, 75, 1161-1166. 
O'Brien, N.M. and O'Connor, T.P. (2011). Milk Lipids: Lipid Oxidation. In: Encyclopedia of Dairy Science, 2nd Edition. J.W. Fuquay, P.F. Fox and P.L.H. McSweeney Editors. Elsevier Publishers, London. Pages 716-720.

O'Connor T.P., O'Brien N.M. (2006). Lipid Oxidation. In Fox PF, McSweeney PLH, editors. Advanced dairy chemistry: Volume 2: Lipids. New York: Springer. p 557-600.

Olmedilla-Alonso, B.; Nova-Rebato, E.; García-González, N.; MartínDiana, A.-B.; Fontecha, J.; Delgado, D.; Gredilla, A.-E.; Bueno, F. y AsensioVegas, C. (2017). Effect of ewe's (semi-skimmed and whole) and cow's milk yogurt consumption on the lipid profile of control subjects: a crossover study. Food \& Nutrition Research, 61, article 1391669.

OMS/OPS (2007). Reducción del consumo de sal en la población: informe de un foro y una reunión técnica de la Organización Mundial de la Salud (OMS), 5-7 de octubre del 2006, París (Francia). Editorial: Organización Mundial de la Salud, Ginebra, Suiza.

Ong, L.; Dagastine, R.R.; Kentish, S.E. y Gras, S.L. (2010). The effect of milk processing on the microstructure of the milk fat globule and rennet induced gel observed using confocal laser scanning microscopy. Journal of Food Science E: Food Engineering and Physical Properties, Vol. 75(3), E135-E145.

Ong, L.; Dagastine, R.; Kentish, S. \& Gras, S. (2011) Microstructure of milk gel and cheese curd observed using cryo scanning electron microscopy and confocal microscopy. LWT - Food Science and Technology 44, pp. 1291-1302.

Okpala, C.O.R.; Piggott, J.R. y Schaschke, C.J. (2010) Influence of highpressure processing (HPP) on physico-chemical properties of fresh cheese. Innovative Food Science and Emerging Technologies 11, pp. 61-67.

Olagnero G., Abad A., Bendersky S., Carolina G., Granzella L. y Montonati M., (2007) Alimentos funcionales: fibra, prebióticos, probióticos y simbióticos. DIAETA, 2007, Vol. 25, No 121, 20-33.

Olds Schneeman, B. (1986) Dietary Fiber: Physical and Chemical Properties, Methods of Analysis, and Physiological Effects. Food technology, pp. 104-110.

Ottogalli, G. y Rondinini, G. (1974). Effets de la congelation sur des microrganismes qui se trouvent dans les produits laitiers. Revue Generale du Froid, 5, $443-451$.

Pandya, A.J. y Ghodke, K.M. (2006) Goat and sheep milk products other than cheeses and yoghurt. Small Ruminant Research, 68, pp. 193-206.

Park A.R. y Oh D.K. (2010). Galacto-oligosaccharide production using microbial $\beta$-galactosidase: Current state and perspectives. Applied Microbiology and Biotechnology, 85(5) 1279-1286.

Park, Y.W. (2001). Proteolysis and Lipolysis of Goat Milk Cheese. J. Dairy Sci. 84 (E. Suppl.): E84-E92 
Park, Y.W. (2013). Effect of 5 years long-term frozen storage on sensory quality of Monterey Jack caprine milk cheese. Small Ruminant Research, 109, 136-140.

Park, Y.W. y Drake, M.A. (2005). Effect of 3 months frozen-storage on organic acid contents and sensory properties, and their correlations in soft goat milk cheese. Small Ruminant Research, 58, 291-298.

Park, Y.W.; Kalantari, A. y Frank, J.F. (2004). Changes in the microflora of commercial soft goat milk cheese during refrigerated and frozen-storage. Small Ruminant Research, 53, 61-66.

Park, Y.W. y Lee, J.H. (2006). Effect of freezing on organic acid contents and lipolytic index of plain soft and Monterey Jack goat milk cheeses. Small Ruminant Research, 63, 58-65.

Park, Y.W.; Pariza, M.W. (2007). Mechanisms of body fat modulation by conjugated linoleic acid (CLA). Food Res Int, 40:311-23.

Park, Y.W; Júarez, M.; Ramos, M. \& Haenlein G.F.W. (2007) Physicochemical characteristics of goat and sheep milk. Small Ruminant Research, 68, pp.88113.

Pegg, R. B. (2001). Lipid Oxidation/ Stability. En: Current Protocols in Food Analytical Chemistry. Wiley Online Library, John Wiley \& Sons, Inc.

Pettersen, M. K.; Eiea, T.; Nilsson, N. (2005). Oxidative stability of cream cheese stored in thermoformed trays as affected by packaging material, drawing depth and light. International Dairy Journal, 15, 355-362.

Phillips, G.O. y Cui, S.W. (2011). An introduction: Evolution and finalization of the regulatory definition of dietary. Food Hydrocolloid 25, pp. 139-143.

Phillips, M.C. (2005). Mechanisms of cholesterol-lowering effects of dietary insoluble fibres: Relationships with intestinal and hepatic cholesterol parameters. British Journal of Nutrition 94, pp. 331-337.

Pérez-Jiménez, J.; Serrano, J.; Tabernero, M; Arranz, S.; Díaz-Rubio, M. E.; García-Diz, L.; Goñi, I.; Saura-Calixto, F. (2009). Bioavailability of Phenolic Antioxidants Associated with Dietary Fiber: Plasma Antioxidant Capacity After Acute and Long-Term Intake in Humans. Plant Foods Hum Nutr, 64:102-107.

Petkova, N.;Vrancheva, R.; Mihaylova, D.; Ivanov I.; Pavlov, A. y Denev, P. (2015). Antioxidant activity and fructan content in root extracts from elecampane (Inulahelenium L.). J. BioSci. Biotechnol., 4(1): 101-107.

Pino, A., (2005). Utilización de enzimas coagulantes del cardo Cynara cardunculus en la fabricación de queso de cabra. Ph.D. thesis, Universidad de Córdoba, Córdoba, España.

Pomeranz Y. y Meloan C.E. (1984). Food Analysis Theory and Practice. 3era Edición; Chapman \& Hall, USA. 
Posati, L.P. y Orr, M.L. (1976).Composition of Foods, Dairy and Egg Products. USDA-ARS, Consumer \& Food Economics Inst. Publ., Washington, D.C., Agr. Handbook, No. 8-1, pp. 77-109.

Prados, F.; Pino, A.; Rincón, F.; Vioque, M.; Fernández-Salguero, J. (2006). Influence of the frozen storage on some characteristics of ripened Manchego-type cheese manufactured with a powdered vegetable coagulant and rennet. Food Chemistry, 95, 677-682.

Prandini, A.; Sigolo, S. y Piva, G. (2011). A comparative study of fat acid composition and CLA concentration in commercial cheeses. Journal of Food Composition and Analysis 24, 55-61.

Puupponen-Pimia, R.; Aura, A.M.; Oksman-Caldentey, K.M.; Myllarinen, P.; Saarela, M.; Mattila-Sandholm, T. \&Poutanen, K. (2002) Development of functional ingredients for gut health. Trends in Food Science \& Technology 13, 3-11.

Raghavendra, S. N., RamachandraSwamy, S. R., Rastogi, N. K., Raghavarao, K. S. M. S., Kumar, S., \&Tharanathan R. N. (2006). Grinding characteristics and hydration properties of coconut residue: A source of dietary fiber. Journal of Food Engineering, 72, 281-286.

Ramaswamy, H. S.; Singh, A.; y Sharma, M. (2015). Back extrusion rheology for evaluating the transitional effects of high pressure processing of egg components. Journal of Texture Studies, 46, 34-45.

Ramos, M. y Juarez, M. (2011). Sheep Milk en Encyclopedia of Dairy Sciences (Second Edition), 494-502.

Rasmussen, N.; Andersen, J.H.; Jespersen, H.; Mouritsen, O.G. y Ditzel, H.J. (2010). Effect of free fatty acids and lysolipids on cellular uptake of doxorubicin in human breast cancer cell lines. Anticancer Drugs, 21, 674-677.

Rao, M.A. y Cooley, H.J. (1992). Rheological behavior of tomato pastes in steady and dynamic shear. Journal of Texture Studies, 23, 415-425.

Research \& Markets 2013 Global Functional Food and Nutraceuticals Market (2013 -2018). http://www.researchandmarkets.com/research/m9qvsw/global_functional.

Ribero, G.G.; Rubiolo, A.C. y Zorrilla, S.E. (2009). Microstructure of Mozzarella cheese as affected by the immersion freezing in $\mathrm{NaCl}$ solutions and by the frozen storage. Journal of Food Engineering, 91, 516-520.

Rinaldi, V. \& Mingo Arechederra, T. (2001) Alimentos funcionales II: La industria Nacional, Enfasis Alimentación n ${ }^{\circ} 4$, pp. 46-77.

Robertson, G. L. (2006). Food Packaging: Principles and Practice. 2nd ed. CRC Press, Boca Raton, FL.

Rodrıguez, R.; Jiménez, A.; Fernández-Bolaños, J.; Guillén, R. \& Heredia A. (2006) Dietary fibre from vegetable products as source of functional ingredients. Trends in Food Science \& Technology 17, pp. 3-15. 
Roefs, S.P.F.M.; De Groot-Mostert, A.E.A. y Van Vliet T. (1990). Structure of Acid Casein Gels 1. Formation and Model of Gel Network. Colloids and Surfaces, 50, 141-159.

Rowney, M. K.; Roupas, P.; Hickey, M. W. \& Everett, D. W. (2004). Saltinduced structural changes in 1-day old Mozzarella cheese and the impact upon free oil formation. International Dairy Journal, 14, 809-816.

Salvador, A. \& Fiszman, S.M. (1998) Textural characteristics and dynamic oscillatory rheology of maduration of milk gelatigels with low acidity. Journal Dairy Sci, 81, pp.1525-1531.

Salvatore, E., A. Pirisi, y M. Corredig (2011). Gelation properties of casein micelles during combined renneting and bacterial fermentation: Effect of concentration by ultrafiltration. Int. Dairy J. 21:848-856.

Sandra, S.; Ho, M.; Alexander, M. y Corredig M. (2012). Effect of soluble calcium on the renneting properties of casein micelles as measured by rheology and diffusing wave spectroscopy. Journal of Dairy Science, 95, 75-82.

Saura-Calixto, F. (1998). Antioxidant Dietary Fiber Product: A New Concept and a PotentialFood Ingredient. J. Agric. FoodChem. 1998, 46, 4303-4306.

Schulz-Collins, D., ySenge, B. (2004).Acid and acid/rennet curd cheeses. Part A: quark, cream cheese and related varieties. In P. F. Fox, P. L. H. McSweeney, T. M. Cogan, \& T. P. Guinee (Eds.), Cheese: Chemistry, physics and microbiology (3rd ed.). Major cheese groups, Vol. 2 (pp. 300e328) London, UK: Elsevier Academic Press.

Seisa, D.; G. Osthoff; C. Hugo; A. Hugo; C. Bothma; J. Van der Merwe (2004). The effect of low-dose gamma irradiation and temperature on the microbiological and chemical changes during ripening of Cheddar cheese. Radiation Physics and Chemistry 69 (2004) 419-431.

Sen, D.C. y Gupta, S.K. (1987). Effects of freezing and thawing on the sensory qualities of dairy products. Indian Dairyman, 39, 231-235.

Sendra, E., Kuri, V., Fernández-López, J., Sayas-Barberá, E., Navarro, C. y Pérez-Alvarez, J. A. (2010). Viscoelastic properties of orange fiber enriched yogurt as a function of fiber dose, size and thermal treatment. LWT Food Science and Technology, 43, 708-714.

Shahidi, F. (2004) Functional foods: their role in health promotion and disease prevention. Journal of Food Science, 69, pp. R146-R149. 68,70

Shimp, L.A. (1985) Process cheese principles. Food Technol 39(May):63-4, 66,

Sieber R. (2001) Zusammensetzung von Milch und MilchproduktenschweizerischerHerkunft, FAMI information 1-23, available at http://www.db-alp.admin.ch/de/publikationen/docs/pub_Sieb

Silva, R.F. (1996) Use of inulin as a natural texture modifier. Cereal Foods World, v.41, n.10, pp.792-794. 
Simat, V.; Bogdanović, T.; Poljak, V.y Petričević, S. (2015). Changes in fatty acid composition, atherogenic and thrombogenic health lipid indices and lipid stability of bogue (Boops boops Linnaeus, 1758) during storage on ice: Effect of fish farming activities. Journal of Food Composition and Analysis, 40, 120-125.

Skeaff, C. M., Williscroft, K., Mann, J. \& Chisholm, A. (2004).Replacing cows' with sheep's dairy fat lowers plasma cholesterol concentration in participants consuming dairy fat-rich diets. European Journal of Clinical Nutrition, 58, 250-257.

Sluijs, I.; van der Schouw, Y.T.; van der A, D.L.; Spijkerman, A.M.; Hu, F.B.; Grobbee, D.E. \& Beulens, J.W. (2010) Carbohydrate quantity and quality and risk of type 2 diabetes in the European Prospective Investigation into Cancer and Nutrition-Netherlands (EPIC-NL) study. American Journal of ClinicalNutrition 92, pp. 905-911.

Sosa, J.; Althaus, R.; Scaglione, L.; Roldan, V.; \& Moreira, E. (2001) Composición química y mineral de la leche de ovejas. Corriedale y Hampshire down. Revista FAVE: 15 (2), pp. 7-12.

Southgate, D.A.T. (1976). Determination of Food Carbohydrates. Applied Science Publishers, London.

Southgate, D.A.T. (1982). Definitions and terminology of dietary fiber. Dietary Fiber in Health and Disease. Plenum Press, N. Y.

Spence, J.T. (2006) Challenges related to the composition of functional foods. Journal of Food Composition and Analysis 19, S4-S6.

Steffe, J. F. (1996). Viscoelasticity. Capítulo 5 en: Rheological Methods in Food Process Engineering. Michigan, East Lansing: Freeman Press.

Suárez, V.H. \& Busetti, M.R. (1999) Lechería ovina y aptitud lechera de la raza Pampinta. Boletín de divulgación técnica $\mathrm{N}^{\mathrm{o}}$ 63. 62p.

Systat ${ }^{\circledR} 12$ Statistics-I. Copyright 2007 by Systat Software, Inc. Chicago, IL, USA.

Tardy, A.-L.; Morio, B.; Chardigny, J.-M. y Malpuech-Brugère, C. (2011). Ruminant and industrial sources of trans-fat and cardiovascular and diabetic diseases. Nutrition Research Reviews, 24, 111-117.

Talukder P., Talapatra S., Ghoshal N., SenRaychaudhuri S., (2016). Antioxidant activity and HPLC analysis of phenolic compounds during in vitro callus culture of Plantago ovate Forsk and effect of exogenous additives on accumulation of phenolic compounds. J Sci Food Agric., 96(1),232-244.

Tawongsa, W. y Abdelmoula, A. (2014). Rheological categorization and quality of Large-scale marketable mayonnaise using back extrusion. Afr. J. Food Sci., 2, 59-64.

Tejada, L., Gómez, R., Vioque, M., Sánchez, E., Mata, C. y FernándezSalguero, J. (2000). Effect of freezing and frozen storage on the sensorial 
characteristics of Los Pedroches, a Spanish ewe cheese. Journal of Sensory Studies, 15, 251-262.

Tejada, L., Sánchez, E., Gómez, R., Vioque, M. y Fernández-Salguero, J. (2002). Effect of freezing and frozen storage on chemical and microbiological characteristics in sheep milk cheese. Journal of Food Science, 67, 126-129.

Thebaudin, J.Y; Lefebvre, A.C.; Harrington, M. \& Bourgeois, C.M. (1997) Dietary Fibres: Nutritional and technological interest. Trends in Food Science \& Technology vol.8, pp. 41-48.

Theuwissen, E.; y Mensink, R.P. (2008). Water-soluble dietary fibers and cardiovascular disease. Physiology \& Behavior, 94, 285-292.

Tranchant, C.C.; Dalgleish, D.G. \& Hill, A.R. (2001). Different coagulation behaviour of bacteriologically acidified and renneted milk: the importance of finetuning acid production and rennet action. International Dairy Journal, 11, 483-494.

Tungland, B.C. \& Meyer, D.(2002) Nondigestibleoligo and polysaccharides (dietary fibre): their physiology and role in human health and food. Comprehensive Reviews in Food Science and Food Safety 1(3), pp. 90-109.

Tunick, M. H. (2000). Symposium: dairy products rheology. Rheology of Dairy Foods that Gel, Stretch, and Fracture. J. Dairy Sci., 83, 1892-1898.

Ünalan, İ. U., Arcan, I., Korel, F. y Yemenicioğlu, A. (2013). Application of active zein-based films with controlled release properties to control Listeria monocytogenes growth and lipid oxidation in fresh Kashar cheese. Innovative Food Science \& Emerging Technologies, Vol. 20, 208-214

Van Aken, G. A. y Visser, K. A. (2000). Firmness and crystallization of milk fat in relation to processing conditions. Journal of Dairy Science, 83:1919-1932.

Van Hekken, D.L., Tunick, M.H. y Park, Y.W. (2005). Effect of Frozen Storage on the Proteolytic and Rheological Properties of Soft Caprine Milk Cheese. Journal of Dairy Science, 88, 1966-1972.

Van Den Berg, L. (1960) Changes in pH of milk during freezing and frozen. National Research Council, Ottawa, Canada, N.R.C. No. 6055, 26-31.

Van Vliet, T. (1991). Spreadability of (low-fat) spreads; some rheological aspects. Indian Food Industry Mag, 2, 36-39.

Vasconcellos, J. A. (2001) Los Alimentos del futuro. La alimentación Latinoamericana, 231, 11-21.

Veisseyre, R. (1980). Lactología técnica (2nd ed.). Acribia, S.A.: Zaragoza, España, 527 p.

Vercelino Alves, R. M.; Van Denderb, A. G. F.; Jaime, S. B. M.; Moreno, I; Pereira, B. C. (2007). Effect of light and packages on stability of spreadable processed cheese. International Dairy Journal, 17, 365-373. 
Visioli, F. y Strata, A. (2014). Milk, dairy products, and their functional effects in humans: a narrative review of recent evidence. Adv in Nutrition, 5, 131-143.

Voisey, P.W., y Nonnecke, I.L. (1972). Measurement of pea tenderness. IV. Development and evaluation of the test cell. J. Texture Stud. 3, 459-477.

Voutsinas, L.P., Katsiari, M.C., Pappas, C.P. y Mallatou, H. (1995). Production of brined soft cheese from frozen ultrafiltered sheep milk. 2. Compositional, physicochemical, microbiological and organoleptic properties of cheese. Food Chemistry, 52, 235-247.

Walther, B.; Schmid, A.; Sieber, R. \&Wehrmüller, K. (2008) Cheese in nutrition and health. Dairy Sci. Technol. INRA, EDP Sciences, DOI: 10.1051/dst: 2008012

Wang, Z.Q.; Zuberi, A.R.; Zhang, X.H.; Macgowan, J.; Qin, J. \& Ye, X. (2007). Effects of dietary fibers on weight gain, carbohydrate metabolism, and gastric ghrelin gene expression in mice fed a high-fat diet. Metabolism 56, pp. 1635-1642.

Wang, T; Lee, H.G. 2015. Advances in research on cis-9, trans-11 conjugated linoleic acid: a major functional conjugated linoleic acid isomer. Critical Review in Food Science and Nutrition, 55,720-31.

Webb, B. H. y Arbuckle, W. S. (1977). Freezing of Dairy Products. En: Fundamentals of Food Freezing. Springer, Dordrecht (Alemania), pp 357-395.

WHO: World Health Organization (2003). Diet, nutrition and the prevention of chronic diseases. WHO technical report series 916. Geneva

Wu, C.F.J. \& Hamada, M. (2000) Experiments: Planning Analysis and Parameter Design Optimization. John Wiley \& Sons, Inc. U.K.

Zehren, V.L. \&Nusbaum, D.D. (2000) Processed cheese. $2^{\text {nd }}$, Ed. Madison, Wis. Editorial Cheese reporter publishing co. Inc.

Zhang, R.H.; MustafaA.F.; Ng-Kwai-Hang-K.F.; Zhao X. (2006). Effects of freezing on composition and fatty acid profilesof sheep milk and cheese. Small Ruminant Research 64 (2006) 203-210. 